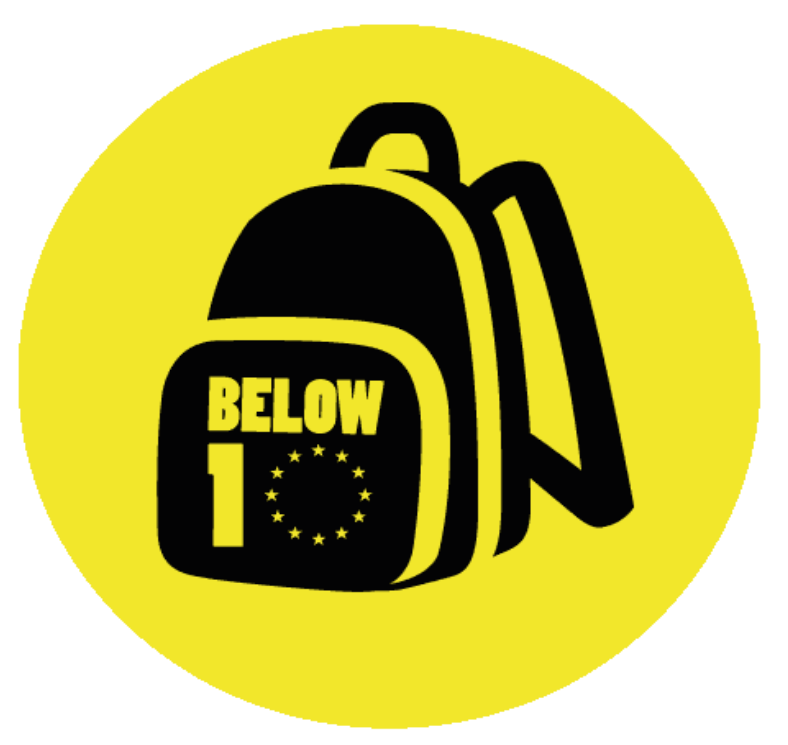

\title{
STORIES OF YOUNG DROPOUTS: A SOCIAL SURVEY OF SUCCESS AND FAILURE
}

\author{
BELOW 10 PROJECT \\ Intellectual Output 1 Report \\ Final Version
}

Project 2016-1-IT02-KA201-024125

The European Commission support for the production of this publication does not constitute an endorsement of the contents which reflects the views only of the authors, and the Commission cannot be held responsible for any use which may be made of the information contained therein.

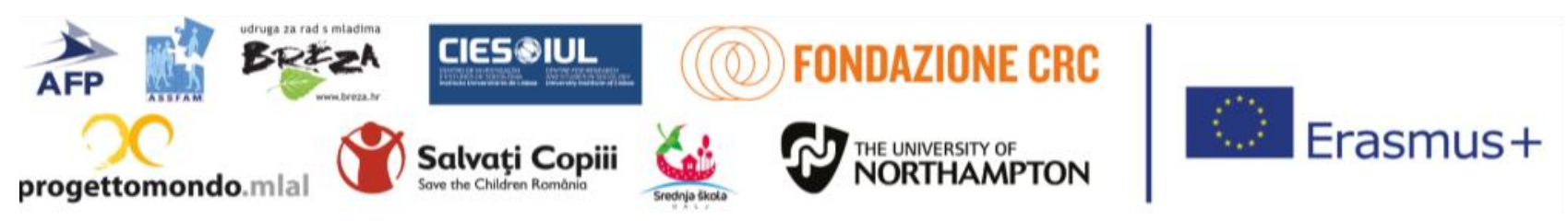




\section{Authors}

Sandra Mateus (coord.), Filipa Pinho, Patrícia Amaral, Susana Murteira (CIES, ISCTE-IUL)

\section{CIESOIUL}

CENTRO DE INVESTIGAÇĀO

Instituto Universitário de Lisboa

\section{Contributors}

Ivana Bertić Bulić (Srednja škola Dalj, Croatia)

Ivana Šibalić (Udruga za rad s mladima Breza, Croatia)

Magali Ciais \& Fatma Fall (ASSFAM - Groupe SOS Solidarités, France)

Attilio Orecchio, Marina Lovato \& Nadia Simeoni (Progettomondo.mlal, Italy)

Ingrid Brizio, Raffaella Gramaglia \& Sara Comba (AFP, Italy)

Stefania Avetta \& Irene Miletto (Fondazione CRC, Italy)

Cristina Devecchi (University of Northampton)

Andreea Hagiu \& Andra Stoian (Save the Children, Romania)

\section{Project Coordinator}

Attilio Orecchio (Progettomondo.mlal, Italy)

This report is the Intellectual Output 1 of the Below 10 Project, led by CIES-ISCTE. It has been drafted by CIES-ISCTE and undertaken with the support of all the project partners for the purposes of the Below 10 project. The output was developed between 1.09.2016 and 31.03.2018.

\section{Creative Commons License}

\section{(c) (1) (9)}

This report is licensed under a Creative Commons Attribution-NonCommercial 4.0 International License (CC BY-NC 4.0)

\section{April 2018}




\section{TABLE OF CONTENTS}

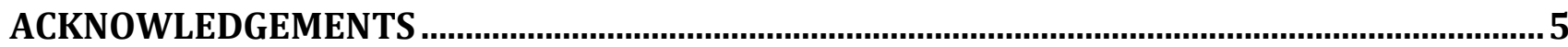

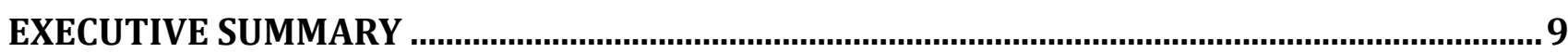

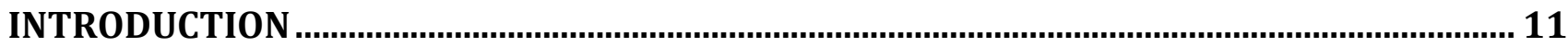

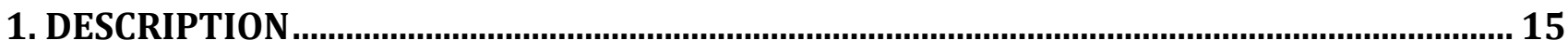

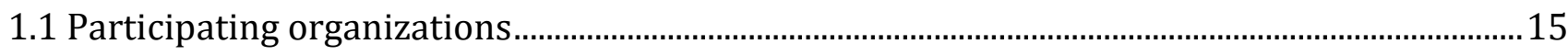

1.2 Objectives of the Intellectual Output 1 …................................................................................. 15

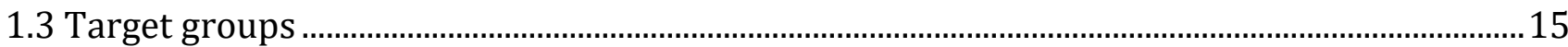

2 RESEARCH: AIMS AND METHODOLOGIES APPLIED …........................................................ 21

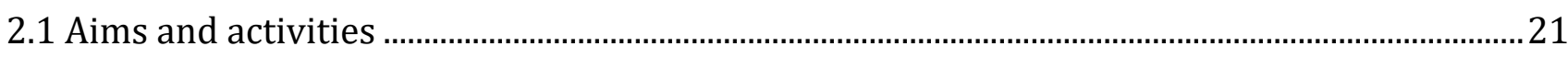

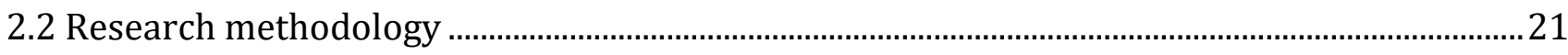

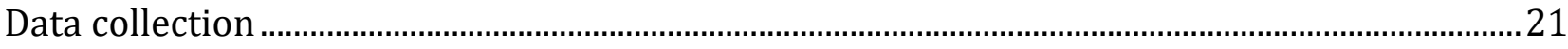

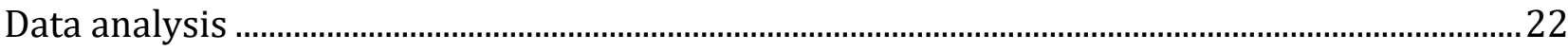

2.3 Participants: characterization of who were involved in the research ........................................24

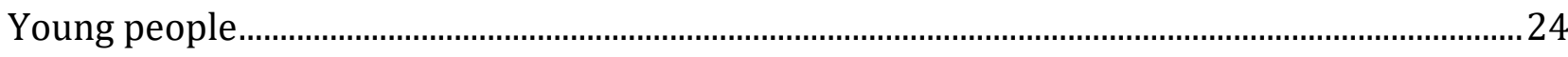

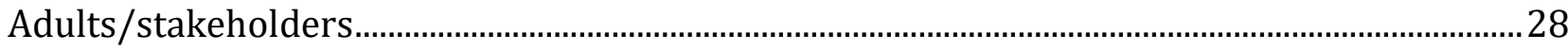

3. SCHOOL FAILURE AND EARLY SCHOOL LEAVING IN EUROPE............................................ 33

3.1 Contexts: situation of school failure and ESL in Europe and in each country............................33

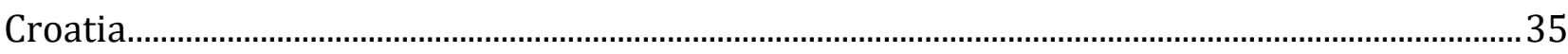

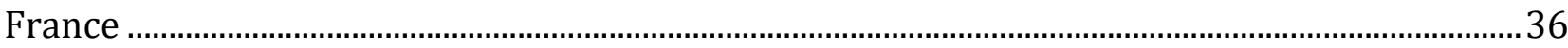

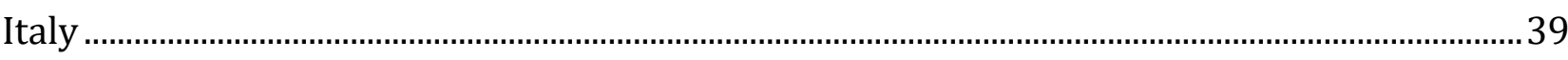

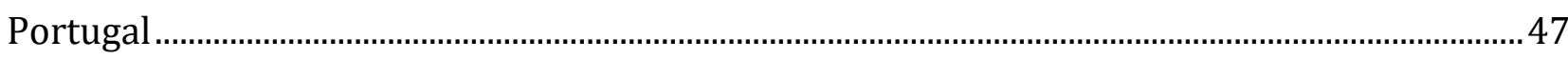

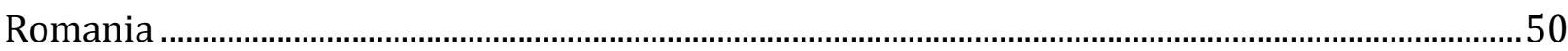

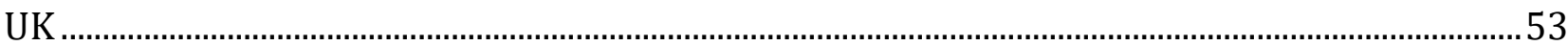

3.2 Local initiatives and practices....................................................................................................

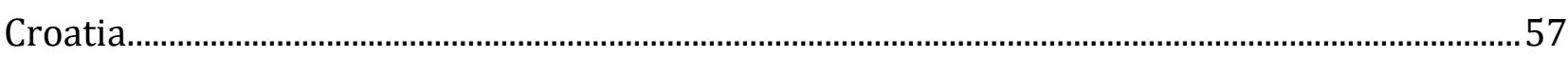

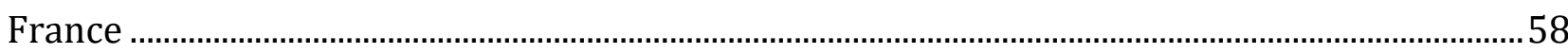

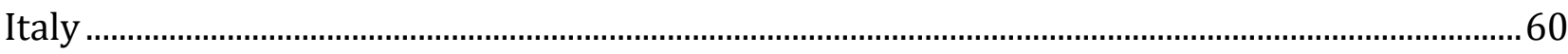

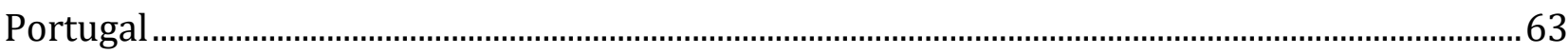

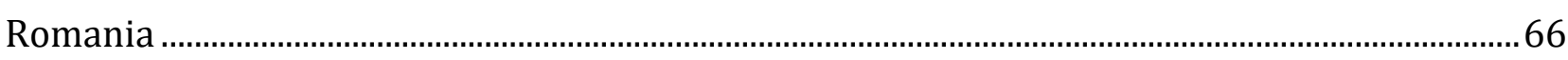

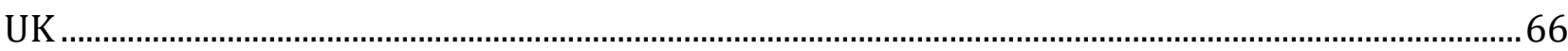

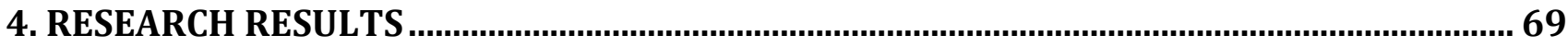

4.1 Key findings on school failure and ESL from the perspective of the youngsters.......................69

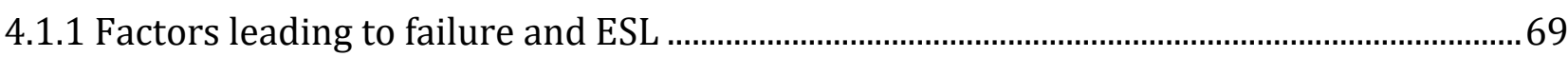

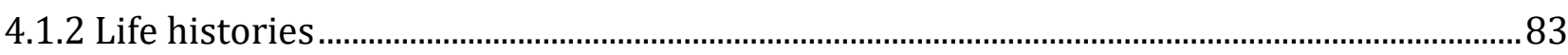

Early School Leavers not in employment, education or training (NEET) ......................................... 85

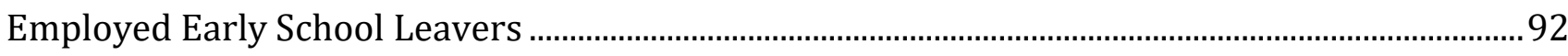


Young people at high risk of early school leaving .............................................................................. 102

Young people who have returned to school or training after ESL or suspending ......................... 108

Young people enrolled in education or vocational training ........................................................... 121

4.2 Key findings on school failure and ESL from the perspective of adults and stakeholders.. 129

4.2.1 Factors leading to failure and ESL ................................................................................... 130

5. IDEAS FOR ACTION: RECOMMENDATIONS FROM PARTICIPANTS ..................................149

6. REFLECTION AND LESSONS LEARNED ......................................................................161

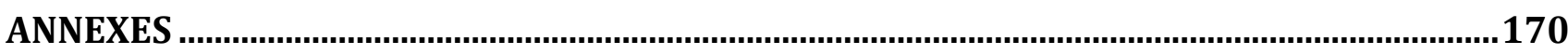

Annex 1 Template for semi-structured, in-depth interview with young people............................. 171

Annex 2 Template for focus group of young people....................................................................... 174

Annex 3 Template for focus group of actors and stakeholders....................................................... 175

Annex 4 Output 1 Final Report Template ...................................................................................... 177

Template A Short country and local report template (max. 4 pages)......................................... 179

Template B Stakeholders/adults report template (max. 3 pages).............................................. 181

Template C Youth report template (maximum 4 pages) ............................................................ 183

Template D Life histories (maximum 2 pages per box) ……………………………………….... 185 


\section{LIST OF TABLES}

Table 1.1 Number of participants per target group, methodology and territory- planned.18

Table 1.2 Number of participants in each target group and methodology - totals planned

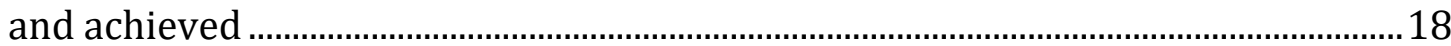

Table 1.3 Number of focus groups and interviews in each territory..........................................19

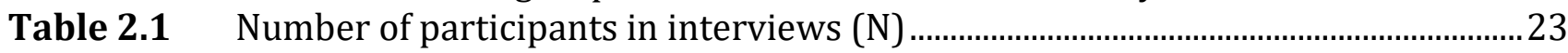

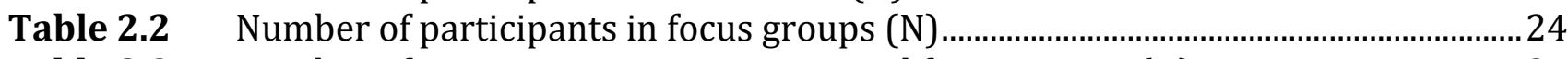

Table 2.3 Number of participants in interviews and focus groups (N) .................................... 24

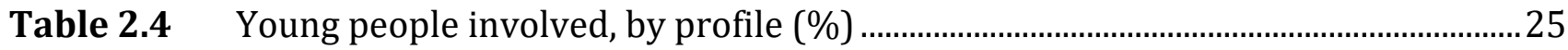

Table 2.5 Young people involved, by age (\%)

Table 2.6 Young people involved, by gender (\%) ......................................................................26

Table 2.7 Young people involved, by highest level of education attained (\%) ........................27

Table 2.8 Young people involved, by migrant background (\%) ..................................................27

Table 2.9 Young people involved, by socioeconomic status (\%) ................................................28

Table 2.10 Young people involved, by health condition (\%) ........................................................28

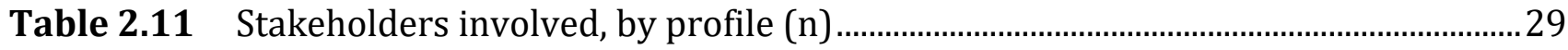

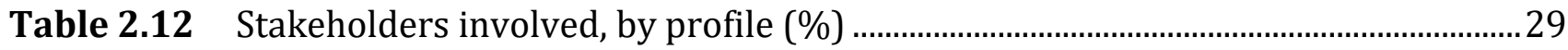

Table 2.13 Stakeholders involved, by gender (\%) ........................................................................ 30

Table 2.14 Stakeholders involved, by category of education and training practitioners (\%) 30

Table 2.15 Stakeholders involved, by category of non-school practitioners (\%) ......................31

Table 2.16 Stakeholders involved, by category of family members and others (\%) ................31

Table 3.1 Share of early leavers from education and training, Portugal, 2001-2011-2017 (\%

of population aged 18 to 24), by sex................................................................................... 48

Table 3.2 Share of early leavers from education and training, Portugal, 2011-2017 (\% of population aged 18 to 24), by sex and region.................................................................49

Table 3.3 Percentage of 16-17 years old not in education or training for the three LAs ......56

Table 4.1 Individual factors explaining disengagement and ESL (Youth)..................................70

Table 4.2 Family factors explaining disengagement and ESL (Youth)........................................74

Table 4.3 School factors explaining disengagement and ESL (Youth) .......................................78

Table 4.4 Community factors explaining disengagement and ESL (Youth)..............................82

Table 4.5 Characterization of participants in life stories, by sex, age, country and profile ..84

Table 4.6 Individual factors explaining disengagement and ESL (Stakeholders) .................132

Table 4.7 Family factors explaining disengagement and ESL (Stakeholders) ....................... 136

Table 4.8 School factors explaining disengagement and ESL (Stakeholders)....................... 142

Table 4.9 Community factors explaining disengagement and ESL (Stakeholders) .............. 147

Table 5.1 Young people's recommendations by country and category ................................... 154

Table 5.2 Stakeholders' recommendations by country and category ........................................ 156 


\section{LIST OF FIGURES}

Figure 3.1 Share of early leavers from education and training, EU 28, 2010-2017 (\% of

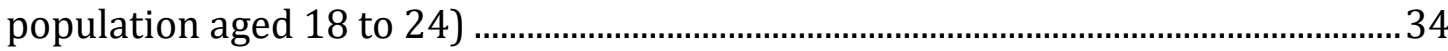

Figure 3.2 Share of early leavers from education and training, Croatia, 2010-2017 (\% of

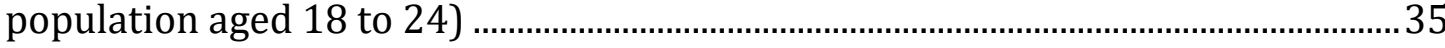

Figure 3.3 Share of early leavers from education and training, France, 2010-2017 (\% of

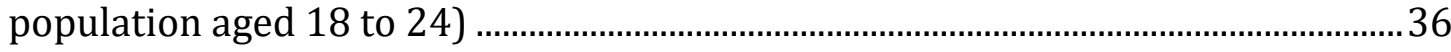

Figure 3.4 Share of early leavers from education and training, Italy, 2010-2017 (\% of

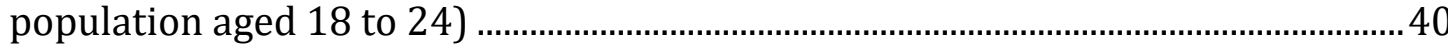

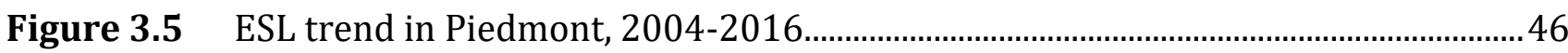

Figure 3.6 Share of early leavers from education and training, Portugal, 2010-2017 (\% of population aged 18 to 24$)$................................................................................................ 48

Figure 3.7 Share of early leavers from education and training, Romania, 2010-2017 (\% of population aged 18 to 24 )

Figure 3.8 Share of early leavers from education and training, UK, 2010-2017 (\% of population aged 18 to 24 )

Figure 3.9 Participants in education and WBL (work based learning) by academic age, England 54

Figure 3.10 Proportion NEET by academic age, England 55 


\section{ACKNOWLEDGEMENTS}

We wish to express appreciation to all representatives of the institutions that participated in the debate about school success, failure and leaving, in all countries and territories involved in the research. We also want to thank to all institutions that were engaged in involving young participants in the interviews and focus groups. Last, but not least, we are very grateful for the life histories and trajectories the youngsters shared with us.

All the institutions that collaborated with the partners are sorted according to the alphabetical order of their countries and listed below.

Srednja škola Dalj, from Croatia, wishes to thank to: Municipality Erdut, Primary school Dalj, Primary school Bijelo Brdo, Technical high school Nikola Tesla Vukovar, LRA - local development agency Dalj, Youth Centre Dalj.

Udruga za rad s mladima Breza, from Croatia, wishes to thank to: City of Osijek, Osječkobaranjska County, Centre for social care CISOK (Osijek), Voluntary Centre Osijek, Faculty of Law - University Centre for social work (Zagreb), Youth network Croatia, Info centre for youth Osijek, Medical school Osijek, Primary school Fran Krsto Frankopan (Osijek), Vocatinal training Centre OBRIS (Osijek), Centre for social services KLASJE (Osijek).

Groupe SOS Solidarités - ASSFAM, from France, wishes to thank to: Town councils of the 18th and 19th arrondissement of Paris, Académie de Paris, Académie de Paris - MLDS (Mission de lutte contre le décrochage scolaire), Académie de Créteil - SAIO (Service Académique d'Information et d'Orientation), Direction départementale de la Cohésion Sociale (DDCS 75), Ecole de la 2ème chance de Paris (E2C Paris), Lycée Marcel Cachin, Collège Michelet, L'école pilote Alexandre Dumas de la Fondation Espérance Banlieues, Equipe de Développement Local (EDL) du 19ème arrondissement de Paris, Association de la Fondation Etudiante pour la Ville (AFEV), Educ'Hand, Entraide Scolaire Amicale (ESA), Association Génération Citoyenne du 19ème arrondissement (GCXIX), Solidascension, Association pour l'Education, l'Intégration et le Développement (AEID), Un Stage Et Après (USEA), Villeneuve Animation et Vie Urbaine (VAVU), Club de prévention spécialisée La Clairière, Energies Jeunes, Pôle emploi, Accueil Réussite Éducative Pelleport, Réseau école du Parti Communiste Français (PCF), Fédération des Conseils de Parents d'Elèves 94 (FCPE 94), Association des Parents d'Élèves de l'École Lucien de Hirsch, Syndicat National Unitaire des Instituteurs et Professeurs des écoles et PEGC (Snuipp 93). 
AFP and Fondazione CRC, from Italy, Cuneo, wish to thank to: 1) Schools involved in the research (APRO Formazione - Sede di Alba, Associazione CNOS-FAP Regione Piemonte - Sede di Fossano, Azienda Formazione Professionale s.c.a r.l. - Centro di Verzuolo e Cuneo, Centro di Formazione Professionale Cebano Monregalese di Mondovì e Ceva, Istituto Comprensivo 1 di Mondovì, Istituto Comprensivo A. M. Riberi di Caraglio, Istituto Comprensivo Corso Soleri di Cuneo, Istituto Comprensivo di Chiusa Pesio e Peveragno, Istituto Comprensivo Rosa Bianca di Saluzzo e Rete delle Scuole del Saluzzese, Istituto Istruzione Superiore "Cigna-Baruffi-Garelli" di Mondovì, Istituto Istruzione Superiore Denina-Pellico- Rivoira di Saluzzo e Verzuolo, Istituto di Istruzione Secondaria Superiore "Piera Cillario Ferrero" di Alba, Istituto Tecnico Commerciale "F. A. Bonelli" di Cuneo, Liceo Scientifico e Classico G. Peano e S. Pellico di Cuneo); 2) other stakeholders involved in focus groups: Regione Piemonte (Regional Government), Ministry of Education Universities and Research (Italy) - Territorial School Office (District of Cuneo), Direzione Integrata della Prevenzione e Promozione della Salute ASL CN1 di Cuneo, Consorzio Monviso Solidale, Cssm - Consorzio per I servizi socio-assistenziali del Monregalese, Emmanuele onlus - cooperative sociale, Orso. Società Cooperativa Sociale- Organizzazione per la ricreazione sociale, Paola Merlino, researcher, Roberta Santi, researcher, “Genitori Pro Handicap” Parents' Association, “Genitori DSA” Parents' Network, “Airone” Association (Manta), San Paolo's Parish, Cuneo - Aggregation Centre.

Progettomondo.mlal, from Italy, wishes to thank to: Comune di Villafranca di Verona Assessorato alle Politiche giovanili e Assessorato alle Politiche Sociali e per la Famiglia; Centro Provinciale per l'Istruzione degli Adulti; AULSS 9 - Azienda Unità Sanitaria Locale 9 - Veneto; Cooperativa Sociale Hermete; Liceo Scientifico Statale "Enrico Medi"; Istituto Statale di Istruzione Superiore "Carlo Anti"; Istituto Statale di Istruzione Superiore "Ettore Bolisani"; Centro di Formazione professionale Scaligera Formazione - sede "L. Tosoni”; Istituto Statale di Istruzione Superiore "Stefani Bentegodi"; Istituto statale comprensivo "Cavalchini- Moro".

CIES, ISCTE-IUL wishes to thank to: Agrupamento de Escolas das Mães d'Água; Câmara Municipal da Amadora; Casal Popular da Damaia; CPCJ-Amadora, Escola Profissional Gustave Eiffel; Equipa de Saúde Escolar; Escola Secundária D. João V; Escola Secundária Seomara da Costa Primo; Escola Superior de Educação de Lisboa; Escola Superior de Educação de Santarém; Moinho da Juventude; Instituto do Emprego e da Formação Profissional da Amadora; Observatório Permanente da Juventude; Orquestra Geração/Escola de Música do Conservatório Nacional; 
Programa Nacional de Promoção do Sucesso Escolar; Programa Operacional do Capital Humano; Projeto "A Rodar no Bairro".

Save the Children, from Romania, wishes to thank to: National Authority for Children's Rights Protection and Adoption (ANPDCA), Concordia Humanitarian Organization, General Directorate of Social Assistance and Child Protection Districts 2, 3, 4 and 5, Liceul Tehnologic "Dragomir Hurmuzescu" (București), Școala Gimnazială "Ion I.C. Brătianu" (București), Școala Gimnazială "Liviu Rebreanu" (București), Şcoala Gimnazială "Mircea Sântimbreanu" (București), Școala Gimnazială "Petre Ghelmez" (București), Școala Gimnazială "Sfinții Voievozi" (București), Școala Gimnazială "Uruguay" (București), Școala Gimnazială Nr. 20 (București), Școala Gimnazială Nr. 80 (București), Școala Gimnazială Nr. 143 (București), Școala Gimnazială Nr. 181 (București), Școala Gimnazială Nr. 195 (București), Teach for Romania.

University of Northampton, from the UK, wishes to thank to: The Rushmere Academy (Northampton), The Rushmere Academy (Northampton), Right Resolutions CiC (Northampton), Hospital and Outreach Education Northampton, Northamptonshire Police - Early Intervention Hub, Northamptonshire Youth Offending Service (Northampton), Prospects Services (Northampton), City College Peterborough (Northampton), Central Bedford College (Bedford). 


\section{EXECUTIVE SUMMARY}

The report Stories of young dropouts. A social survey of success and failure covers the research, methodology, fieldwork activities, analysis of data and conclusions regarding Output 1 of the Below 10 Project. It focuses on the causes and characteristics of school failure and early school leaving. It was carried out by all partners of the Below 10 project on its first phase, and contains data collected locally in the following countries: Croatia, France, Italy, Portugal, Romania and United Kingdom. The research sought to answer the following questions: 1) what are the causes of early school leaving and dropping out at a local level; 2) how can early school leaving and dropping out be reduced?

The output aims were a) to give voice to young people's experiences and the process, causes and effects of early school leaving, retention and dropping out; b) to gather a number of "typical histories" of early school leaving or risks of dropping out that reflect the different situations in which early school leaving occurs; c) to identify the complex factors, actions, and views underlying early school leaving not only at individual level but also at school and community levels.

To meet these aims, we conducted interviews and focus groups with 291 young people and also with 36 family members, 101 education and training practitioners, 70 non-school practitioners and 9 other stakeholders.

Through the analysis of the interviews and focus groups, it was possible to identify various aspects related to 4 types of factors in the origin of failure and school leaving: individual, family, school and community. Early school leaving is a complex, multi-dimensional phenomenon with numerous causes and consequences.

With respect to individual factors, we find aspects connected with (de)motivation and inadequate attitudes; (excess of) responsibilities and financial constraints, lack of autonomy and responsibility and health challenges.

Concerning family factor, the analysis has shown how dropout is result of fundamental inequities. Prevailing social conditions of these youngsters have impact on their academic path, especially problems related with lack of economic resources in their households, but also family structure, family relationships and family difficulties in engaging with education and school. 
School related factors are the most numerous of all factors identified by the research participants, whether young people or adults. Most often school-related characteristics are revealed as determinants of dropout over and above family-related, individual-related and other motives. The relationship between teachers and pupils, the pedagogies used, the school management modalities and the absence of structures of participation seem to have a significant impact on students' engagement.

Finally, community factors, connected with social contexts, sociability networks, neighbourhood characteristics, resources and institutions are less present in the narratives and reflections of the research participants. The negative influence by peers, absence of positive role models and prevalence of moral values that undervalue school as a mobility opportunity are the most referred aspects.

In the 29 life histories of the European youngsters we could contact with the diversity and complexity of the youngsters' trajectories in education systems that are different among countries. Different national examples show that access to education is not assured for all; and that even when the family resources are steady, the massive undifferentiated school organization, and its aggressive school environment, trigger harmful effects - vulnerability and several types of abuses (from peers, parents or teachers), invisibility, isolation or demotivation in students. Other examples show the school's incapacity to manage and compensate the youngsters' resources deprivation. They also show the difficulty youngsters have in navigating school tracks - multiple and mismatched with the needs and vocational orientations of the youngsters. These examples also signal the important role the external organizations have in providing support to youngsters and their families. Included in these organizations are socialtherapeutic communities, social and school inclusion projects based in arts, and community associations. These contribute in a significant way to the processes of vocation and development self-discovery, and in providing a support network that counteract young people isolation.

Overall, the research concludes that the problem of early school leaving implies more than the notion of students failing to achieve academically and graduating from school. The issues may be, more precisely, not only how to better prepare them for schooling, but how to attune parents, schools and communities more to their diverse needs. With the research we learned 10 lessons learned concerning to this; they were included in the conclusions' chapter. 


\section{INTRODUCTION}

The present report covers the research, methodology, fieldwork activities, analysis of data and conclusions regarding Output 1 - Social Survey of the Below 10 Project. It focuses on the causes and characteristics of school failure and early school leaving (ESL hereafter). It was carried out by all partners of the Below 10 project on its first phase, and contains data collected locally in the following countries: Croatia, France, Italy, Portugal, Romania and United Kingdom.

The research sought to answer the following questions: 1) what are the causes of early school leaving and dropping out at a local level; 2) how can ESL and dropping out be reduced?

Educational outcomes currently assume an unprecedented weighting in the process of individual development and self-representation. The "school trajectory, generalised, merges with the actual biographic construction of the young person" (Vieira, 2010, pp. 278) ${ }^{1}$ and school inscribes "institutional self-confidence" in individuals (Martucelli, 2006, pp.45)2, rewriting experiences based upon academic evaluations through actions of confirmation, certification or refutation and doubt. Education processes may have emancipative or vulnerability effects, generating exclusion. Schools are for this reason both environments reproducing the prevailing social inequalities as well as producing new inequalities (Bourdieu, Passeron, 19703; DuruBellat, 20024).

Grasping the reasons for which young people abandon schools or accumulate failures along their trajectory, especially at the local level, is therefore fundamental to design and implement appropriate interventions. Dropping out is perceived as the culmination of a complex process of progressive distancing from schooling, interconnected with learning difficulties, low performance levels, absenteeism and behaviours deemed inappropriate by the system (European Commission, 20155).

Literature reviews highlight two types of factors leading to school dropout: individual (performance, attitudes and background) and institutional (families, schools and communities)

\footnotetext{
1 Vieira, M. M. (2010), "Incerteza e individuação: escolarização como processo de construção biográfica", in Sociologia, 20, pp.265-280.

2 Martucelli, D. (2006), Forgé par l'Épreuve. L'Individu dans la France Contemporaine, Paris, Armand Colin.

${ }^{3}$ Bourdieu, P., J.-C. Passeron (1970), La Reproduction. Éléments pour une Théorie du Système d'Enseignement, Paris, Minuit.

${ }^{4}$ Duru-Bellat, M. (2002), Les Inegalités Sociales á l'École? Genèse et Mites, Paris, PUF.

5 European Commission (2015), Schools policy: a whole school approach to tackling early school leaving. Policy messages, ET2020 Working Group on Schools Policy, DG Education and Culture. Education + Training.
} 
(De Witte et al., 20136; Rumberger, 20117). However, this also identifies some stereotypes predominantly interconnected with this phenomenon, such as the greater explanatory incidence of the individual factors (and, among these, demographic and individual characteristics such as gender or race) and family influences and only afterwards do there emerge school related factors and a lower observation of factors related to community, employment and connections with peer groups (Thyssen et al., 2010) ${ }^{8}$. This "hierarchy" of factors, to a certain extent, "naturalises" the phenomenon and hinders efforts either to build new paradigms of understanding and action or to develop a comprehensive perspective on both the exogenous and endogenous systemic causes (Sebastião, Álvares, 2015). ${ }^{9}$

In this report, we adapt the typical distinction between "individual factors" (student characteristics) and "institutional factors" (family, school and community characteristics), as made by Rumberger (2004). ${ }^{10}$ However, we individualize the institutional factors, thus rebalancing the discussion. We consider that neither individual attributes, nor family or school characteristics can be seen apart from society at large. We also agree with this author about the fact that it is a very difficult task to prove sustained causal effects of the many factors involved in early school leaving, because their impact is cumulative and changes over time. He considers early school leaving is the final outcome of a dynamic, cumulative and multidimensional process of disengagement.

The European Union defines early school leavers as people aged 18-24 who have lower secondary education or less and are no longer in education or training. ${ }^{11}$ The term is often

\footnotetext{
${ }^{6}$ De Witte, K., S. Cabus, G. Thyssen, W. Groot, H. M. van den Brink (2013), "A critical review of the literature on school dropout", in Educational Research Review, 10, pp.13-28.

${ }^{7}$ Rumberger, R. W. (2011), Dropping out. Why students drop out of high school and what can be done about it, London, Harvard University Press.

8 Thyssen, G., K. De Witte, W. Groot, H. M. van den Brink (2010), Preventing school dropout: A critical review of the literature, TIER Maastricht Working Paper Series, http://www.tierweb.nl /tier/assets/files/UM/Working\%20papers/TIER\%20WP\%2014-14.pdf (visited 18/11/2017).

9 Sebastião, J., M. Álvares (2015), "Wavering between hope and disenchantment. The case of early school leaving in Portugal”, in Scuola democratica, 6, 2, pp.439-454.

${ }^{10}$ Rumberger, R.W. (2004), “Why students drop out of school?” In: G. Orfied (Ed.), Dropouts in America: Confronting the Graduation Rate Crisis, Cambridge, MA, Harvard Education Press, pp. 131-155.

11 Council Conclusions of 5 May 2003 on reference levels of European average performance in education and training (Benchmarks) (2003/C 134/02).
} 
distinguished from the term 'school dropout' which refers to discontinuing an ongoing course in general or vocational education and training", 12 e.g. dropping out in the middle of term. ${ }^{13}$

Early school leaving can take several forms. ESL refers generically to failure to complete upper secondary school, failure to complete compulsory schooling or a failure to gain qualifications or school leaving certificates. It therefore includes young people who have dropped out of school before the end of compulsory education, those who have completed compulsory schooling but have not gained upper secondary qualifications and those who have taken pre-vocational or vocational courses that did not lead to a qualification equivalent to upper secondary level. Young people who initially drop out of school but then return to finish upper secondary education before the age of 25 are not regarded as early school leavers. In this study, early leavers are broadly defined as 15-24 year-olds with low qualifications who are no longer in education or training.

In many cases early school leaving is the result of a process or progressive disengagement from education, linked to learning difficulties, underachievement, absenteeism and inappropriate

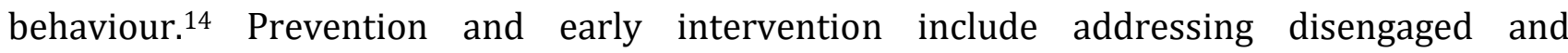
underachieving students who are attending school in such a state of total demotivation that they achieve no or very low learning attainment. Disengaged students are also a Below 10 target group. ESLers are not a homogenous group whether from the social or the schooling point of view despite tending to include more male and foreign-born students (European Commission, $2013,2017)^{15}$.

This group is usually linked to young people, or 'youth'. There is no commonly agreed definition of youth since it can be considered a transition phase. Youth can be defined as "the passage from a dependent childhood to independent adulthood".16 Institutions such as the EU, Eurostat and

\footnotetext{
12 Directorate General for Education and Culture (2011), Data Collection on and Monitoring of Early School Leaving (ESL), Thematic Working Group (TWG) on Early School Leaving, in <http://ec.europa.eu/dgs/ education_culture/repository/education/policy/strategic-framework/doc/data-monitoring-esl_en.pdf>

13 European Centre for the Development of Vocational Training. (2008), Terminology of European education and training policy: a selection of 100 key terms, Office for Official Publ. of the European Communities.

${ }^{14}$ European Union (2015), Schools policy: a whole school approach to tackling early school leaving. Policy messages, ET2020 Working Group on Schools Policy (2014-2015).

15 European Commission (2013), Reducing early school leaving: Key messages and policy support. Final Report of the Thematic Working Group on Early School Leaving, http://ec.europa.eu/education/policy/strategicframework/doc/eslgroup-report en.pdf (visited 14/1/2016). European Commission (2017), The Education and Training Monitor, Luxembourg, Publications Office of the European Union.

16 Walther, Andreas, Gry Moerch Hejl, Torben Bechmann Jensen (2002). 'Youth Transitions, Youth Policy and Participation. State of the Art Report.
} 
OECD most commonly use the age group between 15 and 29.17 This transition is why, as a category, youth is more fluid than other fixed age groups. Yet age is the easiest way to define this group, particularly in relation to education and employment, because youth often refers to a person between leaving compulsory education and finding their first job. ${ }^{18}$

That being said, young people, or youth, is the reference for one of our target groups as people are generally considered children up to the age of 14. Considering that ESL normally happens during upper secondary school, though its first signs are often there during lower secondary education, our project also investigates pre-adolescence, age 11 to 14 .

The report is structured as follows. The first two chapters provide the design of the social survey at Below 10. In the next chapter we provide the description of the project, the presentation of the participating organisations, we explain key objectives and describe main activities implemented to reach the objectives, as well as target groups of the activities. Chapter 2 focuses on the aims and methodologies applied in order to collect data to get to know the causes and characteristics of early school leaving, failure and school dropout. It means describing the research phases and methodology, the working scheme and description of the templates used and activities carried out by each partner. The characterization of the participants involved in the research is also included in this chapter.

A second group of chapters provide analysis of secondary and primary data. Chapter 3 is concerned with reporting contexts for the situation of ESL in each participating country and with local initiatives and practices. Chapter 4 examine research results from the primary data. Here we notice key findings from the interviews and focus groups conducted with youngsters, on one hand, and with adults and stakeholders, on the other hand.

The third group of chapters address content and ideas for action. Chapter 5 assess recommendations from youngsters, adults and stakeholders, regarding prevention of ESL, promotion of school success and dropout fight in the European countries from the partnership. The final chapter provides reflection and the 10 lessons learned with the project.

17 European Commission (2011). Commission Staff Working Document on EU indicators in the field of youth. SEC(2011) 401 final. Retrieved from http://ec.europa.eu/youth/library/publications/indicator-dashboard_en.pdf. See also EUROSTAT (2009), Youth in Europe: A statistical portrait, Luxembourg: Publications Office of the European Union, available at http://pjp-eu.coe.int/documents/ 1017981/1668203/YouthinEurope.pdf/40f42295-65e4407b-8673-95e97026da4a.

18 As mentioned in UNDESA - United Nations Department of Economic and Social Affairs - Fact Sheet (http://www.un.org/esa/socdev/documents/youth/fact-sheets/youth-definition.pdf). 


\section{DESCRIPTION}

\subsection{Participating organizations}

Below 10 is a project started in 2016, which will last until 2019. It is funded by Erasmus+ programme and leaded by Progettomondo.mlal, in Italy. The project is promoted by a partnership of 9 organizations (leading organisation included) from six countries. The other eight organizations are: Association Service Social Familial Migrants (ASSFAM) ${ }^{19}$ from France; Azienda Formazione Professionale SCARL (AFP) from Italy; Fondazione Cassa Di Risparmio Di Cuneo (CRC) from Italy; Save the Children (Romania); Srednja škola Dalj from Croatia; The University of Northampton (UON) from the United Kingdom; Udruga za rad s mladima Breza (BREZA) from Croatia. Six countries are involved: Italy, Croatia, France, Portugal, Romania and United Kingdom.

The social survey, which underlies the Intellectual Output 1, has been coordinated by CIES-IUL, Portugal, although all partners had participated in it. All the work that is reported in this document has been subject of discussion and co-participated decisions on partners' meetings.

\subsection{Objectives of the Intellectual Output 1}

The intellectual output 1 concerns the collection of information and its analysis. The objectives of the output were: 1) to conduct qualitative social research into ESL's processes, causes, modes and indicators in the different countries, giving voice to protagonists of these processes; 2) to provide an up to date picture of the different profiles of young dropouts in the European countries involved in the project; 3 ) to provide a current picture of the characteristics of current school dropouts to those who study and combat ESL; 4) to include and be aware of the individual, local and European levels in our final analysis; 5) to take account of the singularities of each of the territories.

\subsection{Target groups}

To meet the objectives, voice was given to young's experiences in order to gather 'typical histories' of early school leaving or risks of dropping out that reflect the different situations in

${ }^{19}$ In 2018 the former organization was extinct and the partner now is named Groupe SOS Solidarités ASSFAM. 
which ESL occurs, and to know what perceptions they have of the processes, causes and effects of early school leaving, retention and dropping out.

To complement this evidence, we consulted adults, stakeholders of the process, such as family members, education and training practitioners, and non-school practitioners.

\section{a) Young people}

The project proposal foreseen conducting focus groups and in-depth interviews with young people, as it would allow us to gather the information to build life histories in order to meet part of the aims of the I01 (the others were with stakeholders). As part of the research, it was predicted to interview 30 young people in each of the territories involved, both through individual interviews or focus groups.

The selection criteria foreseen in the project proposal regarding youngsters meant the involvement of boys and girls who have left school early and those who are still enrolled in education. Given that ESL has a gender dimension, as it is predominantly a male phenomenon, initial intention was to give them precedence in selection of the final participants.

Therefore, regarding young participants:

- the sample was identified within partner schools and other schools involved in the first few weeks of the project in collaboration with local authorities and regional school boards, local social services, local employment services and local networks of associations and young people;

- they come from schools, vocational training centres, education programmes for disadvantaged groups and other social and education services that work closely with young people;

- gender, age, background and nationality was balanced and equally represented in the sample, whenever possible.

Five youth profiles were used, according to their relationship with education and training:

1. Young people who have left school early and are not in full-time education, employment or training (NEET)

2. Employed young people who have not completed upper secondary education or vocational training (no recognised certification because they failed exams or left school early) 
3. Young people who have been held back and are at high risk of early school leaving

4. Young people who have returned after a period of suspension from school

5. Young people enrolled in education or vocational training.

\section{a) Stakeholders}

Focus groups and in-depth interviews were conducted with adults and stakeholders engaged or interested in preventing ESL, who delivered information about the actions, views and meanings associated with ESL. Interviews covered representatives of the following groups:

a. Education and training practitioners: head teachers, representatives of vocational training institutions, teachers, educators, school counsellors, mentors, other school staff and operators, trainers.

b. Non-school practitioners: public officials, local government officials, heads of associations, researchers, youth workers, social workers, workers and volunteers in cultural, sports and social associations, local employment services, local networks of associations and local youth associations.

c. Families of young people having difficulties at school and parents' associations.

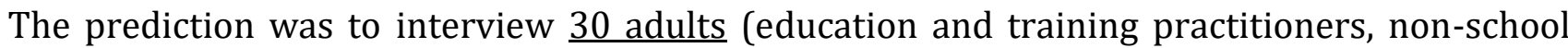
practitioners and family members), whether in individual interviews or focus groups, in each one of the territories involved in the social research I01.

As shown in Table 1.1, in the research we intended to involve 60 people from both targets in each territory, totalizing 420 people. The number of planned interviews to youngsters were 5 (in each territory), totalizing 35. Three focus groups with young people were to be conducted in each territory, 21 in total. Regarding the stakeholders, 4 focus groups were forecasted by territory, which sums 28 focus groups.

As the research is qualitative, the number of participants was not the primary concern, although it was important to reach a number of participants that would have assured covering the diversity of categories in the profiles of both target groups. 


\begin{tabular}{l|l}
\hline Per territory - planned & All territories - planned \\
\hline Involve 30 young people & 210 young people \\
Involve 30 adults & 210 adults \\
\hline Total 60 people & Total 420 people \\
\hline To conduct 5 interviews to youngsters & 35 interviews \\
To conduct 3 focus groups with youngsters & 21 focus groups \\
To conduct 4 focus groups adults & 28 focus groups \\
\hline Total focus groups -7 & 49 focus groups \\
\hline
\end{tabular}

Note: Project proposal refers to 6 countries and 7 territories [one for partner country, plus Cuneo and Villafranca (Verona) for Italy). Total are calculated according to the number of territories].

Table 1.2 offers an overview of the fieldwork in all territories, comparing the records of what was planned with what was achieved. The total amount of interviews (35 versus 70 ) and focus groups (49 versus 62) was exceeded and more participants were reached $(\mathrm{N}=507)$ than what was predicted in both target groups and taking both methodologies in account.

Table 1.2 Number of participants in each target group and methodology - totals planned and achieved

\begin{tabular}{|c|c|c|}
\hline \multicolumn{2}{|c|}{ All territories- planned } & All territories - achieved \\
\hline \multirow{3}{*}{ Total } & To involve 210 young people & 291 young people involved \\
\hline & To involve 210 adults & 216 adults involved \\
\hline & Total 420 people & Total 507 people \\
\hline \multirow{3}{*}{ Interviews } & To conduct 35 interviews with young people & 51 interviews conducted with young people \\
\hline & To conduct NS interviews with adults & 19 interviews conducted to adults \\
\hline & Total interviews - 35 & Total interviews - 70 \\
\hline \multirow{3}{*}{ Focus Groups } & To conduct 21 focus groups with young people & 33 focus groups conducted with YP \\
\hline & To conduct 28 focus groups with adults & 29 focus groups conducted with adults \\
\hline & Total focus groups - 49 & 62 focus groups \\
\hline
\end{tabular}

Note: Project proposal refers to 6 countries and 7 territories [one for partner country, plus Cuneo and Villafranca (Verona) for Italy). Total are calculated according to the number of territories].

In each of the territories the number of focus groups $(n=7)$ and the number of interviews $(n=5)$ to be conducted has been reached or overpassed, irrespective of the target group (see Table 3). Each participant has a minimum of 7 focus groups and a minimum of 6 interviews. The higher number of interviews was conducted by the UK and France ( $n=17)$. In France more focus groups were conducted $(n=13)$ than in any of the other territories. 
Table 1.3 Number of focus groups and interviews in each territory

\begin{tabular}{|c|c|c|}
\hline Territories & $\mathrm{FG}(\mathrm{N})$ & Interviews (N) \\
\hline Croatia & 7 & 6 \\
\hline France & 10 & 17 \\
\hline Italy - Cuneo & 13 & 9 \\
\hline Italy - Villafranca (Verona) & 8 & 8 \\
\hline Portugal & 8 & 6 \\
\hline Romania & 9 & 7 \\
\hline United Kingdom & 7 & 17 \\
\hline Total & 62 & 70 \\
\hline
\end{tabular}

Note: Project proposal refers to 6 countries and 7 territories [one for partner country, plus Cuneo and Villafranca (Verona) for Italy). Total are calculated according to the number of territories]. 


\subsection{Aims and activities}

Output 1 comprised three main activities specified in the following paragraphs.

On one hand, ESL was contextualised by an analysis of each national and local school systems (political initiatives and good practices included).

On other hand, youngsters and stakeholders were consulted, through the use of qualitative tools, i.e. interviews and focus groups, and asked to identify the complex decisions, actions, attitudes, behaviour and views underlying ESL not only at individual level but also at family, school and community levels. Interviews were conducted and focus groups formed at national level by each participating country.

Finally, all partners gathered a substantial number of "typical histories" of early school leaving or risks of dropping out that reflect the different situations in which ESL occurs. As mentioned above, these include not only young people who have dropped out but also those who are still in education or training, their families and representatives of schools and local education agencies.

The countries have analysed and reported on activities using the templates (shown in annexes). The collected information was subject of analysis and is now reported in the following sections and chapters. The key knowledge collected will inform 02 - Output 2.

\subsection{Research methodology}

\section{Data collection}

Data collection was carried using interviews and focus groups. Interviews were used also as the base to the life histories gathering.

Some common guiding principles for the fieldwork were provided to all partners on behalf of the research. Templates of ready-to-go guides with open-ended questions aimed at collecting qualitative aspects and insights were, then, agreed among all partners, based on indexes of dimensions, indicators and possible questions according to the respondents' profile, variables and dimensions central to an understanding of ESL converted into indicators by which they 
could be elicited, analysed and synthesized. Annexes 1, 2 and 3 of this document include a set of questions that each partner translated into local languages and used during fieldwork.

A grounded-theory perspective was followed, meaning that interpretations and stories emerged from the data. Grounded theory is an approach that is "grounded in data systematically gathered and analysed". ${ }^{20}$ Thus, beginning with a broad topic (causes and effects of ESL) we used qualitative methods and instruments to collect further information on the subject.

Orientations about how to conduct an interview, a focus group or gather a life history, as much as the research ethic principles, were shared and debated within the partnership. Research with young people requires youth friendly strategies, and participative and horizontal safe environments. Methods such as focus group and interviews are applicable and valid to achieve these goals. It was ensured that the research met all the ethical and safety requirements. Youths were informed and clarified about the research content and aims. The research process was developed in ways that: a) maximise the benefits of involvement for participants while reducing potential harms; b) provide full information of the risks and benefits of participation; c) assure freedom to not participate; d) enhance capacities for participants to give informed consent, and e) guarantee confidentiality.

All work processes have been discussed and clarified in work meetings.

\section{Data analysis}

After the process of data collection by each partner in its own territory, analysis was carried out and reported. Not only interviews and focus groups, but also national statistics, documentation and reports are the sources of the information we analysed.

Thematic content was analysed on the basis of templates provided by the research coordinator and agreed within the partnership. Orientations were provided to fill in the templates. A package of outcomes from each partner informed this 01 final report: the "File 01 fieldwork final report" (an Excel file); the Final Report Template (Annex 4). The final report templates completed by each partner included the following sections:

a) national and local official definitions of Early school leaving and early leavers;

\footnotetext{
20 Strauss, A. \& Corbin, J. (1994). "Grounded Theory Methodology." In NK Denzin \& YS Lincoln (Eds.) Handbook of Qualitative Research (pp. 217-285). Thousand Oaks, Sage Publications.
} 
b) recent national ESL statistics (national and local);

c) identification of national and local policies and initiatives on ESL prevention and student re-engagement (maximum 3 initiatives);

d) data collected from interviews and focus groups with adults/stakeholders (individual, family, school and community factors explaining disengagement and ESL), significant quotes and recommendations of adults/stakeholders on actions to reduce ESL;

e) data collected from interviews and focus groups with young people (individual, family, school and community factors explaining disengagement and ESL), significant quotes and recommendations of youngsters on actions to reduce ESL;

f) life histories of young people.

The outcomes of the listed templates are detailed in chapter 3, 4 and 5 . In this chapter we start with the details of what was followed in the methodology and go on characterizing the participants according to what was reported in the Excel files of all the partners.

As shown in Table 2.1, the interviews were conducted particularly with young people: in a total amount of 70 participants, 51 were within this target group. The group of education and training practitioners was the second with more interviews in the whole set, although with a great distance $(n=9)$.

Table 2.1 Number of participants in interviews $(\mathrm{N})$

\begin{tabular}{lccccccrr}
\hline & HR & FR & IT_C & IT_VdV & PT & RO & UK & Total \\
\hline Young person) & 6 & 6 & 9 & 4 & 6 & 7 & 13 & 51 \\
Family member & - & 1 & - & 1 & - & - & - & 2 \\
$\begin{array}{l}\text { Education and training } \\
\text { practitioners }\end{array}$ & - & 5 & - & 1 & - & - & 3 & 9 \\
Non-school practitioners & - & 5 & - & 1 & - & - & 1 & 7 \\
Others & - & - & - & 1 & - & - & - & 1 \\
Total & 6 & 17 & 9 & 8 & 6 & 7 & 17 & 70 \\
\hline
\end{tabular}

In what concerns focus groups, a total of 437 people was involved in all territories. Taking into account all focus groups, the most representative group was also the youngsters, with 240 participants. And, again, education and training practitioners were the second most representative group reached through this method, with 92 participants (see Table 2.2). 
Table 2.2 Number of participants in focus groups $(\mathrm{N})$

\begin{tabular}{lrrrrrrrr}
\hline & HR & FR & IT_C & IT_V & PT & RO & UK & Total \\
\hline Young person) & 22 & 34 & 80 & 20 & 28 & 38 & 18 & 240 \\
Family member & 4 & 8 & 6 & 5 & 5 & 6 & - & 34 \\
Education and training & 17 & 8 & 11 & 20 & 12 & 11 & 13 & 92 \\
practitioners & 11 & 21 & 9 & 3 & 11 & 8 & - & - \\
Non-school practitioners & - & 2 & - & 6 & - & - & 83 \\
Others & 54 & 73 & 106 & 54 & 56 & 63 & 31 & 437 \\
Total & & & & & & & & \\
\hline
\end{tabular}

The total participants in both methodologies are shown in table 2.3: 507 participants, both youngsters and adults. Italy (both territories) and France have the most numerous samples.

Table 2.3 Number of participants in interviews and focus groups (N)

\begin{tabular}{lrrrrrrrr}
\hline & HR & FR & IT_C & IT_V & PT & RO & UK & Total \\
\hline Young person) & 28 & 40 & 89 & 24 & 34 & 45 & 31 & 291 \\
Family member & 4 & 9 & 6 & 6 & 5 & 6 & - & 36 \\
Education and training & 17 & 13 & 11 & 21 & 12 & 11 & 16 & 101 \\
practitioners & 11 & 26 & 9 & 4 & 11 & 8 & 1 & 70 \\
Non-school practitioners & - & 2 & - & 7 & 0 & - & - & 9 \\
Others & 60 & 90 & 115 & 62 & 62 & 70 & 48 & 507 \\
Total & & & & & & & & \\
\hline
\end{tabular}

\subsection{Participants: characterization of who were involved in the research}

After the development of all activities and the reception of the templates filled in by all partners, we started to register the information in a database, to retrieve the characterization regarding all variables to characterize (profiles, categories, and ages, among the others mentioned above) and register in tables to report here by partner. As the variables to meet were not similar between youngsters and adults, and is important to report data for each target group, we present a separate characterization.

\section{Young people}

Table 2.4 shows the distribution of young people by profile in each country. The profile most represented in the overall sample is the one of young people at high risk of early school leaving, with $30.6 \%$. Portugal is the sole country that also has this group as the most representative, with 
64.7\%. In Italy, Romania and UK, young people at risk of early school leaving ranks second, with values between 24.4 per cent and 32.3 per cent.

In France and in the UK, young people enrolled in education or training is the most representative group with weights respectively from 30 to 52 per cent. Both in Croatia and Italy, the first profile in the rank is young people who have returned to school or training (respectively, a rounded 43 per cent and 34.5 per cent).

Romania has the same proportion of young people at high risk of early school leaving and young people who have returned to school or training, with a rounded 24 percent.

We conclude, so far, that the sample is diversified. Around 3/4 are distributed among young people at high risk of early school leaving, young people who have returned to school or training, and young people enrolled in education or training. Less represented in the general sample is the group of NEET (rounded 8 per cent). Croatia, Portugal and Romania were the countries that have higher proportions on that group.

Table 2.4 Young people involved, by profile (\%)

\begin{tabular}{|c|c|c|c|c|c|c|c|}
\hline & $\mathrm{HR}$ & FR & IT & PT & $\mathrm{RO}$ & UK & Total \\
\hline YP who have left school early (NEET) & 17.9 & 7.5 & 2.7 & 14.7 & 15.6 & - & 7.9 \\
\hline $\begin{array}{l}\text { Employed YP without upper secondary } \\
\text { education }\end{array}$ & 7.1 & 15.0 & 14.2 & 2.9 & 22.2 & - & 12.0 \\
\hline YP at high risk of early school leaving & 14.3 & 25.0 & 28.3 & 64.7 & 24.4 & 32.3 & 30.6 \\
\hline YP who have returned to school or training & 42.9 & 20.0 & 34.5 & 8.8 & 24.4 & 16.1 & 26.8 \\
\hline YP enrolled in education or training & 17.9 & 30.0 & 20.4 & 8.8 & 13.3 & 51.6 & 22.3 \\
\hline Other & - & 2.5 & - & - & - & - & 0.3 \\
\hline Total & 100.0 & 100.0 & 100.0 & 100.0 & 100,0 & 100.0 & \\
\hline
\end{tabular}

Considering the age distribution (see Table 2.5), the highest proportions in half of the countries, namely in France (65 per cent), Portugal (44.1 per cent) and Croatia (35.7 per cent) are in ages between 17-19 years or between 14-16 years, as in Italy (38.1 per cent) or the UK (58.1 per cent).

Pre-adolescents' participation comes specifically from Romania, the only country where young people between the ages of 11 and 13 years is the most represented group (37.8 per cent). Also Italy involved 2.7 per cent of participants in the research who are aged between 11 and 13 years. Young people with more than 25 years represent 14.3 per cent of the sample from Croatia, 10 per cent of the participants from France, rounded 10 per cent of the participants from Italy and 
rounded 9 per cent of the youth participation from Romania. Only in Portugal and UK there is no participants older than 25, in accordance with the reference group for the theme of ESL.21

Table 2.5 Young people involved, by age (\%)

\begin{tabular}{lrrrrrrr}
\hline & HR & FR & IT & PT & RO & UK & Total \\
\hline $11-13$ & - & - & 2.7 & - & 37.8 & - & 6.9 \\
$14-16$ & 25.0 & 12.5 & 38.1 & 41.2 & 28.9 & 58.1 & 34.4 \\
$17-19$ & 35.7 & 65.0 & 26.5 & 44.1 & 20.0 & 35.5 & 34.7 \\
$20-25$ & 25.0 & 12.5 & 23.0 & 14.7 & 4.4 & 6.5 & 16.2 \\
More than 25 & 14.3 & 10.0 & 9.7 & - & 8.9 & - & 7.9 \\
Total & 100.0 & 100.0 & 100.0 & 100.0 & 100.0 & 100.0 & 100.0 \\
\hline
\end{tabular}

Regarding gender (see Table 2.6), we can highlight the Portuguese equal distribution of male and female participants and the fact that in the overall sample most participants are male (63.6 per cent). By country, France (72.4 per cent), Italy (75.2 per cent) and Romania (68.9 per cent) have more male young participants. Croatia and the UK samples are, inversely, feminized (67.9 per cent female young participants in the former and 54.8 per cent in the latter).

Table 2.6 Young people involved, by gender (\%)

\begin{tabular}{lrrrrrrr}
\hline & HR & FR & IT & PT & RO & UK & Total \\
\hline Female & 67.9 & 27.5 & 24.8 & 50.0 & 31.1 & 54.8 & 36.4 \\
Male & 32.1 & 72.5 & 75.2 & 50.0 & 68.9 & 45.2 & 63.6 \\
Total & 100.0 & 100.0 & 100.0 & 100.0 & 100.0 & 100.0 & 100.0 \\
\hline
\end{tabular}

Looking at the levels of education of the young people involved in the research showed in Table 2.7, we observe that Croatia is the only country that has participants representing all levels of education attained, except the post-secondary education/ISCED 4; participants from other countries are concentrated in less levels and, mostly, not higher than Post-secondary education/ISCED 4.

Most young participants (77.8 per cent) from Romania have no formal qualification or have incomplete primary, which is a singular feature of this country, as no other country has this low level of education so much represented in the schooling sample. By contrast, France has the highest educated sample, with 55 percent of the participants with the upper secondary

${ }^{21}$ France reported two participants in the focus groups with ages higher than 30 years. These two participants were included in the adults' sample, as "adults who have been ESL". 
vocational education/ISCED 3 attained. Most participants from Italy, 62.8 per cent, attained lower secondary general education/ISCED 2.

Portugal shows an interesting profile, as half of the sample concluded primary education/ISCED 1 and nearly 40 per cent attained lower secondary vocational educational/ISCED 2.

Table 2.7 Young people involved, by highest level of education attained (\%)

\begin{tabular}{|c|c|c|c|c|c|c|c|}
\hline & $\mathrm{HR}$ & FR & IT & PT & RO & UK & Total \\
\hline No formal qualification, incomplete primary & 3.6 & - & - & - & 77.8 & - & 12.4 \\
\hline Primary education/ISCED 1 & 25.0 & - & 23.0 & 50.0 & - & - & 17.2 \\
\hline Lower secondary general education/ISCED 2 & 10.7 & 2.5 & 62.8 & 5.9 & - & - & 26.5 \\
\hline Lower secondary vocational education/ISCED 2 & 14.3 & 37.5 & 12.4 & 38.2 & 20.0 & 22.6 & 21.3 \\
\hline Upper secondary general education/ISCED 3 & 14.3 & 2.5 & 1.8 & - & - & 58.1 & 8.6 \\
\hline Upper secondary vocational education/ISCED 3 & 21.4 & 55.0 & - & 5.9 & 2.2 & 16.1 & 12.4 \\
\hline Post-secondary education/ISCED 4 & - & 2.5 & - & - & - & 3.2 & 0.3 \\
\hline Short-cycle tertiary education/ISCED 5 & 3,6 & - & - & - & - & - & 0.3 \\
\hline Bachelor's or equivalent level/ISCED 6 & 3,6 & - & - & - & - & - & 0.3 \\
\hline Master's or equivalent level/ISCED 7 & 3,6 & - & - & - & - & - & 0.3 \\
\hline Total & 100.0 & 100.0 & 100.0 & 100.0 & 100.0 & 100.0 & 100.0 \\
\hline
\end{tabular}

One of the variables explaining ESL, as also revealed on interviews and focus groups data in chapter 4 , is the migrant background, which materializes, for example, in problems with learning due to the language difficulties. As shown in Table 2.8, France and the UK have the highest proportions of participants with migrant background (67.5 per cent in the former, 54.8 per cent in the latter), which is not a surprising fact due to cultural diversities these countries have related to historical immigration in both. France also has 10 per cent of participants with unspecified profile regarding that matter.

Romania and Croatia are the countries with less young participants with migrant background; Portugal and Italy have similar profiles: $2 / 3$ are native, the other $1 / 3$ of the participants have migrant background.

Table 2.8 Young people involved, by migrant background (\%)

\begin{tabular}{lrrrrrrr}
\hline & HR & FR & IT & PT & RO & UK & Total \\
\hline Native (no migrant background) & 85.7 & 22.5 & 63.7 & 61.8 & 100.0 & 45.2 & 63.6 \\
With migrant background & 14.3 & 67.5 & 36.3 & 31.2 & - & 54.8 & 35.1 \\
Unspecified & - & 10.0 & - & - & - & - & 1.4 \\
Total & 100.0 & 100.0 & 100.0 & 100.0 & 100.0 & 100.0 & 100.0 \\
\hline
\end{tabular}


Another variable that contributes to explain difference between stayers at school and early leavers is the socioeconomic status. In our research, young people with low socioeconomic status are strongly represented in all samples, although Romania has the highest concentration on this group, with only 4.4 per cent with medium socioeconomic status. Only France has participants with high socioeconomic status (see Table 2.9).

Table 2.9 Young people involved, by socioeconomic status (\%)

\begin{tabular}{lrrrrrrr}
\hline & HR & FR & IT & PT & RO & UK & Total \\
\hline Low socioeconomic status & 82.1 & 87.5 & 75.2 & 85.3 & 95.6 & 58.1 & 80.1 \\
Medium socioeconomic status & 17.9 & 7.5 & 17.7 & 14.7 & 4.4 & 9.7 & 13.1 \\
High socioeconomic status & - & 5.0 & - & - & - & - & 0.7 \\
Unspecified/unknown & - & - & 7.1 & - & - & 32.3 & 6.2 \\
Total & 100.0 & 100.0 & 100.0 & 100.0 & 100.0 & 100.0 & 100.0 \\
\hline
\end{tabular}

The analysis of the health condition of the participants indicates different realities among the countries, as shown in Table 2.10. In Croatia, nearly 68 per cent of the participants has a health condition (mostly due to the partner profile). The other country with participants in a large number with health condition is the UK, with 29 per cent. In France, Italy, Portugal and Romania, the group of participants without health condition is predominant $(95,99.1,94.1$ and 97.8 per cent).

Table 2.10 Young people involved, by health condition (\%)

\begin{tabular}{lrrrrrrr}
\hline & HR & FR & IT & PT & RO & UK & Total \\
\hline Unspecified/unknown & 35.1 & 95 & 99.1 & 94.1 & 97.8 & 71.0 & 88.3 \\
With health condition & 67.9 & 5.0 & 0.9 & 5.9 & 2.2 & 29.0 & 11.7 \\
Total & 100.0 & 100.0 & 100.0 & 100.0 & 100.0 & 100.0 & 100.0 \\
\hline
\end{tabular}

\section{Adults/stakeholders}

In this section the stakeholders who participated are characterised. As shown in Table 2.11, the research involved a total of 216 adults with different profiles, most of them education and training practitioners $(n=98,45.4$ per cent, as shown in Table 2.12). The second profile most represented in the research is the one of non-school practitioners, with 33.8 per cent and, in third, family members. 
Table 2.11 Stakeholders involved, by profile (n)

\begin{tabular}{lrrrrrrr}
\hline & HR & FR & IT & PT & RO & UK & Total \\
\hline Family members & 4 & 9 & 12 & 5 & 6 & - & 36 \\
Education and training practitioners & 17 & 13 & 32 & 12 & 11 & 13 & 98 \\
Non-school practitioners & 11 & 26 & 13 & 11 & 8 & 4 & 73 \\
Other & - & 2 & 7 & - & - & - & 9 \\
Total & 32 & 50 & 64 & 28 & 25 & 17 & 216 \\
\hline
\end{tabular}

By country, the most balanced sample is the one from the Portuguese partner (see Table 2.12). It follows the tendency of having more education and training practitioners (42.9 per cent) than other categories, although the representation of non-school practitioners is not much less (39.3 per cent). With the exception of France, which has more non-school practitioners in the sample, all other partners involved proportionally more education and practitioners in the research (53.1 per cent in Croatia, 50 per cent in Italy, 44 per cent in Romania and 76.5 per cent in the UK). Yet, Italy as 10.9 per cent of participants (Italy has 4 per cent) with other profile and the UK did not involve family members as participants in the research.

Table 2.12 Stakeholders involved, by profile (\%)

\begin{tabular}{lrrrrrrr}
\hline & HR & FR & IT & PT & RO & UK & Total \\
\hline Family members & 12.5 & 18.0 & 18.8 & 17.9 & 24.0 & - & 16.7 \\
Education and training practitioners & 53.1 & 26.0 & 50.0 & 42.9 & 44.0 & 76.5 & 45.4 \\
Non-school practitioners & 34.4 & 52.0 & 20.3 & 39.3 & 32.0 & 23.5 & 33.8 \\
Other & - & 4.0 & 10.9 & - & - & - & 4.2 \\
Total & 100.0 & 100.0 & 100.0 & 100.0 & 100.0 & 100.0 & 100.0 \\
\hline
\end{tabular}

Most adult participants in the research are women, as we can see in Table 2.13. As a matter of fact, 79.8 per cent of the participants are female. Higher than that percentage is the sample of Portugal, which has the most feminized group of participants among the overall sample with nearly 90 per cent. In this case, the two countries that show less feminized groups of stakeholders are France and Italy, both with around 40 per cent of female participants both in the conducted focus groups and interviews. 
Table 2.13 Stakeholders involved, by gender (\%)

\begin{tabular}{lrrrrrrr}
\hline & HR & FR & IT & PT & RO & UK & Total \\
\hline Female & 78.1 & 60.0 & 59.4 & 89.3 & 84.0 & 82.4 & 70.8 \\
Male & 21.9 & 40.0 & 40.6 & 10.7 & 16.0 & 17.6 & 29.2 \\
Unspecified & - & - & - & - & - & - & - \\
Total & 100.0 & 100.0 & 100.0 & 100.0 & 100.0 & 100.0 & 100.0 \\
\hline
\end{tabular}

Now, analysing the profile of the education and training practitioners and its categories in separate, and as shown in Table 2.14, teachers are the category mostly represented in the whole, with 60.2 per cent. For Croatia, Italy, Portugal and Romania, we find the same pattern (Table 2.13), with percentages between 63.6 (in Romania) per cent of 81.3 per cent (in Italy), concerning teachers in the profile of education and training practitioners. The most diverse group of education and training practitioners is found in the sample of Croatia, missing only head teachers and school counsellors.

France has an equal weight of school counsellors, teachers and other school practitioners as participants (30.8 per cent) in the profile of education and practitioners. The UK has a higher weight of "other school practitioners" in the profile of education and training practitioners than any other country (46.2 per cent) and a lower percentage of teachers than the other countries (23.1 per cent). Although not as much, both France and Romania have a significant percentage of other school practitioners (in that order, 30.8 per cent and 27.3 per cent).

Table 2.14 Stakeholders involved, by category of education and training practitioners (\%)

\begin{tabular}{|c|c|c|c|c|c|c|c|}
\hline & $\mathrm{HR}$ & FR & IT & PT & RO & UK & Total \\
\hline Head teacher & - & - & - & - & - & 15.4 & 2.0 \\
\hline School counsellor & - & 30.8 & - & 16.7 & 9.1 & - & 18.4 \\
\hline School mentor/tutor & 11.8 & - & - & - & - & 7.7 & 3.1 \\
\hline Teacher & 64.7 & 30.8 & 81.3 & 66.7 & 63.6 & 23.1 & 60.2 \\
\hline Trainer & 5.9 & - & 3.1 & 8.3 & - & 7.7 & 4.1 \\
\hline Vocational training institutions representative & 5.9 & 7.7 & 9.4 & - & - & - & 5.1 \\
\hline Other school practitioner & 11.8 & 30.8 & 6.3 & 8.3 & 27.3 & 46.2 & 18.4 \\
\hline Total & 100.0 & 100.0 & 100.0 & 100.0 & 100.0 & 100.0 & 100.0 \\
\hline
\end{tabular}

In what concerns the group of non-school practitioners as separate whole (see Table 2.15), all the categories included in it are represented. Social workers, with 27.4 per cent, and local government officers, with 19.1 per cent, have the highest weights within this profile. By country, we highlight Italy, that has the category of public official with the highest representation in the 
sample of education and training practitioners; Portugal, which has local government officials as the most represented category in this profile (with 37.5 percent), and youth workers or volunteers as the second most represented; and Romania, where non-school practitioners represent 37.5 percent of the education and training practitioners involved in the research.

Table 2.15 Stakeholders involved, by category of non-school practitioners (\%)

\begin{tabular}{|c|c|c|c|c|c|c|c|}
\hline & $\mathrm{HR}$ & FR & IT & PT & RO & UK & Total \\
\hline $\begin{array}{l}\text { Cultural, sports and social association work or } \\
\text { volunteer }\end{array}$ & - & 23.1 & - & 9.1 & - & - & 9.6 \\
\hline Head of association & - & 3.8 & 7.7 & - & - & - & 2.7 \\
\hline Local employment officer & 9.1 & 3.8 & - & - & - & 25.1 & 4.1 \\
\hline Local government official & 36.4 & 7.7 & 15.4 & 36.4 & 25.0 & - & 19.2 \\
\hline Public official & - & 23.1 & 30.8 & - & - & 25.0 & 15.1 \\
\hline Researcher & - & - & 15.4 & - & 12.5 & - & 4.1 \\
\hline Social worker & 36.4 & 38.5 & 23.1 & 9.1 & 12.5 & 25 & 27.4 \\
\hline Youth worker or volunteer & 9.1 & - & - & 27.3 & - & - & 5,5 \\
\hline Other non-school practitioner & 9.1 & - & - & 18.2 & 37.5 & 25.0 & 9.6 \\
\hline Total & 100.0 & 100.0 & 100.0 & 100.0 & 100.0 & 100.0 & 100.0 \\
\hline
\end{tabular}

Last, regarding categories and profiles of stakeholders, are the adults who have been ESL, family members and parents' association members. As shown in Table 2.16, we can see that in Italy there is a relative equal distribution between the three; in Croatia and Romania, only family members have taken part in the research; in France, 80 per cent are family members, and others are adults who have been ESL; in Portugal, only family members and parents 'association members have participated; and in the UK, only other profiles of the stakeholders have been interviewed.

Table 2.16 Stakeholders involved, by category of family members and others (\%)

\begin{tabular}{|c|c|c|c|c|c|c|c|}
\hline & $\mathrm{HR}$ & FR & IT & PT & RO & UK & Total \\
\hline Adults who have been ESL & - & 18.2 & 36.8 & - & - & - & 20. \\
\hline Family member & 100.0 & 81.8 & 31.6 & 40.0 & 100.0 & - & 60.0 \\
\hline Parents' association member & - & - & 31.6 & 60.0 & - & - & 20.0 \\
\hline Total & 100.0 & 100.0 & 100.0 & 100.0 & 100.0 & - & 100.0 \\
\hline
\end{tabular}




\section{SCHOOL FAILURE AND EARLY SCHOOL LEAVING IN EUROPE}

In this chapter we present the results of the research concerning national and local definitions of ESL, as well as local initiatives concerning ESL reported by the partners. Before reporting data from each partner, we provide some European global context data. In each country section, we also make a short analysis of ESL statistics and situation regarding targets.

\subsection{Contexts: situation of school failure and ESL in Europe and in each country}

To tackle early school leaving has become a key issue in Europe. One of the headline targets for education in the Europe 2020 strategy (ET 2020 hereafter) is to reduce the rates of ESL/ELET 22 below 10 per cent (by 2020) - naming the Below 10 Project itself. Therefore, in June 2011, education ministers agreed on a 'framework for coherent, comprehensive, and evidence-based policies' to deal with and develop solutions to overcome the underlying causes of early school leaving. ${ }^{23}$ Following this strategy, and since then, a group of policy makers and practitioners from across Europe have been working to look at examples of good practice on that matter and has promoted an exchange regarding them.

Most countries in Europe have their own definitions and data collections, in addition to the data gathered for the EU-Labour Force Survey (Eurostat). According to the Eurydice Brief, the exceptions are Belgium (German-speaking Community), the Czech Republic, Croatia, Cyprus, Hungary, Romania, Slovakia and the United Kingdom (Northern Ireland). ${ }^{24}$ In their own definitions and data collection methods, countries mainly use student registers or databases. Even if not been developed aiming at measuring early leaving, the registers and databases are used to monitor absenteeism and provide a proxy to alert schools and authorities when an intervention is needed to help students at risk of early leaving.

\footnotetext{
22 ELET - Early Leavers from Education and Training or ESL - Early School Leavers, are used in this report as meaning the same; we specify the circumstances when is not the case.

${ }^{23}$ EC/EACEA/Eurydice/Cedefop (2015), Eurydice Brief. Tackling Early Leaving from Education and Training in Europe, Luxembourg: Publications Office of the European Union.

24 EC/EACEA/Eurydice/Cedefop (2015), Eurydice Brief. Tackling Early Leaving from Education and Training in Europe, Luxembourg: Publications Office of the European Union.
} 
Europe is, in fact, progressing: starting the present decade at 13.9 per cent, the current share of early leavers from education and training is 10.6 per cent (see Figure 3.1), therefore getting near the ET 2020 (below 10). ${ }^{25}$

Figure 3.1 Share of early leavers from education and training, EU 28, 2010-2017 (\% of population aged 18 to 24 )

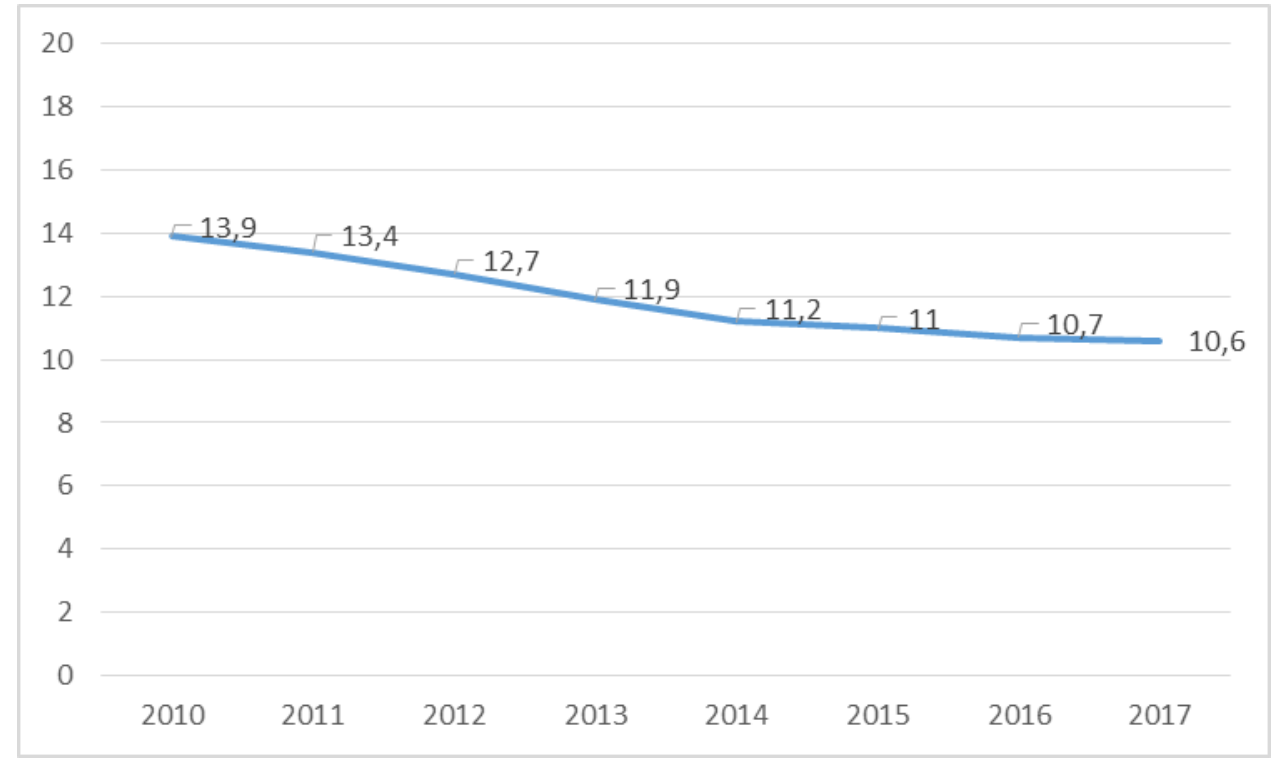

Source: Eurostat, data available at:

http://ec.europa.eu/eurostat/tgm/table.do?tab=table\&init=1\&plugin=1\&language=en\&pcode=sdg_04_10.

Considering the goal for each country, all, but the UK, have set their own national goals for ESL rates, taking into account national contexts regarding this issue when the ET 2020 benchmark was settled.26 It is important to highlight that these values range from 16 per cent for Italy, one of the project partners, to 4 per cent in Croatia, another project partner. Some Member States (Belgium, Denmark, Ireland, Greece, France, Croatia, Italy, Cyprus, Latvia, Lithuania, Luxembourg, Netherlands, Austria, Slovenia, Finland) have met their national targets - three more than in 2015 (Belgium, Netherlands and Finland) - thus confirming sustained progress towards the 2020 target (EC, 2017: 59).

The following sections are generically retrieved from the information sent by each partner concerning its country, with the exception of the Eurostat recent data presented at the beginning.

25 European Commission (2017), Education and Training Monitor 2017, Luxembourg: Publications Office of the European Union.

${ }^{26}$ European Commission (2017), Education and Training Monitor 2017, Luxembourg: Publications Office of the European Union. 


\section{Croatia}

In Croatia there is no separate definition of ESL than the one used in Europe: leaving school after completion of lower secondary level of education.

Recent statistics on ESL in Croatia, according to Eurostat, are shown on Figure 3.2. As mentioned before, Croatia already is below its national target regarding ESL (4 per cent).

Figure 3.2 Share of early leavers from education and training, Croatia, 2010-2017 (\% of population aged 18 to 24 )

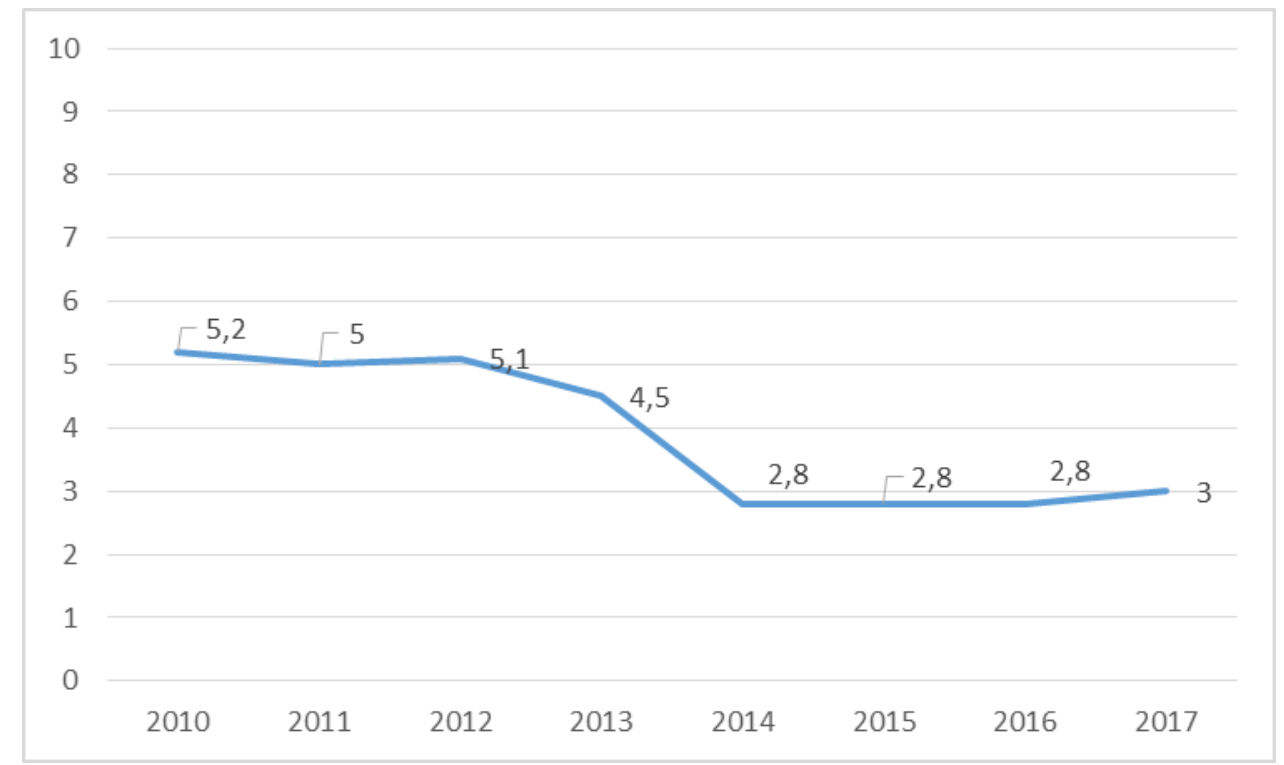

Source: Eurostat, data available at:

http://ec.europa.eu/eurostat/tgm/table.do?tab=table\&init=1\&plugin=1\&language=en\&pcode=sdg_04_10.

Plans of multilevel approach to schools and educators for motivate students to stay in schools have been implemented in this country, along with dialogue development between schools and administration, students and parents' initiatives. Other actions were guidance, school networking, innovative classrooms, more students' participation in school activities and school life. The competences of teachers and reflection about ESL, peer to peer support to students and teachers, parents' confidence and trust as well as engagement in school life are key subjects in which strategies have to be supported.

Regarding statistics, Croatia has established a national target of maintaining the rate of early leavers below $4 \%$ by $2020 .{ }^{27}$ But, according some researches of CSO's organisations on national level $(2015,2016,2017)$, that share is higher, especially in vocational secondary schools, up to

27 Eurostat, available at: http://ec.europa.eu/eurostat/web/products-eurostat-news/-/EDN-20170908-1, and Eurydyce/Cedefop Report (2013-14). 
$10 \%$ (Croatian Youth Network, Association Pragma). The main reason is absence of database and statistics which continuously accompany students through their education throughout their lives.

A national electronic database that tracks pupils through their education and vocational path has so far not been used to track the frequency of early school leaving in Croatia. Emphasis is also drawn to the fact that leadership in education and career building is not yet included in the national curriculum, rather than attended by professional associates in lower secondary schools - psychologists, social workers and social pedagogues - as well as the Career Information and Counselling Centre.

An indicator to take into account to weight the problem of ESL in Croatia is the percentage of 21.8\% youngsters with ages between 15 to 29 with NEET status (measure: Youth Guarantee Implementation Plan). In NEET group 15.4 per cent youth finished vocational secondary schools (2016, Croatian Youth Network).

\section{France}

In Figure 3.3 is showed the recent trend in ESL share in France. A decrease can be noted, as in other European countries, until 2014. As of that year, ESL share have had little variation.

Figure 3.3 Share of early leavers from education and training, France, 2010-2017 (\% of population aged 18 to 24 )

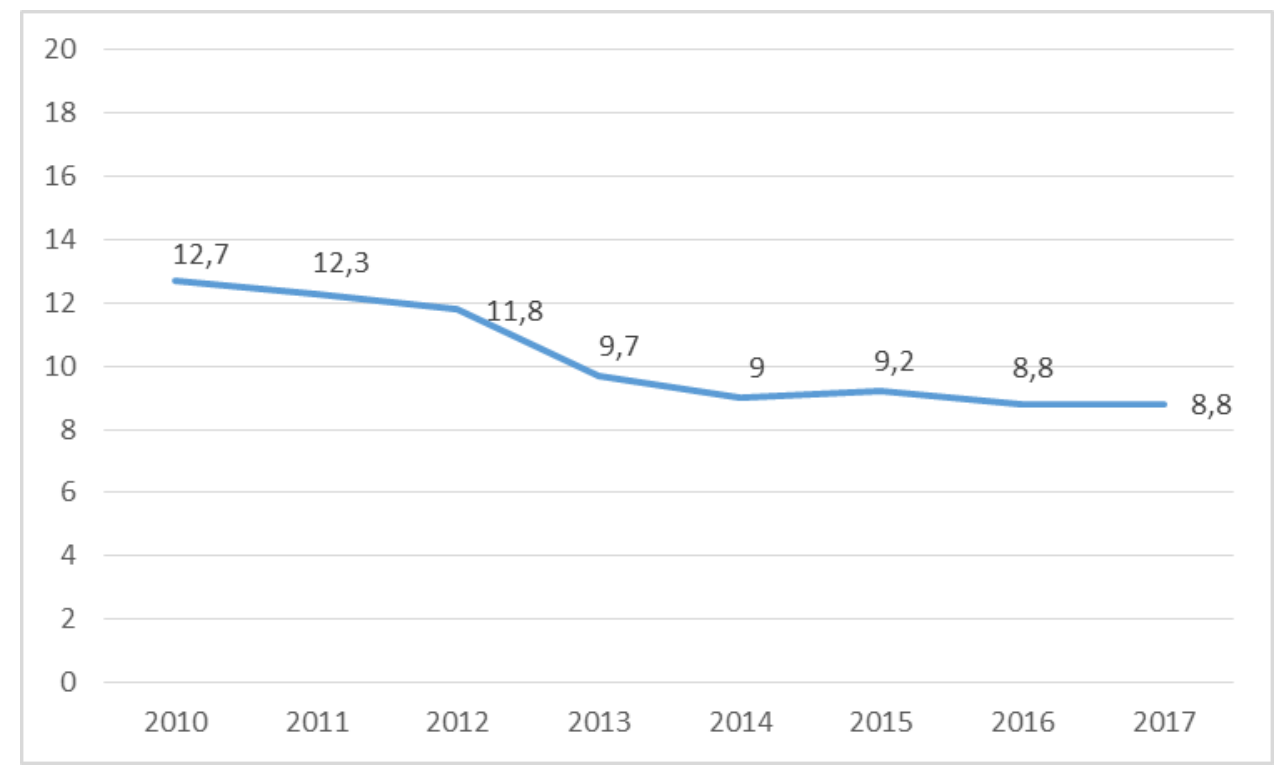

Source: Eurostat, data available at:

http://ec.europa.eu/eurostat/tgm/table.do?tab=table\&init=1\&plugin=1\&language=en\&pcode=sdg_04_10. 
In France, the decree $n^{\circ} 2010-1781$ of December 31st, 2010, fixes the minimum level of qualification which every pupil or apprentice has to reach, that is the general high school diploma, a diploma for professional ends registered in the National Directory of Certifications. Every young people who leaves the system of initial training without having the minimum level of qualification required by the law is a "leaver". So is every young person aged 16 to 25 who has left the education system.

The «Plan de lutte contre le décrochage scolaire», the fight plan against ESL, was launched in 2014 by the previous government and then Minister of Education Najat Vallaud-BelKacem. The current government aims to decrease to half of the current number of school leavers during his mandate.

In Paris Academy, many local and national policies are defined to:

- prevent the unhooking risks in establishments by activating the groups of prevention of the early school leaving (GPDS) which replace the Groups of insertion support (GAIN);

- settle the "FOQUALE" network in each of 8 territories;

- strengthen links between the "FOQUALE" network and the PSAD (inter-institutional platforms of following-up and supporting young school leavers);

- develop the inter-institutional partnerships and a complementarity in the proposed solutions;

- provide to all actors (head teachers, referents of the GPDS, the referents of action MLDS (mission of fight against the early school leaving), coordinators MLDS and DCIO) useful resources for the implementation of prevention initiatives and treatment of the unhooking;

- develop the MLDS's device of coverage;

- propose a plan to individualize the school path, since 2015, with "Parcours aménagé de formation initiale"28/Adapted trajectory of initial training, which introduces the possibility for a student to make a pause and do "activities of another type, which are apparently less academic, and which may be suitable for him and motivate more. Could be considered including activities such as civic service, routes citizen, social clauses, ${ }^{29}$ discovery courses in companies, etc. depending of needs of the young. The young person can propose it himself";

- "Devoirs faits"/Homework done, since November 2017, propose to help students in their school, to provide a study time accompanied to have their homework done. This study is free. Every child should be able to work individually, calmly, to do exercises, to repeat his

\footnotetext{
${ }^{28}$ DGESCO DREDIE, “tous mobilisés contre le décrochage scolaire, Guide mise en oeuvre du parcours aménagés de formation initiale", novembre 2015.

${ }^{29}$ The young person who benefits from social clauses is under school status but in business immersion, for a period of 6 to 12 months. At the end, he can return to his establishment (continuation in training initial) or integrate the company.
} 
lessons or to exercise his memory and sense of analysis, with the possibility of being helped when he needs it;

- a re-engagement platform on line: Come back to training: "Réviens te former" (http://reviensteformer.gouv.fr), is a platform for the 16 to 25 years old with information (video) and the possibility to talk with a counsellor.

In 2016, 98000 youngsters left school with no practical qualification (107,000 in 2015 down from 140,000 in 2010). ${ }^{30}$ Currently, the rate of 18-24 outgoing years without diploma nor solution is $9.2 \%$. It is lower than Germany (10.1\%), United Kingdom (10.8\%) and the EU average (10.7\%).

The youngsters aged 18-24 who left the education system with no baccalauréat or vocational certificate have not much chance of finding a job. They come from all backgrounds and family structures, though children from disadvantaged families predominate.

New research ${ }^{31}$ reveals regional differences that reflect social and economic circumstances dropping out is most common in areas of high unemployment such as those in the north around Amiens, in Corsica and in overseas departments. Paris, the West and the southern half of France, except for the Mediterranean edge, are among areas least affected. Boys are afflicted more than girls - for every 100 girls who drop out, there are 150 boys. Signs are visible early on: one in four primary pupils has difficulties, and $15 \%$ of these have 'severe' or 'very severe' difficulties. The high dropout rate not only means personal disaster for hundreds of thousands of youngsters but threatens French competitiveness and makes society pay a high price. In addition to a human and social cost, dropping out has an economic cost, estimated at 230,000 euros throughout the adult life of a dropout or nearly 30 billion $€$ of debt each year. ${ }^{32}$ Fifty million euro a year is dedicated to fighting early school leaving.

Specifically, in Ile-de France Region there are:

- around 26.000 and 33.000 youngsters who left school since 2013;

- digital divide between high schools of Ile-de-France $(97 \%$ of high schools connected in Paris against $41 \%$ in Seine-Saint-Denis);

- 3,700 with disabilities and only 12 high schools on 496 are today accessible;

- $20 \%$ unemployed young people at the end of their initial training.

In what concerns Paris Academy:

\footnotetext{
30 DEPP/Enquête emploi, Indicateurs MENESR prevision.

31 COMPAS étude $\mathrm{N}^{\circ} 11$ janvier 2014.

32 "French government action plan to halve school dropout", www.education.gouv.fr.
} 
- More than half districts are in favorable situation regarding the school risk of failure and unhooking.

- The diversity of the Parisian pupils and the will to make them succeed involves an adaptation of the trainings schools and various success's footbridges.

- Early school leaving concerns around 30,000 young people a year (INSEE).

- Two districts of the type "accumulation of economic, family, cultural fragilities" are in the northeast. It is about the 19 th and about the 20 th.

- The part of the young graduates among 15-24 not schooled years is in the average for the 20 th (25. $4 \%$ in metropolitan France) and of $29.5 \%$ in the 19 th.

Related to the Paris 19th District, located in the North of Paris, with more than 200000 residents, the situation is:

- The poverty rate exceeds 25 per cent and over 40 per cent in some neighborhoods (well above the national average of 14.3 per cent)

- There are single people, but also poor families, sometimes housed in a much degraded private park.

- The share of non-educated youth among the 15-24 year-olds not enrolled in school is 29.5 per cent in the 19th. (25.4 per cent in metropolitan France).

In Seine-St-Denis (93), located in the North-Est of Ile-de-France, with 1.552 million of residents:

- The share of graduates is lower than in neighboring districts.

- 30 per cent of young people have no qualifications and only 12 per cent have a degree of second cycle, against 20 per cent and 25 per cent in the Ile-de-France.

- High level of poverty (30 per cent under the poverty level), high rate of unemployment.

A study refers that "the estimated poverty rate of 60 per cent of the median income is the percentage of households that receive less than $60 \%$ of the national median income, where half of the population has superior resources and the other lower, after direct taxes and social benefits".33

\section{Italy}

At the national level, ISTAT (Istituto Nazionale di Statistica/The National Italian Institute of Statistics) uses the same definition as the European Commission to define ESL. Specifically, it means young people between the ages of 18 and 24 who have dropped out of school early without having obtained a qualification higher than a middle school certificate (obtained at the end of 8 years of compulsory education - 5 years of education ISCED level 1 plus 3 years of ISCED

\footnotetext{
${ }^{33}$ COMPAS étude $N^{\circ} 11$ janvier 2014.
} 
level 2), or who do not have a vocational qualification obtained in professional training courses lasting at least two years and who are not attending school courses or other training activities.

In Figure 3.4, recent trends in ESL share in Italy are shown, and a decrease is evident. Italy is, already, below its national target regarding early leavers from education and training, which is 16 per cent.

Figure 3.4 Share of early leavers from education and training, Italy, 2010-2017 (\% of population aged 18 to 24 )

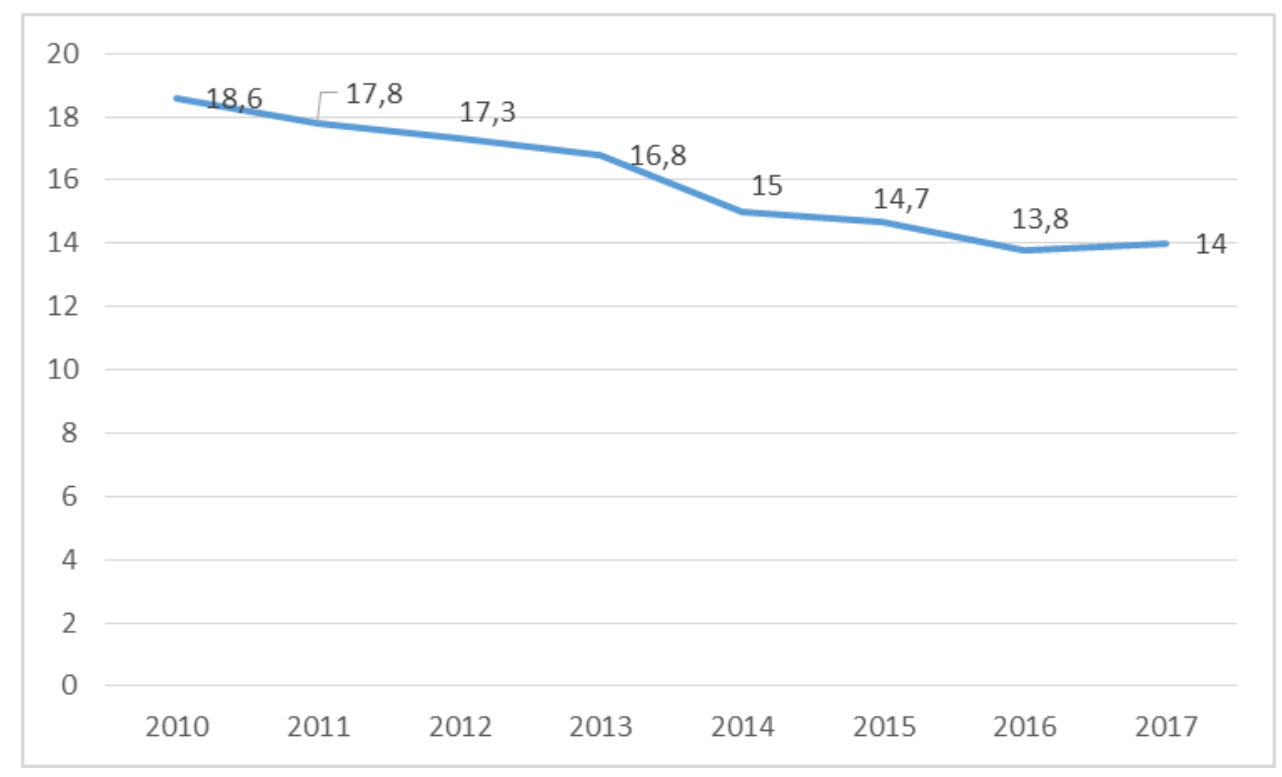

Source: Eurostat, data available at:

http://ec.europa.eu/eurostat/tgm/table.do?tab=table\&init=1\&plugin=1\&language=en\&pcode=sdg_04_10.

The ESL indicator provided by ISTAT at the national level is not available at the provincial level, therefore the Regional Institute of Economic and Social Research (IRES Piedmont) has been calculating a similar indicator for some years using some variables available from the ISTAT Labour Survey. Even though not completely comparable, the two indicators have demonstrated a similar behaviour in recent years.

Local definition of ESL used in Piedmont / province of Cuneo: fraction of residents aged 18-24 years having more than the diploma at the end of the first cycle (middle school) and not participating in training courses of more than two years and not enrolled in school or training courses. The indicator is calculated using the variable "highest level of education" (the variable that classifies the "ISCED 2011" qualifications is still not available). 
The ESL indicator presents a break in the historical series in 2014: from that year onwards a change in the operational definition of the indicator no longer counts among the dropout of people who have some types of short term qualification. Therefore, since 2014 the reduction of the ESL indicator also depends partly on this difference which has been introduced.

The Italian school system has been the subject of a series of structural reforms since the end of the 1990s. The latest reform, introduced with the law 107 of 13 July 2015 ("The Good School Law"), has a strong programmatic nature and introduces numerous contributions in the fight against early dropout, among which we must highlight:

- a strong push towards didactic - methodological innovation, through the massive use of ICTs and the methodological approach of "didactics for skills" (laboratory teaching and active involvement of students);

- the increase in the number of staff of each school, also aimed at reducing the number of students per class;

- the push for schools to make greater use of the margins of didactic autonomy and flexibility within the curricula already granted with the previous reforms, in particular with Presidential Decree 275/99;

- more space for "transversal" learning fields: education aimed at correct lifestyles, active citizenship, environmental education;

- the introduction of a bonus reward that school directors can provide to the most active teachers and that contribute to raising the quality of the school (above all, the level of those committed to achieving significant methodological and innovation in the curriculum);

- the possibility for school managers to choose and hire a certain number of teachers from their own school with a three-year contract, selecting them from a list of state-qualified teachers available in a given area;

- alternation between school and work, which is strengthened in technical and professional education and introduced for the first time in high school education.

- In the last three years of high school (ISCED 3), each student must be engaged for at least 400 hours (which is reduced to 200 for high school students) in activities involving direct contact with the world of work;

- internships in companies, visits to production companies, training modules, professional orientation activities, etc. 
Other structural reforms are worth mentioning. The Fund for the fight against educational poverty for minors was established by Law no. 208 of 2015, art. 1, paragraph 2392 and made operational with the signing of a Memorandum of Understanding between MIUR (Ministry of Education) and ACRI (National Association of Bank Foundations). The Fund is intended "to support experimental interventions aimed at removing the economic, social and cultural obstacles that prevent the full use of educational processes by minors". The Fund is managed by the social enterprise Con i Bambini and is powered by bank foundations. A steering committee composed of the government, foundations, the third sector and authoritative institutions in the educational field defines the lines of intervention.

The fund will have a total of $€ 120$ million a year for three years and at the moment three calls for proposals have been published:

- 2016: "Proposals for Childhood" (target: 0-6 years) and "Proposals for Adolescence" (1117 years) - 115 million euros between the two tenders.

- 2017: "Proposals for New Generations "(5-14 years) - 60 million euro.

It is still early to evaluate its impact, but the institution of the Fund is an important experiment in making operative a comprehensive strategy to combat educational poverty of minors on a national scale from the perspective of prevention, fuelled and inspired by the best territorial experiences and with long-term effects.

In what concerns regional policy, we underline the following in the Veneto Region and in Piedmont.

The policy of the Veneto Region for the recovery of the ESL

The Region of Veneto on the basis of the DGR n. 1255/2016 supports initiatives and projects for the implementation of training programs for the recovery of school drop-out through the "Outof-School" Program for 2016/17 and 2017/18. The Region intends to support the recovery efforts of the "missing", focusing on those who have abandoned training and education, even if they are still under 18 years. Acting on this target allows leveraging of the recent detachment from the school system to facilitate the inclusion in innovative and experimental projects that combine general training, professional training, creative and artistic activities and professional orientation, with the dual purpose of supporting the entry of young participants in the labour market and strengthen their role as active citizens in society. 


\section{Two good practices at regional and local level}

At the regional level, an interesting didactic-experimental research-action path is constituted by the project "The School draws the future", funded by the San Zeno Foundation and addressed to primary and secondary school students. It was launched in September 2015 and will end in August 2018. Indirect beneficiaries are teachers, families, laboratory experts, voluntary groups and associations for extra-curricular activities. The general aim is to take care of new generations and their potential, and to support a good school capable of interpreting the needs of young people. Teachers are asked to design interdisciplinary courses based on "FARE" ("TO DO") which refer to art, music, crafts, coding and science: these are educational workshops during curricular hours, with the participation of external experts and the collaboration of parents, volunteers and associations. All this is supported by annual training plans for teachers, in-depth studies with families, open classes for and with parents. The project also makes use of the contribution of the Italian Institute for Evaluation for Monitoring and Evaluation activities.

In the territory of Villafranca attention in the fight against the educational dropout is represented by an operative protocol that the local council in collaboration with the schools across the territory has stipulated for the prevention of social problems manifested in the scholastic field; the priorities include "the promotion of interventions to monitor, prevent, remove and / or combat the phenomenon of early school leaving, as well as any gaps which result in situations that can prejudice the potential for growth and development of the personality in children and adolescents ". The protocol provides a space for defining the fundamental concepts in terms of protection of minors, among which there is compulsory schooling and a specification of the violation of this obligation in its various meanings such as avoidance and dropout. This means the school is a "privileged observatory for the primary prevention of social malaise and a natural place for the educative growth of the minor". The intervention methodologies follow an integrated and interdisciplinary approach in close collaboration with the competent Services. Furthermore, at Villafranca, the commitment to the fight against school dropout is manifested in supporting local initiatives such as the "Work in Progress" Project (see below, in the section of local initiatives and practices).

\section{The Piedmont Region's policy to combat early school leaving and academic success}

The Piedmont Region, within the framework of education and training policies, recognizes the prevention and recovery of dropout and early school leaving among its priority objectives. Since 
2006 it has instigated joint experimental paths with the regional school office through resources made available to the latter by the Ministry of Education (MIUR). The continuation of this collaboration has been confirmed by the latest regional resolution (DGR of 12 June 2017, No. 305171), which pays particular attention to the promotion of systemic actions to support areas at risk with high levels of immigration and against school dropout, including the continuation of the territorial laboratories aimed at the success of the pupils who repeat more than once the first level secondary school (LAPIS Project) for the 2016/17 school year.

Also worthy of note is the Piedmont Orientation Objective (Obiettivo Orientamento Piemonte), a regional flagship project which aims to set up and standardize good practice on school orientation that has been experimented with for some time in the individual provincial territories. The initiative has regional funding of 4.5 million euros from the European Social Fund for the 2016-2019 three-year period and is aimed at a potential basin of 378,000 young people (12-22 years) who attend educational institutions or training institutions professionally, that are looking for a job or have dropped out of school. Among the actions, it has activated a network of 169 public and free information points throughout the region, 25 of which in the province of Cuneo. Over 46,000 young people were involved in the first year of activity, of which approximately 7,000 were in the province of Cuneo.

The province of Cuneo is very active in the fight against school dropout and there are numerous players involved more and more in the network in prevention measures, on the road or for reintegration, often of an innovative nature. There have been numerous calls for proposals and initiatives promoted by the bank foundations active in the territory, including in the field of innovative teaching, guidance, training for teachers and trainers.

In what concerns the rates of ESL in Italy and regions of the project, the discrepancy between the geographical areas is evident by comparing the southern and island regions, which are much more affected by school leaving than the others: the Centre-North, as a whole, has an ESL rate of $14.1 \%$ compared to $21.4 \%$ in the South-Islands (ISTAT and CNEL, 2014) 34 . An educational poverty index (Save the Children Italia, 2014) ${ }^{35}$ has recently been calculated based on school

34 Istat and CNEL (2014) Rapporto BES 2014. Rapporto sul benessere equo e sostenibile in Italia https://www.istat.it/it/files/2014/06/02 Istruzione-formazione-Bes2014-2.pdf.

35 Save the Children (2014) La lampada di Aladino. L'indice di Save the Children per misurare le povertà educative e illuminare $\quad$ futuro dei bambini il in https://www.savethechildren.it/sites/default/files/files/uploads/pubblicazioni/la-lampada-di-aladino.pdf. 
and extracurricular indicators, according to which some Italian regions are very problematic: Campania, Puglia, Calabria, Sicily, Molise, Abruzzo, Sardinia.

The gender differential also deserves attention: women tend far less than men to abandon their studies (20.2 per cent male ESL rate vs. 13.7 per cent female) and reach higher levels of education than men (graduation rates between 30-34 year-olds: 27.2 per cent females vs. 17.7 percent males) (ISTAT and CNEL, 2014) 36 . Not to be overlooked is the third 'discriminating

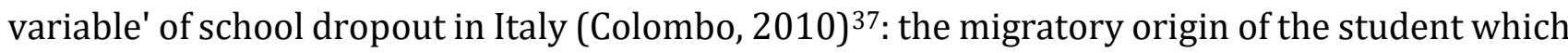
here coincides with non-Italian citizenship. According to the latest ISMU-MIUR Report, foreign students have a rate of delay triple that of natives (36.3\% CNI pupils vs. $11.2 \%$ Italians); a repeat rate that is double (12.1 per cent CNI pupils vs. 7.2 per cent Italians) and a non-admission examination rate for the first cycle which is almost four times that of Italian students $(8.6 \% \mathrm{CNI}$ pupils vs. $2.7 \%$ Italians) (Santagati and Ongini, 2015) ${ }^{38}$. But what is most serious is the widespread absence of the youth population in the training courses beyond the diploma: in Italy only $21.4 \%$ of young people of $20-29$, according to the OECD.

\section{Piedmont and the province of Cuneo}

According to the most recent data provided by Ires Piemonte (Piedmont Educational Observatory) (Osservatorio Istruzione Piemonte):

- In Piedmont (North-West Italy) in 2016 the ESL are 10.2 per cent, which is lower than the national average (13.8 per cent) and close to the Europe 2020 targets. The value is continuously improving: it was 12.6 per cent in 2015 and has more than halved compared to 2004 (22.6 per cent).

- The phenomenon affects males to a greater extent (16.6 per cent in 2015) than females (8.4 per cent in 2015) (Figure 3.5).

\footnotetext{
36 Istat and CNEL (2014) Rapporto BES 2014. Rapporto sul benessere equo e sostenibile in Italia https://www.istat.it/it/files/2014/06/02 Istruzione-formazione-Bes2014-2.pdf.

${ }_{37}$ Colombo M. (2010) Dispersione scolastica e politiche per il successo formativo, Erickson, Trento.

38 Santagati M., Ongini V. (2015) Alunni con cittadinanza non italiana. Tra difficoltà e successi. Rapporto nazionale a.s. 2013/2014, Fondazione ISMU http://www.ismu.org/wp-content/uploads/2015/03/Rapporto-CNI-Miur Ismu2013 14.pdf.
} 
- The province of Cuneo (South West Piedmont) has held the negative record at regional level in terms of school dropout for many years, but in recent years the figure has progressively improved.

- According to the most recent estimates the ESL represent 10.6 per cent in the two-year period 2015-2016.

- Even considering the changes introduced in 2014 to calculate the value, Cuneo showed the best recovery compared to the other seven provinces in Piedmont: in 2009 it had the highest share of ESL in Piedmont (25.9 per cent compared to a provincial average of 19.8 per cent), in 2012-2013 this was 17 per cent, in 2014-2015 11.9 per cent and, finally, 10.6 per cent in 2015-2016, in line with the regional average and close to the Lisbon objective of 10 per cent.

As previously mentioned, it should be noted that a change was introduced in the operational definition of the ESL indicator in 2014, which excludes from the holders of some types of short term qualification from the count of the "dropouts". Therefore, the reduction in the ESL indicator in recent years also depends partly on this change.

Figure 3.5 ESL trend in Piedmont, 2004-2016

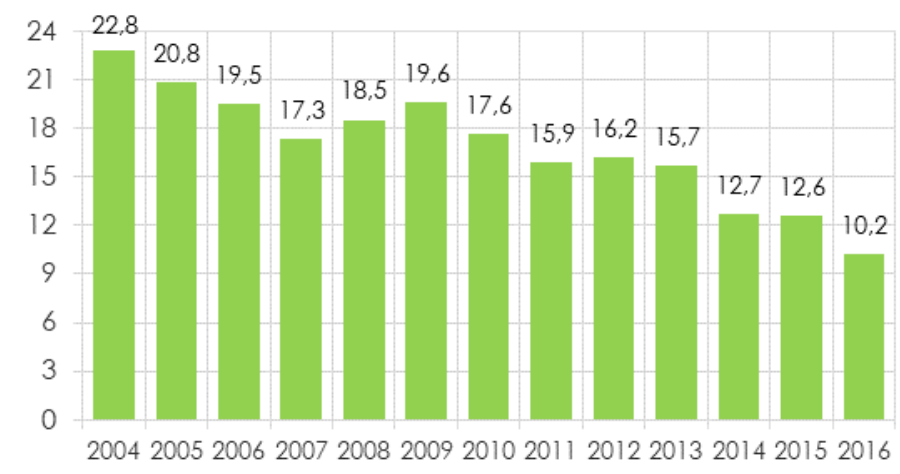

Source: Eurostat, data processing IRES Piedmont

\section{Villafranca (Verona)}

The data on school dropout and school dispersion in the territory of Villafranca (Verona) follows the regional data. There are 27,073 young people of this age group who have left the school system early without obtaining education qualifications higher than the middle school certificate or professional qualifications obtained in courses lasting at least 2 years and not attending school courses or training activities. The projections of these data to the provincial Veronese 
dimension indicate that there are about 5,000 young people aged 18 to 24 who are classed as early school leavers, or as exiting prematurely from the training system. The Veneto situation is therefore better than the Italian average (15 per cent).

In the area of Villafranca, from the consultation of POFT and RAV of the middle school institutes and the Secondary High Schools, it emerges that only a minimum percentage of students is not admitted to the next class, in line with the regional and national average trend. The institutes maintain a high level of attention towards students at risk of dropout by implementing projects to safeguard them and guide them in their training process. The cases of dropout are due to transfers of the original nucleus of foreign students for work needs or for educational reorientation.

\section{Portugal}

In Portugal, ESL means non-completion of compulsory education while having the ages established by the law to be enrolled in it. Put it in another words, every youngster that is not enrolled in any school or training level and have not finished compulsory education while in the age for it, is an early school leaver. Statistically speaking, early school leaving is measured following the definition of leavers from education and training as in Europe and Eurostat.

Also due to the listed policy initiatives, the values of ESL have been decreasing over the years (see Figure 3.6). However, the huge fall of this indicator has not been enough to erase the gap that still exists between this rate in Portugal and the European rate and the path that is still needed to reach the target for 2020 (the national target is the same as ET 2020: 10 per cent). Although the rate for EU is 10.6 per cent, in Portugal the ESL/ELET share still is 12.6 per cent. 
Figure 3.6 Share of early leavers from education and training, Portugal, 2010-2017 (\% of population aged 18 to 24)

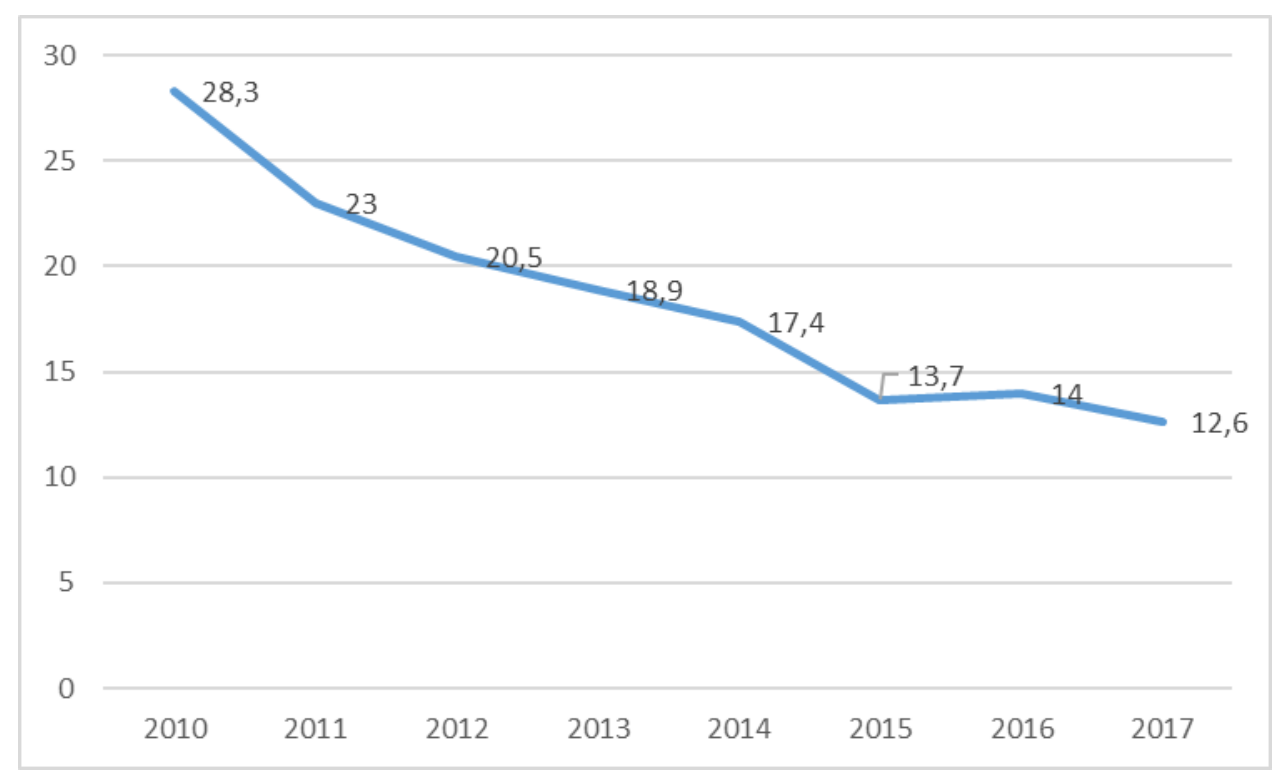

Source: Eurostat, data available at:

http://ec.europa.eu/eurostat/tgm/table.do?tab=table\&init=1\&plugin=1\&language=en\&pcode=sdg_04_10.

We highlight that the rate for women is, already, below 10\%; the male share is higher than global:

\section{3 per cent.}

Table 3.1 Share of early leavers from education and training, Portugal, 2001-2011-2017 (\% of population aged 18 to 24), by sex

\begin{tabular}{l|c|c|c|c|c}
\hline & 2001 & \multicolumn{2}{|c|}{2011} & \multicolumn{2}{|c}{2017} \\
\hline \multirow{3}{*}{ Total } & PT & PT & EU & PT & EU \\
Men & 44.3 & 23.0 & 13.4 & 12.6 & 10.7 \\
Women & 51.6 & 28.1 & 15.2 & 15.3 & 12.2 \\
\hline
\end{tabular}

Source: PORDATA \& The Education and Training - Monitor 2017.

ESL in Portugal is unequal. As we get near the city capital and the surroundings (AML), where Amadora is located, the share decreases and the values come close to the national share. The highest rates were found for Azores and Madeira in 2011 and only are available for Azores in 2017, remaining higher than the national share. 
Table 3.2 Share of early leavers from education and training, Portugal, 2011-2017 (\% of population aged 18 to 24 ), by sex and region

\begin{tabular}{lccc|cccc}
\hline & \multicolumn{3}{c}{$\mathbf{2 0 1 1}$} & \multicolumn{4}{c}{$\mathbf{2 0 1 7}$} \\
\hline Region & Total & Male & Female & Total & Male & Female \\
\hline Portugal & 23.0 & 28.1 & 17.7 & 12.6 & 15.3 & 9.7 \\
\hline North & 22.6 & 28.4 & 16.6 & 12.8 & 16.4 & 9.1 \\
Centre & 20.3 & 25.9 & 14.5 & 10.5 & 13.8 & 7.1 & \\
AML & 22.8 & 25.6 & 20.0 & 10.8 & 9.9 & 11.7 & \\
Alentejo & 20.1 & 25.8 &.. & 12.9 & 18.5 &.. &.. \\
Algarve & 24.9 & 29.6 &.. & 17.1 &.. &.. &.. \\
Azores & 43.8 & 52.1 &.. & 27.8 &.. &.. &.. \\
Madeira & 30.6 & 38.9 &.. &.. & &.. \\
\hline
\end{tabular}

Source : INE, National Statistical Institute.

Notes: this indicator corresponds to the former ESL, it is used in the monitoring of Europe 2020 and it is calculated according to the methodology of Eurostat; '..' not available.

In Portugal, currently there is not a global strategy towards ESL in specific, like the ones existent in other countries, as Belgium, Bulgaria, Spain, Malta, the Netherlands, or Austria, where they correspond closely to the concept of a comprehensive strategy as defined by the Recommendation of the Education Council, ${ }^{39}$ although a Plan to Prevent ESL has been implemented in 2004 and several other strategies to tackle some of the underlying problems of ESL.

On that matter, it is worth mentioning the plans to promote success at school which, by dealing with one of the predictors of ESL, may have contributed to reduce the ESL. Also, some programs aimed to promote closer relationships between schools and the communities (like Programa Escolhas or TEIP), therefore trying to re-engage families and youth in schools. We list some of the national initiatives since the beginning of the 2000's:

- 2004 - Programa Escolhas (Choices Programme)

- 2006 - 70 Measures to Improve the Quality of Public School Education (full-time school, extra school time and study support...)

- 2009 - Extension of compulsory education (up to the age of 18 or 12 years of schooling)

- 2009 - 'Programa Mais Sucesso Escolar' (Program more School Success)

${ }^{39}$ European Commission/EACEA/Eurydice/Cedefop (2014), Tackling Early Leaving from Education and Training in Europe: Strategies, Policies and Measures, Eurydice and Cedefop Report. Luxembourg: Publications Office of the European Union. 
- 2012 - Organizational and curricular revision of basic and secondary education (homogeneity classes; anticipation of vocational education differentiation: vocational courses in basic education)

- 2013 - Youth Guarantee Implementation Plan - Portugal (until 30 y/NEET)

- 2016 - National Program to Promote Success at School, under which schools could (and had) applied with different initiatives.

The National Program to Promote Success at School, which is under way, is based on the principle that each educational community is the one that best know their contexts, their difficulties and potentialities, and is therefore better prepared to devise strategic plans of action, designed at the level of each school, with the aim of improving student learning. The program is designed to fund strategical action plans created by each group of schools. Among other initiatives, the program aims at enabling schools to design organizational and curricular solutions to improve student's learning and to present them to the Ministry of Education. ${ }^{40}$ This initiative was created to prevent school failure and the number of participating schools has exceeded expectations. ${ }^{41}$

\section{Romania}

The Romanian Ministry of Education has adopted the EU definition of early school leaving: youngsters considered early school leavers are those people aged between 18 and 24 who graduated secondary school (8th grade/ISCED 2) or less and are not enrolled in any type of education or training.

In Figure 3.7, the share of early leavers from education and training in Romania, between 2010 and 2017, decreased, although not much. In 2014, there has been a time series break and it may explain the inversion of the trend to decrease. From 2015 until present, the decrease is visible again, although the values are far from the ET 2020 (national target is 11.3 per cent).

\footnotetext{
${ }^{40}$ According to what is explained in the Resolution of the Council of Ministers that creates it, the Resolução de

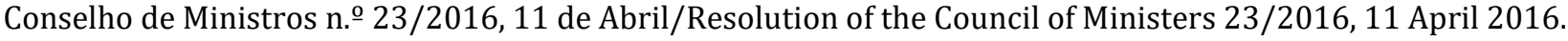

41 European Commission (2017), Education and Training Monitor 2017, Luxembourg: Publications Office of the European Union.
} 
Figure 3.7 Share of early leavers from education and training, Romania, 2010-2017 (\% of population aged 18 to 24)

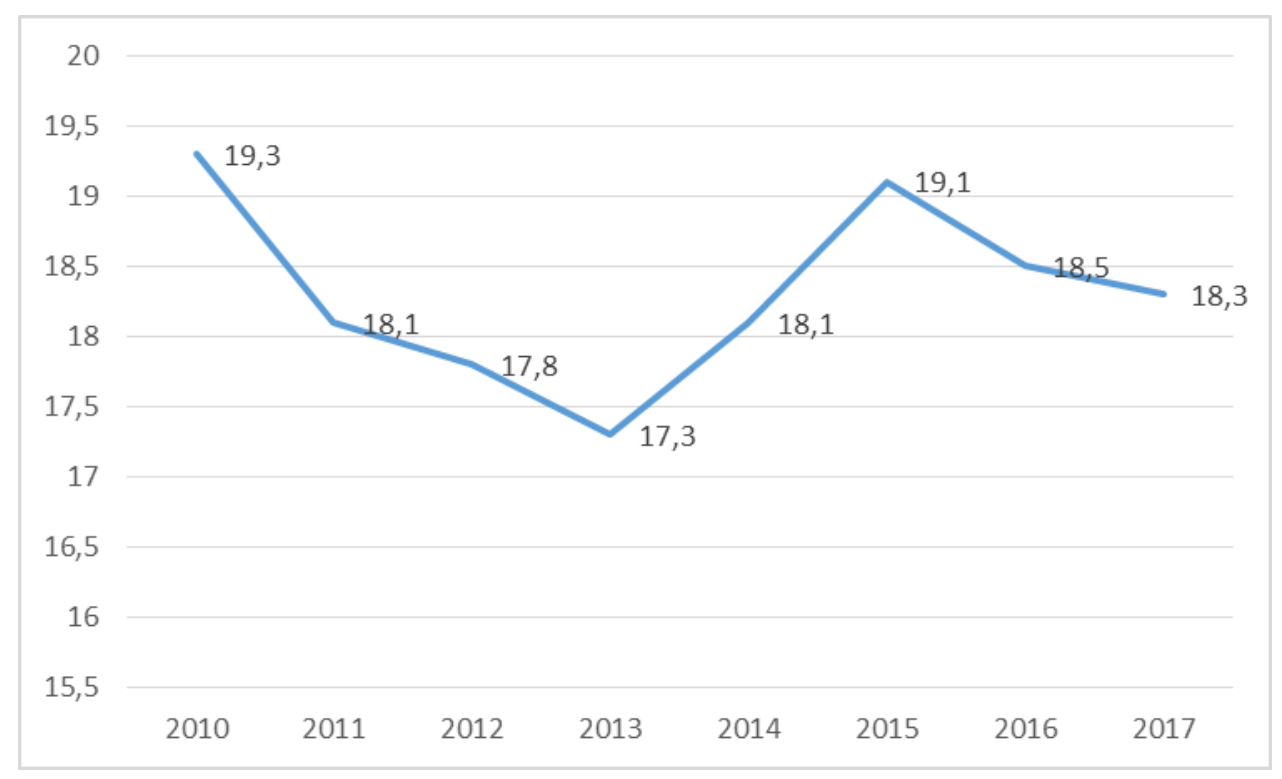

Source: Eurostat, data available at:

http://ec.europa.eu/eurostat/tgm/table.do?tab=table\&init=1\&plugin=1\&language=en\&pcode=sdg_04_10.

According to the Ministry of Education and the National Statistics Institute, the rate of school dropout is given by the difference between the number of pupils enrolled at the beginning of the school year and the number of pupils graduating the same school year.

Another definition used in Romania is the one included in the internal regulations of preuniversity education - a pupil is in a situation of school dropout when he/she does not attend the regular classes of compulsory education and is more than 2 years older than the age assigned for that specific grade.

The Ministry of Education's Strategy for Reducing Early School Leaving in Romania involves:

\section{Prevention instruments}

- Facilities for disadvantaged children

- Extended educational and training opportunities in order to increase graduating 10th grade

- Support for schools in rural areas

- Supporting pupils of different ethnical background / with foreign mother tongue

- Collaborations between parents and school

- Supporting pupils with low school results

- Developing professional training opportunities for pupils exposed to ESL.

Intervention instruments - school level 
- Making the school a pleasant learning environment

- Creating well developed methods of identifying the first signs of dropout risk

- A good relation with parents, the community, local associations, NGOs, employers in order to facilitate the communication and support for families in risk categories

- Permanent training for teachers in order to tackle possible dropout cases

\section{$\underline{\text { Intervention instruments - individual level }}$}

- Mentoring

- Individually oriented teaching techniques, especially for disadvantaged pupils

- Counselling - vocational, professional

- Financial support for pupils with financial problems

\section{Intervention instruments - compensation (reintegration)}

- Second Chance program, transition classes

- Psychological, social, financial, educational support for youngsters with difficulties

Almost 366,000 children between 3 and 17 year-olds were not engaged in any type of education in 2013. Although the dropout rate is decreasing at all school levels, in only one school year (2012-2013), almost 24.400 children dropped out of primary and secondary school.

Difficulties exist when wanting the real measure of the phenomenon: the official data do not include children who were never enrolled in the educational system or who abandoned school in the previous years; the school dropout definition is not unitary and some apparent cases of repeating the school year are covering actual cases of dropout.

During school year 2014-2015, the rate of school dropout reached 2\% for primary and secondary school and 3.5\% for high school and vocational education, almost 1\% higher than the previous year.

More than half of Romanian children (51\%) are at povery risk or social exclusion.

Only $42 \%$ of Roma children aged 6-15 attended kindergarten, compared to $87 \%$ of the children of other ethnic groups living in the same environment. And $22 \%$ of Roma children do not attend school, compared to $6 \%$ in the case of other ethnicities.

The children aged 7-10 who were not enrolled in the school system, by year: $2013-64,711 ; 2014$ - 79,896; 2015 - 79,565. Children aged 7-17 who were not enrolled in the school system, by year: 2013 - 241,553; 2014 - 272,121; 2015 - 282,017. 
Overall, the rate of ESL in Romania increased 1.5 percent in 2016 (from 17.4 to 19 per cent), while in the EU, the tendency is one of decrease (from 13 to 11 per cent).

Other relevant information shall be highlighted. During the school year 2014/2015, a total of 18,798 cases of violence in schools were reported to the Ministry of Education, and 73 per cent of the children declare that they have witnessed at least one bullying situation inside their school and 58 per cent of them were witnesses of bullying inside their classroom.

\section{UK}

As in all other countries, we start the analysis with the share of early leavers from education and training in the UK, according to statistics from Eurostat, and showing that share is near ET 2020. There is no national target on National Reform Program in the UK.

Figure 3.8 Share of early leavers from education and training, UK, 2010-2017 (\% of population aged 18 to 24)

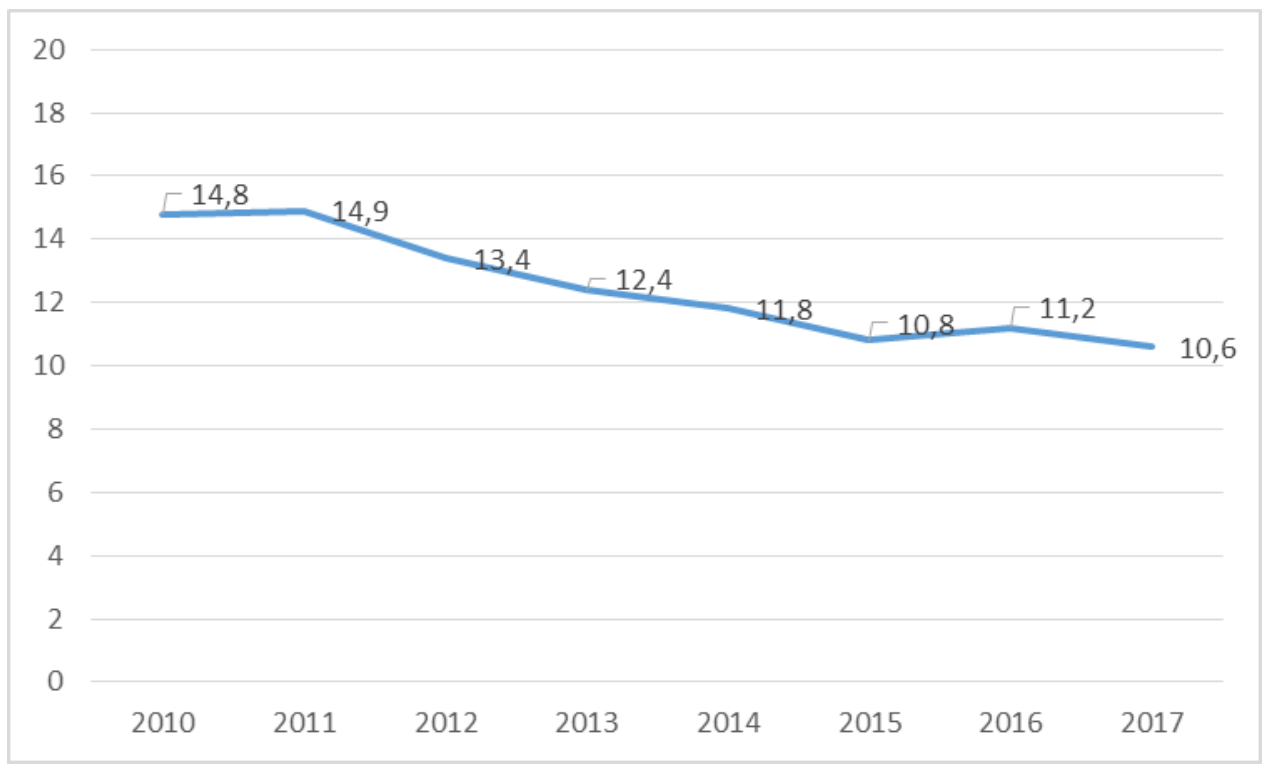

Source: Eurostat, data available at:

http://ec.europa.eu/eurostat/tgm/table.do?tab=table\&init=1\&plugin=1\&language=en\&pcode=sdg_04_10.

There is no official definition of early school leaving in the UK. National statistics collect information from a variety of sources and published by the Department of Education (DfE) ${ }^{42}$ and by other government departments depending on the focus of the statistical data and the purpose (e.g., school attendance or employment statistics). Furthermore, it is difficult to compare data

42 The UK has a devolved system such for which each Region comprising the United Kingdom (England, Wales, Scotland and Northern Ireland) has its own education department. Since Below 10 UK includes only partners in England, the statistics provided here refer only to England. 
for a number of reasons. The most obvious one is related to the age range used which can be 16 $17,16-18,18-24$, etc. To this effect it is important to note that while the Department for Education's statistical data refers to 16-17 years old, the latest Commons Library Briefing, 28 December 2017 (UK Parliament, 2017) makes use of a wider age range 16-24.

Furthermore, in regard to 14-16 years old, the UK terminology does not refer to early school leaving. In this case statistical data referring to school exclusion and attendance were used as a proxy for ESL. The information provided here for both the national and local figures is drawn from a number of documents since no single source provided all the information required.

According to Participation in Education, Training and Employment by 16-18 olds in England: End 2016 (DfE, 2017) ${ }^{43}$, participation in education continues to rise while the number of NEETs continues to fall (see Figure 3.9 and 3.10).

Figure 3.9 Participants in education and WBL (work based learning) by academic age, England

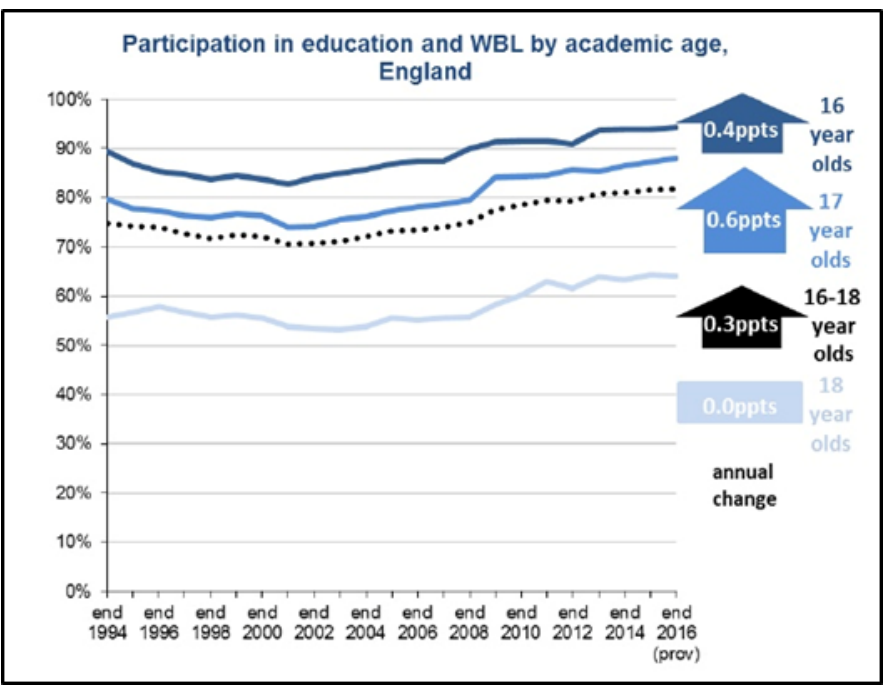

Source: DfE, 2017a: 1

43 Department for Education (2017a) Participation in Education, Training and Employment by 16-18 olds in England: End 2016. London: DfE 
Figure 3.10 Proportion NEET by academic age, England

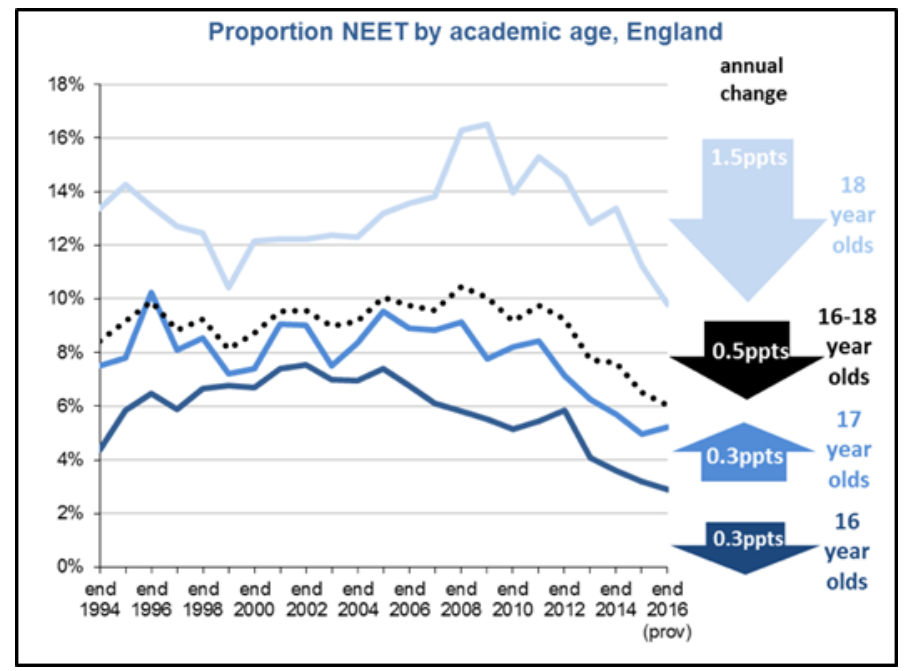

Source: DfE, 2017a: 1

The latest statistics proportion of 16-17 year olds recorded in education and training, June 2017 (DfE, 2017a) report the following national data for England:

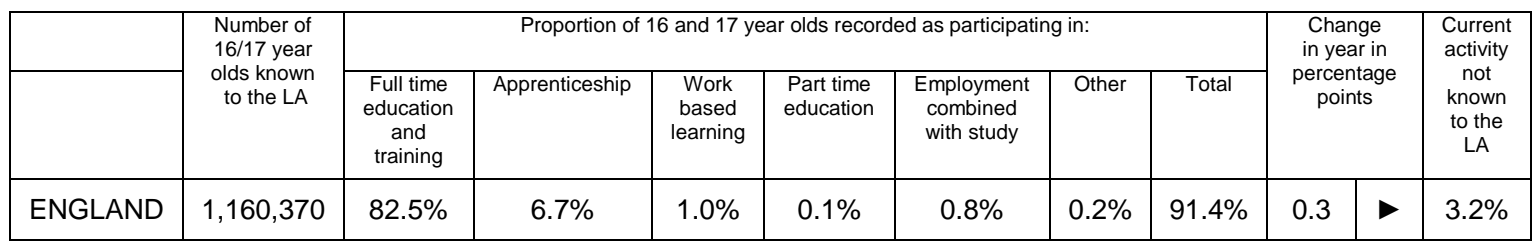

For the same year group, the figures for 16-17 year olds not in education, employment and training are as follows:

\begin{tabular}{|c|c|c|c|c|c|c|c|}
\hline & $\begin{array}{c}\text { Number of } \\
16 \text { and 17 } \\
\text { year olds } \\
\text { known to the } \\
\text { local } \\
\text { authority (1) }\end{array}$ & $\begin{array}{c}\text { Total } \\
\text { number } \\
\text { NEET } \\
\text { (inc not } \\
\text { known) }\end{array}$ & $\begin{array}{c}\text { Proportion } \\
\text { NEET } \\
\text { (inc not } \\
\text { known) }\end{array}$ & $\begin{array}{c}\text { of which } \\
\text { known to be } \\
\text { NEET }\end{array}$ & $\begin{array}{c}\text { of which } \\
\text { activity not } \\
\text { known }\end{array}$ & $\begin{array}{c}\text { ppt change } \\
\text { in overall } \\
\text { NEET } \\
\text { measure } \\
\text { since } 2015\end{array}$ & \\
\hline England & $1,155,350$ & 69,540 & $6.0 \%$ & $2.8 \%$ & $3.2 \%$ & -0.5 & \\
\hline
\end{tabular}

It is to be noted as different documents from the same department for similar years provide different 'number of 16-17 year olds known to the local authority'. This could depend on the time of data collection and the multiple sources required in compiling the information. 


\section{$\underline{\text { Persistent absence }}$}

Since one of the factors which can lead to ESL is 'persistent absence' this category was used as a proxy to show the extent of the situation in England. The latest available data is for the 2015-16 school year and it shows an overall increase from $10.3 \%$ in 2015 to $11.4 \%$ in 2016 . As the document states (DfE, 2017d: 4), 'Secondary schools have the higher rate of persistent absence, 13.4 per cent of enrolments, compared to 10.0 per cent of enrolments in primary schools.'

\section{Local data}

Partner schools and organisation for Below $10 \mathrm{UK}$ are located in the following Local Authorities (LAs): Northamptonshire (cluster of schools and organisations in Northampton and Wellingborough), Central Bedfordshire and Peterborough. To be noted that Peterborough and Central Bedfordshire belong to the same region, that is east of England. Northamptonshire belongs to the East Midlands Region. Recent report shows the following data for the three LAs.

Table 3.3 Percentage of 16-17 years old not in education or training for the three LAs

\begin{tabular}{|l|l|l|l|l|l|l|l|}
\hline & $\begin{array}{l}\text { Number of } \\
16 \text { and 17 } \\
\text { year olds } \\
\text { known to } \\
\text { the local } \\
\text { authority (1) }\end{array}$ & $\begin{array}{l}\text { Total } \\
\text { number } \\
\text { NEET } \\
\text { (inc not } \\
\text { known) }\end{array}$ & $\begin{array}{l}\text { Proportion } \\
\text { NEET } \\
\text { (inc not } \\
\text { known) (\%) }\end{array}$ & $\begin{array}{l}\text { of which } \\
\text { known } \\
\text { to be } \\
\text { NEET }\end{array}$ & $\begin{array}{l}\text { of which } \\
\text { activity } \\
\text { not } \\
\text { known } \\
\text { (\%) }\end{array}$ & $\begin{array}{l}\text { ppt change } \\
\text { in overall } \\
\text { NEET } \\
\text { measure } \\
\text { since } 2015\end{array}$ \\
\hline England & $1,155,350$ & 69,540 & 6.0 & 2.8 & 3.2 & -0.5 & - \\
\hline Central Bedfordshire & 5,760 & 340 & 5.9 & 2.1 & 3.8 & 1.0 & $\boldsymbol{\Delta}$ \\
\hline Peterborough & 4,650 & 310 & 6.6 & 4.1 & 2.5 & 0.7 & $\boldsymbol{\Delta}$ \\
\hline Northamptonshire & 16,330 & 1,100 & 6.7 & 3.5 & 3.2 & -1.1 & $\boldsymbol{\nabla}$ \\
\hline
\end{tabular}

\section{Northampton}

Northamptonshire has published their 'Early Help Northamptonshire Strategy 2015-2020' which aims to "enable children and families to access appropriate support as early as possible so that they can maintain their quality of life, prevent any problems getting worse and feel stronger, happier and more confident' (2015:3) in which ESL is identified as an issue with school exclusion and NEET (not in education or training). The statistical narrative sets out that: ${ }^{44}$

44 The full document can be seen at http://www.northamptonshirescb.org.uk/about-northamptonshiresafeguarding-children-board/publications/nscb-business-docs/early-help-strategy/. 
- 'Too many children are excluded from Northamptonshire schools: in 2012/13 0.2\% of Northamptonshire's secondary school population were permanently excluded compared to $0.03 \%$ of our nearest statistical neighbour. $6.4 \%$ of secondary school population had a fixed term exclusion (compared to 5.13\% of nearest statistical neighbour) (2015:8).

- '5\% of our young people aged 16-18 were NEET at the end of 2014. This compares to 1.9\% in our statistical neighbour local authority' (2015:9).

\subsection{Local initiatives and practices}

In this section we report the local initiatives reported by all partners, regarding recent national and local strategies/policy/good practices in each to tackle early school leaving and failure and/or to promote success at school.

First and foremost, we highlight the diversity of initiatives when taking the overall context into account. From country to country, depending on the kind of analysis unit we consider, we have examples, presented in this section, unfolding in: a) public policies and employment and education programs; b) national strategies both preventing ESL and facilitating and supporting early leavers' return to school; c) support for sustainable professional projects; projects located within or outside schools; d) initiatives targeted at different phases of the school path (pedagogy, extra-curricular activities, orientation and internships); e) actions on domains of reinforcement of self-esteem and motivation; f) initiatives targeting different ages; g) schools for parents; $h$ ) investment in improvement school equipment; i) initiatives to tackle people and community poverty.

\section{Croatia}

Croatia reported three initiatives tackling ESL: the PERLS project, Public discussions and Youth Guarantee.

Regarding PERLS project, it was implemented in 2016-2017. The consortium of schools had the opportunity to work with students and principals, as well as with teachers and educators, on prevention of ESL. The methodology used to prevent ESL and re-engage students were educational meetings and conferences for educators and for students. The main results were defining main signs of ESL, development of new models of support for ESL and professional conferences in ESL. 
The public discussion, in May 2015, is associated with the ESL being called "quiet epidemic": the society in general tackle the phenomenon. The methodology used to prevent ESL and re-engage students was of public discussions in organizations and schools. Main results were defining the term, defining risks of ESL and raising awareness on ESL.

The Youth Guarantee, in 2017, aimed at engage young people and NEET group. The methodology consisted in public policies, employment and education programs. The project is still under way. According to what can be read in Education and Training Monitor 2017 Summary, page 12/13, "the very low early school leaving rate is among the main strengths of Croatia's education system". Also, that a Strategy for Education, Science and Technology and the associated reform is under way.

\section{France}

The French government defines two strategies to fight against ESL: 1) to prevent ESL more effectively; 2) to facilitate the return to school for the youngsters by setting up special establishments to welcome "school leavers", re-motivate and support them towards a "going back" to studies and a sustainable professional project.

Therefore, to prevent ESL, an action plan is underway and is called "All mobilized for overcoming the early school leaving". The plan has the following levels.

\section{Individual:}

- a plan for prevention and fighting absenteeism, the orientation of the pupils in the service of the school perseverance;

- a plan to individualize the school path, with "Parcours aménagé de formation initiale"; 45

- a personal support, creation of a "referent of education",

- strengthening the dialogue between the parents and the School, for example: "La mallette des parents"

- new measures to prepare general, professional and technological examinations and the high school degree award

- The Avenir/Future path way help the students to build their educational project

\section{Territorial}

45 DGESCO DREDIE, “tous mobilisés contre le décrochage scolaire, Guide mise en oeuvre du parcours aménagés de formation initiale”, novembre 2015. 
- The REP +, Priority Education Network, the main goal is to reduce the effects of social inequality on education, more funding for deprived areas.

- To develop the educational teams' cooperation within establishments and with the extern partners (like in SAS project).

- To value in every academy (regional education authority) the mobilization of all actors against the early school leaving.

- To Support the training in prevention of early school leaving for the teachers.

- Developing concerted actions School/Companies

- Involving every one (parents, civil society, economic field, teachers, national education ministry ...) in a co-education spirit.

- Propose a platform to go back to training.

The three detailed initiatives in France, are:

1. The platform to way back in training, called "Come Back to Training", launched in May 2015, is an information campaign and an individualized guidance for young people who left the school system without qualification. The main objective is to inform them about the rights they have and to advice and help them to take the way back in training. The methodology used is a digital platform/website that proposes information in a playful and visual way and a service of free reminder by counsellors with a prompt care and a personalized follow-up for young people who make the request. This reminder allows to fix in 15 days an appointment with a referent who will follow the young front, hanging and after his return in training. The main results were that 1,226 youngsters "hung up" through the platform "Come back to training". From May to November 2016, 13,407 demands were transferred to a counsellor through the form of reminder of the website and 5,586 resulted in a meeting with a referent, allowing the return in training of 1,226 school leavers. This initiative is available at: http://reviensteformer.gouv.fr/.

2. The MLDS (mission of fight against the early school leaving), defined in 2013, acts to prevent early school leaving and to help youngsters back into education to gain qualifications and support them during their studies. There are three major objectives: to prevent ESL, to facilitate the access to the diploma and to the qualification and to contribute to the reassurance of the routes of training. It's for pupils aged over 16 who have already been out of school for less than a year, without any immediate prospects of study or finding a job. It is also for those who are regularly enrolled and in situation of school break, absentees and wishing to abandon their studies.

The methodology of MLDS includes: 
- To locate the pupils of more than 16 years old showing signs of early school leaving;

- To implement platforms of follow-up and support for décrocheurs and the inter-ministry system of information exchange (SIEI);

- actions preparing a training leading to a qualification, and any other actions of remobilisation.

Main results of MLDS are: the number of young people dropping out of the system of initial training every year decreased from 140,000 in 2010 , to 80,000 in 2017 . The initiative is available at: http://eduscol.education.fr/cid55115/mission-de-lutte-contre-le-decrochage.html.

3. The Service Civique/Civic Service, a project that exists since 2010, has as first ambition to offer to young people the opportunity to make a commitment, to give time to the community and to the others. It also represents the possibility of living a training and developing experience, by proposing a choice among numerous missions, in very diverse domains. It has finally for objective to strengthen the national cohesion and the social mix. In the plan to individualize the school path, (Parcours aménagé de formation initiale) it is possible to propose a civil service to the students in order to motivate them for training with a civic experience that can be valued for the studies.

Regarding the methodology of this initiative, the volunteers receive between $€ 580,55$ and $€ 688,21$ euros a month. It can be done with associations, regional and local authorities or public institutions, over a period from 6 to 12 months in France or abroad, for a mission of at least 24 hours a week. There are 9 big domains in civic service: culture and leisure activities, international development and humanitarian aid, education for all, environment, emergency intervention in a crisis, memory and citizenship, health, solidarity, sport.

Concerning the main results of the Civic Service: in 7 years (from 2010 to 2017), about 280.000 young people have already made a civic service. Young people under the age of 25 years can ask to make a commitment to experience "living together", citizenship, or general interest. It has been widened to the age of 30 for the young people in situation of handicap. The initiative is available at: http://reviensteformer.gouv.fr/.

\section{Italy}

The detailed initiatives reported by the Italian partner are: Fuoriclass, "Work in progress" Villafranca di Verona and Project LAPIS (Laboratori per il Successo). 
The Fuoriclasse - A successful model for the fight against early school leaving was a three-year period project: the pilot project was launched in the 2012/2013 school year in the cities of Naples, Crotone and Scalea (CS); in 2013/2014 Milan and Bari joined; and, finally, in 2014/2015, Turin was added. "Fuoriclasse" accompanies the pupils of the fourth grades of primary school and secondary schools of first grade in areas with a particular social and economic disadvantage for a two-year period and until the transition to the next level of education.

The project promotes the motivation to study and the possibility of filling educational gaps through innovative methodologies and formal and non-formal education activities during school and extra-school hours. It provided an integrated approach that involves: students, teachers, families. Several activities were proposed as methodologies, separated by target groups: only for students, for students and adults and only for adults.

For the students, the activities were: 1) motivational workshops, to enhance skills with peer education activities; 2) school camps, to promote functional dynamics for the development of the class group; 3 ) support to study, fill in training gaps.

For students and adults, the activities foreseen: 1) advisory councils, permanent working tables and spaces for discussion between students and teachers on the subject of dropout.

The activities proposed for adults, were: 1) meetings for teachers, to renew motivation; 2) meetings for parents, to promote active participation in school life.

The project has had impact and results. Fourteen comprehensive Institutes and 68 classes of six Italian cities involved: Bari, Crotone, Milan, Naples, Scalea, and Turin: over 1700 students, about 5,000 teachers and over 800 families. It achieves remarkable results in secondary schools of first grade more than in primary schools where are less elements of risk. In defining the evaluation and monitoring plan, two lines were followed: a "perspective" and a "multimethod" evaluation. Using the counterfactual approach to impact assessment, a control group consisting of students not involved in the project was used alongside the group of students involved in "Fuoriclasse" 46 in the same schools. In two years it has reduced the incidence of arriving late for lessons by 20 per cent compared to what would have happened in the absence of intervention. Also, it has reduced: the incidence of families showing disinterest in the school performance of their

\footnotetext{
46 More information on the project available at: $\underline{\text { https://www.savethechildren.it/cosa- }}$ facciamo/progetti/fuoriclasse )
} 
children (-8\%); the percentage of students who often go late for lessons (11\%); the percentage of chronic latecomers (-8.6\%).

The project "Work in progress" Villafranca (Verona) started in the school year 2016/2017 and is currently refunded. The project is supported by Fondazione San Zeno and conducted by Hermete Società Cooperativa Sociale Onlus, in collaboration with the Villafranca local council. It is aimed at young people in the territory of Villafranca. Through concrete actions such as internships, experiential educational fields and active engagement of responsibility on the part of young people, the project aims to intervene in terms of school dispersion, work, skills, responsible orientation and prevention.

The methodology used to prevent ESL include the following activities:

1. Educational experiential camp, for children at risk of school dropout and deviance, under 16 years. The Campus introduces them into "work environment simulation" activities.

2. Traineeships, aimed at young people between 16 and 25 years old, introduced in working contexts with compatible tasks and economic recognition, supported by an external trainer through individual meetings and interviews "of reasoned autobiography aimed at the emergence of deep skills" and "balance of competencies through activities of autobiographical writing".

The main results were that the campus has received numerous requests for participation. The students have done useful work and contributed to local initiatives promoted by the youth policy office for a city festival: an opportunity for integration with other young people and participation and active citizenship with the support of educators.

At the end of the experience, the participants found increased levels of motivation and commitment which were also reinforced by economic compensation for the work done.

Concerning the evaluation of impact, the project includes ongoing monitoring and evaluation of activities. The educational experiential campus involved 11 young people in 2016 and 11 in 2017, aged between 13 and 15, for a duration of 4 weeks experience for each group.

The Project LAPIS (Laboratori per il Successo) is a regional project to combat early school leaving, conceived as an active tool for recovery, re-motivation, orientation and re-orientation. Launched in Piedmont (provinces of Turin, Alessandria, Cuneo and Vercelli) within the Regional Call for Education / Right and duty. This is an integrated school-training path, divided into laboratories and aimed at students aged between 14 and 16 enrolled in secondary and first-degree secondary 
education. The project is developed in a partnership with a professional training institute and a training agency.

The methodology of LAPIS, between 2008 and 2012, planned to combine hours of traditional education on basic subjects with additional 300 hours (400 in origin) of training at a professional training institution, with the inclusion of children in technical laboratories (mechanics, electronics, catering, sales, etc.). At the end of the school year, the students can obtain the middle school certificate with a qualified exam, but legally recognized (and within the terms established by law). In some cases, direct placement on the second year of the vocational training course can be envisaged. The number of places is limited and is accessed through a selection that considers the number of repetitions and the outcome of an individual interview. In this period, main results are: 30 schools involved, 487 young people included in the LAPIS courses, in 4 school years; 391 LAPIS students eligible for the middle school exam (80.3 per cent of the students involved); 20 $25 \%$ of the number of repeaters included in the LAPIS routes on the total number of $2 \mathrm{nd}$ and $3 \mathrm{rd}$ middle school year multi-repeaters. The website of the project on this period available at: http://www.ciofs.net/Progetti/ Realizzati/Progetto-Lapis.

AFP has activated LAPIS projects (Laboratori per IL Successo) from school year 2008/2009 up to 2016/2017. The laboratories in the city of Cuneo were held in collaboration with the Training Institute for San Carlo Technical Schools and saw the involvement of about 10 Comprehensive Institutes of the territory. The laboratories on the AFP headquarters in Verzuolo also took place starting from school year 2008/2009 up to school year 2016/2017 involved about ten Comprehensive Institutes of the territory of Saluzzo.

\section{Portugal}

In Portugal, the detailed initiatives are the National Program to Promote Success at School and three local initiatives with potential to be replicated: Orquestra Geração/Generation Orchestra; Project InSocialChange and Project 12-15.

The National Program to Promote Success at School is underway. The program is based on the principle that each educational community is the one that best know their contexts, their difficulties and potentialities, and is therefore better prepared to devise strategic plans of action, designed at the level of each school, with the aim of improving student learning. So, the program is designed to fund strategical action plans created by each group of schools. Among other 
initiatives, the program aims at enabling schools to conceive organizational and curricular solutions to improve students' learning and to present them to the Ministry of Education. There have been a number of applications that have exceeded expectations, as mentioned above, and school applied with different methodologies. Information about the initiative is available at: http://pnpse.min-educ.pt/.

The Orquestra Geração project is under way since 2007. It is a project that bets on providing the teaching of music for youngsters and unfavourable communities who had never had contact with the orchestral practice, aiming the social inclusion.

When it started, it aimed to implement the system of the Venezuela's young orchestras: to provide a social support to children and youngsters from 'difficult' neighbourhoods, where the marginality and fragile family units are predominant. It aims the integration of youngsters and children in society through intensive practice of orchestra (a collective work), which increases self-esteem and respect for others, all of it contributing to reach a harmonious development of self-personality, to fight against school absenteeism and to prevent marginality.

The project also broadens its scope of activity to establishing relationships with the families of the children and youngsters, promoting its closeness and progressive integration in the orchestras' activities. This enlarges the responsibility and motivations to the whole family in the results that all the involved are, then, willing to achieve. The methodology is intensive orchestra practice and promotion of close relationships with the families of the pupils. The information about the Orchestra is available at their official website http://www.orquestra.geracao.aml.pt/.

The project InSocial Change started in 2014 and is already finished due to the end of funding. The main objective of the project was to use the knowledge and experience of senior professionals to help young people acquire the skills and capabilities required by the labour market. Designed to promote the employability of young people at risk of social exclusion in the municipality of Amadora, the expectation was that the project would improve the relational and teamwork skills - as well as the self-confidence - of the young participants.

There were several methodologies used in the project: mentoring, coaching and vocational education tools. Public vocational courses currently lack some of the key contents required for competitiveness in the labour market, and this project, implemented in the municipality of Amadora, disseminated an innovative intervention methodology, bringing together mentoring, coaching and vocational education tools, drawing on the experience of those senior 
professionals which were to act as mentors and coachers. More than 60 youngsters have been involved in the project.

The project also addressed the need to update the teachers' skills on the issue of employability and organised seminars for sharing experiences among senior professionals, businessmen, teachers, youth and education stakeholders. According to the Director of the Group of Schools, it was a project with great success. The information about the project is available at: https://gulbenkian.pt/en/initiatives/cidadania-ativa-programme/supported-projects/fieldof-intervention-d-projects/.

Last, project 12-15 is essentially aimed at significantly reducing absenteeism and school failure among young people between the ages of 12 and 15, who have dropped out of school or are at risk of doing so, and preferably not have completed the 1st Cycle of Basic Education. The goal of the project is for these young people to complete the 2nd Cycle of Basic Education and to return to the regular school. However, it is not enough to know that the young have resumed a regular school course, it is also important to make them see the school and its potentialities in a different way.

Therefore, Project 12-15 promotes the "attractive school", that is to say, young people are made aware of the several potentialities of the school space so that they modify not only their attitude towards the school, but also their perspective regarding school agents and learning culture of the school. Thus, after observing the established schedule for the curricular activities, other play activities are provided, mainly in areas capable of motivating and stimulating the interest of these young people. This way, it is expected that the school will be considered as a place where it is good to stay, because it provides the possibility of learning outside and within the context of the classroom.

The return to school, a new image about it, the possession of a higher qualification than the one of departure are meritorious ends, to which are added other gains, such as: social integration, the improvement of the quality of life, reinforcement of self-esteem and motivation, among others. According to the source of the information about the project (https://goo.gl/R6hGXe) at Escola Intercultural/Intercultural School, (https://g0o.gl/R6hGXe) four classes with 60 students were implementing the project. The global success of the students involved at the first period of the $2017 / 2018$ school year is 76 per cent (https://goo.gl/JyaDjW). 


\section{Romania}

Romania reported the initiatives: Access to education for disadvantaged children, Rehabilitation of school infrastructure and Programs for educational integration/reintegration for disadvantaged children.

The Access to education for disadvantaged children is an initiative of the EU, NGOs and the Romanian Government which was developed between 2001 and 2010. The initiative aimed to the reintegration of early school leavers in Summer kindergartens, School mediation and Schools for parents. Main results: a new Second Chance curriculum which includes information in the Roma culture; 584 school mediators (between the school and the Roma community) were trained and then hired at national level; and, in Summer kindergartens, activities with parents and educational materials for the school personnel were developed.

The rehabilitation of the school infrastructure was implemented between 2001 and 2010, in schools of the pre-university system. The objective was to set measures of modernization in order to ensure the safety, hygiene and comfort of pupils. Main results: 610 new buildings, 503 refurbished buildings and 356,500 pupils were beneficiaries of these measures.

The Programs for educational integration/reintegration for disadvantaged children were implemented by Save the Children Romania between 2010 and 2017. They consist of summer kindergartens for Roma children aged 4-7 who never went to kindergarten; Second Chance program for children and youngsters aged 7-18 who were either never enrolled in the school system or dropped out; School after School program for children and youngsters aged 7-18 who are at risk of ESL. The methodologies developed include: supporting in doing homework, learning for exams, learning to write/read; financial support (school supplies, hygiene products, clothes, and food); juridical, psychological counselling and other kind of activities needed, such as support in getting identity papers, enrolling in the medical/school system. Main results: 30,755 children involved, in which 6.905 in summer kindergarten, 3,933 in Second Chance and 19,917 in School after school.

\section{UK}

The UK reported the following initiatives: People \& Communities Strategy; Peterborough's Child Poverty Strategy and Children \& Young People’s Joint Strategic Needs Assessment. 
The People \& Communities Strategy is ongoing in Peterborough. It means: protect the most vulnerable people and communities; maximise the health and wellbeing opportunities for individuals; provide the right level of information and support to individuals so they can make informed choices on the services they need; redesign services with community organisations to be more responsive and better meet the needs of individuals.

The methodologies are:

- Equipping people and communities with the information, tools and capacity to manage demand on public services - Our aim is to enable communities to identify who might need support and where they can go locally to find help, for example through local networks and community organisations who can provide information and services. Through working with community organisations we can identify vulnerable people and ensure that they receive the right services at the right time.

- Developing an effective and robust voluntary, community and faith sector that can support people and communities to manage their needs - we already work with a whole range of organisations such as housing providers, charities and faith groups to deliver services and provide essential support. We want to do more to support the sector by ensuring that local organisations have the skills, capacity and access to funding.

- System leadership is central to our overall vision - the council, the voluntary, community and faith sectors and other partners will take collective responsibility for leading, coordinating and delivering sustainable improvement. If we are to be successful at delivering this strategy, then the council needs to work with other organisations, including the police, health organisations, businesses and the civil sector. This will allow us to improve delivery of services and better support individuals and communities to help themselves.

There are no results yet, but key to Below 10 since this is the current City Council Policy. The Peterborough's Child Poverty Strategy is ongoing until 2020, since 2016. The strategy includes:

- Reducing the reliance on crisis services.

- Developing greater resilience amongst families so they are better equipped to manage challenges 
Key priorities

- Priority 1 Addressing barriers to work, which includes childcare provision, skills, and using the Connecting Families

- programme to break down barriers to work for parents.

- Priority 2 Improving standards of living (food poverty, affordable warmth, health etc.)

- Priority 3 Preventing poor children from becoming poor adults through enhanced skills, education and citizenship

- Priority 4 Reducing family debt and preventing financial crisis by improving financial resilience through improved skills and employment

- Priority 5 Recognising the connection between relationships, income and personal well-being in overcoming disadvantage

- and living well leading to increased resilience.

The methodology is: review a basket of key indicators which focus on work, education and 'other' indicators which relate more broadly to child poverty; review our progress on the key actions to the Health and Wellbeing and Safer Peterborough Partnership Delivery Board on a six-monthly basis.

Regarding the Children \& Young People's Joint Strategic Needs Assessment, it was implemented in 2015 and was multi-agency approach to tackle the needs of children including mental health, care, family, poverty reduction, drug abuse, sexual exploitation and more. The policy highlights the fact that Peterborough is forecast to be the fastest growing LA with the highest number of children in England. 


\section{RESEARCH RESULTS}

\subsection{Key findings on school failure and ESL from the perspective of the youngsters}

As described previously, in this research young people was consulted through the use of qualitative tools, i.e. interviews and focus groups, and asked to identify the complex decisions, actions, attitudes, behaviour and views underlying ESL not only at individual level but also at family, school and community levels. Interviews were conducted and focus groups formed at national level by each participating country. The next sections proceed to the presentation and analysis of the information gathered through that activities and reported by the partner using the template. ${ }^{47}$ Factors explaining disengagement and ESL are shown in several tables.

\subsubsection{Factors leading to failure and ESL}

The factors identified and developed by the youths interviewed by the partners were grouped into four categories: individual, family, school and community (not directly related to individual, family or school, even though affecting them).

We are starting with the individual factors, those which young persons identified as contributing towards the difficulties they themselves or their peers had encountered along their school paths. These factors were under the following dimensions or categories: $a)$ motivation and attitude; $b$ responsibilities and financial constraints; c) autonomy and responsibility; d) health; e) others (Table 4.1).

The individual factors related to motivation and attitude are all that relate to: the lack of motivation for education, disliking school, having difficulties to concentrate and to keep routines, feeling boredom, absenteeism, not being able to make projects in the medium and long term. Some aspects more related to negative behaviour as a whole (towards teachers and specific subjects, indiscipline and oppositional attitudes, bad habits or anger issues) were reported by all partners, except Romania. It is interesting to note this convergence, as all partners reported nearly the same (de)motivation and other attitude factors contributing to explain ESL paths, as they have direct consequences in failure (and are, sometimes, result from that, as indicated in Italy or in Portugal "demotivation due to retentions").

${ }^{47}$ Although factors were identified, no quotes were present by the UK partner. 
Because I had already failed two years and after that, I don't know, I just didn't have the head for school. I didn't want to get up early. It was always being failing. A bad phase and I only wanted to stay at home sleeping because the classes were early and I wasn't going to go for anything. [Isabel, 22, NEET, Portugal]

The issue of responsibilities and financial constraints is another dimension of individual factors found in young participant speeches. On that matter, particularly the need to contribute for the domestic budget or the desire of economic autonomy were indicated by the young participants across the countries. For example,

I didn't want to miss anything in life or spend all that years in school but make my own money. I thought I was smart and old enough to decide for myself. Now I know I wasn't. [Miloš, 22, ESL, Croatia]

Only in Portugal and Italy both the need to help the family and the desire to have finance autonomy were referred.

About autonomy and responsibility (or lack of both), as a factor explaining failure and ESL, it was not indicated, as such, in Croatia, Romania and the UK. It has emerged in the social survey conducted by France, Italy and Portugal, as shown in Table 4.1, the passivity and inability to respond to challenges in an appropriate manner, to work by themselves, to choose a path, or to evaluate job chances.

Table 4.1 Individual factors explaining disengagement and ESL (Youth)

\begin{tabular}{|c|c|c|}
\hline Individual & Individual factors in each country & Quotes from all partners \\
\hline $\begin{array}{l}\text { Motivation and } \\
\text { attitude }\end{array}$ & $\begin{array}{l}\text { HR } \\
\text { - lack of motivation for education } \\
\text { - too often absent from school } \\
\text { - negative attitude towards teachers } \\
\text { - negative attitude towards specific subjects } \\
\text { FR } \\
\text { - boredom, no pleasure at school, no aims } \\
\text { - lack of motivation, studies got no meanings, } \\
\text { useless } \\
\text { - not motivated by the academic content and } \\
\text { academic pedagogy } \\
\text { - not being able to make projects in the medium, } \\
\text { long term } \\
\text { - lost confidence in their capacities, spiral of failure }\end{array}$ & $\begin{array}{l}\text { - I wanted to be a doctor but teachers told me I will } \\
\text { never be what I want because I wasn't a good } \\
\text { pupil. They always discourage me... They } \\
\text { indicated to the administration that I was beaten } \\
\text { by my parents even if it was not true. For these } \\
\text { reasons, I hated going to school [Caroline, 19, } \\
\text { Young people who have returned to school or } \\
\text { training after leaving or suspending, France]. } \\
\text { - I have good results because I'm motivated. I want } \\
\text { to success in life and like to see my parents } \\
\text { proud. Without school, we have more chances to } \\
\text { fail in life" [Benjamin, 17, young people enrolled in } \\
\text { school, France] } \\
\text { - Because I had already failed two years and after } \\
\text { that, I don't know, I just didn't have the head for } \\
\text { school. I didn't want to get up early. It was always } \\
\text { being failing. A bad phase and I only wanted to } \\
\text { stay at home sleeping because the classes were } \\
\text { early and I wasn't going to go for anything. } \\
\text { [Isabel, 22, NEET, Portugal] }\end{array}$ \\
\hline
\end{tabular}




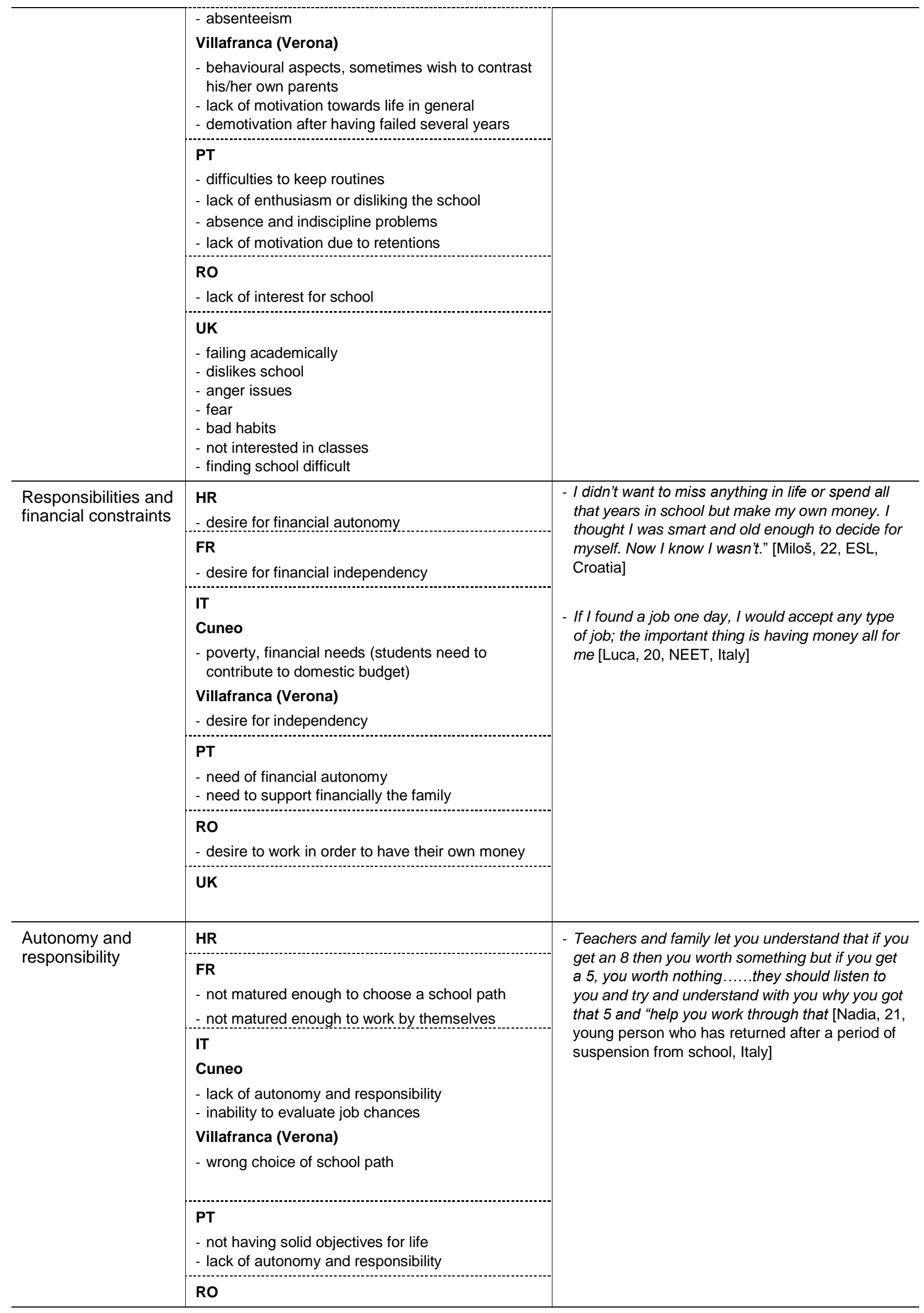




\begin{tabular}{|c|c|c|}
\hline & UK & \\
\hline \multirow[t]{6}{*}{ Health } & $\begin{array}{l}\text { HR } \\
\text { - health problems }\end{array}$ & \\
\hline & $\begin{array}{l}\text { FR } \\
\text { - lack of sleep } \\
\text { - addictions (games, internet, especially social } \\
\text { media) } \\
\text { - psychological problems }\end{array}$ & \\
\hline & $\begin{array}{l}\text { IT } \\
\text { - difficulties of concentration }\end{array}$ & \\
\hline & $\begin{array}{l}\text { PT } \\
\text { - difficulties to concentrate in classes }\end{array}$ & \\
\hline & $\begin{array}{l}\text { RO } \\
\text { - drug use }\end{array}$ & \\
\hline & $\begin{array}{l}\text { UK } \\
\text { - mental health problems } \\
\text { - autism, behaviour issues, other health issue } \\
\text { (anxiety / stress / eating disorders) }\end{array}$ & \\
\hline \multirow[t]{6}{*}{ Others } & $\begin{array}{l}\text { HR } \\
-\end{array}$ & \multirow{6}{*}{$\begin{array}{l}\text { - For me, most of my problems came from the fact } \\
\text { that I did not have an ID. Nobody would hire me } \\
\text { without my documents and I cannot work illegally } \\
\text { my whole life and face check after check. I am } \\
\text { tired of being told, "Hold on, you are under aged, } \\
\text { you don't have legal documents, you can leave". } \\
\text { [Marius, 19, NEET, Romania] }\end{array}$} \\
\hline & $\begin{array}{l}\text { FR } \\
\text { - language (migrants' children) }\end{array}$ & \\
\hline & $\begin{array}{l}\text { IT } \\
\text { Cuneo } \\
\text { - difficulties in establishing relationships with } \\
\quad \text { schoolmates after school retention } \\
\text { Villafranca (Verona) } \\
\text { - pregnancy }\end{array}$ & \\
\hline & $\begin{array}{l}\text { PT } \\
\text { - adolescent pregnancy }\end{array}$ & \\
\hline & $\begin{array}{l}\text { RO } \\
\text { - lack of identity documents } \\
\text { - pregnancy }\end{array}$ & \\
\hline & UK & \\
\hline
\end{tabular}

Young participants also identified health problems underlying ESL. Those may be psychological, addictions (France or Romania), lack of sleep, as indicated in France, or difficulties to concentrate that were identified both in Italy or Portugal. Specific health problems, such as autism and eating (or other) disorders only have been reported by the UK.

Other individual problems not categorized are, for example, adolescent pregnancy (Italy, Portugal and Romania) or different languages (relevant when there is an immigrant background) or problems with identity cards. In Romania, it was reported one of these cases:

For me, most of my problems came from the fact that I did not have an ID. Nobody would hire me without my documents and I cannot work illegally my whole life and face check after check. I am tired of being told, "Hold on, you are under aged, you don't have legal documents, you can leave". [Marius, 19, NEET, Romania] 
Family factors (see table4.2) bring together how the prevailing social conditions of these youths impact on their academic path, especially problems related with lack of economic resources in their households, but also family structure, family relationships and family engagement with education and school.

The list of a large number of aspects in which resources hold particular relevance (economic difficulties and problems, low levels of parents' skills and education, unemployment, poorly qualified and badly paid jobs, work overload with two or multiple jobs) is common in all countries, so there is a strong pattern identified in here.

Alongside the family structure, such as belonging to extended or single parent families, the accumulation of many household duties, such as caring for younger siblings and undertaking domestic tasks. Overcrowded households as stressed in Croatia and Portugal, combined with the mentioned caregiver duties, difficult privacy and conditions to study.

\section{I have to do homework when everyone sleeps at home because I have to clean up things, to cook and take care of my brother before having time to learn [Sophie, 17, Young people who have returned to school or training after leaving or suspending, France].}

Only in Italy and in UK there were no factors we could associate with family structure.

All young participants in the social survey indicate several problems related to family relationships. We could find examples from abuses (as psychic, physical, and alcohol, as in Croatia, or parental relationship based in punishments), to broken families due to divorces or other kind of problems and conflicts (as in France, Italy and Portugal).

I left school for many reasons but it was mainly due to my family's troubles. My parents [Mehdi, 23, Employed young people who have not completed upper secondary education or vocational training, France] 
Table 4.2 Family factors explaining disengagement and ESL (Youth)

\begin{tabular}{|c|c|c|}
\hline Family factors & Family factors in each country & Quotes from all partners \\
\hline \multirow[t]{6}{*}{ Resources } & $\begin{array}{l}\text { HR } \\
\text { - low and very poor socio-economy status of family } \\
\text { - work and money problems } \\
\text { - high unemployment rate } \\
\text { - low level of education in family } \\
\text { - lack of parents' competences }\end{array}$ & \multirow[t]{6}{*}{$\begin{array}{l}\text { I want to learn because I want to make sure that } \\
\text { when I am in the city, I can read the name of the } \\
\text { bus stop and know where I am; when I go to a } \\
\text { store, I want to make sure that the cashier is } \\
\text { giving me the right change. [Ovidiu, 16, young } \\
\text { person at high risk of early school leaving, } \\
\text { Romania] }\end{array}$} \\
\hline & $\begin{array}{l}\text { FR } \\
\text { - financial difficulties, poverty } \\
\text { - unemployment } \\
\text { - excess of working hours } \\
\text { - work overload (multiple jobs) } \\
\text { - work overload (two jobs) }\end{array}$ & \\
\hline & $\begin{array}{l}\text { IT } \\
\text { Cuneo } \\
\text { - low skilled parents } \\
\text { - low-skilled and low-paid jobs } \\
\text { Villafranca (Verona) } \\
\text {-need of additional family incomes from son's job }\end{array}$ & \\
\hline & $\begin{array}{l}\text { PT } \\
\text { - economic difficulties } \\
\text { - low skilled parents } \\
\text { - unemployment of the parents (current or former) } \\
\text { - low skilled and low paid jobs }\end{array}$ & \\
\hline & $\begin{array}{l}\text { RO } \\
\text { - lack of financial resources }\end{array}$ & \\
\hline & $\begin{array}{l}\text { UK } \\
\text { - parents have no or few qualifications } \\
\text { - parents unemployed } \\
\text { - parents requiring students to work to generate } \\
\text { money }\end{array}$ & \\
\hline \multirow[t]{6}{*}{ Family structure } & $\begin{array}{l}\text { HR } \\
\text { - overcrowded living conditions }\end{array}$ & \multirow{6}{*}{$\begin{array}{l}\text { I have to do homework when everyone sleeps at } \\
\text { home because I have to clean up things, to cook } \\
\text { and take care of my brother before having time to } \\
\text { learn [Sophie, } 17 \text {, Young people who have returned } \\
\text { to school or training after leaving or suspending, } \\
\text { France]. } \\
\text { When we leave the school it is often because there } \\
\text { are problems at the house, the child cannot } \\
\text { concentrate. It is the first cause, after there is an } \\
\text { overwork of the school and finally there is a street. } \\
\text { am the only one to have dropped out at my home. } \\
\text { Everybody has diplomas. I was } 17 \text { the years and } \\
\text { half [Laura, 19, NEET, France] }\end{array}$} \\
\hline & $\begin{array}{l}\text { FR } \\
\text { - no family network }\end{array}$ & \\
\hline & IT & \\
\hline & $\begin{array}{l}\text { PT } \\
\text { - overcrowded households } \\
\text { - single parents' families } \\
\text { - youngsters having great responsibilities, like } \\
\text { taking care of younger brothers and to ensure } \\
\text { tasks at home are carried on }\end{array}$ & \\
\hline & $\begin{array}{l}\text { RO } \\
\text { - taking care of younger siblings }\end{array}$ & \\
\hline & $\begin{array}{l}\text { UK } \\
\text { - sibling care responsibilities }\end{array}$ & \\
\hline Family relationships & $\begin{array}{l}\text { HR } \\
\text { - physical and psychic abuse } \\
\text { - alcohol abuse }\end{array}$ & $\begin{array}{l}\text { I left school for many reasons but it was mainly due } \\
\text { to my family's troubles. My parents [Mehdi, } 23 \\
\text { Employed young people who have not completed }\end{array}$ \\
\hline
\end{tabular}




\begin{tabular}{|c|c|c|}
\hline & - lack of parent's border setting mechanisms & \multirow{6}{*}{$\begin{array}{l}\text { upper secondary education or vocational training, } \\
\text { France] }\end{array}$} \\
\hline & $\begin{array}{l}\text { FR } \\
\text { - family problems (separation, violence, divorce, } \\
\text { constant fighting, loss of a loved one, health } \\
\text { problems) }\end{array}$ & \\
\hline & $\begin{array}{l}\text { IT } \\
\text { Cuneo } \\
\text { - family crisis: conflicts, divorces etc. } \\
\text { - conflicts between family members } \\
\text { - absenteeism in youngster's life (i.e. parents' } \\
\text { absence in daily responsibilities etc.) } \\
\text { Villafranca (Verona) } \\
\text { - parents absent and / or distant to their childrens' } \\
\text { school life } \\
\text { - Parents too "hard" (for them, a school failure is a } \\
\text { shame) and/or too "pressing" } \\
\text { - Lack of stimulation to study in order to improve } \\
\text { his/her employability } \\
\text { - families not able to support children in their } \\
\text { moments of crisis If you don't want to study any } \\
\text { more, you must go to work; if you decide to go on } \\
\text { in the school path, you must finish) }\end{array}$ & \\
\hline & $\begin{array}{l}\text { PT } \\
\text { - emotional instability } \\
\text { - parental relationship based in punishments (to } \\
\text { yell or to spank) } \\
\text { - absent parents or parents who are divorced }\end{array}$ & \\
\hline & $\begin{array}{l}\text { RO } \\
\text { - parents' negligence }\end{array}$ & \\
\hline & UK & \\
\hline \multirow[t]{4}{*}{$\begin{array}{l}\text { Family engagement } \\
\text { with education and } \\
\text { school }\end{array}$} & $\begin{array}{l}\text { HR } \\
\text { - inadequate parenting styles } \\
\text { - low family expectations }\end{array}$ & \multirow{4}{*}{$\begin{array}{l}\text { - I know many families in which when the kids get } \\
\text { home from school, they have jobs to do, and they } \\
\text { do not encourage the kids to do their school } \\
\text { homework. (...) After, the following day, they } \\
\text { arrive with double or triple the homework. They } \\
\text { do not do it again. They get punished at school } \\
\text { and the parents are not motivating them. They get } \\
\text { called in to school, they do not go, they skip the } \\
\text { meetings. [Mário, 17, risk of ESL, Portugal] } \\
\text { - This is something that happens in the houses of } \\
\text { many people, I do not talk about domestic } \\
\text { violence, but about parenting discussions, and it } \\
\text { all harms the child's development in school. I } \\
\text { suffered a lot from that and then I had another } \\
\text { way of thinking about school. I regret it, of course, } \\
\text { but I think that at home you have to help the } \\
\text { children in studies. Parents to sit down and help } \\
\text { their children do the work, ask questions, } \\
\text { everything else. To ask how was the school day, } \\
\text { if everything went well, if there were no problems. } \\
\text { You see, it was something I did not have and I } \\
\text { want to give it to my son. [lsabel, 22, NEET, } \\
\text { Portugal] }\end{array}$} \\
\hline & $\begin{array}{l}\text { FR } \\
\text { - lack of family and adult support } \\
\text { - misunderstanding of the school expectations } \\
\text { - misunderstanding of the school codes } \\
\text { - misunderstanding of school mission } \\
\text { - parents who present homework as a punishment } \\
\text { - parents who denigrate school, teachers... } \\
\text { - parents who had problems at school themselves } \\
\text { - parents who devalue school }\end{array}$ & \\
\hline & $\begin{array}{l}\text { IT } \\
\text { - weak parenting and education styles (i.e. parents } \\
\text { replace youngsters in high school choices etc.) } \\
\text { - lack of discipline } \\
\text { - parents with low focus on education } \\
\text { - lack of stimulation to study } \\
\text { - parents with difficulties in supporting school tasks } \\
\text { - considering attending school as a waste of money } \\
\text { - depreciation of school certificates and not seeing } \\
\text { reason for school } \\
\text { - lack of reward or encouragement in case of } \\
\text { children's school results } \\
\text { - experience of failure and ESL of siblings } \\
\text { - absenteeism in youngster's life (i.e. parents' } \\
\text { absence in daily responsibilities etc) }\end{array}$ & \\
\hline & PT & \\
\hline
\end{tabular}




\begin{tabular}{|c|c|c|}
\hline & $\begin{array}{l}\text { - parents are not focused in education } \\
\text { - parents do not have many expectations related to } \\
\text { the school of their children or the expectations } \\
\text { they have are not adjusted to school reality } \\
\text { - negative experiences among siblings (retentions } \\
\text { and conflicts) }\end{array}$ & \multirow{3}{*}{$\begin{array}{l}\text { [Nicolas, 18, Young people enrolled in education } \\
\text { or vocational training, France] } \\
\text { - My parents didn't agree on my resuming school } \\
\text { because they told me that "I wasted" money } \\
\text { [Laura, 19, young person who has been held } \\
\text { back and is at risk of early school leaving, Italy] } \\
\text { - If you don't feel your parents supporting you, just } \\
\text { a quarrel with classmate to trigger the spark and } \\
\text { give up everything [Chiara, } 22 \text { years old, young } \\
\text { person who have returned to school or training } \\
\text { after ESL or suspending, Villafranca (Verona), } \\
\text { Italy] }\end{array}$} \\
\hline & $\begin{array}{l}\text { RO } \\
\text { - parents' lack of interest towards school }\end{array}$ & \\
\hline & $\begin{array}{l}\text { UK } \\
\text { - family not seeing reason for school } \\
\text { - low aspiration } \\
\text { - parent-teacher liaison does not always prevent } \\
\text { ESL }\end{array}$ & \\
\hline \multirow[t]{6}{*}{ Other } & HR & \\
\hline & $\begin{array}{l}\text { FR } \\
\text { - migration background }\end{array}$ & \\
\hline & $\begin{array}{l}\text { IT } \\
\text { - examples of ESL relatives that have satisfying } \\
\text { jobs (negative examples) }\end{array}$ & \\
\hline & $\begin{array}{l}\text { PT } \\
\text { - health problems in the family }\end{array}$ & \\
\hline & $\begin{array}{l}\text { RO } \\
\text { - economic exploitation by the parents (youngsters } \\
\text { are forced to work) }\end{array}$ & \\
\hline & $\begin{array}{l}\text { UK } \\
\text { - bereavement } \\
\text { - family illness } \\
\text { - missing extended family members in new country, } \\
\text { not living at home with family }\end{array}$ & \\
\hline
\end{tabular}

Concerning family engagement with education and school, a pattern can be traced related to the existence of parental models poorly focused on education (inability to supervise school work, low level or poorly aligned expectations, negative experiences, lack of family and adult support/supervision, etc.), as some dimension of thus devaluation of school was indicated by young participants in every country partner of the project.

My parents didn't agree on my resuming school because they told me that "I wasted" money [Laura, 19, young person who has been held back and is at risk of early school leaving, Italy]

"This is something that happens in the houses of many people, I do not talk about domestic violence, but about parenting discussions, and it all harms the child's development in school. I suffered a lot from that and then I had another way of thinking about school. I regret it, of course, but I think that at home you have to help the children in studies. Parents to sit down and help their children do the work, ask questions, everything else. To ask how was the school day, if everything went well, if there were no problems. You see, it was something I did not have and I want to give it to my son. [Isabel, 22, NEET, Portugal] 
Other kind of family factors mentioned by participants as underlying causes of failure and ESL were migration background (both in France and the UK), health problems of the family (PT and the UK) and negative examples of relatives who are ESL and could get satisfying jobs (Italy). A particular situation needs to be highlighted: in Romania is referred the exploitation of youngsters by parents who force them to work.

About the school factors, in the youth perspective they are especially responsible for causing failure and ESL (see Table 4.3) and the list of these aspects is larger than others in all countries. These are the factors that most negatively influence the academic results, and are above all related with the following school dimensions: pedagogical, relational, organisational and vocational.

From the pedagogical point of view, letting alone more specific relational aspects that also affect pedagogy, one of the key questions emerges from the excessive load of theory comparing with practice at school- this was referred across countries -, or poor or traditional teaching styles, like in France, Italy, Portugal and UK.

There are teachers who are not interesting, who make us sleep. For example, the course of drawing, we do not see the interest with our sector [Martin, 16, young person at high risk of early school leaving, France]

I think the Romanian school system is totally absurd from many points of view. Some teachers are not well prepared, not able to answer our questions and especially in high school, when you feel if a teacher is unprepared. The curriculum is heavy and exhausting, I will certainly not use many of the things I had to learn. Everything is very theoretical and not at all practical, very competitive. The relationship between teacher and pupil could also be improved. Overall, the teaching system should be renewed, more interactive and adapted to the new technology'. [Ioana, 19, young person enrolled in education or vocational training, Romania]

In the relational dimension of the school factors, all young participants in the social survey, in all countries but in Croatia, describe how teachers do not motivate, are not fair, do not treat students equally, are not patient, among other aspects underlying the relationships between students and teachers, or between parents and teachers. The participants also say they have bad relationships with school staff (Italy and Portugal), school mates (Italy) or are, even, discriminated (Romania).

I left school for many reasons... I needed help but there was no one. I tried to continue but it was too hard. Teachers humiliate me several times and others pupils did the same. I had to see a psychologist when I grew up because of these problems. Now, I feel better but there's still something missing me, something I lost in that time I was in school. [Sandra, 30, Employed Early School Leaver, France]

He said that my presence bothered him. [...] I was upset by the guy. You need to know how to deal with every type of student. Not all students are the same. [...] They should pay more attention and 
understand that there are various types of student and have different methods and knowledge appropriate for each one. [Susana, 17, risk of ESL, Portugal]

In the vocational dimension of the school factors, it seems only a key question for France, Italy and Portugal. Problems stem, for example, from lack of support during critical phases of the school path, to choose a curriculum / lack of career guidance (in the cases of France and Italy), having chosen the wrong course by not being prepared, not wanting it or because there are no offers in what was the desired course (as in Portugal).

When we are 13 we are too young to choose our high secondary school and decide what to do. We are a little aware of what we want to become, we have many ambitions; we live continuous changes as teenagers, you find yourself no longer knowing where to go banging your head... [Roberto, 19, years old, young person who have returned to school or training after ESL or suspending, Villaranca (Verona), Italy]

Table 4.3 School factors explaining disengagement and ESL (Youth)

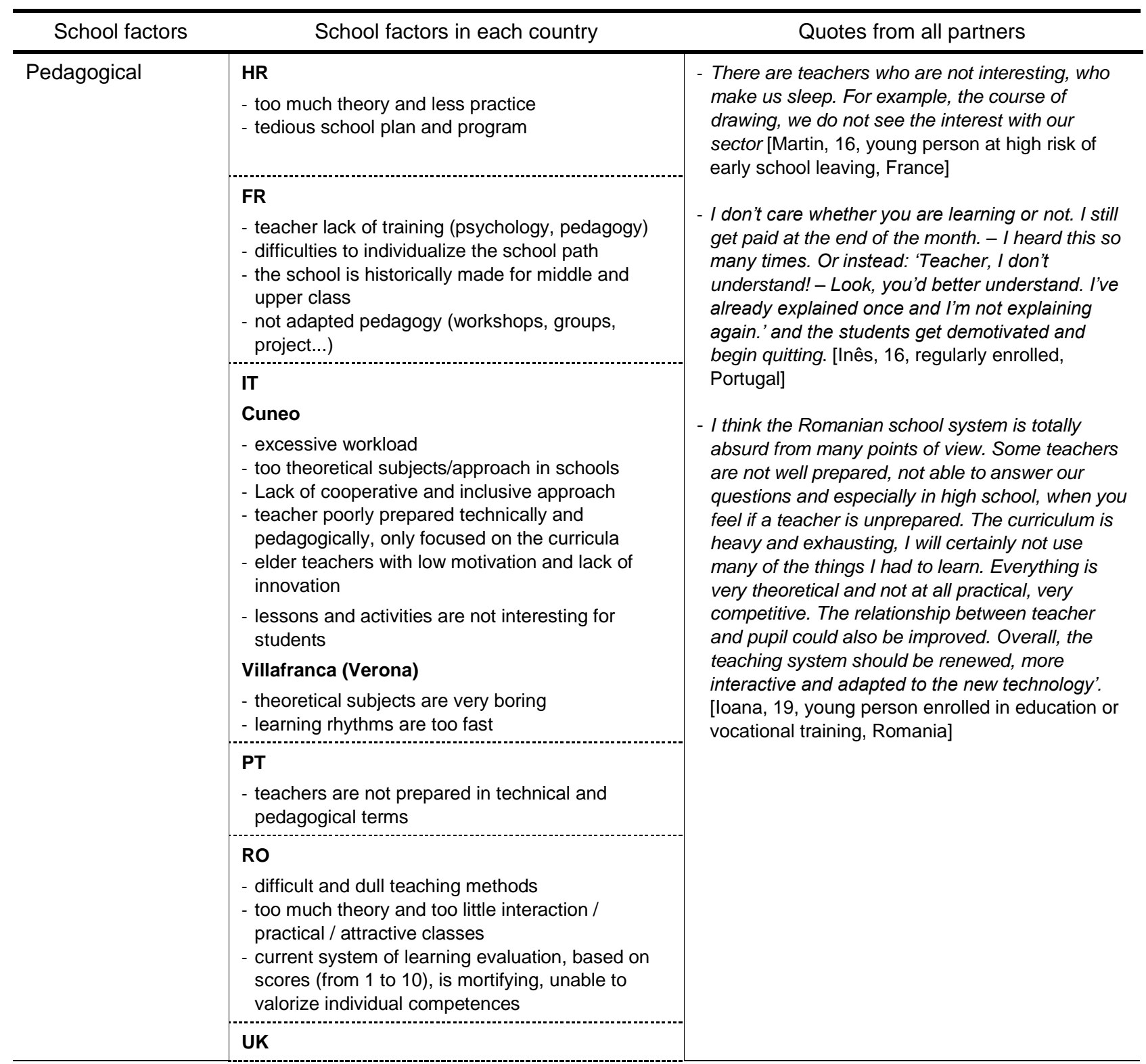




\begin{tabular}{|c|c|c|}
\hline & $\begin{array}{l}\text { - poor teaching styles } \\
\text { - too many exams and poor performance related to } \\
\text { this }\end{array}$ & \\
\hline \multirow[t]{7}{*}{ Relational } & HR & \multirow{7}{*}{$\begin{array}{l}\text { - Teachers have their favourite pupils. So, } \\
\text { whatever I do, they always look at me differently. } \\
\text { think, we should have more good teachers. Those } \\
\text { who care about us and are motivated to give us } \\
\text { knowledge. [Alpha, } 19 \text { years old, young person at } \\
\text { high risk of early school leaving, France] } \\
\text { - Teachers have to be role models instead of } \\
\text { yelling at us or discouraging us. I like the } \\
\text { mathematics teacher who helps us even after her } \\
\text { course. She always takes time to listen and } \\
\text { communicate with us, with our family. She gives a } \\
\text { moral support [Benjamin, 17, Young people } \\
\text { enrolled in education or vocational training, } \\
\text { France] } \\
\text { - I left school for many reasons... I needed help but } \\
\text { there was no one. I tried to continue but it was too } \\
\text { hard. Teachers humiliate me several times and } \\
\text { others pupils did the same. I had to see a } \\
\text { psychologist when I grew up because of these } \\
\text { problems. Now, I feel better but there's still } \\
\text { something missing me, something I lost in that } \\
\text { time I was in school. [Sandra, 30, Employed Early } \\
\text { School Leaver, France] } \\
\text { - I wanted to leave school many times but I didn't } \\
\text { because the head teacher helps me a lot. He } \\
\text { used to ask me questions about my feelings, my } \\
\text { hobbies and other stuffs outside school. Then he } \\
\text { listens to me every time I need to talk. That's } \\
\text { what teachers should do [Adama, 17, Youngsters } \\
\text { with high risk of ESL, France] } \\
\text { - He said that my presence bothered him. [...] I } \\
\text { was upset by the guy. You need to know how to } \\
\text { deal with every type of student. Not all students } \\
\text { are the same. [...] They should pay more } \\
\text { attention and understand that there are various } \\
\text { types of student and have different methods and } \\
\text { knowledge appropriate for each one. [Susana, } 17 \\
\text { risk of ESL], Portugal }\end{array}$} \\
\hline & $\begin{array}{l}\text { FR } \\
\text { - a lot of expectations among the relationship with } \\
\text { teachers } \\
\text { - absence of listening, communication breakdown } \\
\text { - not adapted communication for all the parents on } \\
\text { the school expectations } \\
\text { - negative communication, only when there is a } \\
\text { problem } \\
\text { - no special support for family with difficulties } \\
\text { - humiliating and belittling students } \\
\text { - they don't know the students, their difficulties }\end{array}$ & \\
\hline & $\begin{array}{l}\text { IT } \\
\text { Cuneo }\end{array}$ & \\
\hline & $\begin{array}{l}\text { - lack of teacher motivation, patience } \\
\text { - lack of trust in teachers } \\
\text { - bad relationship within school staff } \\
\text { - bad relationship with schoolmates and teachers } \\
\text { Villafranca (Verona) } \\
\text { - too many teachers are cold, little "human" } \\
\text { - teachers are not able to support students when } \\
\text { they are living a phase of crisis in the relation with } \\
\text { their parents } \\
\text { - Bad relations with schoolmates }\end{array}$ & \\
\hline & $\begin{array}{l}\text { PT } \\
\text { - teachers are not very interested in students } \\
\text { - teachers do not motivate } \\
\text { - teachers are not fair } \\
\text { - teachers treat students unequally } \\
\text { - teachers lack sensitivity regarding students' } \\
\text { needs } \\
\text { - teachers are not patient } \\
\text { - not getting along with school staff }\end{array}$ & \\
\hline & $\begin{array}{l}\text { RO } \\
\text { - discrimination and isolation at school caused by } \\
\text { mates and teachers } \\
\text { - harsh teachers }\end{array}$ & \\
\hline & $\begin{array}{l}\text { UK } \\
\text { - poor relations with teachers } \\
\text { - overuse of 'isolation' punishment } \\
\text { - teacher not seeing issues such a violence in } \\
\text { family }\end{array}$ & \\
\hline \multirow[t]{4}{*}{ Vocational } & HR & \multirow{4}{*}{$\begin{array}{l}\text { - No one asks us what we want to do at the right } \\
\text { time. When we are at primary school, parents } \\
\text { decide for us and one day in secondary school, } \\
\text { without any preparation, they ask us "what do you } \\
\text { want to do?" In addition, sometimes, when we say } \\
\text { what we want, they discourage by saying "it's not } \\
\text { a job to be a singer, dancer, artist, for example. } \\
\text { [Mehdi, 19, Young people at high risk of early } \\
\text { school leaving, France] } \\
\\
\text { - I felt something inside me that indicated me to } \\
\text { study psychology, but teachers suggested me an } \\
\text { upper technical school only because I like playing } \\
\text { videogames. I followed their advice, but it was } \\
\text { completely different from my expectations. I was } \\
\text { rejected [Denis, } 21 \text { years old, young person who }\end{array}$} \\
\hline & $\begin{array}{l}\text { FR } \\
\text { - lack of support during the critical phases of the } \\
\text { school path, to choose a curriculum }\end{array}$ & \\
\hline & $\begin{array}{l}\text { IT } \\
\text { Cuneo }\end{array}$ & \\
\hline & $\begin{array}{l}\text { - lack of career guidance } \\
\text { - ineffective career guidance } \\
\text { - attitude to students' inclinations, interests and } \\
\text { ambitions } \\
\text { Villafranca (Verona) } \\
\text { - wrong choice of the school track }\end{array}$ & \\
\hline
\end{tabular}




\begin{tabular}{|c|c|c|}
\hline & $\begin{array}{l}\text { - rigidity of school system: if you fail in many } \\
\text { subjects, you must repeat the whole school year }\end{array}$ & \multirow{4}{*}{$\begin{array}{l}\text { have returned to school or training after ESL or } \\
\text { suspending, Villafranca (Verona), Italy] } \\
\text { - When we are } 13 \text { we are too young to choose our } \\
\text { high secondary school and decide what to do. We } \\
\text { are a little aware of what we want to become, we } \\
\text { have many ambitions; we live continuous } \\
\text { changes as teenagers, you find yourself no longer } \\
\text { knowing where to go banging your head... } \\
\text { [Roberto, 19, years old, young person who have } \\
\text { returned to school or training after ESL or } \\
\text { suspending, Villafranca (Verona), Italy] }\end{array}$} \\
\hline & $\begin{array}{l}\text { PT } \\
\text { - not liking the course } \\
\text { - choosing the wrong course (not being prepared or } \\
\text { not wanting it) } \\
\text { - no vacancy in the desired course } \\
\text { - lack of offers } \\
\text { - problems with the employability of the vocational } \\
\text { courses and with completion of the internships } \\
\text { - some subjects are considered not needed or } \\
\text { adequate for the courses }\end{array}$ & \\
\hline & ( & \\
\hline & UK & \\
\hline \multirow[t]{6}{*}{ Organizational } & $\begin{array}{l}\text { HR } \\
\text { - bullying } \\
\text { - traditional school system } \\
\text { - sense of lack of school attendance } \\
\text { - old teaching staff }\end{array}$ & \multirow{5}{*}{$\begin{array}{l}\text { There is too much pressure on us and on teachers. } \\
\text { Some of them just want to finish the school } \\
\text { curricula. We should do more cultural and sportive } \\
\text { activities [Ali, } 16 \text { Young people at high risk of early } \\
\text { school leaving, France] } \\
\text { I didn't choose to leave school. They just sent me } \\
\text { home. I would like to continue but I have no support } \\
\text { at school just because I had some difficulties and } \\
\text { bad behaviour (Luis, 20, Young people who have } \\
\text { returned to school or training after leaving or } \\
\text { suspending, France). } \\
\text { Putting together all those who cause a nuisance in } \\
\text { the same class is not good. Even if there are } \\
\text { people who want to study, they end up influenced. } \\
\text { [Bruno, 17, risk of ESL, Portugal] }\end{array}$} \\
\hline & $\begin{array}{l}\text { FR } \\
\text { - a closed up system, no collaboration } \\
\text { - bad image of the parents, social relegation } \\
\text { - lack of communication in the staff } \\
\text { - roles confusion, at the critical moments for the } \\
\text { youngsters they do not know who has to } \\
\text { intervene... } \\
\text { - difficulties to individualize the school path } \\
\text { - difficulties to do prevention } \\
\text { - violence, bad atmosphere in the school }\end{array}$ & \\
\hline & $\begin{array}{l}\text { IT } \\
\text { Cuneo } \\
\text { - accumulation of disciplinary sanctions } \\
\text { - excessive rigidity of rules } \\
\text { - bullying } \\
\text { - students at risk of ESL have a negative influence } \\
\text { on others } \\
\text { Villafranca (Verona) } \\
\text { - lack of financial resources for education }\end{array}$ & \\
\hline & $\begin{array}{l}\text { PT } \\
\text { - to be enrolled in classes that are noisy or } \\
\text { "always" in problematic classes } \\
\text { - excessive academic load in vocational courses } \\
\text { - too short breaks at school } \\
\text { - unsuitable timetables } \\
\text { - rules are too strict } \\
\text { - school delays in informing parents about students } \\
\text { missing classes (lack of communication with } \\
\text { families) } \\
\text { - bullying } \\
\text { - insecurity feeling } \\
\text { - lack of extracurricular activities }\end{array}$ & \\
\hline & RO & \\
\hline & $\begin{array}{l}\text { UK } \\
\text { - bullying } \\
\text { - class size too large } \\
\text { - school rules on uniform } \\
\text { - experience of racism }\end{array}$ & \\
\hline
\end{tabular}


Last in school factors are organizational features. Bullying is one of those factors described by young participants in all countries but France and Romania, even though in France they also indicate violence and bad atmosphere at school. They also include relationships with families and factors as rigidity of rules, the traditional characteristic of the school system, old teaching staff, lack of communication in the staff, classes too large, frequent enrolment in problematic or noisy classes and lack of extracurricular activities, compete to explain why school have an inflexible kind of organization and contributes, in young participants' point of view of the different countries, to failure and ESL.

There is too much pressure on us and on teachers. Some of them just want to finish the school curricula. We should do more cultural and sportive activities [Ali, 16 Young people at high risk of early school leaving, France]

I didn't choose to leave school. They just sent me home. I would like to continue but I have no support at school just because I had some difficulties and bad behaviour [Luis, 20, Young people who have returned to school or training after leaving or suspending, France].

I always had the bad luck of getting placed in the worst classes. Basically, this was where there were the bullies, at the time, and that influenced everybody. This also ended up influencing me. (...) There was one still worse class. There was another that was all calm. [João, 18, employed ESL, Portugal]

Community factors (see Table 4.4) are the ones describing the aspects not directly related to family, school or the individual, but that impact on ESL. Described by participants in the social surveys of all partners were peer pressure, dropout of friends or bad influences. But these community factors also include violence and problems of the neighbourhoods, such as economic deprivation, feelings of being unsafe in the territory, drug traffic and delinquency - not in the cases of Italy and Romania. Of great importance, also, are the role models: in Portugal, on one hand, the reference of the inexistence of good examples of people with longer school trajectories; on the other hand, in France the reference to role models associated with sports, business, "stars", and other people with careers not requiring studies.

The community factors also are related with the labour market. Both in Italy and Portugal, the question is the pressure and labour market competition in order to be completely integrated during or soon after internships and before the course's completion. In the UK, we highlight a singularity not mentioned by young participants from other partners' countries: the existence of local employers who explore young people for cheap jobs not requiring qualifications. 
Table 4.4 Community factors explaining disengagement and ESL (Youth)

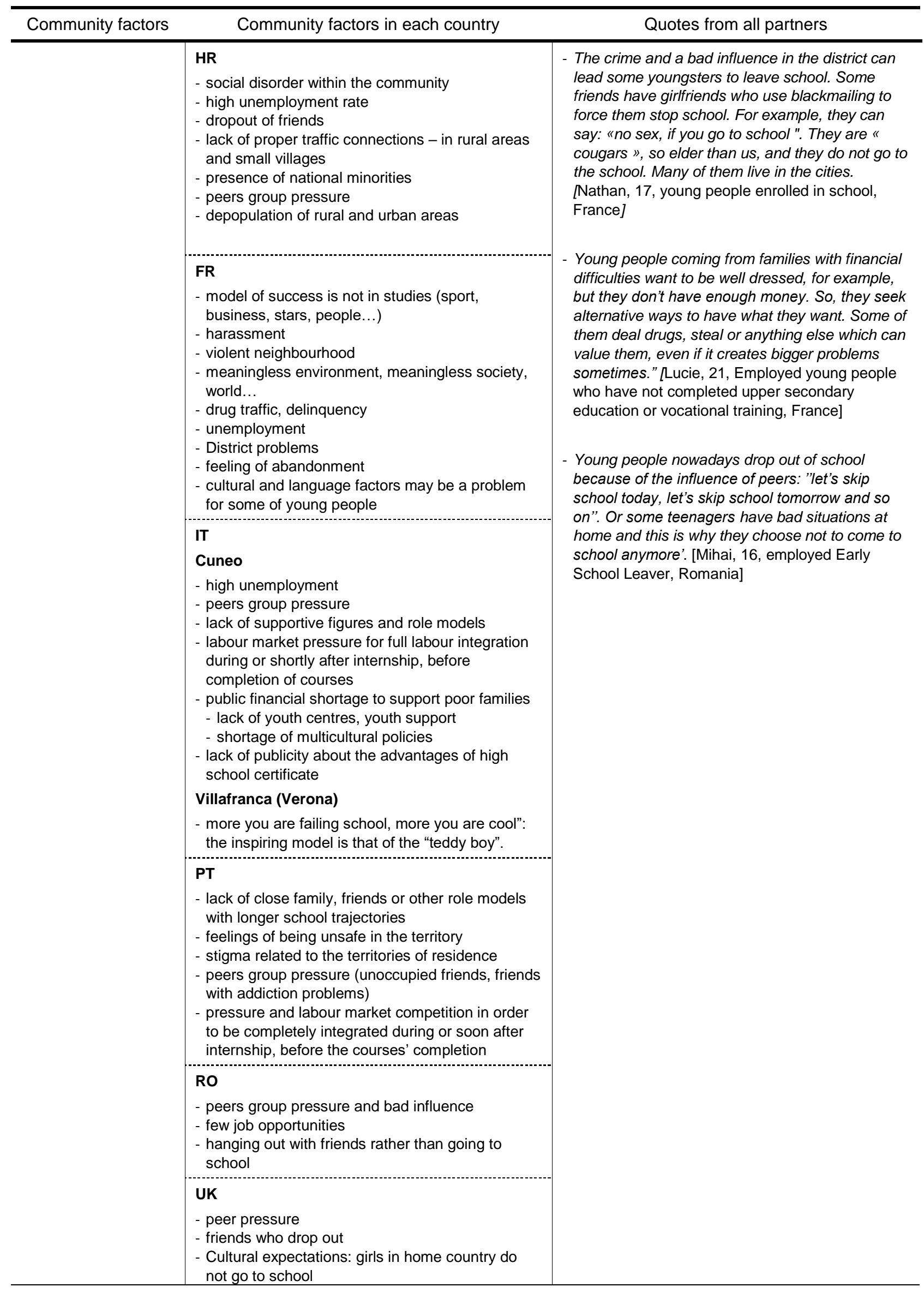




\subsubsection{Life histories}

As part of the investigation on the decisions, actions, attitudes, behaviour and views underlying ESL, a substantial number of young people "typical histories" that reflect the different situations in which ESL occurs were gathered. ${ }^{48}$

They are presented as "life histories", accounts based on the 38 in-depth interviews made by six partners, aiming to highlight the diversity and complexity of the young people experiences and give voice to individuals. ${ }^{49}$

They have the ability to link micro and macro processes, capture processes of change and help to identify the structures and agency that produce choices in a particular individual's life. The term "life history" (also called personal narrative, biography, life story...) refers to a collection and interpretation of personal stories gathered during an interview, for the purpose of understanding "the changing experiences and outlooks of individuals in their daily lives, what they see as important, and how to provide interpretations of the accounts they give of their past, present and future". 50

This chapter proceeds to the analysis of the main trends that emerge in the life experiences of 5 profiles of youngsters:

a) Early school leaver not in employment, education or training (NEET)

b) Employed Early School Leavers

c) Young person at high risk of early school leaving

d) Young people who have returned to school or training after ESL or suspending

e) Young people enrolled in education or vocational training

\footnotetext{
48 No life history is presented for UK, since it was not collected by the team.

${ }^{49}$ We are not considering 13 interviews conducted in the UK since no life history was presented.

50 See Roberts, B. (2002). Biographical Research. Open University Press, Buckingham and Philadelphia. p. 1. We use the term life history, an account of someone's life given by the researcher, distinguishing it from the "life story" recounted by the person itself.
} 
Each of these profiles is illustrated with a set of life histories. In these, a biographical synthesis is carried out, identifying the key social and school contexts and dimensions that shape the paths, the educational experiences, and the individual aspirations.

These 29 histories describe the experiences of 14 boys and 15 girls, aged between 13 and 27 years old. The 17-19 year olds is the largest group (twelve life histories), and the 13-16 year olds group has proportionally more boys. In all life stories, the names were anonymised to protect the identity of the youngsters.

Table 4.5 Characterization of participants in life stories, by sex, age, country and profile

\begin{tabular}{|c|c|c|}
\hline Sex & $\mathrm{N}$ & $\mathrm{N}$ \\
\hline Male & 14 & \\
\hline Female & 15 & \\
\hline Total & 29 & \\
\hline Age groups & FM & $\mathrm{F}$ \\
\hline $13-16$ & 7 & 3 \\
\hline $17-19$ & 12 & 6 \\
\hline $20-27$ & 10 & 6 \\
\hline Total & 29 & 15 \\
\hline Country & FM & $\mathrm{F}$ \\
\hline Croatia & 5 & 4 \\
\hline France & 6 & 3 \\
\hline Italy & 8 & 4 \\
\hline Portugal & 5 & 3 \\
\hline Romania & 5 & 1 \\
\hline Total & 29 & 15 \\
\hline Profile & FM & M \\
\hline Early school leaver (NEET) & 5 & 3 \\
\hline Employed Early School Leavers & 6 & 2 \\
\hline Young person at high risk & 4 & 3 \\
\hline Young people who have returned to education & 9 & 5 \\
\hline Young people enrolled & 5 & 2 \\
\hline Total & 29 & 15 \\
\hline
\end{tabular}

Initially it was foreseen that each country would collect a life history for each young people profile ( 5 in total, 10 for Italy which has two territories). However, the material sent by the 
partners did not necessarily correspond to this distribution. We privileged the inclusion of all collected cases. ${ }^{51}$

The 29 life histories made it possible to observe a set of conditions and dimensions that directly or indirectly influence the structuring of personal and school paths of the young people. The organization of collected information, reflective and descriptive, points to similarities and dissimilarities, singularities and regularities. It also places the reader in a privileged, especially rich, position of observation and interpretation, in relation to other genres of analysis and presentation available. Not wishing to compromise this perspective, we nonetheless highlight some of the patterns found, as well as the main factors of risk exposure, or of protection, which are observable throughout the individual stories in a brief analytical synthesis.

The following analytical synthesis does not replace the reading of the histories, which reveals a set of successions and very important articulations in the production of school failure and in the construction of the school dropout.

\section{Early School Leavers not in employment, education or training (NEET)}

Life history 1. Laura (Croatia)

Life history 2. Olivier (France)

Life history 3. Sofia (Italy)

Life history 4. Isabel (Portugal)

Life history 5. Marius (Romania)

In the first 5 stories about early school leavers not in employment, education or training (NEET), who left the education system, we find a diversity of situations - ranging from total absence of school experience, as the case of Laura and Marius, to the frequency of secondary education, as is the case of Sofia. Laura and Marius did not in fact dropped out, they have never entered the system, in this way reflecting and showing the persistence of fragilities within European educational systems.

\footnotetext{
51 In this respect, the profile "Employed Early School Leavers" has 6 histories ( 2 collected in Italy), the profile "Young people who have returned to school or training after ESL or suspending" has 9 histories (2 collected in Croatia, 3 collected in Italy, 2 collected in Romania), and the "Young people enrolled in education or vocational training" profile has 5 stories (none collected in Croatia, 2 collected in France).
} 
In the personal paths of these 5 young people we can identify a number of interconnected factors contributing to the school distance or dropout. Mono-causal approaches cannot adequately explain the phenomenon of dropout. Rather, several influences can be taken into account.

For instance, home moving, change of school, variations in the family. In both cases of absence of schooling experience, the family represents either the port of refuge (Laura), or the problematic context that leads to the independent and precocious search for a different life, exposing Marius to new risks and problems such as delinquency and the consumption of drugs. The school is absent in this second case. Laura exercises her limited skills exclusively in the family context, but dreams of a school experience, which is hampered mainly by advanced age and language difficulties. As stated in the story of Laura, "the only thing she knows how to do is being a housewife". Laura perceptions of difficulty do not allow her to even try - she strongly believes that "Croatian school is difficult and that she wouldn't be able to keep up." Marius, in his condition of extreme marginality, with no papers and no house, does not seem to believe or take place in the school.

Isabel leaves school also because of the need to work and help her family, but, as in other cases, the school experience is interrupted following episodes of discrimination, bullying, insecurity, fear, which lead to a profound lack of motivation (Isabel, Laura). Other school contexts are described as places of loneliness and lack of attention, meaningless, as described by Olivier, a young man "in permanent conflict with his parents", who thinks that "school has no interest", and teachers "badly appreciate him".

Some narratives show the difficulties (or even the refusal) of integration in classes with younger students - the effect of repetitions seems devastating, and the age difference that the continuation of school paths implies is seen very negatively.

Vocational problems are also noted - lack of interest in the school or courses available, and difficulties in finding the desired options close to home. The praised schools, those that stand out, are small, familiar, spaces of acceptance and visibility. As described by Sofia, who had the opportunity to attend a small school characterized by "trainers particularly focused on the school and personal needs of the students", where "she felt immediately accepted". In this type of schools, students feel accepted, understood, part of a collective.

From the point of view of resources, which the histories also allow us to observe, we find both the importance of family networks (which stand for form of oppression, but also of protection 
and care), as is the case with Laura, Isabel or Sofia. We also find entrepreneurship skills, ability of money making, in very vulnerable and depressed contexts, as in the case of Olivier and Marius. Some optimism and a sense of the future, a certain hope to return, and a valuation of the school - although the school does not always have good professionals or professionals with the capacity to make sense of the school experience.

Their experiences of life lead us to point out the social lack of protection they are subject by the state. Marius even says that "this is the reason why we become stealers, burglars, liars, all these things. Because the government doesn't care about us".

Isabel and Sofia emphasize the need to transform school in order to enable teachers to defend the weakest and to appropriately correct aggressive behavior, prevent bullying, and to innovate in methods, bringing school contents closer to real life.

At the core of negative experiences, we observe dynamics of isolation, lack of sense of the school experience, fear, retraction and demotivation. Outside school, everyday life is repetitive, boring. However, a time which is useful for the family (in the case of Laura and Sofia), and sometimes, at a certain point, "the need to help the family is proportional to the lack of interest in school", as in the case of Sofia. On the contrary, at the heart of positive experiences are recognition, protection and closeness.

The histories also allow us to see the multiple faces and attitudes of these youngsters: they may steal for necessity, at the same time they protect the family from the fact that they are living in the streets (Marius); they clean the household while dreaming to become a fashion designer (Laura); or they raise their children while dreaming of doing better, of listening them say, one day: "My mother didn't study for this reason, but she got back to school and I'm going to do better than her".

\section{Life history 1. Laura}

Title: Never give up!

Profile: Early school leaver not in employment, education or training (NEET)

Source: Life history interview conducted in City of Osijek, Croatia, 8.6.2017

Laura is 17 years old; she comes from a Roma family which lives in a small village. She is an optimistic girl who believes in her future, but is also aware that first she needs to learn the language of the country she lives in.

Laura grew up in Italy, where she spent her early childhood living with her family in a camp house. There she didn't go to school, even though her mother tried including her in the local school. Laura remembers that they attended Italian classes together. But since they moved a lot, it was hard for her to join the educational system. Nevertheless, she knows how to read and write. 
Five years ago she came back to Croatia with her family but since she didn't know Croatian language, she didn't start going to school, even though her brothers and sisters, six of them, go regularly to school. In the meantime, she takes care of the household along with her unemployed mother, while the father is working. Her parents also didn't go to school although her father knows how to read and write.

Laura's day goes by in cleaning, helping her grandmother, taking care of her siblings, cooking, listening to music. Sometimes she works in the gardens with her mother. She applied to the unemployment bureau, but there is no job for her since she is too young and without qualifications. The only thing she knows how to do is being a housewife. She doesn't have a lot of friends, only one friend who also doesn't go to school, Laura believes because of her health issues. Often she is bored at home.

Laura dreams about becoming a fashion designer, she loves to draw and make her own models. However, she is aware that she should finish school. Her obstacle is language, which she speaks little. She thought about going to night school, but she can't do that without knowing the language. Once she went to local primary school where she had the opportunity to talk to a teacher who tested her knowledge of numbers and reading and established that she knows how to read in Croatian and that she should go to school. However, Laura thinks that Croatian school is difficult and that she wouldn't be able to keep up. Besides that, she was supposed to go to school with kids younger than her, and she doesn't want that. Her siblings are great students, but she can only dream about it.

At home they speak Romany language, but her siblings also speak Croatian very well. Even though her family doesn't think that it is a problem that she doesn't go to school, her grandparents highlight the importance of education. They often tell her that it is not nice to live without education. Also, against Roman tradition, they don't want her to marry too soon.

Once, when she is a mother, Laura would like to see her kids in school and being successful. She thinks that it is not only important to go to school, but also to learn something that they would love and grow their love towards their future job.

"I will never give up!", said at the end Laura.

\section{Life history 2. Olivier}

Title: Who could help?

Profile: Early school leaver not in employment, education or training (NEET)

Source: Life story interview conducted in Paris, France, July 28 2017

Olivier has 22 years old but is not any more in the school for already 3 years. From primary school to middle school, he had the path of a " good pupil " but it was at the high school that his problems began. He presents himself the causes of his unhooking as being bounded to " the atmosphere at the house " and to the "bad company". Olivier stopped his studies in high school and moved on with judicial troubles "once, I attended a police check of a guy which I did not know but the cops irritated me because they spoke to him badly, knocked him down. As a result, I went to see them and I said that it is not normal and thus they began to speak to me badly, I offended them and later they arrested me. It is the law of the strongest. I do not like the injustice ". When he is asked to describe a typical day he answers " not much. I sleep until 17 hours. I get up to eat, I go out to see my buddies ". He lives with his parents, his younger sister and his younger brother. He is in permanent conflict with his parents and according to him it is the reason why he does not like staying with them. He lives in the 19th district where he always lived but says that he came from "93" when we ask him, because his best friends live in this area. His parents tried to motivate him to join trainings but he was never up to the end. His father is 55 years old. He is a holder of the tub (ferry, high school diploma) and today is a taxi driver. Her mother who is 50 years old has never followed studies and chained various "jobs" in the catering, the sale and the household. She did a training course to become a nurse's helper. Olivier thinks today that the school has no interest and he just went there for "hanging out" (" trainer ") with his companions and friends even if he managed to take out good grades there. He never says to have loved the school but went there mainly so that his parents " do not annoy him ". He blames his failures to society, to his parents who 
"did not support" him in life, to the " bad teachers who are at the school only to charge at the end of the month ", but
especially to his family frame. He specifies: "I especially stopped because there are teachers who accused me
wrongly because I had bad appreciations. They have their pet (scrunchie) and just hated me by basing on what
colleagues had told them on me ". He expresses his need to be regularly supervised and supported. All that interests
him, he says, are the video games. He often finds his buddies to play for hours in the street or with one of them at
home. He manages to make a little money with " a small business " of sailing shoes and digital accessories which he
buys to friends and resells to others. He sells presents received from his family (telephone, shoes, watches). Olivier
says to be persuaded that he will, one day, create a company with his best friends.

\section{Life history 3. Sofia}

Title: Waiting for the future

Profile: Early school leaver not in employment, education or training (NEET)

Source: Life history interview conducted in Italy, Savigliano, 18 ${ }^{\text {th }}$ May 2017

Sofia is 16 years old, and is at home today, taking over from her mum when she is at work with housework and looking after her younger brother who goes to playschool. Initially she is shy, but after a few minutes she starts to relax and talk with ease.

She started primary school when she was five and a half years old, the first three years in a school complex in a small town, into which she integrated well, the last two years in another school in a larger city as her family moved home. After failing in middle school, she had to change class and consequently classmates; she felt disoriented and both her classmates and teachers were unable to understand her. Her classmates had always made fun of her for her teeth problems in both primary and middle school and this led her to becoming withdrawn. Sofia found it difficult to wake up in the mornings to go to school and therefore her attendance began to be rather irregular.

Furthermore, after some check-ups in middle school, experts acknowledged she had a specific learning disorder. The Italian teacher recognised she had more difficulty than others in the subject and had advised her family to assess her schooling capabilities. After obtaining certification, through the integration of compensatory and dispensary measures, her schooling assessments improved along with her school attendance.

In middle school, Sofia had a maths teacher who promptly intervened when he saw her classmates were teasing her, pointing out that everyone has slight flaws and therefore there was no need to remark those of others.

As her dream was to be a beautician, a profession she was passionate about since she was a child, she enrolled in a vocational training centre, about thirty kilometres from her home, which she went to by train every day. She felt immediately accepted in this school; it was small and the trainers particularly focused on the school and personal needs of the students. The Manager made his presence felt and was always willing to listen to everyone: boys and girls, trainers and school operators. The school climate was definitely positive, and her teeth problem had improved, thanks to the involvement of a professional in the field.

Despite the educational context being positive, Sofia left the school to enrol in another one on her mother's decision. Personally, Sofia did not want to leave, but her mum thought the school was too far from home and that she was too immature to face this experience. As a matter of fact, some problems had arisen with people she encountered outside the school context on her way to school.

At that point, her family had to search for a secondary school willing to accept their daughter, another beauty school in another city was already full and a professional training course in catering had no more availability, so the only possibility was to enrol in a professional school in her city.

When she arrived in this school in the second term, she willingly tried to make friends with everyone causing jealousy among the girls in the class and school, who, in their turn, started "spreading bad rumours" about her. The situation unfortunately degenerated, and Sofia suffered bullying outside school by both boys and girls of her school. Faced with these facts, the teachers intervened by promptly alerting her family, while the manager, did not take due account of the fact and her situation, minimising what had happened. As expected, her school attendance and her motivation decreased drastically, and she failed the school year. 
Sofia thought she could manage to attend school the following year, but unfortunately, it did not go quite like that due to the fear of meeting the same people who had bullied her. After this experience, Sofia believes it is impossible to build a relationship of friendship with classmates and schoolmates, she feels extremely insecure of herself and of others and she feels a strong need to always have someone she can trust and who can protect her nearby.

On her part, she acknowledges she had the wrong attitude towards both her school and schoolmates. From her point of view, she understands that as a student you need to "get on with your own life", go to school to learn, take school work seriously and have a more appropriate behaviour than what she had, it is important to show yourself as a "serious person" in the school environment.

Her family, along with a couple of friends, helped her face this situation, advising her to leave school because surely, she would have had the same type of problem in any other school. She also reflects that if she had enrolled in school again, she would have been in a class with younger classmates and this would have certainly caused further difficulties.

Therefore, from the next school year, Sofia remained at home to look after her brother and do the housework, which she does not consider a problem as she feels useful for the family. Her mother works for a cleaning company and her father is a labourer and they also only attended compulsory school.

Her dream is still to become a beautician; perhaps, when she reaches adulthood she can enrol in a course in this field in a private school, but now she has decided to take one day at a time. Her family is aware that education is important and believes they have left their daughter free to choose and only wants her to be happy and then, in the future, a job will somehow come along. Even Sofia often asks herself what she will do in the future and has decided to take a positive approach, aware of having the potential to express herself.

Some of her friend's work, one friend attends upper secondary school, her best friend, who also went to the same school as herself was also forced to leave because of the hostile environment and the inadequate behaviour of many of its students that are not appropriately punished.

According to Sofia, everything should start from the teachers, they should help the boys and girls to understand how weak people feel, perhaps by organising debates and discussions on the topic of bullying, so everyone can understand that also "little things" can hurt people. Faced with these facts, punishments should be appropriate, paying attention not to fuel the whirl of violence among students. The school should also do everything to protect the weakest children who risk exclusion.

\section{Life history 4. Isabel}

Title: Get a decent job

Profile: Early school leaver not in employment, education or training (NEET) Source: Life history interview conducted in Amadora, Portugal, 17/05/2017.

Isabel is 22 years old, was born in Portugal and lives in Amadora. She was involved in the project of the Orquestra Geração (non-formal programme of music education aiming to promote the social inclusion of students and improve their academic performance) but left it when she changed school and life demanded her other responsibilities. She is the mother of a 2-year-old boy and motherhood has made her rethink her relationship with school. She's a very outgoing young woman. Since the age of 15 she has guided her goals in order to achieve greater financial independence.

She doesn't study or work at the moment. But already had several professional experiences, mainly in restaurants and hotels. She failed for the first time in the 5 th grade, a period she describes as more "complicated" at the family level. In this school year, she changed house and also school. She suffered in this same year an episode of bullying that left her in a state of apathy - "I was here, but it seemed I wasn't" - and that marked her very negatively in her relation with school. A male colleague threatened her continually, and fear prevented her from asking for help. It was her mother who spotted the marks of an assault and reported the police. "I'm now 22 years old and he doesn't know me anymore, but if I go through him, I'll shake like a leaf, because he even put a knife around my neck." This 
episode of violence marks the beginning of a path that is afflicted by absenteeism, disapproval, failure and school dropout.

She has a closed network of friends, and highlights a best friend, still present today, who used to encourage her to study. This friend graduated from high school and had a linear and successful path. Her mother also encouraged her to continue the studies and was present at the meetings for which she was convened. Isabel reveals that she had many good teachers who influenced her positively, but also some who marked her in a negative way. For example, teachers who didn't motivate, who only "recited stuff".

In the 9th grade she attended an Education and Training Course (ETC), of which she doesn't keep good memories. It was this year that dictated the withdrawal from school. Isabel reports that she was part of the group of "bosses", the designation assigned to the group of older students. She gave up without completing the 9 th grade, because the need to help her family was proportional to her lack of interest in school. At that time, she was already working in a supermarket in part time, while studying. Reconcile the two wasn't easy and she chose to dedicate herself exclusively to work. Her child was born later; he wasn't the reason for dropout, but made it difficult for her to return to school. Isabel considers that at school they tried to find alternatives to keep her studying, by moving her from a regular course to an ETC. However, this solution was not effective. The economic needs of her family took on an urgency and dictated dropout.

Isabel's social and economic context is very disadvantaged. She currently lives with her mother and two younger brothers, her husband and son. Isabel's parents separated when she was a child and the father died about a year ago. The mother, who studied until the 4 th grade, stopped working as a pastry assistant for invalidity two years ago. The father studied until the 7th grade. She has five siblings, but only the youngest are still studying, while the three older ones have emancipated themselves. The older sister was the only one who graduated, in the area of kindergarten education, because most of her schooling was done at a nun's college in the north of Portugal, as a resident. The other sister completed the 9th grade via the RVCC (recognition, validation and certification of competences) and works as a bartender. The brother followed the father's footsteps, as a truck driver.

Isabel and her husband are the financial providers for the household. In addition to assisting the younger brothers, she also has her own child. She started working very early, at the age of 15 . States that "first I wanted independence, to have money to go out with friends and all that. Because they were going to the movies and I wasn't. Why did I start to work before having my child? To help my mother. Because she's a woman full of strength, but she can't work. She stays with my son and I work." Currently the mother encourages her to complete the 9th year of schooling, in order to find better jobs.

When she was a child, Isabel wanted to be a pediatrician. She still manifests this desire of relating with children, which leads her to take part in volunteer activities in day-care centres from time to time. Nowadays she would like to have a more stable job and recognizes that for this she had to invest more in her studies. However, the expectations regarding the school are not very ambitious. She wants to go back to school and finish her 9th year of schooling, which she plans to finish "in order to get a decent job". Above all, she thinks about the kind of life she will give to her son and imagines for him a personal and scholarly education different from the one she had: "As a mother, I already think about my son's future. I don't want him to be an aggressive person that gets into conflicts, but I also don't want him to be beaten at school and look to the other side."

In her opinion, school could "charm more" if it had more practical classes and field trips, as a stimulus and motivation. As part of the Spanish classes, she recalls with longing and enthusiasm a three-day field trip to Spain that coincided with her birthday. She evaluates this event very positively: "It was wonderful. There are no words to describe it. We heard people speaking Spanish on the street." To grab students more years in school, Isabel proposes greater ease and tolerance at school schedules for working students, similar to what is done at work when workers study. But the most important thing is to explain to children the importance of studying and that schools focus on other teaching methods that make school more attractive.

Isabel finishes the interview with her eyes on her son's future. She would like him to tread another way, being able to say later: "My mother didn't study for this reason, but she got back to school and I'm going to do better than her". 


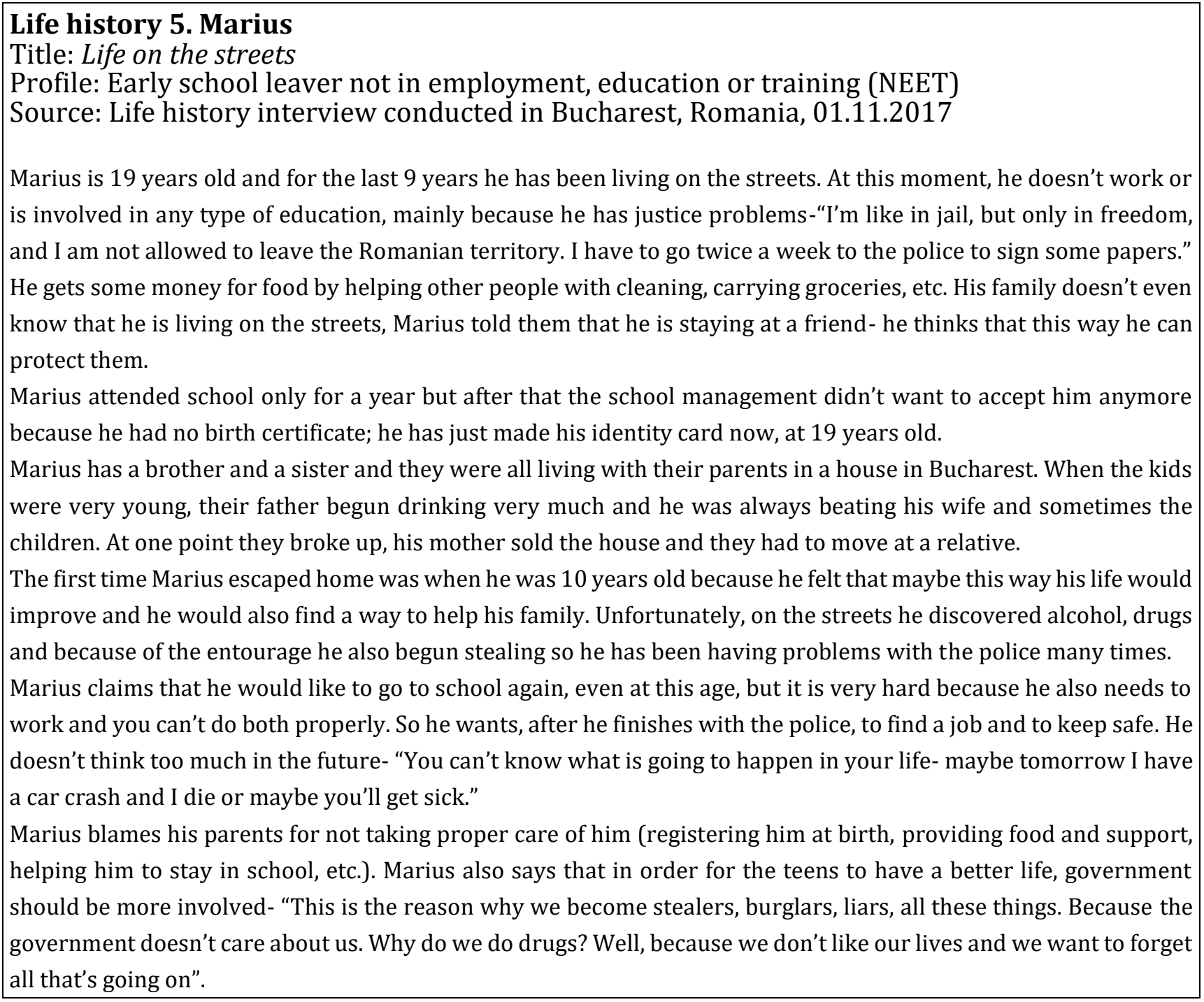

\section{Employed Early School Leavers}

Life history 6. Miroljub (Croatia)

Life history 7. Farida (France)

Life history 8. Luca (Italy)

Life history 9. Gianna (Italy)

Life history 10. João (Portugal)

Life history 11. Mihai (Romania)

In the Employed Early School Leavers we find 6 cases of young people with labor insertion (either full time or part time) who left the education system early. Again, reflecting territorial specificities, Mihai, a 16-year-old Romanian youth, only had a brief passage through school at the age of 8 , so he is not exactly an early school leaver. 
In common, they have the event of collecting vast work experiences, especially in the service sector, in many ways much more rewarding than school experience. Miroljub (Croatia) continues the family business at the request of his 70-year-old father, thus supporting his family; Farida (France) works in telemarketing, Luca (Italy) is a shop assistant (and is preparing himself to be an online player in the Japanese stock market), Gianna (Italy) has a steady job as a waitress, João (Portugal) is also a shop assistant (and has made some modeling), and Mihai (Romania) works part-time in a restaurant as a cashier.

The option to integrate the labor market was due to family pressure in the case of Miroljub, a great student with high school aspirations, whom the family asked - "go for work, work brings money!". Miroljub felt at that moment "very disappointed, helpless", but did not ask for help to "his friends, nor his teachers and so real life begins for him". He describes the transition to active life as an inevitability, and even as an advantage in the Croatian economic framework, where jobs are scarce for the young.

From a family point of view, we also find in this group of young people families affected by migrations, prolonged illnesses, changes, separations, losses, which in some cases increased the lack of protection and instability of the young. Gianna, for example, "hadn't told anybody of her family that she was having problems at school" for a long time. Some parents (themselves underschooled) attempt a close follow-up but find it difficult to find adequate or balanced methods of punishment and reward. Farida's mother used to put pressure on her because she thought that "she made nothing of her life, but even when I worked, she was not satisfied and said that it was not really a work". João's mother would check if everybody was studying: "I hated. I never really enjoyed studying. I pretended that I was studying and I was playing." João remembers that even if he had a good grade, his mother would always say: "you did no more than your duty".

However, integration in the labor market responds above all to a need to abandon an experience in which they feel repeatedly incapable. In the school experience of these youngsters we find cases of low aspirations directly communicated by teachers, discrimination and bullying, and many cases of repeated and early failure, as in the case of João, who failed for the first time at the age of 7, repeated two years in primary education, what "brought him a "revolt" feeling", "basically it provokes a revolt within the child". 
There are systematic difficulties with main school subjects such as Mathematics, hesitations and vocational pressures, processes of trial and error that have led to demotivation. Gianna believed that if she could not "do math it was because I was just dumb", Farida felt "stigmatized, isolated and physically separated from the other pupils".

The youngsters' paths show persistence and resilience, a series of attempts at new beginnings: Farida, for example, "thinks she was brave to stay so much time in the school in spite of her difficulties and she missed the support of the direction which only pulled downwards her". João really enjoyed a course, where "every day was a new thing", and considered that the most positive was the special bond with the class". But failure ends up making the young "rebels", as in the case of Farida, "frustrated me and made me offensive, a rebel", lethargic and incapable of reacting, as in the case of Gianna, who "didn't even try", dropped out of school and got a summer job working as a waitress", so she did not have to take a math test even after she had improved the grades in other subjects. She felt the need to "get away from everybody and everything".

Problematic school experiences were also reconciled with the loss of belief in the value of school as a vehicle of social mobility. Farida heard from her brother that "it is not because you go to the school that you are going to get on in life", and Miroljub states that even "if he had finished school he would have still be doing the same job he does today - he would run the family business".

Luca has found in the labor market a motivation for learning that he did not find in school, and has been exposed to situations that allow him to acquire skills, which provide "something really interesting that inspires and activates them [the skills]". Gianna traveled and worked in several countries, "mostly for the purpose of getting away from her negative group of friends and to prove to herself that she was a valuable person". In addition to her work she has Yoga classes and expects "to get a degree in philosophy, herbal or natural medicine" and "to teach Yoga" in the future.

However, in none of these youngsters do we find a speech openly against school or education. In fact, not all are far from school or complementary learning dynamics. Mihai is attending a second chance education program, just as Farida is taking private English classes. With the exception of Luca, who presents a critical and very thoughtful discourse on the limits of the educational system as it is constructed - "school does not teach you the freedom to be who you "want to be", it teaches you to follow a pre-established script that is the same for everyone", these young 
people generally aspire to a return to school, and they value it very much in their speech. Some of them await to have the courage to return.

For Farida, the most important thing is to see school "favoring the dialogue pupils-professors, making the link and avoiding confrontation". Mihai, with only a brief passing through school and a recent reintegration, has no doubt in stating that "if you want to be employed, have money and also have fun, without school is impossible". Luca believes "school should teach you what is useful in life, it should teach you to live."

\section{Life history 6. Miroljub}

Title: Every cloud has a silver lining

Profile: Employed ESL

Source: Life history interview conducted in Municipality of Erdut, Croatia, December 12 ${ }^{\text {th }}, 2017$

Miroljub was born on March $3^{\text {rd }} 1996$ in Vukovar, Croatia. During the interview he was very talkative and very open about sharing his story. Miroljub started secondary school in 2012 in Vukovar. He attended a Technical vocational school for three years. After finishing his first school, he decided to take up another vocational school to have a higher level of education. His first plan was to finish the fourth year and apply to the Police academy. The new school offers a friendly surrounding, teachers and his classmates welcomed him and he feels almost like at home. However, after the first semester, first problems occurred, not in school, but at home. Miroljub has been living with his 70 year-old father, who due to poor health wasn't able anymore to keep on the family business, stonemasonry. Miroljub is faced with one of the biggest life decisions, to continue school or to leave school and take over the family business. The father, as well as Miroljub, are aware of difficult living conditions, so the father suggests to leave school. Miroljub remembers his father telling him "Go for work, work brings money!" He is aware of the situation, feels very disappointed, helpless, but doesn't want to ask for help, neither his friends, nor his teachers and so real life begins for him.

Miroljub has never returned to school and is still working in his family business; he is now more mature, selfconfident and takes care of his father and their home. He has a girlfriend and is planning a family in the near future. Today three years after leaving school, he says he missed school and his friends when he left, he had no one to turn to. However, he doesn't regret, because even if he had finished school he would have still be doing the same job he does today - he would run the family business. Nevertheless, he advises all youngsters to finish school or go to university, because as he said "I left and today I am just a worker". Miroljub sees the state as the core decision maker which is to take necessary steps to stop the emigration of young people, who are leaving because they need work. The state doesn't motivate them to finish school to go to university or to find work.

\section{Life history 7. Farida}

Title: A lack of support

Profile: Employed ESL

Source: Life story interview conducted in Paris, France, July 27th 2017

Farida is 24 years old. She was born in Morocco where she made her primary studies up to the 5th year of primary school. She arrived in France at the age of 10 with her mother and her brothers and 2 older sisters to re-join her father who lived here for few years. Her older sister was the only one of the family who liked the studies but she had to stop it to work but she succeeds in her occupational integration. Her younger brother has a CAP level 
(Vocational training qualification) in pastry cook. For her big brother the school is not useful. He even tried to discourage her from going there by telling her "it is not because you go to the school that you are going to get on in life ". He works currently in pastry cook. Her second sister has stopped her studies further to her BEP (vocational diploma) and works today as a consumer advisor. She grew up in 93 district and lives there today with her mother and her younger brother. Her older brother got married as well as he left the family place. Her father died when she was 13 years old. She does not keep a lot of memories of him because she did not know him a lot. He used to go to Morocco from time to time but for short stays. Her parents did not make studies but Farida has globally a positive vision of the school even if she thinks that the quality depends strongly on the school frame, the professors. She states to have had no follow-up of her studies on behalf of her parents who do not know how to read or write. She regretted to have no family support and that her parents were not too much interested in the studies but just asked "do you have your diploma". There were almost no exchanges between the school and her parents except for punishments and delays. My mother wanted me to go farthest possible in studies because she thinks that it is the only way to have a better life.

She considers her route as atypical by basing on her negative experience in school: "the director denigrated me a lot, it was more a brake than something else". When she arrived in France, she did not speak very good French because she had begun to learn it in 2nd year of primary school in Morocco. It was a great difficulty for her and it was worst being directed by her French teacher in SEGPA ${ }^{52}$ in spite of the fact that she and her parents expressed their disagreement. The insistence of the direction eventually paid and Farida, who was in the $5^{\text {th }}$ level, was finally sent to SEGPA, 6th level, what she experienced very badly ("that has frustrated me and made me offensive, a rebel "). She wanted to drop out at this moment because her representation of the SEGPA is very negative and pupils there are stigmatized, isolated and physically separated from the other pupils who perceive them as "gogoles" (stupid). Having apparently an upper level than her companions in SEGPA, she made no efforts and had very good grades. She used to not re-aiming, what harms her, even right now. The death of her father occurred in the same period, what was only increasing her anger against the world which surrounded her. After the $3^{\text {rd }}$ year, she opted for a mechanical CAP (Vocational training qualification) because she says she was at time "a tomboy" and because she did not want to make a CAP but a general field diploma. She was identified as being in unhooking and was admitted in the MGI ${ }^{33}$ before making various internships in particular in the animation, medical and social fields. Farida then integrated a $1 \mathrm{st} \mathrm{SPVL}^{54}$ before dropping out. She worked a lot as seller in bakery and even today in a punctual way, the weekends. In the beginning, she wanted to work to have money but her mother put her pressure because she thought that she made nothing of her life (" but even when I worked, she was not satisfied and said that it was not really a work"). She does not go out for leisure activities a lot, her friends blame her for that. The latter jobs, were respectively in the post office, in the animation, in a pharmacy, etc. She does not manage to define well her professional project but she knows what she does not like to do. She says not to be fascinated also by something in particular but wanted to be a lawyer. Farida did not consider herself capable of making a success of this project because she tends to evaluate herself negatively, maybe because we often sent back to her this image. She selfcensors to make what she likes, saying to herself that she would not succeed. And the fact that she sees qualified people, with Master's degrees in the unemployment, does not encourage her. She does not understand why employers say to these people that they are overqualified. Diplomas become a handicap according to what she perceives. The positive points of the route of Farida in her experience in the MGI where two professors who encouraged her to forge ahead. She works at present at the telecom company as management assistant even if she particularly says not to like it. She also does a training course for English language in the evening, which she pays "a bit expensive" because she would like to leave studying abroad but does not dare to make it because she thinks her mother would be against it. She tells her she sets of the age and should get married as her sisters ("are yои a

\footnotetext{
${ }^{52}$ At the secondary level, the Segpa (General and Specialized Professional Education) sections welcome pupils with serious and persistent academic difficulties that have not been remedied by preventive and supportive measures.

53 Specific plan of the national education ministry since 1995 the "Mission générale d'insertion (MGI) identified early school leavers, coordinated actions, proposed solutions.

${ }^{54}$ Vocational high school diploma "Local services and local life"
} 
Hurdy-gurdy girl "). She is not very close to her mother. Farida thinks she was brave to stay so much time in the school in spite of her difficulties and the missed support of the direction which only pulled downwards her ". The director raised nothing positive in her capacities but underlined all the negative. She moved a few months upon her arrival of Morocco and changed school in primary sector but she was satisfied to leave her school because she was often victim of mockeries of the other pupils who called her "la bledarde" (small village girl).

To fight against the early school leaving and favour the success, it would be important to set up a mediation, according to Farida, for favouring the dialogue pupils-professors, making the link and avoiding confrontation. She thinks that the professors should listen more to their pupils and exchange more with them by avoiding to decrease, humble or push them. That was her case. The director of the SEGPA told her that she should drop out school after she was 16 years:" it was not compulsory any more ". She suggests reviewing the recruitment of the staff because there are some people who have nothing to do at school and who are there only to be paid.

\section{Life history 8. Luca}

Title: Yes, I can.

Profile: Employed ESL

Source: Life history interview conducted in Italy, Cuneo, 19 ${ }^{\text {th }}$ May, 2017

Today Luca is an aware and determined 24-year old man who is still living with his family of origin, composed of his parents, both graduated and a younger sister who graduated at the vocational school last year.

He started attending primary school, where he integrated well from the beginning, the teachers were interested in nurturing and developing his "real nature" that swayed toward a predisposition for art and design. The only negative experience of those years was linked to several "heavy comments" from his friends for his slightly chubby physique.

He started to have his first problems with subjects in middle school, studying the ones he liked with interest and neglecting the ones he considered useless and a waste of time. When he was 13 , his school year concluded "on a razor's edge". Luca remembers precisely that at the end of the third-year exams, the head of the examining board wanted to give him an excellent mark, but his teachers who had assessed his performance over the three previous school years decided to lower it to good.

Luca has no doubts about admitting that secondary school was a disaster for him. The only positive experience for him in that period was the class and school representative who allowed him to "have a role" within the school context. He had chosen a school that would enhance his design skills, but he just about managed to pass the first year and then failed the second. He repeated the second year, but on seeing his disappointing results during the year, his family decided to enrol him in a private school, which he finished with considerable difficulty. He passed the third year but failed the fourth year and the following class. At that point, Luca decided to leave school for good, with the conviction of being (incapable) and the sensation that "the world had fallen apart".

When he left school, he didn't think he was good at maths but now he has been studying stock market trading for three years to make investments. One could say he has achieved apparently unimaginable goals, exactly because of his skills.

After having dropped out of school, his parents, who had an artisan friend, asked him to take Luca on as an intern in his workshop. He accepted, and shortly after he employed him as an apprentice. Luca remembers that when he turned up at work the first time, he had no idea what he would have to do, but after a year's work, he realised that wouldn't be his life. The ideal thing for him would have been to find a job that ensured him economic independence, giving him the right amount of freedom. For this reason, Luca is now studying a Japanese stock trading system. He has partly achieved his goals and follows this project with two other boys. Above all, he doesn't feel the stress of the time when he didn't know what to do with his life and he feels proud because he has done everything on his own, an unexpected goal for someone like him, who, since he was a boy, everyone thought had poor self-esteem.

After long battles to encourage him to enrol once more in school, his parents gave up and accepted he would not get a diploma. Now, seeing him design his future home freehand, they continue to remark that he could have become a 
great surveyor and probably proceed to university. Instead, Luca is now more than ever aware that for whatever the school could have offered him, continuing his studies wouldn't have done him any good for his future. His opinion is that school does not teach you the freedom to be who you "want to be", it teaches you to follow a preestablished script that is the same for everyone. He believes school should teach you what is useful in life, it should teach you to live. Luca seems sorry for other boys like himself who, after having dropped out of school, cannot succeed in the way they would like, but he is proud of the path he took after dropping out because he has learned a lot on his own, and the road is now clear for its complete fulfilment.

On his part, Luca also shared the even more troubled path of his younger sister who traumatically went through her entire school experience starting from primary school, as she was considered "stupid" by her teachers. In middle school, she was found to be a girl with a specific learning disorder and, although with extreme difficulty and great determination, she managed to get her five-year diploma.

Luca's dream job is to become a stock exchange trader, it being a job, in his opinion, in which you are the creator of your own future. This idea is rather recent and has developed with a group of friends, some of which have already made it their main business. They have seen that in acknowledging even their failures, they could achieve their dream despite everything. For an insecure boy like Luca, managing to share skills and goals with other people was considered an unthinkable achievement.

Now he is working as a shop assistant in a toy shop, but has done other activities simultaneously, including network marketing for an American company in the field of nutrition that allowed him to experiment speaking in front of an audience pf nine hundred people at an international meeting. Another unimaginable goal for a boy with poor selfesteem as everyone had described him.

Luca believes that, to prevent boys or girls dropping out of school, a valid motivation to study must be given to them. Motivation consists in developing their skills, in providing something really interesting that inspires and activates them. Today, children have excellent intuition and immediately understand that what they are taught will not be necessary for their future. According to him, if they decide not to leave school, it is only because they have acquired the skills to learn and then forget what they have learned, in a few words, they have "adapted" to the current school system.

Luca believes that having teachers who are motivated is essential, but recognition of professionalism in school teaching is only through seniority and not for merit and this is a big issue. As a young man, the student wants his potential to explode, instead most teachers "suffocate this energy", channelling it into pre-established and obsolete schemes and modalities.

\section{Life history 9. Gianna}

Title: An emancipation journey in search of self, to break through to the other side Profile: Employed ESL Source: Life history interview conducted in Villafranca (Verona), Italy, October 24, 2017

This is the story of Gianna from Verona, 27 years old, reserved and slightly shy, a story that reflects a woman's deep sense of solitude, and her difficulty in breaking through to reach happiness and satisfaction. "At the age of 13, I decided to attend a university-oriented High school, a "Liceo", specialized in sociology, psychology and pedagogy she explains - to follow a friend of mine, a girl. I have a brother who is four years older than me, and back then he was attending a professional school specialized in commerce and technology. My mother, a housewife, never received a secondary school degree because at the age of 16 she became pregnant. My father, a truck driver, interrupted his education after middle school. And my parents separated when I was 11."

"The choice of attending a "Liceo" - she continues - was a good idea: I liked my peers and the subjects I was taking. I only had difficulty in getting used to so many new teachers and in dealing with mathematics. Already in middle school I had problems in passing math, and my teacher told me that if I couldn't do math it was because I was just dumb. In any case, up to my junior year in High school I always managed to pass the year by going to summer classes. 
My grades were up and down, I mean, I wasn't very good at school, with the exception of a few cases in which I did get good grades, when I felt particularly inspired."

At the end of her junior year, Gianna's mother contracted a disease, and she had to spend about a year in the hospital. "I was the only person who would go back and forth to the hospital, because my brother was off to a foreign country having received an Erasmus scholarship." And that's when life for Gianna started to become hard, physically and emotionally. Living just the two of them with her mother's ex-boyfriend, with whom she did not get along, Gianna would spend a minimum of time at home. "I would always hang out with my best friend, who had already dropped out of school and would spend all day doing nothing. Furthermore, I had a very negative group of friends, and I fell in love with a guy who was ten years older then I, but who had no particular feelings for me."

Gianna didn't manage to pass her final year at school, because she continued to skip classes. So, when she repeated the year, she found herself among new schoolmates and she didn't know anybody. In the meantime her brother had returned to Italy, and her father, who until then hadn't dealt with her school situation at all, decided to go and talk to her teachers. They told him that his daughter was about to drop out. Until that moment, Gianna hadn't told anybody of her family that she was having problems at school. Amidst factors such as her parents' separation, her mother's disease, and her brother's absence, her home was basically broken, her family structure fragmented. Her brother's return to Italy was consequently precious for her in gaining moral support from a person she loved, a person of great importance, i.e. someone to whom she could communicate her problems. "When my brother came back, my situation started to improve, and I would go to school every day. I was able to catch up with the others in several subjects, and I even found several teachers who gave me a hand, especially my pedagogy teacher. However, due to all the times I had skipped class, mathematics remained to be a big problem, besides I never really liked math. My teacher said that it was absolutely necessary that I pass math in order to be admitted to the final, exam of upper secondary school." Gianna didn't even try. She dropped out of school and got a summer job working as a waitress. She felt the need to "get away from everybody and everything".

After one year she decided to travel to London, mostly for the purpose of getting away from her negative group of friends and to prove to herself that she was a valuable person. After staying in London for a while, she moved to Australia, where she stayed for one and a half years. This was a learning experience as a traveler and professionally as a waitress. And then she returned home to Italy: "After three years abroad, I decided to return to Italy and go back to school. I wasn't really satisfied with being a waitress, but I needed - and still need - to be independent, so I need to have a job to cover my living costs. I want to get a high school diploma, but I'm afraid of the work involved, and I feel discouraged as I remember flunking in the past. Furthermore, life as an adult involves additional requirements." Currently Gianna has a steady job - waiting on tables as usual - nine hours a day. She goes to yoga lessons two or three times a week, and is living a normal life. She has a few dreams, possibilities for the future: to get a degree in philosophy, herbal or natural medicine. She would like to teach yoga. Gianna is aware of the fact that she first needs to get her high school diploma. She says that right now in her life she is on the threshold of returning to an academic situation. She considers schooling to be the only way to break through and pursue happiness. School would be a stimulus towards a life project. But she hasn't made that breakthrough yet, she still feels a wall in front of her. She still has to smash through that wall in order to start studying again, and sooner or later she's going to do it.

\section{Life history 10. João}

Title: Repetitions leave marks

Profile: Employed ESL

Source: Life history interview conducted in Amadora, Portugal, 6.06.2017.

João is 18 years old, was born in Portugal and is Afro descendant. Their parents come from Cape Verde and Guinea. He lives in Amadora, the city where he grew up and studied. He has been connected to the Orquestra Geração Project for about 9 years and has developed a special taste for a wind instrument: the horn. He entered the Orchestra in the 4th year of schooling by the hand of an older brother. 
He dropped out of school a year ago while attending the 2nd term of the 10th year. At that time, he was already working part-time, which seems to have been decisive in his decision to drop out of school. Currently, João works as a shopkeeper in a clothing company, with a part time work contract.

João's school path was irregular and marked by 4 repetitions throughout his schooling. Entrance to the school was smooth. However, with only 7 years, the 2nd grade marks a break in his school path, which will bring him very controversial feelings about the school. João failed twice in the 2 nd grade. He begins by assigning the reasons for his repetitions to himself and to the peer group: "problems of my head and also the influence of friends. I was really bad ... and influenced even worse." He describes the 2nd grade class as "agitated" and explains that in the transition from 1st to 2 nd grade there was a change of class because the 1st grade teacher left. The 1st grade class was divided and he admits: "I always had the bad luck to stay in the worst classes. Basically it was where the ruffians were at the time, that influenced everyone, and then they ended up influencing me too." He also points out that children at that time did not "have a good idea of what it was like to be in a classroom" and recalled that the games were carried into the classroom as in the kindergarten. Repeating a second time in the 2nd grade brought him a "revolt" feeling. At 8 years old, João had two school repetitions and he explains what he felt: "basically it provokes a revolt within the child." The change of teacher was fundamental, so that until the 4th grade his relationship with the school changed positively: "everything changed, completely. There was another teacher who managed to change me, even literally. A teacher who marked me up to 4th grade. (...) This teacher really put it in my head that the school is to study." In addition to the patience with the students, unlike the previous teacher who "screamed a lot", this teacher used "more activities" and the attribution of "prizes" in learning.

However, despite the better school results, until the end of the 1st cycle João's mother (in charge of education) continued to be called to the school to know about "minor" occurrences, such as João not returning the soccer ball to colleagues or upset the classroom. Still in the 1st cycle of basic education, João managed to overcome some difficulties that he had with Portuguese through support classes proposed during a school year. Never again did he experience difficulty in studying Portuguese in subsequent cycles.

Changing school in the 2nd cycle goes well and integration into the new school was facilitated through the Generation Orchestra, which João had been attending since the 4th grade. He remembers that in that 5 th year he had more free time "to play and to rest".

In the 3rd cycle, in this same school, João fails again twice in the 7th year. He recalls that he experienced increased difficulties in accompanying learning, although his behaviour improved considerably. But the second repetition in the 7th year contributed to discouraging and consequently aggravating the disciplinary problems. Absenteeism intensified at this stage, even though João was at school to play football or in the company of friends. The consecutive repetition activated what he classifies as "revolt", and explains: "I was sad, very sad. It's complicated, isn't it? I remember being punished for two weeks. My mother said, ok, you don't go to the beach. You stay home in order to reflect." In his third 7th year, João opts for a vocational course in music, computers and table service, and concludes his 9th year of schooling in only two academic years. He enjoyed the course, "every day was a new thing", and considered that the most positive was the special bond with the class. At this stage he never had problems reconciling the vocational course with the rehearsals of the Generation Orchestra.

At the age of 18, João enrolled in the 10th year, latter then expected, and attended only two weeks of the "Sports Management" course. This course was the only one that was available at that high school, and according to him: ""Sports Management" wasn't really my thing." So he did not hesitate to change when he was called to a course taught by IEFP [the public institute for employment and vocational training] in "Computer and Systems", which he got to know from other friends. The course did not motivate him to stay in school. He was already working since last summer. Initially he saw the work as an "internship", but quickly realized that he had a schedule to meet, sometimes at night, and that it was "serious work", with access to training. The attraction of "making money" and the disenchantment with the computer science and systems course referred to as "boring", ended up dictating the drop out from school.

Five people live currently in the house: the mother, João and three other brothers. Two brothers have emancipated themselves and one of them emigrated, works and lives in London. João has four brothers and a younger sister.

João's father, who currently lives in Holland, separated from his mother when he was not yet born, and João only met him when he was six years old. He had never had contact with his father since then and only spoke to him at the age of 17 . He grew up with the father of the younger brothers, a very significant presence to this day. His mother is 42 years old, is a hairdresser and currently is unemployed. She has gone through other periods of unemployment in recent years. João says it was difficult, but recalls "we did not ask for much and did not ask for the more expensive. Only now that we're working and buying more expensive clothes. We are those people who do not think only of us, we think of the whole family. (...) My mother also did well to always inform us about the things in the house"; and also highlights the financial and emotional support of a maternal uncle. João's mother had only the 6th year of schooling and a few years ago completed the 9th year through the New Opportunities Program. 
With respect to the schooling of her children, she always worried about the school results and was a regular presence in the various meetings of the school. Often divided by the meetings scheduled for the same days, partially attending to each other, never ceasing to follow the school life of her children. At home she stipulated an hour of study that required everyone to go to the study room, "and then she would stay there to check if everybody was studying. I hated. I never really enjoyed studying. I pretended that I was studying and I was playing." João remembers that even if he had a good grade, his mother would always say: "you did no more than your duty".

Often the older brothers took the responsibility of bringing the younger ones to school: "The older ones took care of me." Today João assumes this same role with the younger brothers. One of João's older brothers - who took him to the Generation Orchestra - was the only one to pursue higher education. Currently studying at ESML [Lisbon Higher School of Music]. Also three other brothers were connected to the Generation Orchestra. They all dedicated themselves to different instruments. When João failed for the first time, none of his brothers had failed. Only later happened repetitions in the family, but punctual.

João's network of sociability is almost always linked to the Generation Orchestra: "my friends are musicians only". The friends' universe is reduced and João describes himself as a "little bit shy" and "unsociable". However, leisure time is usually spent with these friends, and at weekends he usually goes to bars in Lisbon or attends jazz concerts. He maintains, along with his work, a one-off activity in a modeling agency for which he has already made two commercials.

His main goal is to enter military life, an ambition he has since childhood. However, this desire is conditioned to the correction of vision through surgery that he will have to undergo when he meets the financial conditions to do so. In the short term, João plans to return to school to take a professional course in the area of tourism or in the commercial area, and thus complete high school. Only then he will try to join a military career with higher qualifications in his school path. The plan to go back to school will still be in the condition of worker/student, but he admits to abdicate from work if he feels difficulties in conciliating with the school. The Generation Orchestra is already in stand by and João admits that his relationship with music "is getting lost". João's mother would like him to pursue higher education and always says to her children that she "wants them to do better than she did in life".

In João's opinion, schools can be better if they create more opportunities for young people. For example, making it easier for them to return to school after the age of 18, giving them the opportunity to attend the courses they wish on a day-to-day basis and not just after work. School should motivate students more and teachers should "try to understand the person and realize what he/she wants from life and try to figure out why he/she will leave school ... because there are people who leave school for need. It was not my case because we lived as we could, but I lived well". João concludes that he would have continued to study if there had been the possibility of changing courses during the 10th year, but to reprove or wait for the change of academic year seemed "painful" to him, so he opted to move away and dedicate himself to work. The decision to leave the course was not easy, but he confesses that he ended up feeling a "relief".

\section{Life history 11. Mihai \\ Title: Ambition for the future \\ Profile: Employed ESL \\ Source: Life history interview conducted in Bucharest, Romania, 19.07.2017}

Mihai is a young boy, aged 16, registered in the governmental program Second Chance for 1 year now. The last time he had contact with the school was when he was 8 years old and went for just two months to a NGO to learn how to write and read. His mother didn't approve letting him go there anymore because it was too far from home and she had to work so Mihai needed to stay home with his older sister. He learned to read and to write from his sister so when he came in the program last year he already had these abilities.

In total, Mihai has 7 brothers but most of them are working in England or Germany. He stays in Bucharest only with one of his sisters and with his mother. His sister graduated from high school so he looks up to her.

Mihai claims that now he just wants to learn, to do his homework and to build his future after he graduates from high school. He has the moral support of his mother- "My mom told me to do whatever I want to, because no one should ever constrain me to do anything, I alone must choose. My mother agrees with me in whatever I do."

Mihai appreciates at his teachers when they manage to help them learn but also have some fun. He says that school and education are really important because when you finish school you can have a well-paid job, you can even start a business, you don't necessarily have to be someone's employee. 
Currently, Mihai is working part time in a restaurant as a cashier and from time to time he gets some money from movie extras. In the future, Mihai wants to take some classes in order to become a hairstylist in England.

Mihai claims that children and teens nowadays dropout from school mainly because of the entourage but also because of financial reasons or familial problems (parents' divorce, etc.). He says that there should always be someone who these children can talk to (like a member of the family or a teacher), so they can understand the importance of education and that there should be more informative campaigns so these children would find out about the influence of school in one's life. "Personally, if I had the chance, I would tell a kid in this situation to think about his future, what he wants to achieve in life. If you want to be employed, have money and also have fun, without school is impossible. I didn't think this before but now I am more mature and I know."

\section{Young people at high risk of early school leaving}

Life history 12. Kornelia (Croatia)

Life history 13. Dieyna (France)

Life history 14. Lucia (Italy)

Life history 15. Pedro (Portugal)

In the group of "Young people at high risk of early school leaving", we find 4 life histories of young people with very irregular school paths. Kornelia (Croatia), a young woman institutionalized in a community, is in transition to a professional bakery course, after a period in which she was twice expelled from school. Dieyna (France) is going through a vocational crisis, trying to finish the high school diploma in which she already failed twice. Lucia (Italy) is doing a dual apprenticeship in hairdressing, a dream that came true after a period outside school. Pedro (Portugal) is about to give up the hairdressing professional course that he is attending under pressure, after a path marked by disapprovals.

In common, these young people have complex family situations, ranging from the absence of family structure, in the case of Kornelia, to the profound difference in the educational guidelines of the extensive maternal and paternal family of Dieyna. Kornelia has been learning to deal with the void left by the absence of family structure, which she sought to compensate with additive behavior and the connection to a group of peers as opposed to the school, because they made her "felt relaxed and confident". Her disruptive behavior resulted in two expulsions from the school and a foster family leaving, but she was placed in a community where she can have the necessary attention and support. She still dreams of going to live with her grandmother, but is now focused on supporting young people with the same problems, and joining a bakery school, since she "fell in love with baking because while making cakes she could escape in her imagination and it relaxed her". 
Lucia (Italy) also describes states of anxiety that made it difficult to adapt to school logics since very early and that blocked the ability to build meaningful relationships at school: "school environment was not suitable for her". For the most vulnerable young people, school system is particularly harsh and aggressive. In fact, school environment is not suitable for all, and some youngsters need a personalized attention and different and less massified models of school culture. In spite of everything, Lucia had progressed in schooling and made a vocational choice that, although imposed by the teachers, proved positive, and gave her access to a school where she "felt immediately comfortable, both with the other students by whom she felt immediately accepted, and with the teachers who were immediately aware of her needs and were helpful". She is currently studying in a dual system and "she is a hairdresser in a salon in her town and is realizing how much she is learning about this sector through practice".

Pedro has a similar history, since after several school changes and disapprovals, he joins a small project with a lot of personalized attention, where a teacher gives prizes to students who had fewer absences and where he "won several awards that encouraged him to improve behavior, results, and to reduce absenteeism". He finished the 6th grade without any negative mark and remembers the pride that at that time the father had in his school results: "he carried my grades in the car to show how I had passed with good grades". Moving on to the vocational system, he resumed absenteeism and failure. Pedro is one of a number of young people in this group who has an extended family that has undergone changes over time, affected by illness and unemployment, in which there are many responsibilities and stability is not always constant. Pedro describes a familiar everyday life with a very complex routine in which he assumes many responsibilities in the care of the younger ones. Reveals "an ambivalence between the role he assumes in school, as a student, of lack of accountability in relation to school tasks, and the role of caregiver at home". Despite being on the verge of abandoning a course he does not like and where he did not integrate, Pedro is "enthusiastic about the possibility to change course and the possibility of receiving a scholarship to attend the course".

These youngsters show very early difficulties. Pedro started to lose itself in the bigger and more complex school of the 5th grade, Lucia "failed the 1st year of middle school due both to her school performance and her attitude towards school itself".

The vocational component is very important in this set of students. Many show indecisions, lack of information, vulnerability to pressure from teachers, family members, and aggravated susceptibility to system problems, such as the absence or limited number of vacancies, or the 
inadequate supply of vocational courses. In this situation of vulnerability and demotivation, peer influence, family pressures to enter the labor market or the possibility of early money making pose serious risks to young people. Dieyna, for example, "works as seller in a clothing shop while waiting for the start of the school year but does not know yet what she is going to do", while her mother's family, aunts and uncles, "want that I stop my studies to find a job because for them, being the elder daughter of my mother, I should be able to help her financially".

Pedro believes that "school would be more attractive if young people saw their ideas put into practice", and "that teachers should be more concerned with students and ask "if everything is okay".

\section{Life history 12. Kornelia}

Title: My dream can come true!

Profile: Young people at high risk of early school leaving

Source: Life history interview conducted in City of Osijek, Croatia, 21.6.2017

Kornelia is a sixteen-year-old girl who enjoys cooking and baking cakes. Her dream is to become a baker and open her own bakery shop.

Kornelia is one of the six children that parents couldn't take care of. Her father got sick and her mother decided to go and live abroad but she couldn't bring her kids with her, only the youngest child. Their grandmother started taking care of the oldest sister, Kornelia and two sisters and an older brother arrived in a Children's home and after a few months they were fostered. That was incredibly hard time for Kornelia because she realized what was happening but she couldn't do anything about it. It was especially hard for her when she was fostered and got separated from her brother and sisters.

When Kornelia got in the foster family she was 10 years old. She went to 4 th grade of primary school. Despite of all the problems that were bothering her, she was an excellent student until the end of primary school. Kornelia's foster family lived in a small village. There she learned how to work in the field, to keep a household, to cook. There she fell in love with baking because while making cakes she could escape in her imagination and it relaxed her.

Kornelia was 14 years old when she enrolled in a vocational high school in a nearby city. She was very excited to meet new friends. She adapted well, it wasn't hard for her to keep up with classes and for the first few months she had very good grades. She made a lot of new friends and she was the favourite in her group of friends. She got especially really close with two students. The three of them spent a lot of time together even after school.

In the second semester of 1st year, on persuasion of her friends she became more and more absent from school. She felt like she didn't have anything to do in school, teachers became very boring to her, they talked too slow and it annoyed her so she started acting arrogant towards them. The principle of the school and her foster mom tried talking to her, they tried to explain the importance of education, her foster mom even brought her to the psychologist but to Kornelia everything was funny and she was more and more enraged that she was not allowed to have the life that she wanted.

She ran away from school often and sometimes on the way to school she would just turn and go to her friend who was over 18 years of age and lived alone in a small apartment near the school. At his place all of her friends, that didn't want to go to school, would hang out there. There she felt completely happy, finally somebody was interested in how she feels and what she loves most. In her friend's apartment they would watch movies, listen to the music and talk about interesting topics. There she smoked her first cigarette and drank her first beer. Every few days somebody from the group would bring some marijuana or grandmother's relaxing pills that they shared between 
them. Kornelia enjoyed consuming the opiates and alcohol because she felt relaxed and confident. She went to school rarely and rarely and the days she decided to go to school, due to the pressure from her foster mom, she couldn't do it without visiting her friend's apartment where she would drink a few beers or take an opiate so that it would be easier to go to school. Then she would often sleep at class or make some trouble and disrupt the class. At the end of the second semester she was expelled from school. When she found out about that, she felt a big relief. In order to get her away from the bad influence of her friends, her foster parents decided to enrol her the next academic year to a different high school in a completely different city. In that time, she spoke with her mother over the phone a few times promising that she wouldn't take any more opiates and that she would finish school. "The promise didn't last very long... ", said Kornelia.

Even though she was accepted very well in school by other students and by the teachers, she rarely went to classes and when she went to school she would disrupt teachers, make stupid things and behave aggressively. In school she made friends who were thinking the same thing as she was. There were seven of them and they were all together expelled from school in the second semester. Kornelia was completely indifferent of the fact that, because of her inappropriate behaviour and a big number of non-attendances, she was expelled from school.

The foster parents asked social services to find her a place somewhere else because they weren't capable of controlling Kornelia anymore. She kept running away from home, she was rude and arrogant, and often she would come home visibly intoxicated. She was situated in community where she was under supervision of educators, pedagogues and psychologists for 24 hours a day. At the very beginning she was furious that she couldn't use the phone, contact her old friends but now she is used to it and she has become aware that the grown-ups and other users of the community want to help her. She fit in wonderfully; she enjoys all the activities and obligations, especially the ones connected with cooking and baking. She has become aware of what was happening to her and she wants to help young people who are going through the same experience like she did. She is terribly sorry that she left school but she doesn't want to quit. In the fall she would like to start going to baking school and dedicate herself to that profession. In the near future she would like to live with her grandmother, finish baking school, get some experience and one day open her own bakery shop. "My dream can come true!", said Kornelia.

\section{Life history 13. Dieyna}

Title: "A complicated life"

Profile: Young people at high risk of early school leaving

Source: Life story interview conducted in Paris, France, July 28 2017

Dieyna has 19 and lives with her mother and her brother (17 years) and her 2 sisters ( 14 and 6 years). She arrived in France in 2011 and pursues since then her scientific mass studies. She is today in a phase of questionings and intends of to stop her studies. She undergoes since a few years already a strong family pressure and finds herself pulled between two cultures: the maternal circle of acquaintances and the paternal circle of acquaintances. " Mother's family, my aunts and uncles want that I stop my studies to find a job because for them, being the elder daughter of my mother, I should be able to help her financially (...). At present, they do not stop annoying me with the wedding idea. For them, I should quickly get married also because one of my cousins who is my age made it recently. On my father side, they made long studies and would like that I follow the same route but the problem is that they want me to change orientation and to go towards the literary series while I want to make medicine ". Dieyna has a will to make a success of her professional project but failed twice in the high school diploma, what her close friends translate by a bad choice of orientation connected to an overestimation of her level of intelligence. Their reproaches lead Dieyna to wonder about the pertinence of her choice. She intends to go more towards the jobs by the paramedical. She really has neither support nor encouragement. She finds some comfort only with her best friend who has almost the same route, even if she failed 1st year of medicine. This friend is beaten by his father regularly because of this failure and other differences on her choices. Today Dieyna works as seller in a clothing shop while waiting for the start of the school year but does not know yet what she is going to do. She inquired to follow a MOREA or a DAEU if she answers selection criteria. Besides her troubles bound to the schooling, Dieyna 
takes care of her sick mother, reached by a breast cancer and when this one is absent, it is her who takes all the responsibilities at the house. Her father recently married a 2nd woman in his country of origin and spends most of his time there. One of her brothers has regularly judicial troubles, and descents with the police in the place of residence as well as the trials traumatized the family, particularly his younger sister.

\section{Life history 14. Lucia \\ Title: One chance more \\ Profile: Young people at high risk of early school leaving \\ Source: Life history interview conducted in Italy, 24th May, 2017}

Today, Lucia is 20 years old and finally has clearer ideas about her future. She lives with her family composed of her mother, her sister and older brother in a small village in the countryside in an area that is flourishing economically. In a low and slightly scared voice she begins to recall her story and refers that she already realised in the second year of primary school that the school environment was not suitable for her: relationships with her schoolmates and teachers, didactic activities, rules and so on. She failed the first year of middle school due both to her school performance and her attitude towards school itself. Her schoolmates and teachers made her feel uncomfortable because of how they looked at her and related to her, to the point that she managed to establish a friendship with just one classmate. She had always had a very varied group of friends, more likely composed of more adult people because, in her opinion, they were less interested in appearance and more in the person themselves, compared to her peers. The third year of middle school was certainly the most positive, since it was the last year in that school and that, in itself, gave her more motivation. When it was time to choose her secondary school, the teachers advised her to enrol in a vocational school, although she would have been interested in attending the artistic lyceum as she liked to draw, photograph and felt talented in creative activities. Lucia followed the instructions of the teachers and enrolled in a vocational training course in hairdressing. Unfortunately for family reasons, there was a delay in enrolment and the course was completed, so she was referred to a training course in catering. Compared to middle school, Lucia felt immediately comfortable in the vocational training centre, both with the other students by whom she felt immediately accepted, and with the teachers who were immediately aware of her needs and were helpful. When she felt agitated and anxious, some teachers accompanied her out of the classroom to talk to her and calm her down; this made her feel listened to and welcomed and consequently she felt better. The educational environment, the relationship with her peers and teachers even made her "want to go to school", which was very strange for someone like her. Despite this, the training year did not end positively as she exceeded the number of hours of absenteeism allowed in the course due to family and health problems. The following year she didn't enrol again and spent the entire time at home, "without a reason to wake up in the morning". She felt she was going crazy, all that wasted time with just a weekend job, in which she couldn't be employed regularly for her young age, but which made her more active. Meanwhile, her situation at home had further complicated, as besides her mother, an older sister with a small child and a brother just a little older than herself had come to live with them. While she was unable to establish a positive family relationship with her mother and older sister, she managed to confide her concerns and anxieties to her brother every now and then. Her mother, just like her brother and sister went to work as labourers in nearby factories when they had finished their compulsory school education. When she was eighteen, Lucia had the opportunity to enrol in a dual training course in the field of hairstyling (which provided work experience already in the first year of the course), which she had desired since the end of the third year in middle school. Unfortunately, her mother did not agree as she thought it was an umpteenth waste of money, given her previous experiences. Despite this, Lucia, who is currently attending the second year, is proud of the choice she made and considers it the last opportunity to end her training and have a future work prospect. Her tone of voice denotes determination and the will to show herself, her family members and the world that she can succeed in life. At weekends, she is a hairdresser in a salon in her town and is realising how much she is learning about this sector through practice. She also has the feeling she is learning more of the professional aspect of this field compared to when she is training, especially for the particularly pressing timings required by the clients and the salon owner. In class, the only difficulty she has encountered is being the eldest, which, at times, makes her feel tremendously uncomfortable. Unfortunately, also this year's school attendance has not been so constant because of family and health problems, but Lucia is confident that she can finally complete this commitment despite everything. 


\section{Life history 15. Pedro}

Title: If I was in a course that I liked, I would study until the 12th grade

Profile: Young people at high risk of early school leaving

Source: Life history interview conducted in Amadora, Portugal, 15.05.2017

Pedro is 16 years old, was born in Portugal and lives in Amadora. Apparently, he's a reserved boy, but we quickly realize he likes to communicate. He has a special interest in sports, especially athletics. Through school he has participated in competitions that allowed him to obtain good qualifications in sports. Pedro also has a special taste for cooking.

He's currently unwillingly attending the professional hairdressing course and states that "it's not working at all". In the current school year, he has already been suspended twice for bad behaviour and in this final stage he's barely going to classes. The class materials for the hairdresser's course, bought by the parents, disappeared from the classroom and the lack of support to recover them that he felt from the school determined his distance from the practical classes. He has changed several times schools and courses and is planning a new change in order to complete his 9 th grade.

At the beginning of his school life he didn't present major difficulties. He had good grades in Portuguese and mathematics, although sports were already his favourite area. School problems began to manifest in the 2 nd cycle. Pedro failed twice in the 5 th grade and again failed twice in the 7 th grade.

He begins by describing the 5th grade as "difficult". He didn't want to go to classes and so he was missing school a lot. It's only by untangling the complex yarn of these years that one understands the context and the factors that contributed to the beginning of a school path marked by disapprovals and disenchantment with school. Pedro explains: "The first year was difficult because I wasn't used to ride with my backpack, with my backpack very heavy. Then I started to lose myself. And then I got lost. In the second year it was for too many absences too. It wasn't by stupidity; it was because of missed classes. In the third year, I was still living in neighbourhood X, my mother signed me up at school Y, and I had to go there every day on foot. I lost my enthusiasm, and well, I lost myself too. Then I was referred to Child Protection for the first time." He missed classes, but he stayed in school "playing" and he confesses that "then when I noticed the class had already passed". He accumulated behavioural absences due to indiscipline towards his colleagues and teachers, and says that the classrooms he attended were noisy: "we were all neighbourhood kids." However, he appoints all the teachers he had during his schooling and, above all, highlights those who marked him positively.

After the disapprovals in the 5th grade, he was sent to complete the 2 nd cycle in Project 12/15 in the Intercultural School. He finished the 6th grade without any negative and remembers the pride that at that time the father had in his school results: "he carried my grades in the car to show how I had passed with good grades". He underlines the importance of a Portuguese teacher who awarded prizes to students who had fewer absences. Pedro won several awards that encouraged him to improve behaviour, results, and to reduce absenteeism.

In the 3rd cycle, he had to go to another school to pursue his studies. He wanted to go to one school and his father signed him up to another school. In the 7th grade he enrolled in the "computer maintenance, photography and electricity" course. He didn't like this course and once again the absences dictated the withdrawal of school and consequently the disapproval. He reveals that he was missing classes to "play ping-pong" or go "strolling in the parks". He changed school again and enrols in the hairdressing course he currently attends.

Pedro lives in a fragile and disadvantaged social and economic context, with his parents and five of his seven brothers. The two older brothers have emancipated themselves. The eldest brother is 23 years old and the youngest sister is 3 years old. The father finished the 4 th grade of schooling and the mother the 6 th grade. The father is currently unemployed, and the mother, after a long period of unemployment, has restarted working as a kitchen helper in a cafeteria. 
Pedro's third oldest brother is also at risk of dropping out school. The younger ones continue to study, but almost all register disapprovals in the school paths. Only the second oldest, currently a professional soldier, completed the 9th grade and never failed.

Despite the enormous difficulties he has faced, school supports have emerged on a timely basis, such as tutoring or support to do homework in community spaces. He acknowledges that the tutoring he received during a school year was important to change his behaviour. In the family he appealed occasionally to his father, but he confesses that avoids it because "he has a very rigid way of teaching. He tells you to do something and if you don't he "pumba" [attacks]. The mother, who is the tutor, goes to all the meetings for which she is convened, of all the children: "she couldn't stay until the end, she went to each one of all [brothers] a little bit."

Pedro reveals an ambivalence between the role he assumes in school, as a student, of lack of accountability in relation to school tasks, and the role of caregiver at home, within the family, in the assumption of household tasks and in the organization of the family space. He summarizes his daily routines: "When my father wakes up at 7am to take my mother, he always wakes me up. You see, I have responsibility. I wake up the kids, dress them and take them to school. Then I go to school and he [father] takes care of the others. While he's dealing with some, I take the others. I wake up in the morning, dress my brother to go to the ATL [leisure activities], the one who is 6 years old. (...) Washing and extending laundry, or it's me, or it's my father. (...) On Tuesdays and Fridays the kids have gymnastics and I have to prepare them their training pants. I take my brother to the ATL at 8am and I go to my school. I start at $8 \mathrm{~h} 15$ and leave school at 16h45. I get home, I fix my room and see what there is to do. If there is laundry to catch and extend, I do it, if there isn't, I sit on the couch waiting for my mother to arrive. My mother brings dinner. She brings soup and heats it. On Mondays, Wednesdays and Fridays I go to trainings with the youngest. I come home, have dinner, and each one cleans the kitchen in turn. (...)"

With the support of the Family Support Office (GAAF) of the school he currently attends, he sought and enrolled in another vocational school. He has chosen three courses as options: car painting, car panel beating, and cooking. He doesn't count on the encouragement of the father, who considers that the enrolment in this school will be another "waste of time", unlike the mother who considers that one should give "the benefit of the doubt". Pedro is enthusiastic about this change and the possibility of receiving a scholarship to attend the course.

As for the future, he states: "if I was in a course that I liked, I would study until the 12 th grade. But in courses that I don't like, I just want to be 18 and nothing else." He believes that if he had entered one of the courses he really liked, his career would have been different. He shares that he thought about giving up school, especially in this school year.

Pedro believes that school would be more attractive if young people saw their ideas put into practice and therefore proposes that schools provide a box in which students may register and leave their ideas. He also suggests that schools should have the courses that youngsters want, that classes should have a maximum duration of 45 minutes: "Classes are very long and there is very little time to be outside", and that teachers should be more concerned with students and ask "if everything is okay". Finally, he suggests that schools should organize more activities for and with the students in order to motivate young people, for example, Peddy Papers and Mathematics Olympics.

\section{Young people who have returned to school or training after ESL or suspending}

Life history 16. Aleksandra (Croatia)

Life history 17. Maria (Croatia)

Life history 18. Anna (France)

Life history 19. Marco (Italy)

Life history 20. Chiara (Italy) 
Life history 21. Denis (Italy)

Life history 22. Mariana (Portugal)

Life history 23. Ciprian (Romania)

Life history 24. Felix (Romania)

In the group of young people who have returned to school or training after ESL or suspending we find 9 histories.

They have in common the experience of having abandoned studies, at some point in their trajectory, but are now enrolled in education and training modalities. The reasons for abandonment are diverse. For example, family crises (losses, illnesses) or family responsibilities, as in the case of Aleksandra (Croatia), who was an excellent student, and became pregnant in adolescence. In that moment, "everything turned upside down" and her life was "never the same again". Felix (Romania) left school at the age of 9, just two years after entering, "for spending time at home and taking care of his mother who suffered from mental illness". Mariana (Portugal) faced her parents' divorce, became discouraged, started a cycle of disapprovals, and allowed the casual work with her mother in catering activities to gain space, little by little, as an alternative to classes of younger colleagues, meaningless school activities, and teachers who "did not want to know either. They were just there to teach". As she stresses "I would rather make money than go to school. I preferred to earn my money to buy my things because my father would not give me anything and my mother almost could not. So I always had to work to buy my things. I would rather do it than go to school."

Dropping out studies is also linked to school difficulties and the difficulty of schools to respect different rhythms of student learning. The school experience lost its meaning for Maria (Croatia), who "simply didn't like going to school, she considered studying by memorizing everything useless, and she despised that system". Ciprian (Romania) left school because he did not understand "anything from what the teacher was telling us - thus, I was not able to learn anything and decided to quit". A relationship with a violent and abusive teacher generated in Anna (France) a strongly negative image of herself, leading to depression, demotivation and conflict with parents, until abandonment. The discrimination and teasing suffered by Marco in school, and the lack of identification with the school culture, led him progressively to great isolation and depression. They also put him at the mercy of a football coach who "destroyed him from a human point of view" because he was used to insulting him in front of his teammates when he made a mistake; up to a point where he could not face the work overload, and 
"shutdown his brain", dropping out of school. Chiara (Italy) also found it difficult to adjust to the pace of school, to systematic conflict in the classroom, and demoralized after contact with an extremely demanding and severe teacher. She "felt overwhelmed by this situation to the point of not wanting to go to school anymore and of developing a growing hatred attitude towards studying".

Another recurring factor that emerges with great intensity in this group is vocational problems and challenges. This is the case of Chiara (Italy), who was referred by the teachers for a vocational course, and considers that "When you read, clearly written, that you are only worth a vocational school, you set a line telling yourself that you can't go any further. Maybe it's true that a person needs to be down to earth, but at that age adults should motivate you". The sense of inadequacy in relation to her vocational path, lead her to drop out her studies.

This is also the case of Maria (Croatia), prevented by her grandmother from pursuing the area of studies she liked, arts. Demotivation with the school led her to a spiral of misbehaviour, association with peer groups with oppositional behaviours, absenteeism and abandonment. Emotionally, and already before this transition, Maria "was very unhappy; she felt like she didn't belong anywhere, she was a real rebel." Vocational changes have sharpened this situation and led to abandonment.

Denis (Italy) attempted several vocational options, in diurnal and nocturnal schooling processes, from influences such as teacher pressure and closeness to home, always unsuccessful, until towards "all the troubles and the thousand doubts that raised during his scholar path", "his interest for psychology remained, but his self-esteem and the will to fight for his own ambitions fainted away as his desire for studying decreased". He was alone, without the help of his family, in the decisions he made.

The processes of return to learning dynamics are always linked to one or several changes. In the case of Denis (Italy), a change in the practice of sports led to the construction of a new group of friends, more qualified, who exerted a very positive influence, and helped him to "become a man", without letting yourself give up".

In the case of Aleksandra (Croatia), it was a decrease in family responsibility, since her mother took care of the baby so she could return to school, attend classes regularly and finish schooling. Even so, it was not easy, since "it was very hard to attend classes, to run back home and take care of my baby, to be a student, a teenager, mother and wife, all at the same time. But I'm a super 
mum, so I did it!”. Also in the case of Felix (Romania) there was a change, since it happened to go live with the uncles and to be free of the responsibility of taking care of his mother. This change associated with the support given by his kickboxing coach convinced him to go back to school.

Maria (Croatia), another case, was institutionalized and within this stronger structure she was able to find out what she really enjoyed doing, cooking, having entered a cooking school. Anna (France) and her mother were supported by a local organization, which helped in the choice of an alternative school. The entrance to this school constituted a turning point - if before she felt that she was treated like a "stupid, not intelligent pupil", now she gets along well with her companions of the current school and has a good image of the trainers, who are "listening".

Returning to school is sometimes the last and the best option, after having exhausted the options out of school, after experiencing trajectories of emigration or attempts to enter the labor market without success, as is the case of Chiara and Mariana.

Working and experiencing the condition of a worker changes the way one views life. Marco returned to school convincingly after working for a year with his father in the countryside. The experience he had has made him understand that a solution to stop school dropout could be to allow whoever has the intention of leaving school the experience of working in a factory or in the countryside, to truly understand what is waiting for them in the world of work and to "give value" to the opportunities that school offers.

After the experience they had, they have some considerations to share about what school should do to avoid the failure of their students. Marco remembers a religion teacher who "taught how to live", taught about life during his lessons and even stopped to talk in the corridors or outside school with those who did not attend his lessons. Ciprian, who dreams of becoming a firefighter because he "wishes to save people", remembers that "teachers should be calm and nice with the pupils in order to attract them to come to school". And continues, "children may be affected by the problems they are facing home and might not be able to learn at a fast pace like other kids. Therefore, all children need care and attention in order to perform well in school".

As Chiara stresses, "it is important for young people to learn how to listen to their ambitions, to understand what they want to become without letting themselves be conditioned; as adults, we must leave them the possibility to make mistakes and we must acknowledge their right to "a second chance". 


\section{Life history 16. Aleksandra}

Title: If I could turn back time

Profile: Young people who have returned to school or training after ESL or suspending

Source: Life history interview conducted in Municipality of Erdut, Croatia, December $5^{\text {th }}, 2017$

Aleksandra was born on 8 November 1994 in Vukovar. Today she's married and mother of two sons, lives in Dalj with her husband and children. At first she shows surprise to be asked to tell her story, but was very talkative and open to share her experience.

Aleksandra remembers enrolling to Secondary school in Dalj. Everything was fine and her life seemed to be just an ordinary life of a teenager of her age. At that time, she lived with her parents and her sister. Very early, at the beginning of first grade secondary school she entered a relationship. At the very beginning of $1^{\text {st }}$ semester of the $2^{\text {nd }}$ grade she got pregnant. "Everything turned upside down for me. I didn't have a clear idea of what to do or what to expect", she said. Her parents and her boyfriend respected her wish to keep the child. Aleksandra continued school until the end of semester but due to her condition she had to leave school. She remembers that it was very hard for her, it was only then when she realized that her life will never be the same again. Meanwhile, Aleksandra got married to her boyfriend and moved over to his parent's house. This was another new situation she felt not very comfortable in. "I felt like I was an observer. I didn't feel a part of my crew anymore. They went to school, to parties, had fun and I had to visit the doctors and had worries of somewhat different kind", she said with laughter.

Then the baby came. She remembers it to be the happiest and the hardest time of her life. However, very soon she made a decision - she wants to go back to school. Aleksandra said she could have never succeeded if it wasn't for her parents and her husband who were very supportive. Her mother took care of the baby so she could return to school, attend classes regularly and finish school, which is the most important.

"It was very hard to attend classes, to run back home and take care of my baby, to be a student, a teenager, mother and wife, all at the same time. But I'm a super mum, so I did it!, she said.

Aleksandra finished school with very good grades and graduated with excellent grades.

Today she is a confident young woman, mother in the first place and very proud of her achievements. He sons are her biggest achievements, she said. She still lives in Dalj with her husband and children, works and feels content with her life.

However, she ends the interview with the following sentence: "It I could turn back time, everything would be different now!"

\section{Life history 17. Maria}

Title: Opportunity to start living alone

Profile: Young people who have returned to school or training after ESL or suspending Source: Life history interview conducted in City of Osijek, Croatia, 21.6.2017

Maria is a seventeen-year-old girl who has interest in art ever since she was little, but as she didn't have any support to follow that interest, she finished a three year cooking school at Open University (vocational training center) and she prequalified to a commercialist so that she could have a four year education and take the matriculation exam. Currently she is waiting to pass her final exam. She works in a fast food restaurant; she lives alone and considers herself a happy person.

Maria lost her mother at a very young age, and her father abandoned her when she was only five years old. Her grandmother started taking care of her. Until 5th grade of primary school she was an excellent student, but as she started puberty she had less interest in school, so her grades were getting worse and worse. Due to the life circumstances in which she grew up in, Maria was more mature than her peers, she felt like she was older. As she 
grew up, she didn't have any topics to talk with them. Her social life transferred outside of school where she was surrounded by older teenagers and young adults. In primary school she started smoking and consuming alcohol. Even though Maria had problems in school, her teachers tried to help her finish her education and they achieved that. She thinks that if they didn't help her as much that she would have tried more and finished primary school on her own.

Maria ran away from her home first time in the 7th grade of primary school and by the end of her education that became a habit to her. She was very unhappy; she felt like she didn't belong anywhere, she was a real rebel.

After primary school she wanted to enrol in art school, but her grandmother talked her out of it, saying that she couldn't be able to live well with that job. Her friends didn't support her either. After her grandmother's persuasion, when she was 14 she enrolled in veterinary high school.

Because of Maria's rebel behaviour, teachers and other students started looking at her as a problem. She was the only one in class that didn't respect authority, she commented on everything, she was looking for reasons to start an argument and more often she became absent from school, so after a few months she completely gave up. In the next academic year, she enrolled in postal and telecommunications high school, but soon she gave up on that too. She simply didn't like going to school, she considered studying by memorizing everything useless, and she despised that system. She hung out with people who were thinking the same things and who also suggested that the educational system is useless and is based on unnecessary knowledge. Today, she still has the same opinion about regular education. She thinks that regular high school education kills the spirit, because there is no motivation and that young people when they are 14 and 15 still don't know what they want, and they are expected to choose a profession which will be good for them for the rest of their lives.

In the time when she didn't go to school all of her days were the same. She woke up early in the afternoon hours, met up with friends with whom she consumed marijuana on daily basis, came home to lunch and then went out again until late at night. Then, she was only 15 years old. She was brought up to the police station a few times for disturbance of public order and peace and also for possessing a smaller amount of opiates. Municipal court took away the custody of Maria from her grandmother and she was transferred to a Children's home. It was really hard for Maria to deal with that sentence so she was admitted two times at the psychiatric department of General Hospital in the town where she lives. "Now, it is hard to think about it", said Maria.

She couldn't adapt to the rules of the Children's home so she asked for a transfer to community where she was under the supervision of educators, pedagogues and psychologists. In the community, where she arrived when she was 16 , she found understanding and help. She started realizing her problems and became aware of how her path is difficult because she comes from a dysfunctional family without real parental care. She is very grateful to the employees and users of the community who helped her get back on her feet. She discovered that she likes cooking, so she enrolled in a cooking course at Open University which she successfully finished and immediately started working in her field. That gave her the opportunity to start living alone and prove to herself that she can take care of herself. In order not to get back to her previous state, she ended all contacts with her old friends and now she is surrounded by happy and positive people. They encouraged her to continue with her education. At the Open University she prequalified to a commercialist and soon she is planning to pass her matriculation exam.

\section{Life history 18. Anna}

Title: "Hope"

Profile: Young people who have returned to school or training after ESL or suspending Source: Life story interview conducted in Paris, France, July 12 th 2017

Today Anna is taking back a training after the have stopped her scholarship for a while. She was dismissed by the school after her 16 years but was able to take back a training. She is 18 -year-old. She keeps one very bad memory of her route at school and she still cries when she evokes this past. She was victim of violence on behalf of one of her professors whom " knocks of dictionary on the head " and in spite of complaints of the parents the direction did 
not react. Based on her experience at school, she built up a strongly negative image of her " I was manipulated by my classmates who are intelligent while I am a shit and I know it". Anna depreciates herself particularly when we speak to her about her qualities which, according to her, are not, (" I know how to speak English, I travelled but a lot is useless, I would have liked being intelligent, to have a Master's degree but I know that I am hopeless"). Anna made a run away from her parents' home. She would have undergone a strong pressure of her mother who told her " to move rather than to stay at home doing nothing ". She "had enough" to have no resources to fulfil her needs, she wanted to know what she could make to take out there. This is the way how she got in touch with the "Mission locale" , supported by her mother who accompanied her at the first appointment. She was not specially motivated go back to studies but the advices of the social worker and her mother urged her to go there. His father helped her to establish her application form. Further to it, she had a positive answer to enter this school while she did not think of it. Anna thinks that entered this school was a turning point of her life. What matters according to Anna it is that we do not decrease her:" I am a complete moron in math but I do not like that to be told". Anna arrived in France in 2000 adopted by a French family which already had a biological child. The latter with whom Anna maintains a complicated relation, she calls him " my false friend " and who is preparing a Master's degree. She comes from Romania where she never has been to school due to a serious illness which almost cost to her life. She was aware of her school delay upon her arrival but does not understand that the teaching team treated her of "stupid, not intelligent pupil".

She gets along well with her companions of the current school and has a good image of the trainers who are " listening". She regrets having been forced to leave the school and would have liked continuing her passage in SEGPA where she had a professor who took time to explain her choices without humbling her.

Anna's main problem is a lack of concentration but also a trauma further to her school experience.

\section{Life history 19. Marco}

Title: Strong family roots

Profile: Young people who have returned to school or training after ESL or suspending

Source: Life history interview conducted in Cuneo, Italy, 19 ${ }^{\text {th }}$ May, 2017

Marco is a 19-year-old tall boy with thick hair, an athletic physique that conceals his passion for football. He lives in a well-rooted family in a little village in the countryside with his mother who is a teacher and his father who is a farmer and an older sister who is sailing through university. From the start he seems very comfortable and very willing to talk about himself.

His story begins with the primary school, which went well for him. His performance was always rather good in all subjects, especially scientific ones. His mother, being a teacher, helped him a lot with studying in those years. Marco still remembers the afternoons going over lessons while playing football. That's exactly when he started playing football, an unbridled passion for this a sport that has characterised his life up to now. He didn't get on very well with his classmates, some of them really teased him for his "sticky-out ears" and his long hair. Each time it happened he wanted to face them "head on", unfortunately he couldn't. What Marco calls the "decline" began in middle school: school assessments drastically dropped and the negative atmosphere in the class also made his desire to go to school drastically decrease. Behind the teachers' backs, some of his classmates often teased an autistic companion and he saw himself reflected in that experience and would have liked to rebel, but he felt alone and helpless and so at home in his room, he would "speak to his football" to let off steam. Exactly in that period, Marco had found a green area, along the river near his home that became "all his" and he started to keep it clean: creating a shelter and bench where he could be himself again, speak out loud, bathe in the stream.......a secret place to be revealed only to few trusted friends.... Marco talks about it naturally without the fear of feeling judged by the listener.

In the third year of middle school, his secondary school choice was between a school specialising in sports, considering his aptitude and a technical one, to ensure himself the possibility of getting a job with a diploma. After reflecting quite a bit, Marco chose the latter as his intention to go to university wasn't clear in that period. The first 
two years at the secondary school went well with good results, he was in a mixed class and he immediately picked out a "special" companion; he felt on the same level as her and she shortly became his best friend.

At a certain point with football, there was a bad moment in which the idea popped into his head to give it up because of a problem with the coach, who "destroyed him from a human point of view" because he was used to insulting him in front of his teammates when he made a mistake in training and during a match. Fortunately, Marco could count on a family that was always ready to support him and his deep passion for football, allowed him to "go further".

In the two-year period at school, many very different teachers alternated, some who were poorly prepared on the subjects and just as lacking in motivation in the job, others who were prepared and engaging. Among them, Marco remembers a religion teacher who "taught how to live", he taught about life during his lessons and even stopped to talk in the corridors or outside school with those who did not attend his lessons, to get to know them and exchange just "some chitchat" with them. From the third year of secondary school, Marco had difficulty in managing the workload of homework. When he left school he had good intentions, but once home he "shutdown his brain", spent his afternoons playing the PlayStation, or he plonked himself in front of the TV or even lay on his bed looking at the ceiling without doing anything. It was exactly on one of these days that he had the idea to drop out of school, driven by the economic independence that a job would have ensured him and by ever-disappointing school results. Almost miraculously, the year ended with a pass. With his voice trembling a little Marco recounts that it was in the fourth year that he "hit rock bottom", he no longer had the motivation to "remain at that desk in school". He knew deep down how difficult it would be to return home and tell his parents his intentions (for his mother, as she was a teacher, it was natural he would regularly finish secondary school); his grandparents (the relationship he had with his grandfather was like a paternal one, he had a lot of respect for him), his friends, the people from his village, a small one where everybody "gets to know everything about everybody". Everybody would enquire into his reasons for dropping out, they would certainly push him to return to school, maybe choosing the possibility to attend an evening course, even Marco new in his heart "he was wrong". After having expressed his intention to leave school, the only person who said nothing to him was his father, he simply asked him to turn up at 5 the following morning, ready to go to work in the fields with him. From that moment, Marco started to undergo the hard work of a farmer. Now his voice is clearer and stronger, Marco does not think it was wrong to do that kind of experience because it allowed him to understand exactly what his father's job consisted of to "keep his family". After a few months working in the fields, Marco decided in June, with conviction, to go back to school.

Obviously, the news made his entire family happy. He enrolled once again in the fourth class in September; the class and his new companions welcomed him, and the year will end positively. In the meantime, is plans have changed and he is thinking of enrolling at the university. The experience he had has made him understand that a solution to stop school dropout could be to allow whoever has the intention of leaving school, the experience of working in a factory or in the countryside, to truly understand what is waiting for them in the world of work and to "give value" to the opportunities that school offers.

\section{Life history 20. Chiara}

Title: From a failed educational orientation to the rebirth of ambition

Profile: Young people who have returned to school or training after ESL or suspending Source: Life history interview conducted in Villafranca (Verona), Italy, July 12, 2017.

Chiara is 22 years old. She grew up in a family by which she felt encouraged and supported throughout her life. The shyness revealed at the beginning of the interview, soon leaves place to grim, energy and confidence in the future. Both Chiara's mother and father hold a degree. Her grandmother, to whom C. is particularly bond, worked as a teacher and helped her overcoming her writing difficulties as she had a rough start at primary school, due to fact that she was left-handed and misspelled words writing them right-to-left. Overcoming these difficulties, thanks to her grandmother's help, C.'s performances at school became quite good throughout all her academic path. Therefore, the reason why she left school was not related to poor academic performances. Instead, from lower secondary school on, real obstacles lied in the learning environment she found herself involved in. Even having the 
attention and support of her family, C. got deeply influenced by the conflictual environment she experienced during classes in her school career. She recalls it and tells about the strained relationship with her classmates and with teachers. Due to the presence of some boys who were in systematic conflict with each-others and with the professors, C. felt that her teachers failed in supporting their students in such a difficult age. Particularly, she remembers her literature professor, who was extremely demanding and severe in judging and evaluating students' work. Even if unintentionally, this professor led C. to think that she was mad at her: she felt overwhelmed by this situation to the point of not wanting to go to school anymore and of developing a growing hatred attitude towards studying.

The environment was very tense: she never received gratification, nor a second chance after a bad grade. Even if done with the best intentions, this perpetuated situation made C. slowly loose interest in studying and distance herself from the school in general. Even if C. never took part in nor was a target of the vexations of the schoolmates, she developed a sense of uneasiness at school as she could not perceive that environment as neither welcoming nor pleasant.

At the end of the three years of lower secondary school, the orientation educational consultancy held on the basis of a test and of a graphological analysis, indicated to C. a vocational path. Being already demotivated, C. decided to follow this indication, thinking that it would have required a lower level of commitment. Today, C. harshly blames this method of orientation: "When you read, clearly written, that you are only worth a vocational school, you set a line telling yourself that you can't go any further. Maybe it's true that a person needs to be down to earth, but at that age adults should motivate you".

C. attended 3 years in a vocational school to become beautician, where she generally succeeded, gaining great gratifications but, at the same time, totally lacking motivation. She was already in the second year when she realized that being a beautician wasn't really the job for her. She felt trapped in a path in which, despite the excellent performances, she could find no satisfaction and she started feeling terrified by the idea of having to be a beautician forever. Nevertheless, in order to have a qualification to be spent in the job market, following her mother's advice, C. decided to enroll also in the fourth year.

Overwhelmed by this sense of inadequacy in relation to her vocational path, at the end of the fourth year C. dropped out her studies thinking to find herself a job. Without a certification, though, she couldn't find anything, except for those beauty centers that she already hated by then.

She spent a year doing nothing, waking up in the morning just waiting for the evening to come in order to go out with friends.

During these years C. wasn't lonely, she had plenty of friends: her social life proceeded smoothly, between meetings with peers and partying. But during a summer day at the sea, C. realized that she was throwing away her life and that she wanted to take it get back in control, starting with the achievement of a high school diploma. As soon as she got back home, she enrolled in an evening school. She reached her goal and she succeeded in getting her diploma with honors, this year. It was a great satisfaction that she fought for tenaciously, thinking only about herself and about what she wanted to do and become. Despite the fatigue of facing busy days helping at home, studying and going to school in the evening, she remained focused on her goals.

Even if wasn't easy when dealing with some particularly demanding teachers, every hard moment was overcome thanks to the strong motivation that moved C. and her awareness of wanting to get to the end of the path.

Today C. is happy and satisfied with her choices and next year she will enroll at the University in a Marketing course. Her philosophy of life is going slowly, one goal at a time, always doing her best. Thanks also to the unconditional support of her family, today, the maturity that C. shows, offers some teachings: it is important for young people to learn how to listen to their ambitions, to understand what they want to become without letting themselves be conditioned; as adults, we must leave them the possibility to make mistakes and we must acknowledge their right to "a second chance". 


\section{Life history 21. Denis \\ Title: Re-ignite motivation to study thanks to sport \\ Profile: Young people who have returned to school or training after ESL or suspending Source: Life history interview conducted in Villafranca (Verona), Italy, June 15, 2017.}

Denis is 21 years old. He moved to Italy from Guinea Bissau when he was 8 years old to reach, together with his mum and sister, his dad, who had already emigrated. He has a sunny personality and from the story emerges a dynamic character but also a strong attitude to reflection. As the journey of life unfolds, this is what amazes the interviewer: his ability to "act on his own" through a great deal of introspection.

He attended primary school in his town, before moving to a school in the outskirts. Since the lower secondary school, even if he met very motivated teachers, his academic achievements were unstable, with better marks in literature - his favourite subject. Despite his inclination and desire to nurture his passion for psychology, teachers, at the end of lower secondary school, addressed D. to a technical institute, without paying attention to what he wanted to do. Hence, D. enrolled on a technical institute, thanks to the good presentation done by the institute itself.

The educational path during upper secondary school was difficult from the beginning: all promises done by the teachers were broken and D's disinterest in the school's proposals rose day by day. Even his relationship with the professors was not positive, resulting in a D's lack of interests both in the work execution and in his own selfconfidence.

Although he failed the first year, he decided to continue, but he failed again the third year. Facing this new scholar failure, he decided to change school to see if thing could get any better and enrolled in accounting school. But the change didn't help him to overcome his difficulties. In addition to the difficulties with his professors and the lack of interest, the integration of foreign languages - that he had never studied before - made his educational path even harder. After the third failure, D. decided to get himself a job and to keep studying in an evening school. Again, D.'s choice was to study accounting, but only because it was the closest school to home and not because of a real interest in the subjects. At that time, he used to work as warehouse worker and as salesperson in a shop and those days were not happy: he used to work from 7 a.m. to 6 p.m. and then to go to school until 11 p.m. Despite D's difficulties, he eventually succeeded the third year. The following year, though, one of his siblings arrived from Africa with serious illness issues and he decided to definitively quit school because of this complicated family situation.

D.'s family did not support him during his studies: his dad was very inflexible, his mother tried to support him a little bit more but she was very busy taking care of the family, and his elder sister did not help him during his hardest times. D. faced by himself all the troubles and the thousands doubts that raised during his scholar path: his interest for psychology remained, but his self-esteem and the will to fight for his own ambitions fainted away as his desire for studying decreased.

A few later, D. decided to change sport: football, which he so much loved, did not offer him an environment where he could be approved and appreciated apart from his sporting qualities. D. started training in athletics, where he found amazing satisfactions, but most of all a group of friends who accepted him for what he was inside and outside the athletic team. Those friends opened his eyes, making him find the motivation to get back in school, pushing him to find something to motivate himself and to firmly believe in his abilities. The athletics environment represented a big change in his life, but a serious injury forced D to stop his competitions. Nevertheless, he kept being involved and he now volunteers in helping coaches with kids. The training ground helped him finding again his self-esteem, thinking about his objectives and, since he now dreams of becoming a sport psychologist, it also helped him collecting experiences in the related working field.

Today D. is more confident and determined. He went back to school and enrolled in the fourth grade of his evening school, organizing his job duties as a part-time work, in order to have time to study and get a diploma as soon as possible and reach his own goal. Sometimes he does not feel at ease with his friends who are finishing their studies at university, but he wants to show himself that everyone has his own path to walk, maybe with different timings, but what is important is to "become a man", without letting yourself give up. 
He looks back with some disappointment and would like a school able to value every student, observing everyone's abilities, a school that knows how to offer motivated and motivating professors, keeping attention to young people's interests and guiding them through difficult decisions, as the one they have to make at 13 years old.

\section{Life history 22. Mariana}

Title of the life history: Returning to school for practice

Profile: Young people who have returned to school or training after ESL or suspending

Source: Life history interview conducted in Amadora, Portugal, 2.06.2017

Mariana is 17 years old, was born in Portugal and lives in Amadora. During the interview she assumes a more timid attitude, which contrasts with the description she makes of herself in class: "very talkative".

After an academic year away from school - when the decision of drop out seemed inevitable - she returned to attend the current 7th year of a pastry/bakery vocational course. A course she confesses she likes very much and which responded to what she most wanted: "I have a great passion for cooking."

Until entering the 1st cycle in a school in Caneças, where she lived at that time, she was given to a nurse, a lady who lived in the same building and was taking care of other children. She goes to school and everything goes smoothly, although she recognizes that she has always been a "talking child" in class. In the 2nd cycle, she moves to a school at Ramada, integrates well into the new school and successfully completes the 2 nd cycle of basic education.

Her school path breaks down when she starts the 3 rd cycle. The first repetition comes in the 7 th year, in a secondary school in Odivelas. Almost all the classmates of the 2 nd cycle went to another school. But Mariana did not have a place in this school and is placed in a class "only for repeaters, older". She did not like the class and could not keep up with the schedules: "I had to get up earlier, get on the bus earlier."

This weak disposition for school happens in the same period in which she experiences a striking episode in her personal life: the divorce of the parents. Changing routines and the fragile economic condition of the mother impose difficult choices on her, such as deciding who to live with. Mariana describes this phase of her life as "complicated."

"I had to decide who I was going to stay with. It cost me because I wanted to stay with my mother, but then I felt sorry for my father. (...) Then sometimes my father would not talk to me and then I would lose some morale. (...) He sometimes is like that; he sometimes does not talk to me. (...) Because when he gets a girlfriend he forgets that he has a daughter."

These family events strongly influence school routines. At school level, absenteeism increased and the desire to go to school disappeared. Again, she repeated a second time in the 7th year. This year, she continued to miss classes and began to accompany her mother to her job at the catering company: "I would rather make money than go to school. I preferred to earn my money to buy my things because my father would not give me anything and my mother almost could not. So I always had to work to buy my things. I would rather do it than go to school."

Her mother did not offer much resistance regarding her dropping out of school. On the school side, Mariana also never felt concern about its situation. They never talked to her about the faults, according to her: "The teachers did not want to know either. They were just there to teach." In the 3rd period, when she already knew that she was reproved for excessive absences, she completely left school. "I was already repeating; I was not going to do anything there."

In the summer she went to Germany (where her older sister lives and works) and when she returned she tried to enrol in a vocational course, but they had no vacancies and directed her to go to regular school. "And they put me in 7th grade again. And I said: I will not go back to 7th grade because I know I will be stuck. I wanted to do a course soon (...) I went there to sign up and they did not look for anything. They did not even touch the registration." She does not go to the first day of classes and remembers well the decision: "I will not! Then they were people much younger than me. I would not feel good anymore and that's when I really demotivated." She sought work in a multinational company linked to catering, but low schooling prevented this possibility. She then decided to return to Germany to find a job opportunity. However, at the end of six months not only she did not find work in Germany, but she also found it difficult to learn the German language. 
After returning to Portugal, her mother enrols her in the school she currently attends in the bakery/pastry vocational course, an area she has always liked and has been successful in.

Currently Mariana lives with her mother, just the two. The older sister, aged 24, completed her 9th year of schooling and emigrated to Germany. Mariana's mother is 43 years old, works in a catering company and studied until the 6th grade. The father is the same age, studied until the 6th year of schooling and works as a construction foreman. There is no record in the nearest or extended family of someone who has reached higher education. The parents have never been very focused on school and have also never raised much expectation regarding the schooling of their daughters. Although her mother has never expressed a desire for her to continue studying, Mariana acknowledges that her mother is very proud of the success she has had in the current course and adds: "My mother liked me to take the cooking course."

Since 2014 Mariana has been dating with a boy seven years older, which according to her has had a very positive influence on her school path: "He's the one that changed me, he's encouraged me to study. (...) Tell me to study, to have a better life and then to build our life together." The boyfriend is currently working in Switzerland and has completed his 12 th year of schooling.

Beyond to her boyfriend, her network of sociability is restricted, composed of a best friend and neighbour who does not currently study or work, and two friends of the course with whom she shares interests and goals.

Mariana wants to complete the vocational course and emigrate to Switzerland to join her boyfriend. To finish the course with double certification - completing the 9th year of schooling and ending up as a pastry chef - of the current course is an asset for her. In the future she imagines herself working as a cook/pastry chef in a restaurant or hotel. According to Mariana, a school can be more attractive and motivating if it focuses more on study visits and the organization of events outside of school, which allow students to show what they do best. "We only did it twice at school and it went really well. We had a breakfast, we took two days off from our vacation, and we came here and did it on the open day of school. (...) Then they called us and congratulated us. Our class has such a bad reputation and then it highlights well in practice."

\section{Life history 23. Ciprian}

Title: Firefighter

Profile: Young people who have returned to school or training after ESL or suspending Source: Life history interview conducted in Bucharest, Romania, 19.07.2017

Ciprian is a 15-year-old teenager and is currently attending the fifth grade at Second Chance program in a school in Bucharest. He enjoys coming to classes and is also taking part in an educational program of a nongovernmental organisation. He is attending this program every day after school classes and finds the atmosphere and support for homework very useful and motivational.

During his leisure time, Ciprian plays football with his friends living on the same street as him. Moreover, he is often taking care of his younger brother - they go together in parks, and play outside.

Ciprian lives with his parents and with his sister and brother. His parents never went to school and never learnt how to read or write. Therefore, they cannot help Ciprian with his homework for school; his cousins, on the other hand, are studying in high school and are offering their support with studying.

His school path began at 7 years old when he enrolled in the first grade but was soon interrupted - Ciprian left school only two years later. The reason for leaving school was that he did not understand "anything from what the teacher was telling us - thus, I was not able to learn anything and decided to quit".

Years later, at the age of thirteen, at the pressure of his parents and his friends, Ciprian was convinced to come back to school. He says that he realized that only having a good education will help him succeed and achieve his goals in life. 
Ciprian recognizes the high importance that school has for him says because he wants to become "someone in life", to have a family and a good career. He has a clear goal in his mind, a goal he set at the very age of five - back then, he decided to become a firefighter when he grows up because his wish is to save people.

Helping others is something he started in the summer of 2017 when he offered his support as a volunteer for a summer kindergarten belonging to the same educational program he is receiving support from. Every day, he went to the kindergarten and helped the educator with the recreational activities for the small children. He became one of the most dedicated and appreciated volunteers.

Ciprian claims that children should be encouraged and helped by their family to achieve great things in life. When asked to imagine how he would convince a small child to go to school, Ciprian answered, "I would tell him that if wants to become someone in life, he should learn hard, listen to adults, pay attention to teachers, be responsible and respect his parents".

In his opinion, teachers should be calm and nice with the pupils in order to attract them to come to school. Children may be affected by the problems they are facing home and might not be able to learn at a fast pace like other kids. Therefore, all children need care and attention in order to perform well in school.

\section{Life history 24. Felix}

\section{Title: Everybody's friend}

Profile: Young people who have returned to school or training after ESL or suspending

Source: Life history interview conducted in Bucharest, Romania, 30.05.2017.

Felix is 13 and from the first encounter one can tell he is very sociable and pleasant to be around. He himself states that he enjoys being surrounded by nice people and getting along with those around him - his classmates, his teachers, his family and his friends.

Felix is currently in the third grade of the Second Chance program in a school placed near the main railway station in Bucharest. In his leisure time he practices kickboxing from which he developed self-discipline, respect for work and other people.

He is making friends with most of the people he is interacting with and this is one of the reasons he enjoys going to school and spending time around other teenagers. He is easily recognized as a leader among them as he establishes an environment of friendship, comfort and nonviolence among the other pupils. He has the utmost appreciation for one of his teachers, a lady who dedicates her energy and knowledge every day to her pupils.

Felix returned to school after four years of absence - he enrolled at 7 years old and attended school for only two years. He left school for spending time at home and taking care of his mother who suffered from mental illness. His father had died and he was the only one left to fulfil this role. His mother had a terrible relation with her brother and his family; her mental issues even caused an episode of conflict between the two when she came close to stabbing Felix's uncle.

His mother's behaviour made Felix wish every day he was living with his uncle and his cousins. He made a decisive step at the age of 11 when he ran away from home to his uncle's house, in another neighbourhood of Bucharest. Following this episode, his uncle got in touch with the authorities who gave him full custody of his nephew.

Up to this day, Felix lives with his uncle, his aunt and his cousins and feels happy and relieved to have a normal home, away from his mother's problems.

The fact that he had left school at the age of 9 makes him even more ambitious now that he returned. He likes coming to school every day and is working hard to stay in school and learn for the future. He has many friends who left school early - they live in a neighbourhood with a high criminal rate, where youngsters are involved in illegal activities and either never go to school or drop out at some point.

"Those people who do not go to school today will regret it in the future. I believe we can convince them to come to school through our own example; I know someone who enrolled in school for the first time when he was 20 years old, so it's never too late to start learning". 
He believes that peers or other people around us can have a good influence on our decision - in his case it was his kickboxing coach who convinced him to come back to school.

As for the future, Felix's dream is to become a policeman; he wants to be in the service of other people, to help those in need and fight for justice. He is decided to be a good policeman and has a very clear path in mind - he will graduate from high school and then enrol in the police academy. At the same time, his wish is to have a family and a home and maintain the beautiful relationship he has with his uncle, aunt and cousins.

Felix is a big supporter of education in all its forms, claiming that an educated person is polite and pleasant to be around and this is essential for making friends and having good relations with the rest of the people.

\section{Young people enrolled in education or vocational training}

Life history 25. Samuel (France)

Life history 26. Rachid (France)

Life history 27. Tommaso (Italy)

Life history 28. Inês (Portugal)

Life history 29. Ioana (Romania)

The last group of youngsters share an apparent condition of "normality". With the exception of Rachid (France), who is included in this group because of the strong resilience and the fact that he has always remained in school despite strong constraints (despite the absence of structural and family support), all other cases allow us to observe the influence of the structures operating by the positive. Rachid "expresses a certain pride to have pursued his school route in spite of the multiple difficulties. According to him, the teaching personnel predicted him a dark future by saying to him that he was going to end in prison".

The remaining group of young people attended school accompanied by a special mobilization of their families, who invested in their schooling and developed strategies that favored a long schooling path. It is about a daily life focused on school and its demands, and an organized family context, in its times and spaces, controlled and supported.

In the case of Samuel (France), the cultural and socio-economic resources of the family, the stability and confidence that they confer on their life, are clear. Despite his father's absence, and the changes he faces in his life, Samuel has a lot of support and guidance from a mother who knows how to say: "it's nothing. Do not worry, it will be better next time" when something goes wrong. He has the resources to adapt very quickly and successfully, and he thinks this happens every time because "when we are young, we adapt ourselves faster". 
He recognizes the quality of his school, and describes the relationship with his teachers as "parental". Samuel doesn't worry about his professional future because he is a brilliant pupil. He thinks that a good professor must be able to recognize the signs of disengaging and intervene in time. He recommends to the teachers to know the level of the pupils, to adapt themselves to the pupils, to be attuned. He always had good teachers around him.

With regard to Tommaso (Italy), a young man with a physical disability, both school and family have created a strong and permanent network around him, allowing him to develop his full potential. He counted from very early with multiple supports, "has been helped both at home and at school by specialised staff". He did not like it when he was forced to work alone, "out of the class, away from his companions", which made him feel different and irritated him very much". In another crisis situation, in the face of the tragic loss of a teacher, he had the support of the teachers and the deputy headmaster, who were all very attentive to help the students to reelaborate the event. In his path, he made the school choices as someone who knows himself very well, as someone who recognizes his best abilities. This strong network that surrounds him will allow him to become an agent of action and change in the world as he dreams to be. Tommaso faces no boundaries.

Inês (Portugal), for her part, faced difficulties in the schooling process, but took hold in the external network she was creating: a school inclusion project through music, the local church, the choir, and an attentive and available family, despite low school qualifications: "My parents always followed my school path very much. A lot I know is through my parents". The mother said repeatedly: "study, because tomorrow you will need your studies".

She had a happy basic education, she knows she was privileged. As stated, her memory is of "learning by playing", in opposition to what she considers to be a lot happening in schools today: "learning through offense. Learning through breaking people down. (...) I now see my brother with lots of stress to do homework". She also had the opportunity to experiment and reverse a vocational choice without too much pressure. When she wished to change from general education to musical education, the mother supported her and said: "Be happy. You have to be happy, isn't it?". In the dilemmas and difficulties she faced, she relied on her extended network. She asked, questioned, listened to others. She was not alone.

Even with fragile social conditions, it has been possible to sustain a positive schooling through a wide network of resources and experiences that have raised aspirations for social mobility and 
contributed to regulate and guide the individual effort of Inês. These processes happened in school, through school projects and teacher initiatives that rebuilt school sense; and/or in the network of sociabilities that monitored and guided her path in decisive moments. Inês believes that "education should be the highest national priority". And knows that, as the musician that she wants to became, she will be a learner for life.

Ioana (Romania) once again reveals that for a youngster to become the best version of himself, in order for him to be a good student, he needs a lot of outside support - stability, additional explanations, support in understanding subjects, family help. The list she makes for family support is long: "financial and moral support, from paying for her writing materials, books, private lessons, uniforms, etc. to giving her encouragement, love and affection. For Ioana it was also important to take advantage of different, motivating opportunities, such as young volunteering, which helped her "become more confident, to develop many skills and realize I have so many qualities I didn't even imagine having."

She also claims that "it's very hard to have good results at school without additional help". She blames the educational system for many problems - "school system is totally absurd from many points of view. Some teachers are not well prepared, not able to answer our questions and especially in high school, when you feel if a teacher is unprepared. The curriculum is heavy and exhausting, I will certainly not use many of the things I had to learn. Everything is very theoretical and not at all practical, very competitive. The relationship between teacher and pupil could also be improved. Overall, the teaching system should be renewed, more interactive and adapted to the new technology".

In fact, these young people show us that it is through the convergent effect of family, school and community that the processes of schooling and personal development take place. When one of these elements fails, becomes unbalanced, does not fulfil its role, the rest gets into trouble. The school has an absolute centrality in the way the youngster sees and represents himself. Bad results in school weaken young people. In this imbalance, when school fails, the youngster himself enters into effort, demotivation and renunciation. Therefore, strategies and actions are needed to monitor this cumulative effect, and to permanently rebalance this link, placing young people at the centre of their action.

\section{Life history 25. Samuel}


Title of the life history: A model student

Profile: Young people enrolled in education or vocational training

Source: Life story interview conducted in Paris, France, July 18 2017

Samuel, 19 years old, is the last child of a family of 5 children (the elder one is the only girl). He lost his father when he was younger, in 2009, and does not keep a lot of memories of him. He was a journalist and a General Secretary of the labor union of the professionals of the information and communication. Her mother is a senior executive and works in a ministry as in charge of an IT cell. His elder brothers are all engineers in the field of the computing. His older sister is consultant and Ph.D in sociology. He grew up in a wealthy family he always has all he needs since his childhood. Her mother always supported him in his studies even if she always left him the freedom to choose what he wants. He tells to attend non-specialized class which help him appropriate knowledge. Samuel doesn't worry about his professional future because he is a brilliant pupil and thinks that his success is due to the education given by her mother, who encouraged him. When his notes were less good, she told him: " it's nothing. Do not worry, it will be better next time ". He is native of Africa where he had begun his studies before arriving in France in 2015. He has a positive representation of the school which he perceives as the most classic way to succeed in a professional life. He continues his studies currently in a preparatory school named "Louis le Grand" and wants to reach the level of Master's degree to have the engineering degree in computing, as his older brothers and work at Google. The fact of being in a "high-end" school, represents an additional motivation to him who had his High school diploma in sciences with the highest distinction. In his school "Louis le Grand", there is an implicit competition with other students ("each one wants to be better than the other, even if we do not say it "). His best friend studied Physics and has no close friend who drop out his studies.

Samuel was always in "good schools" with pupils and professors who motivated him. He changed school and countries repeatedly but sees it as an additional wealth. He says to have adapted well every time because "when we are young, we adapt ourselves faster". He knew very young what he wanted to do later and very early got acquainted with the computing tools, the video games which fascinate him and, according to him, " boost the cognitive capacities ". Samuel says to have undergone the influence of his brothers to turn to the computing. He later wishes to educate his children by leaving them a big freedom, by avoiding limiting their use of computer even if he intends to control a little what they will do. For him, the fact of having been, from the bottom age registers in good schools by his parents, to have been raised in good conditions and to have parents who support him, favoured his success at school: "The parents and the frame in which we evolve play an important role in the education". Samuel has an idea on the causes of the early school leaving which according to him are connected to the living conditions, at the level of the pupil, the early marriage for certain girls, a bad orientation. He thinks that it would be necessary, for potential leavers, to propose less long, adapted courses, with less theoretical teachings. For them, it would be necessary to identify the causes very early to find a solution, to bring to them support. He thinks that a good professor must be able to recognize the signs of unhooking and intervene in time. He recommends to the teachers to know the level of the pupils, to adapt themselves to the pupils, to be attuned and to favour the emulation of the ideas. They have to make the pupils love school, like what they are doing in "Louis le Grand". For him, there are professors who teach, not for the pupils but to finish their program but says to have met it very rarely in his life. He sees certain closeness with his professors and considers their relations as "parental". Even if he is a brilliant pupil, he had punishments for gossip or incorrect behaviour. He thinks that punishments change nothing to a pupil behaviour but are sometimes necessary to give responsibilities to youngsters. He'd never thought to drop out ("it was not even an option"). 
Samuel's hobbies are to go to sport to relax. He does not have any other real activities his studies which are completely financed by an excellent grant he obtained from his country's government. The weekends, he sometimes goes out with buddies, to plays basketball...

\section{Life history 26. Rachid}

Title: A fighter

Profile: Young people enrolled in education or vocational training

Source: Life story interview conducted in Paris, France, July $21^{\text {th }} 2017$

Rachid had a very difficult school path but was brave enough not to stop his studies. He is 19 years old and partially grew in the 93 district. He arrived in France in 2005 but left for Italy afterward. He returned in France in 2010 and followed during one year a language training where, according to him, he learnt only to say " it is a chair, it is a table " while he would have been able, according to him, to learn that he is in the classic school. By going out of this training, he did not know how to either read or write. He afterward integrated a school into 2nd year of primary school which he doubles before succeeding 2nd year with "good grades". To the primary school, Rachid says to have had a normal route. To the middle school, it was more complicated because he was dismissed after one year at 6th degree with charges (activation fire alarm, disturbances). According to him, even if he made "stupid things", he was not guilty of what we blamed him. He changed by integrating a 5th grade into Bondy where " it was the law of the strongest. Weak ones were assaulted. I could not stay in my nice quiet spot. We picked me up(came to find me) and every time I was obliged to fight. There were also thefts of telephone a victim of which I was once but as I knew the authors he had returned it to me further to the intervention of the director. As I had denounced the culprits, I had received threats. I had to leave this school by fear of reprisals ". Rachid then made a DIMA which is normally for the pupils of 3rd and he discovered several jobs before integrating a professional high school into Bobigny, the "worse experience" of his life because of a professor " who decreased me" he says. Rachid often tells to regret having met this professor who offended him regularly instead of listening to him, or advising him and exchanging with him. However, he expresses a certain pride to have pursued his school route in spite of the multiple difficulties. According to him, the teaching personnel predicted him a dark future by saying to him that he was going to end in prison...

\section{Life history 27. Tommaso}

\section{Title: Beyond your limits}

Profile: Young people enrolled in education or vocational training

Source: Life history interview conducted in Italy, 31 ${ }^{\text {st }}$ May 2017

Tommaso, a 19-year-old, has been deaf since birth and confidently wears his hearing aids. His disability was discovered at a very young age, since, having a sister, seven years older than him, also affected by deafness, doctors carried out tests on him shortly after his birth and quickly found his problem. Since playschool, he has been helped both at home and at school by specialised staff and has dedicated a lot of time to speech language pathology sessions at home. All of this has allowed him to greatly improve his speech, so much that he starts his story easily and fluidly. His family has always been very supportive; his mum who is employed in a company, after having requested less working hours, practically dedicates all her free time looking after him and his sister at home, taking them to doctor's check-ups, requesting and monitoring educational and health support both at home and at school etc. His older sister has shared the disability with him, they have mutually supported and helped each other in facing the small and bigger everyday difficulties. Their father has always been very busy as a mechanic in a workshop, with 
perhaps a slightly surly character, but he has never let Tommaso, or his sister go without the support and encouragement in facing the challenges that awaited them in every stage of their lives. Tommaso always had a positive relationship with the special needs teachers in primary school, except for when they decided to make him work alone, out of the class, "away from his companions", which made him feel different and irritated him very much. During the third year of primary school, Tommaso, like many boys of his age, began to play football. He really enjoyed it, especially because it allowed him to "be with his peers". During primary school he had a very close friendship with an adopted boy from his town of foreign origin, with whom he spent entire afternoons. However, at the end of the middle school, they chose two different secondary schools and subsequently lost touch with each other. At the same time, Tommaso assiduously attended the oratory of his town, which allowed him to take part in different activities and experiences with other children of his age: trips, camps, parties, etc.

His schooling during middle school was very serene with both his teachers and classmates and the outcome of the final exam was, as expected, positive. The support at school and the speech language pathology at home has paid off and now Tommaso speaks correctly and confidently.

Having been interested since he was very young in manual activities, DIY, gardening and small jobs in the house, Tommaso chose to enrol in a secondary school with more hours in the laboratory and for this reason he has aimed at the technical school, in the electrotechnical department. Tommaso made this specific choice because electronics is a field in which you do not have to have good hearing. Furthermore, it meant going to a school that was a separate branch of a higher institute and therefore smaller, where the relationship the children and teachers maybe could have been more direct and even more human. After a quiet start to the school year, Tommaso experienced tremendous shock for the unexpected death in a road accident of his special needs teacher. He was a very prepared person in his work, with whom he had immediately established a very positive relationship. The impact of that tragic event influenced the entire class, despite the support of the teachers and the deputy headmaster, who were all very attentive to help them re-elaborate the event. Subsequently, another special needs teacher arrived who, according to Tommaso, did not engage in his work. This aggravated him very much and made him irritated both at school and at home.

From the third year of secondary school, Tommaso became passionate about music, thanks to classmate who played the guitar. Learning to "strum" he discovered a different way to listen to songs, he became a fan of rock music and finally, was able to express his feelings through music. At that time, he felt excluded from the class and society and music allowed him to find a space in which he felt accepted.

Fortunately, C., his current special needs teacher arrived that year. A special relationship was immediately created between them, based on mutual esteem and trust. Around him Tommaso "continued feeling" the positive presence of teachers and the deputy headmaster who believed in him, in his potential and this pushed him to study and give his best. Thanks to his commitment and the trust of the teachers around him, Tommaso has achieved excellent school results that today, just before his final exams, make him particularly proud of himself with many plans still to be fulfilled. One of them is to take part in a mission in Africa, to help the children living there. Tommaso says that "by helping others, you help yourself". Then he wants to design electrotechnical equipment that can meet the needs of people who are physically challenged. He also wishes to resume studying the guitar because music makes him truly feel himself and perhaps play in a group or become a songwriter, so he can express his emotions through words and music.

In sports, Tommaso wants to continue doing athletics (which he has recently discovered), especially the high jump, given the good results in recent competitions. Finally, the desire to travel, discover new places and new cultures, or to return to places already visited in childhood to change perspective, certainly using English, a language that enthuses him and connects him with foreigners, making him feel "less different", compared to how he feels speaking his native tongue. 


\section{Life history 28. Inês}

Title: I seek strength from the Orquestra Geração

Profile: Young people enrolled in education or vocational training

Source: Life history interview conducted in Amadora, Portugal, 26/05/2017.

Inês is 16 years old, was born in Portugal and lives in Amadora. Their parents are originally from São Tomé e Príncipe. She reveals a huge passion for music. A calling that was born early in a project related to percussion in kindergarten, went through participation in the choir of the school still in 5th grade, and culminated, for now, in the project Orquestra Geração, in which she is dedicated to a woodwind instrument: the trumpet. She describes herself as a person full of "whys".

Currently attending the 10th grade of the Lisbon Metropolitan Vocational School, she considers that it was a choice based on the quality of education and that allowed her to continue musical studies: "it's an education targeted to what we want. Most people who are in a regular course have a lot of prejudice, because it's very practical, very pragmatic, but it helps us do what we want". She had already attended the 10th grade in regular education in the humanities course. At that time, she wanted to be a psychologist and many other things; confesses that she was a "bit confused" and it was the special liking for music that led her to switch to the professional course more oriented towards this area.

She entered at the age of 4 to the kindergarten. Describes the 1st cycle as "very good" and a beginning of schooling striking and "very happy". She felt a lot of support from the teacher, with whom she still has contact, and recalls that she liked to go to school. Her memory is of "learning by playing", in opposition to what she considers to be a lot happening in schools today: "learning through offense. Learning through breaking people down. (...) I now see my brother with lots of stress to do homework. He has a lot of homework on a daily basis and the relationship with colleagues is totally different." In the change of school to the 2 nd cycle, she felt quite a few differences and lacked "that anchor", referring to the teacher of the 1st cycle. In terms of educational attainment, she loved mathematic and Portuguese, and in the 7 th grade discovered a fondness for history, which still holds.

It was in the 8th grade that she failed in math, which until then had never been a problem. "I started to give up." Inês relates this event to a phase in which her "mentality changed" through more "seriously" readings that made her grow, events in her family life, school and the entry into the Orquestra Geração. A period of greater social awareness and reflexivity in relation to the world that surrounds her: "there is poverty, poorly distributed wealth. There are many things that go on around us and we are navel-gazing and nothing else. I saw that I wanted to grow up, to evolve and be someone else, but then I hid in a corner and saw one to make fun of the other, to beat each other...". She shares that she suffered bullying and how these events marked her: "I have already suffered bullying in my 7 th grade with a group in class. For instance, they insulted me. They mocked my parents because I live in the social neighbourhood X. Of course I'm not proud to say that I live in that place, but people's problem is to judge by the place where someone lives, by the way someone dresses and not by the way someone thinks". She also says that the 7th grade class had many repeaters and "repeaters in that school are chaos". She considers that her attitude of responding and reacting helped her to limit those events to that school year. The Orquestra Geração helped her to overcome and find a kind of "refuge", because "at the end of the day I went to the Orquestra and it was there that I studied, read, talked, walked around and that was how I got distracted. (...) Teachers have not yet realized the impact the Orquestra has on people's lives."

In the 9th grade she recovers the school results and says that she felt "more strength". Somehow the family situations were solved and Inês found the stability to study. When a teacher proposed psychological counselling at school, she replied: "my psychologist is the Orquestra Geração, literally."

In secondary education she enters the humanities course at a secondary school. She lived a school year full of doubts about moving to a music course. She spoke with a teacher, with colleagues and her parents. If the father was not 
very happy with her having to go back one year, the mother supported her and said: "Be happy. You have to be happy, isn't it?"

Inês lives with her parents, her maternal grandmother and two brothers - she is the middle sister. The eldest brother is 26 years old and finished high school in the course of information technologies, with a school path marked by failures. He recently started working in a supermarket because he didn't find a job in his training area. The younger brother is 7 years old and attends the 2nd grade of schooling. The mother was born in São Tomé, the second oldest of eight siblings, and never attended school. In Portugal she learned to read alone and with the help of her children. She currently works as a cleaning lady in an office and in a private house. The father is a garbage collector, works in a Municipal Council and to increase the family income punctually also does other works. He was always the tutor and he was attending school meetings. But when he couldn't go to school, the mother assumed this responsibility: "My parents always followed my school path very much. A lot I know is through my parents." The mother said repeatedly: "study, because tomorrow you will need your studies".

She's linked to the youth group of the church and the area of residence, and belongs to a catholic community, in which she sings in the choir. Currently attending the professional music course in Lisbon, she doesn't give up the Orquestra Geração, and every Saturday she rehearses, performs shows or stages. The Orquestra allowed her to make friends over the years and travel abroad. All her friends of the Orquestra want to pursue studies for higher education. She doesn't have friends who have dropped out of school, but she knows who has given up gradually. She considers that these "had no one to motivate them... it takes someone who knows our limits, our weaknesses. People give up because of that, too, because they don't have anyone."

With respect to the future she imagines no other path than to study music in higher education. She wants to enter the Superior School of Music and Arts of the Spectacle (ESMAE), in Porto. In Inês' opinion: "A musician is always studying". After finishing higher education, she wants to work in Portugal because she doesn't imagine herself far from the family. She would love to work in an Orquestra and "first make my parents proud and show them that it was worth going back one year."

She thinks that it is fundamental to further develop the arts' area and to hold young people to do what they like in their country. She stresses the importance of these sociological studies on school failure and drop-out and the need of society not "looking away" when the subject doesn't directly concern it. The need of trying to understand why this happens and why "there are more and more children who do not want to study". She adds that more support is needed for schools and a greater interest of the teachers by the students. Inês recalls what she has heard many times: "«I don't want to know if you are learning or not. I earn anyway at the end of the month» I've heard it so many times. «You can continue to do this, but I earn mine at the end of the month» Or, «Teacher, I don't understand»«Listen, you should. I explained once, I won't explain twice» And the students are giving up, they are giving up." Inês believes that education should be the highest national priority and that students shouldn't give up.

\section{Life history 29. Ioana \\ Title: The path to success \\ Profile: Young people enrolled in education or vocational training Source: Life history interview conducted in Bucharest, Romania, 18.07.2017}

Ioana is a 19-year-old girl graduating from a vocational high school and after studying visual arts for four years she entered the University and is now studying architecture.

She has always been a student with the highest results from her class and a good daughter. She is very ambitious and has always worked hard to pass all of her exams in order to graduate high school and become a student. After graduating from the university, Ioana wants to work in the social field and develop art projects that would help the 
others, especially children from disadvantaged communities. As a matter of fact, for the last 3 years, Ioana has been volunteering in social projects and has been fully dedicated to this type of activities.

She comes from a family with 3 children so having 2 older brothers and her parents support her throughout her entire life helped and encouraged her to always pursue her dreams. Her parents graduated from high school and have had steady jobs ever since. They have always offered Ioana both financial and moral support, from paying for her writing materials, books, private lessons, uniforms, etc. to giving her encouragement, love and affection.

She admits that her educational path would have been a lot more difficult without the support of her parents. She claims that it's very hard to have good results at school without additional help. Apart from this, Ioana's parents never put pressure on her with house chores, so she could have enough time to learn for school.

Ioana admits that getting through school was really hard, because after spending almost the entire day at school between theoretical classes and practical workshops she also had to continue studying a lot at home. She blames the educational system for many problems - "I think the Romanian school system is totally absurd from many points of view. Some teachers are not well prepared, not able to answer our questions and especially in high school, when you feel if a teacher is unprepared. The curriculum is heavy and exhausting, I will certainly not use many of the things I had to learn. Everything is very theoretical and not at all practical, very competitive. The relationship between teacher and pupil could also be improved. Overall, the teaching system should be renewed, more interactive and adapted to the new technology".

Apart from that, having the time for extracurricular activities is almost impossible because there is very little time left after school tasks.

When asked about what can be done to prevent school dropout, Ioana claims that the government should develop programs for helping the parents, especially those living in rural areas so they could benefit from education, private counselling, financial help etc.

In her opinion, many parents don't have enough money, education and information and this are the main reasons for the early school leaving phenomenon. She says that children should also be aware of the advantages and the necessity of school and education because it is very hard to succeed in life without having these two.

Ioana states that it is vital for children's education to have the constant support of their family and from the system (government, teachers, other stakeholders), but also to be given the chance to be involved in other types of activities, like volunteering: "A major change in my life happened in the 10th grade when I became a volunteer in a NGO.

It helped me become more confident, to develop many skills and realize I have so many qualities I didn't even imagine having."

\subsection{Key findings on school failure and ESL from the perspective of adults and stakeholders}

As mentioned previously for young people, also adults and stakeholders were consulted through the use of qualitative tools, i.e. interviews and focus groups, and asked to identify the complex decisions, actions, attitudes, behaviour and views underlying ESL not only at individual level but also at family, school and community levels. Interviews were conducted and focus groups formed at national level by each participating country. The next sections proceed to the presentation and analysis of the information gathered through that activities and reported by 
the partner using the template. ${ }^{55}$ Factors explaining disengagement and ESL from the perspective of adults and stakeholders are shown in several tables.

\subsubsection{Factors leading to failure and ESL}

The profile of stakeholders covers a varied group of categories, as specified in chapter 2 . Therefore, the diversity of factors causing failure and ESL, according to stakeholders, stem from this underlying variety.

The factors listed by the stakeholders were, as in the group of youngsters, grouped in four categories: a) individual; b) family; c) school; d) and community. We will begin analysing individual factors.

Within the group of individual factors (see Table 4.6) emerged one set related to motivation and attitude, where boredom and having no pleasure at school, low or lack of motivation and lack of interest were identified in all territories.

\section{It is very important to give motivation to students through extra-school activities: external inputs are productive and have positive insights on school results too, where the risk of low self-esteem is spread. [vocational and training institution representative, Cuneo, Italy]}

More psychological and inner feelings of lack of self-esteem, self-confidence, lost confidence in own capacities, intolerance to frustration, were also described, especially in the interviews of Croatia, France and Italy (both territories).

Absenteeism is, also, a factor in the perspective of the stakeholders in France, Italy (Cuneo) and Portugal. In Italy (both territories), the lack of study, or studying too little, is also an important identified factor.

Aspects related to autonomy and responsibility also stemmed as individual factors described by stakeholders. These aspects are, for example, the early entry in the learning system (Portugal), not liking to be sitting in the classroom (PT and Italy), not being matured enough to work by themselves or to make projects in the medium and long term. In UK, this (lack of) autonomy and responsibility factor is described as the youngster not seeing a point going to school.

They use to miss classes to stay playing soccer. They like the school, what they do not like is to stay in the classrooms [Teacher, Portugal]

\footnotetext{
55 Although factors were identified, no quotes were present by the UK partner.
} 
Another set of individual factors are the ones related to responsibilities and financial constraints. As the ones described by youngsters, these concern having to work due to poverty or to help supporting the family. Only in Croatia and in France those kind of factors did not come out to explain ESL.

\begin{abstract}
We have students who have academic skills and who are oriented in BTS, it is called the school risk aversion, it is measured, doing long studies is taking risks ... how I will finance the studies ... it will serve me ... and as there is a lack of knowledge of the school system from their point of view it is risk taking ... they want to first have a job ... the social background does a lot of the trick [teacher, librarian, France]
\end{abstract}

Health problems are another origin of causes for failure and ESL, according to stakeholders from all partners' countries, except Romania that does not state any of these. Difficulties in learning or learning disabilities, lack of attention, psychological problems, and excessive time, or even addiction to technologies and social media (mentioned in France, Italy - both territories - and Portugal) were described by stakeholders.

We work with borderline guys. Sometimes families don't have instruments to face difficult situations, they don't know what to do, they experimented so many failed experiences. Parents should ask for help; school and social services should intercept these situations as soon as possible [Social worker, Villafranca (Verona), Italy]

Other individual factors are difficulties for students with migrant backgrounds, regarding local languages - described in Italy (Cuneo), France and Portugal - or regarding the integration and continuity when entering the new learning system - as exemplified in Portugal. Another examples, such as bad choices regarding friends, were indicated also in Portugal. In Romania emerged "working" and, in the UK, "living alone", as other individual factors as underlying causes for failure and leaving school.

Most of the cases were friendships, they always say: I used to hang out with bad company [Teacher, Portugal] 
Table 4.6 Individual factors explaining disengagement and ESL (Stakeholders)

\begin{tabular}{|c|c|c|}
\hline Individual factors & Individual factors in each country & Quotes from all partners \\
\hline \multirow[t]{6}{*}{$\begin{array}{l}\text { Motivation and } \\
\text { attitude }\end{array}$} & $\begin{array}{l}\text { HR } \\
\text { - boredom } \\
\text { - low motivation } \\
\text { - selective motivation among school subjects and } \\
\text { professors } \\
\text { - lack of self-confidence }\end{array}$ & \multirow{6}{*}{$\begin{array}{l}\text { Youngsters' dreams are not taken into } \\
\text { consideration, or they are 'forced' (by parents, by } \\
\text { the community,...): this could be so stressful for } \\
\text { students that they could decide to leave school. } \\
\text { [school counsellor, Cuneo, Italy] } \\
\text { It is very important to give motivation to students } \\
\text { through extra-school activities: external inputs are } \\
\text { productive and have positive insights on school } \\
\text { results too, where the risk of low self-esteem is } \\
\text { spread. [vocational and training institution } \\
\text { representative, Cuneo, Italy] }\end{array}$} \\
\hline & $\begin{array}{l}\text { FR } \\
\text { - boredom, no pleasure at school, no aims } \\
\text { - lack of motivation, studies got no meanings and } \\
\text { are considered useless } \\
\text { - lost confidence in their capacities, spiral of failure } \\
\text { - not motivated by the academic content and } \\
\text { academic pedagogy } \\
\text { - absenteeism } \\
\text { - intolerance to frustration } \\
\text { - aggressiveness, violence }\end{array}$ & \\
\hline & $\begin{array}{l}\text { IT } \\
\text { Cuneo } \\
\text { - low level of self-esteem } \\
\text { - no future perspective } \\
\text { - lack of a personal relationship with teachers and } \\
\text { other operators } \\
\text { - feeling of isolation } \\
\text { - absenteeism } \\
\text { - boredom } \\
\text { - low interest/willingness to study } \\
\text { - cultural deprivation and lack of cross-cutting } \\
\text { competencies } \\
\text { - "school phobia" } \\
\text { Villafranca (Verona) } \\
\text { - youngsters don't see any more the school as a } \\
\text { "social lift" } \\
\text { - students study very little } \\
\text { - low self-esteem and perception of low self- } \\
\text { effectiveness }\end{array}$ & \\
\hline & $\begin{array}{l}\text { PT } \\
\text { - demotivation regarding school } \\
\text { - lack of interest on classes } \\
\text { - irregular attendance and absenteeism } \\
\text { - lack of interest in tutorials } \\
\text { - obligation to attend courses that one does not like }\end{array}$ & \\
\hline & $\begin{array}{l}\text { RO } \\
\text { - boredom at school } \\
\text { - lack of motivation }\end{array}$ & \\
\hline & $\begin{array}{l}\text { UK } \\
\text { - behaviour issues } \\
\text { - pressure not to attend and do well from friends and } \\
\text { family } \\
\text { - lack of interest from pupil }\end{array}$ & \\
\hline \multirow{3}{*}{$\begin{array}{l}\text { Autonomy and } \\
\text { responsibility }\end{array}$} & HR & \multirow{3}{*}{$\begin{array}{l}\text { They use to miss classes to stay playing soccer. } \\
\text { They like the school, what they do not like is to stay } \\
\text { in the classrooms [Teacher, Portugal] }\end{array}$} \\
\hline & $\begin{array}{l}\text { FR } \\
\text { - not matured enough to work by themselves } \\
\text { - inability to make projects in the medium, long } \\
\text { term } \\
\text { - misunderstanding on school expectations } \\
\text { - misunderstanding in school missions }\end{array}$ & \\
\hline & $\begin{array}{l}\text { IT } \\
\text { Cuneo }\end{array}$ & \\
\hline
\end{tabular}




\begin{tabular}{|c|c|c|}
\hline & $\begin{array}{l}\text { - incapacity of facing difficulties and high level of } \\
\text { competition at school/on the labour market } \\
\text { - difficulty staying/sitting in the classroom } \\
\text { Villafranca (Verona) }\end{array}$ & \\
\hline & $\begin{array}{l}\text { PT } \\
\text { - disliking to stay inside the classroom } \\
\text { - immaturity (early entry in the learning system) }\end{array}$ & \\
\hline & RO & \\
\hline & $\begin{array}{l}\text { UK } \\
\text { - see no point to go to school }\end{array}$ & \\
\hline \multirow{6}{*}{$\begin{array}{l}\text { Responsibilities and } \\
\text { financial constraints }\end{array}$} & HR & \multirow{6}{*}{$\begin{array}{l}\text { we have students who have academic skills and } \\
\text { who are oriented in BTS, it is called the school risk } \\
\text { aversion, it is measured, doing long studies is } \\
\text { taking risks ... how I will finance the studies ... it will } \\
\text { serve me... and as there is a lack of knowledge of } \\
\text { the school system from their point of view it is risk } \\
\text { taking ... they want to first have a job ... the social } \\
\text { background does a lot of the trick [teacher, } \\
\text { librarian, France] }\end{array}$} \\
\hline & FR & \\
\hline & $\begin{array}{l}\text { IT } \\
\text { Villafranca (Verona) } \\
\text { - need to work due to poverty }\end{array}$ & \\
\hline & $\begin{array}{l}\text { PT } \\
\text { - financial autonomy } \\
\text { - to help supporting the family }\end{array}$ & \\
\hline & $\begin{array}{l}\text { RO } \\
\text { - need to work }\end{array}$ & \\
\hline & $\begin{array}{l}\text { UK } \\
\text { - too many difficulties to get to school (money) } \\
\text { - need to work because household income is low } \\
\text { - need to support themselves }\end{array}$ & \\
\hline \multirow[t]{6}{*}{ Health } & $\begin{array}{l}\text { HR } \\
\text { - difficulties in learning } \\
\text { - lack of attention } \\
\text { - health problems }\end{array}$ & $\begin{array}{l}\text { The head teacher told me my child was } \\
\text { hyperactive. Then I decided to put him in another } \\
\text { school where he do a lot of sport and was anymore } \\
\text { seen like a different child with too high energy. } \\
\text { [family member, France] }\end{array}$ \\
\hline & $\begin{array}{l}\text { FR } \\
\text { - difficulties in learning } \\
\text { - lack of sleep } \\
\text { - psychological problems } \\
\text { - learning disabilities } \\
\text { - addictions (games, internet, especially social } \\
\text { media) }\end{array}$ & \multirow[t]{5}{*}{$\begin{array}{l}\text { We work with borderline guys. Sometimes families } \\
\text { don't have instruments to face difficult situations, } \\
\text { they don't know what to do, they experimented so } \\
\text { many failed experiences. Parents should ask for } \\
\text { help; school and social services should intercept } \\
\text { these situations as soon as possible [Social worker, } \\
\text { Verona, Italy] }\end{array}$} \\
\hline & $\begin{array}{l}\text { IT } \\
\text { Cuneo } \\
\text { - emotional difficulties and influence of the } \\
\text { sentimental sphere } \\
\text { - technological addiction (smartphones) } \\
\text { Villafranca (Verona) } \\
\text { - mental problems, crisis of panic and anxiety } \\
\text { - dependence of computers and social media } \\
\text { - drug use }\end{array}$ & \\
\hline & $\begin{array}{l}\text { PT } \\
\text { - difficulties regarding learning } \\
\text { - mental health problems } \\
\text { - excessive time spent with new technologies }\end{array}$ & \\
\hline & RO & \\
\hline & $\begin{array}{l}\text { UK } \\
\text { - health problems } \\
\text { - mental health problems }\end{array}$ & \\
\hline Others & $\begin{array}{l}\text { HR } \\
\text { - emigration }\end{array}$ & $\begin{array}{l}\text { They always enter in a higher level than what is our } \\
\text { requirements here. They don't know the subjects, }\end{array}$ \\
\hline
\end{tabular}




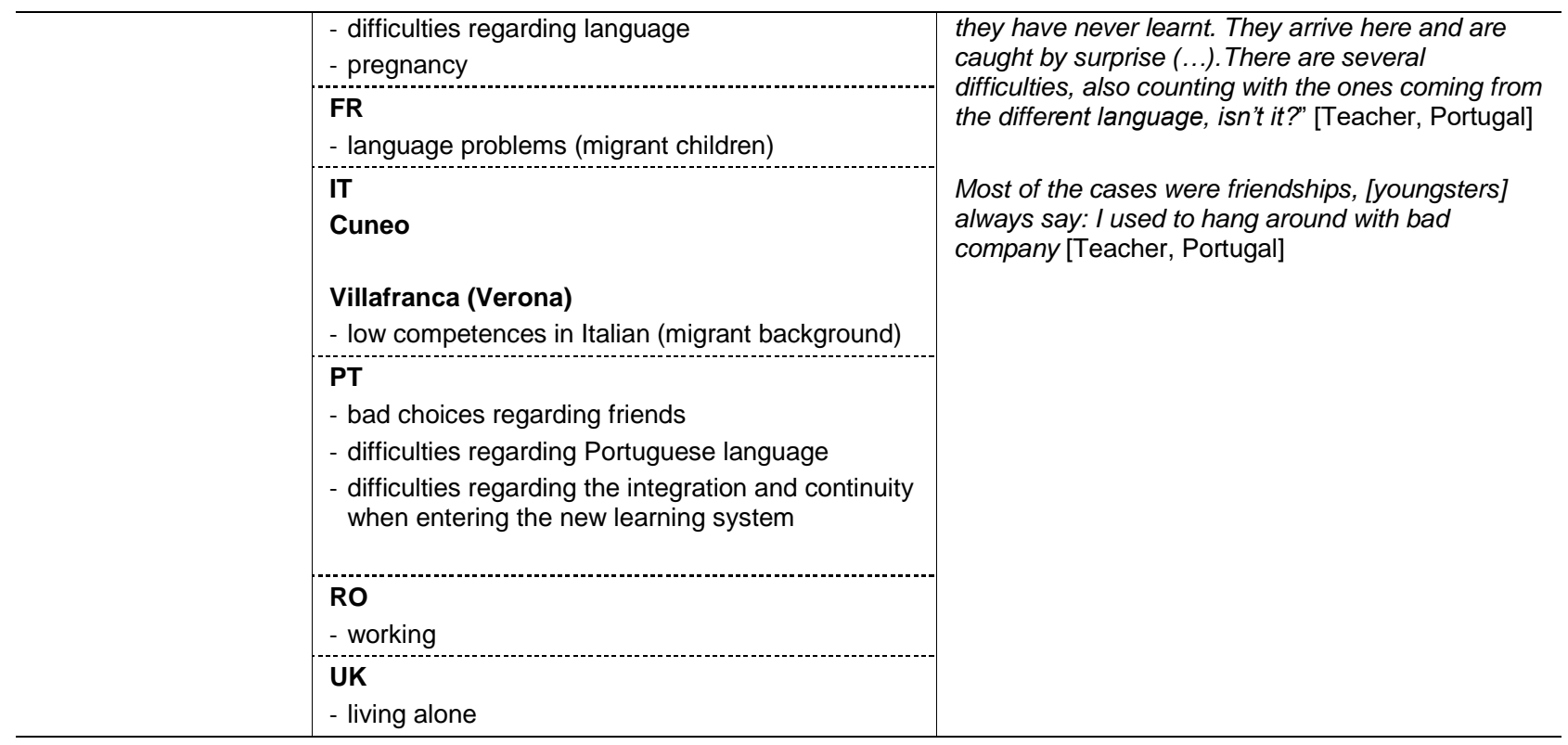

Some specific family factors were, as well as in the case of young participants, identified by stakeholders as triggers for failure and ESL. Categories of reasons such as resources, family structure, family relationships, and engagement with school and education (see Table 4.7) are under this family factors set.

A cross-country analysis in what concerns family resources reveals a homogenous pattern: unemployment, poverty, low living conditions, lack of financial capacity to support education expenses and other related needs, are dimensions of some scarce economic resources. Cultural resources are, also, listed problems; in the shape of low levels or lack of education or, in migrant background situations, low knowledge about school culture/system in the country of residence (examples in France or Italy, Cuneo).

Most of them come from a lower class were the unemployment is going on for a long time. One of the things the group of school does is this follow-up of the families in order to provide them some social answers. (...) In our case, the situations of absenteeism or early school leaving of most of kids are due to the economic situation of their family households. [Social worker, Portugal]

If parents in poor neighbourhoods are not helped, poor parents, well, if parents cannot help the children in their schooling, we see it on absences, children drop out [Teacher, France]

Family structures, such as single parent households on one hand (as identified by stakeholders in Croatia or France); and households overcrowded with extended or big families, on the other hand (like in France), carry some features that influence failure at school, like lack of family support or supervision, loneliness, among others.

Kids are left alone. The parents get home from work when they are already sleeping. Maybe the kid was upset with having dinner alone and starts behaving unmannerly. Or he says he went to school and did not. Or fell asleep and nobody noticed because he is alone, everyone left home 
already. This question of supervision seems very important to me: this of having someone who really cares, who really go to school to know about the good and the bad, someone who is alert. [Local government official, Portugal]

Family structure may even originate excessive caregiver responsibilities with relatives, as this factor was identified by adult participants in Italy-Cuneo, Portugal and the UK.

\begin{abstract}
I have pupils who arrive here in the morning with notes written by their parents asking for them to leave earlier in order to pick their younger siblings up from school. If the younger brother is ill, is the student who stays at home, it is not the mother who doesn't go to work. So, it's older siblings assuming the role of parents." [Teacher, Portugal]
\end{abstract}

Family relationships impact on students' records at school, therefore in ESL and failure. Divorces, separated parents or other family problems as violence and abuses are also present in the speeches of stakeholders that participated in the social survey. Only in Portugal or Romania were not noted.

Last in family factors is the category of reasons unfolding the kind of engagement families have with education and school, in general being absent in school environment and life of their children, due to low or misunderstanding expectations or importance regarding school, and that emerged in all European adult participation.

There are parents who didn't have a high level of education but who have children who succeed at school. There are also parents with high socio-economic status with children who failed at school. ESL is complicated and children don't always do what their parents want them to do. There is a gap between the parent's expectations and the children's. How can we do, to make children more implicated and to listen much better to their needs? Where is the child's desire? [Social association's responsible, France] 
Table 4.7 Family factors explaining disengagement and ESL (Stakeholders)

\begin{tabular}{|c|c|c|}
\hline Family factors & Family factors in each country & \multirow{6}{*}{ 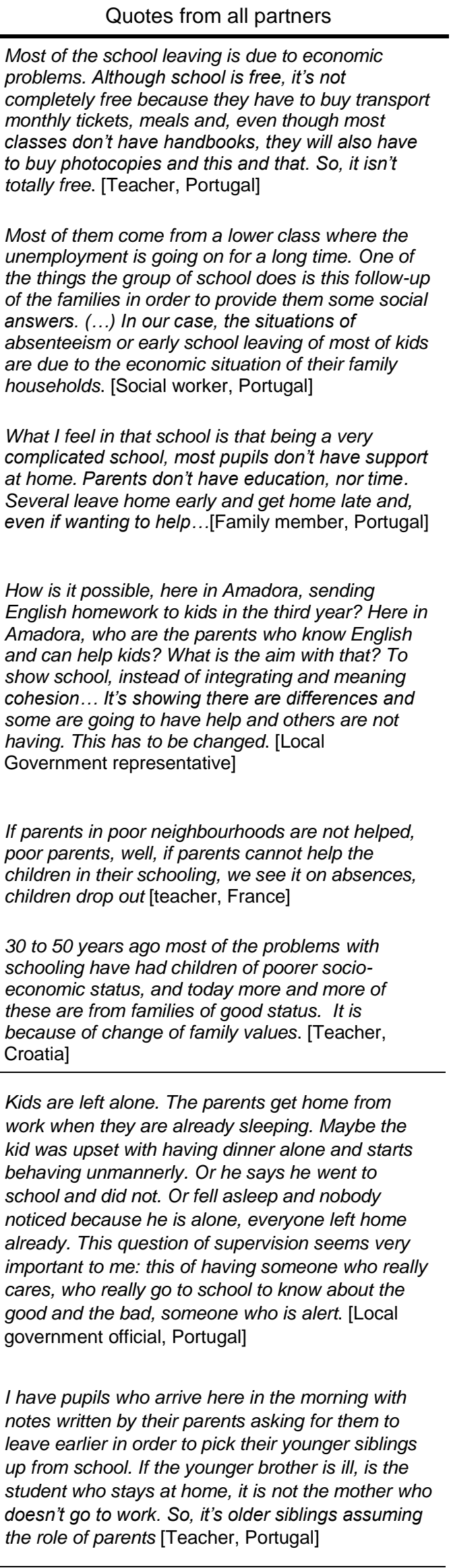 } \\
\hline \multirow[t]{7}{*}{ Resources } & $\begin{array}{l}\text { HR } \\
\text { - parent's unemployment } \\
\text { - incomplete and inadequate family values and } \\
\text { competences (skills) } \\
\text { - helplessness in parenting }\end{array}$ & \multirow{7}{*}{$\begin{array}{l}\text { Most of the school leaving is due to economic } \\
\text { problems. Although school is free, it's not } \\
\text { completely free because they have to buy transport } \\
\text { monthly tickets, meals and, even though most } \\
\text { classes don't have handbooks, they will also have } \\
\text { to buy photocopies and this and that. So, it isn't } \\
\text { totally free. [Teacher, Portugal] } \\
\text { Most of them come from a lower class where the } \\
\text { unemployment is going on for a long time. One of } \\
\text { the things the group of school does is this follow-up } \\
\text { of the families in order to provide them some social } \\
\text { answers. (..) In our case, the situations of } \\
\text { absenteeism or early school leaving of most of kids } \\
\text { are due to the economic situation of their family } \\
\text { households. [Social worker, Portugal] } \\
\text { What I feel in that school is that being a very } \\
\text { complicated school, most pupils don't have support } \\
\text { at home. Parents don't have education, nor time. } \\
\text { Several leave home early and get home late and, } \\
\text { even if wanting to help...[Family member, Portugal] } \\
\text { How is it possible, here in Amadora, sending } \\
\text { English homework to kids in the third year? Here in } \\
\text { Amadora, who are the parents who know English } \\
\text { and can help kids? What is the aim with that? To } \\
\text { show school, instead of integrating and meaning } \\
\text { cohesion... It's showing there are differences and } \\
\text { some are going to have help and others are not } \\
\text { having. This has to be changed. [Local } \\
\text { Government representative] } \\
\text { If parents in poor neighbourhoods are not helped, } \\
\text { poor parents, well, if parents cannot help the } \\
\text { children in their schooling, we see it on absences, } \\
\text { children drop out [teacher, France] } \\
30 \text { to } 50 \text { years ago most of the problems with } \\
\text { schooling have had children of poorer socio- } \\
\text { economic status, and today more and more of } \\
\text { these are from families of good status. It is } \\
\text { because of change of family values. [Teacher, } \\
\text { Croatia] }\end{array}$} \\
\hline & $\begin{array}{l}\text { FR } \\
\text { - amplitude of working hours, parents with two jobs } \\
\text { - ignorance of school culture in France }\end{array}$ & \\
\hline & $\begin{array}{l}\text { IT } \\
\text { Cuneo } \\
\text { - family's fragility } \\
\text { - poverty, unemployment, low living conditions } \\
\text { - lack of economic resources to keep up with after } \\
\text { school lessons, learning activities, etc. } \\
\text { - difficulties of foreign parents to understand the } \\
\text { Italian school system } \\
\text { - overload by job engagement } \\
\text { Villafranca (Verona) } \\
\text { - poverty } \\
\text { - parents' low level of education } \\
\text { - lack of knowledge in local languages to help } \\
\text { students }\end{array}$ & \\
\hline & $\begin{array}{l}\text { PT } \\
\text { - low skilled parents } \\
\text { - difficulties in keeping up with the children's school } \\
\text { activities } \\
\text { - lack of financial capacity to support education } \\
\text { expenses and other related needs } \\
\text { - single parent or extended families with financial } \\
\text { problems }\end{array}$ & \\
\hline & $\begin{array}{l}\text { - parents with no time to keep up with their } \\
\text { children's school activities (very demanding } \\
\text { schedules) }\end{array}$ & \\
\hline & $\begin{array}{l}\text { RO } \\
\text { - parents' lack of education }\end{array}$ & \\
\hline & UK & \\
\hline \multirow[t]{5}{*}{ Family structure } & $\begin{array}{l}\text { HR } \\
\text { - broken homes/single parenting }\end{array}$ & \\
\hline & $\begin{array}{l}\text { FR } \\
\text { - single parent family } \\
\text { - lack of family support } \\
\text { - no network or a not efficient network for education } \\
\text { - -bad living conditions (overcrowding flats) }\end{array}$ & \\
\hline & $\begin{array}{l}\text { IT } \\
\text { Cuneo } \\
\text { - need to help with housework or to look after } \\
\text { relatives }\end{array}$ & \\
\hline & $\begin{array}{l}\text { PT } \\
\text { - excess of responsibilities with the family (older } \\
\text { siblings having caregiver tasks) } \\
\text { - loneliness } \\
\text { - lack of parent supervision }\end{array}$ & \\
\hline & $\begin{array}{l}\text { RO } \\
\text { - parents working abroad }\end{array}$ & \\
\hline
\end{tabular}




\begin{tabular}{|c|c|c|}
\hline & $\begin{array}{l}\text { UK } \\
\text { - caring responsibilities (esp. girls) } \\
\text { - }\end{array}$ & \\
\hline \multirow[t]{6}{*}{ Family relationships } & $\begin{array}{l}\text { HR } \\
\text { - parenting styles } \\
\text { - family violence } \\
\text { - low family expectations }\end{array}$ & \\
\hline & $\begin{array}{l}\text { FR } \\
\text { - conflicts with parents, brothers, sisters } \\
\text { - violence } \\
\text { - illness of the parents, loss of a loved one } \\
\text { - parent's separation }\end{array}$ & \\
\hline & $\begin{array}{l}\text { IT } \\
\text { Cuneo } \\
\text { Villafranca (Verona) } \\
\text { - some parents are not able to keep "dialogue \& } \\
\text { conflict }\end{array}$ & \\
\hline & PT & \\
\hline & RO & \\
\hline & $\begin{array}{l}\text { UK } \\
\text { - family related problems } \\
\text { - have other issues such as drug, alcohol } \\
\text { - health issues } \\
\text { - returning to home country for work or arranged } \\
\text { marriages } \\
\text { - break-up of relationships with family }\end{array}$ & \\
\hline \multirow{3}{*}{$\begin{array}{ll}\text { Engagement } & \text { with } \\
\text { education } & \text { and } \\
\text { school } & \end{array}$} & $\begin{array}{l}\text { HR } \\
\text { - low family expectations regarding school }\end{array}$ & \multirow{3}{*}{$\begin{array}{l}\text { The parents need to be motivated" (teacher, } \\
\text { France) or "We need to motivate them (the parents) } \\
\text { (counsellor, France) } \\
\text { There are parents who didn't have a high level of } \\
\text { education but who have children who succeed at } \\
\text { school. There are also parents with high socio- } \\
\text { economic status with children who failed at school. } \\
\text { ESL is complicated and children don't always do } \\
\text { what their parents want them to do. There is a gap } \\
\text { between the parent's expectations and the } \\
\text { children's. How can we do, to make children more } \\
\text { implicated and to listen much better to their needs? } \\
\text { Where is the child's desire? [Social association's } \\
\text { responsible, France] } \\
\text { I did an experiment, I took the list of students } \\
\text { concerned by absenteeism and I called the parents } \\
\text { and I even wake up parents in the morning to tell } \\
\text { them to bring their children! Putting the pressure on } \\
\text { parents works but when the child comes we must } \\
\text { also interest him in school. (teacher France) }\end{array}$} \\
\hline & $\begin{array}{l}\text { FR } \\
\text { - relegation, feeling of incompetence } \\
\text { - adults who don't support children } \\
\text { - misunderstanding on school expectations } \\
\text { - misunderstanding in school missions } \\
\text { - parents who present homework as a punishment } \\
\text { - parents who denigrate school, teachers... } \\
\text { - parents who had problems at school themselves } \\
\text { - parents who devaluate school, and think studies } \\
\text { got no meanings and are useless }\end{array}$ & \\
\hline & $\begin{array}{l}\text { IT } \\
\text { Cuneo } \\
\text { - anxiety, strong sense of helplessness, less } \\
\text { responsive than in the past } \\
\text { - mums are "soft" and not prepared to face } \\
\text { children's fragilities and school phobia } \\
\text { - Influence of family "status" on school choice } \\
\text { - family's lack of awareness on their role in school } \\
\text { issues } \\
\text { - parents' lack of interest/time/engagement in } \\
\text { school issues: they do not attend school } \\
\text { meetings; } \\
\text { - performance pressure: some parents look only at } \\
\text { marks and results } \\
\text { - lack of trust in teachers' work and evaluations } \\
\text { - Italian families' general lack of love towards } \\
\text { school } \\
\text { - school value is not passed down by families } \\
\text { - no value given to studying: working is more } \\
\text { relevant } \\
\text { Villafranca (Verona) } \\
\text { - low educated parents suggest to their low } \\
\text { motivated children to leave school and go to work }\end{array}$ & \\
\hline
\end{tabular}




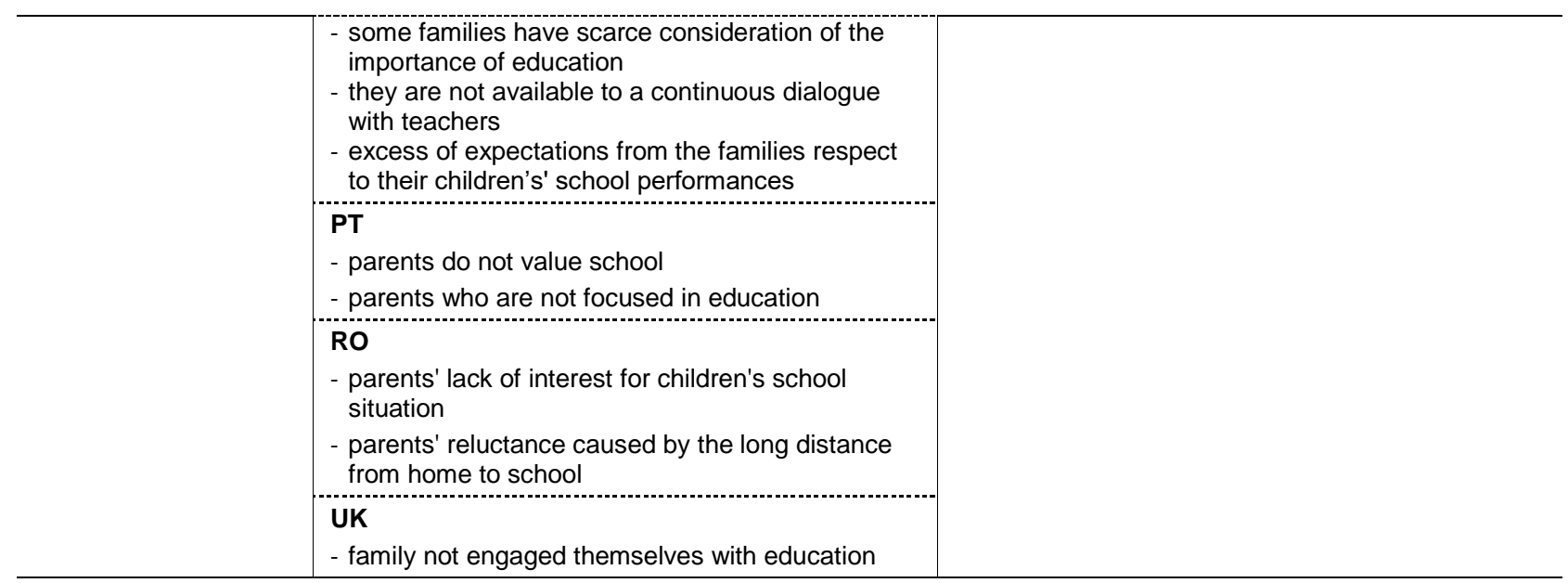

School is, by its own definition, one domain in which the identified aspects causing early leaving are more evident in the speeches of both young and adult participants in all partners' countries (see Table 4.8). In the cases of adults, it was possible to find descriptions that have been gathered in fifth dimensions of the school: pedagogical, relational, organizational, curricular, and vocational. In the first group we have put, as the name indicates, all the examples related with pedagogy. In the second, a dimension connected with pedagogy, but analytically separable, regarding the relationships and ties at school (between pupils and teachers, teachers and families, school staff and students). The third, regarding the school organization. The fourth dimension includes all the aspects related with the school curriculum. Last dimension concerns aspects that students have to deal with when choosing at the school path and when enrolled in vocational courses.

Pedagogical factors are, for example, inadequate/traditional or old teaching styles indicated in all countries and resumed in the UK with the question of the school not suiting the young people educational and individual needs. Elderly teachers are not keen on new methodologies and have low ICT skills, as identified in Croatia. There are not diversified and attractive methods of teaching -referred in general - therefore difficulties to deal with not interested students arise, as pointed in Italy. Different students also require different attention and have different needs that teachers cannot meet. These differences may be in what regards the interest the students show, but also regarding social origins, as highlighted by stakeholders in Portugal. In Romania, teacher's lack of training, in terms of pedagogy and psychology, is pointed. Even lack of vocation, as was referred in Portugal.

I believe that many children find school boring because most of the teachers are using classic and old teaching methods. If they used modern ones - projects, activities to emphasize every child, to assign each pupil with a role and make him/her feel useful. I think this way they would come to 
school with love and enthusiasm. And this is not about the system, it's about us, teachers. Because there are many of us using new techniques and our pupils are delighted; and there are teachers using only classic methods and at the end of the class, children are tired and unwilling to come again to class. We should be taught how to do this, be invited to attend trainings apart from what we know from University. [Teacher, Romania]

[teachers] don't foresee some time for posing questions. So, 'I have a doubt' and several [teachers] answer 'I can't, now'. So, as they have to go on giving the class, kids don't have the time to learn and to think if they have any doubts [Family member, Portugal]

Relational factors include poor or bad interaction between teachers and pupils, as indicated by stakeholders in Croatia, France, Romania and the UK exactly as such. Also, not knowing the difficulties of the students to accept to change and adapt pedagogies, as indicated in France, and what is nearly the same and emerged in Portugal, teachers care little about the learning needs of the students. Alongside, students are treated like they are not engaged when they do not understand, registered in Italy-Cuneo.

They (students) hold on, they are there, but nothing happens, nothing positive is sent back to them by the teacher [Public official France]

The lack of teacher's training and competence in the field of human relation with students - as already showed - and families, pointed in Italy-Cuneo, is even more detailed in Romania, France and Portugal (poor interactions between teachers and parents, social relegation and bad image of parents, difficulties of the school in dialoguing with different families, teachers who do not value parent's role).

They start missing school without giving any reason or they just leave some classes accusing headaches or stomach pain. They do this one day, the next day, and eventually you realize they do not come at all anymore. For this reason, it is very important that the teachers stay in permanent touch with the parents or other relatives. They need to know if the parents are working abroad and leave the children with grandparents, uncles, aunts... [Head teacher, Romania]

Bullying, violence at school are, also, examples of school factors that stakeholders described in France, Italy, Portugal and the UK. Racial and ethnic discrimination is another factor indicated as contributing for failure and ESL in Portugal.

The sensation I have is that the school doesn't know how to deal with the parents. In our case, is the cultural diversity... and sometimes is a little embarrassing to see both the parents talking to teachers as the other way round. I am called to school to deliver a paper to a family; they don't go! The neighbourhood is just across the street and they don't go [Cultural, sports and social association worker or volunteer, Portugal]

Diverse aspects at the organization level of the school were identified by stakeholders as reasons for failure and ESL; they are numerous in the cases of France, Italy (both territories) and Portugal and can be seen in detail in Table 4.7. We highlight some consistencies we find across countries, as we have been doing in this section. 
First, we highlight some aspects regarding staff in general, like overloaded and instable teaching staff due to turnover (both in Italy and Portugal); low level of collaboration within teacher's group and lack of coordination - an unique institutional figure is needed at school (Italy-Cuneo); roles confusion at the critical moments for the youngsters to know who has to intervene teachers or counsellors (France); need of teams with social worker, educational operator, teachers and psychologist (Italy-Cuneo); lack of team working in vocational guidance (ItalyCuneo); lack of operational assistants in schools (Portugal); lack of communication and involvement in the staff (in France); lack of school counselling (Croatia); and too large ratio of students and teachers (in the UK).

Second, questions regarding students: classes are too big to teach (Italy and the UK); the school is historically made for middle and upper class (France); concentration of students with the same socially vulnerable profile in the same school(Portugal); lack of inclusion of some students in their class and school (migrants, new comers, older students, etc.); school seems to be dedicated only to successful students and avoids those with difficulties.

Third, aspects related to rules and norms and other kind of functioning: school is a closed up system with no collaboration (France), has outdated internal regulations (Portugal); there is an incompatibility between job schedule of parents and teachers' availability hours [ItalyVillafranca (Verona)].

For students who drop out and want to come back, it's really very complicated, there is a disorganization of the school system ... devices exist but they are often not applied ... we have a reference school dropout at home it's a CPE (counsellor) but he did not do the job, there was a census of dropouts but no follow up this year, we have a new director who chose to share the work between the three CPE, it's better because it's a lot of work for one » [teacher, librarian, France]

Other features of the school organization that contribute to explain problems leading to ESL include poor or scarcity of funds and equipment (as in Croatia).

Curricular dimensions include: extensive or too demanding curricula (as identified by stakeholders in Croatia and Portugal); inflexible curricula and with too much examination and testing (as in the UK). Also, the inexistence of articulation between the content of the curricula and the outside world, namely information on jobs, professions, training content (Italy-Cuneo and France). Few or lack of practical/ lab activities and extracurricular activities also have been assumed by stakeholders in Italy-Cuneo, Portugal and Romania as underlying causes of failure and ESL. 
It is very important to give motivation to students through extra-school activities: external inputs are productive and have positive insights on school results too, where the risk of low self-esteem is spread. [Vocational and training institution representative, Cuneo, Italy]

Vocational factors were not indicated as factors of ESL in Croatia and the UK. These factors include the lack of support during critical phases of the school path, to choose the following phase (in France was the only mentioned factor related to this dimension), as well as the autonomy the student lacks when having to choose this path (as mentioned in Romania and Portugal).

The aspects of bad or difficult counselling or guidance in vocational courses were highlighted in Italy (both territories) and problems with vocational learning, like its devaluation (in Portugal) or the particular system of selection in Italy-Cuneo worth mentioning here. Other specific details are shown in Table 4.7.

There is a big problem about orientation in school. How can you ask a 14 years old child to choose his dream job and to define how to get to it? We, adults, can't always answer to this question. Did we know at the same age what we wanted to do later and did we get the job we wanted when we were young? [Social worker, France] 
Table 4.8 School factors explaining disengagement and ESL (Stakeholders)

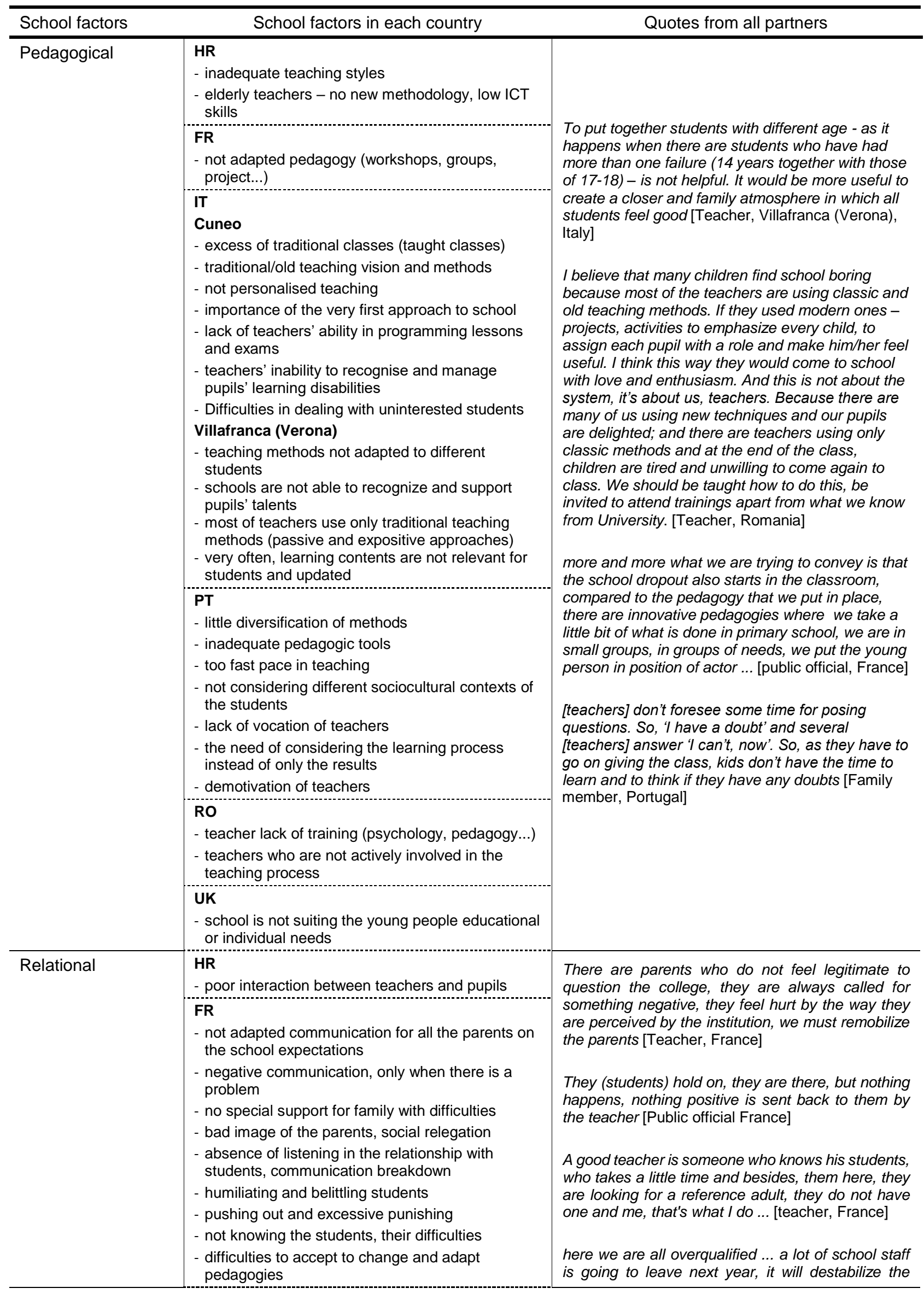




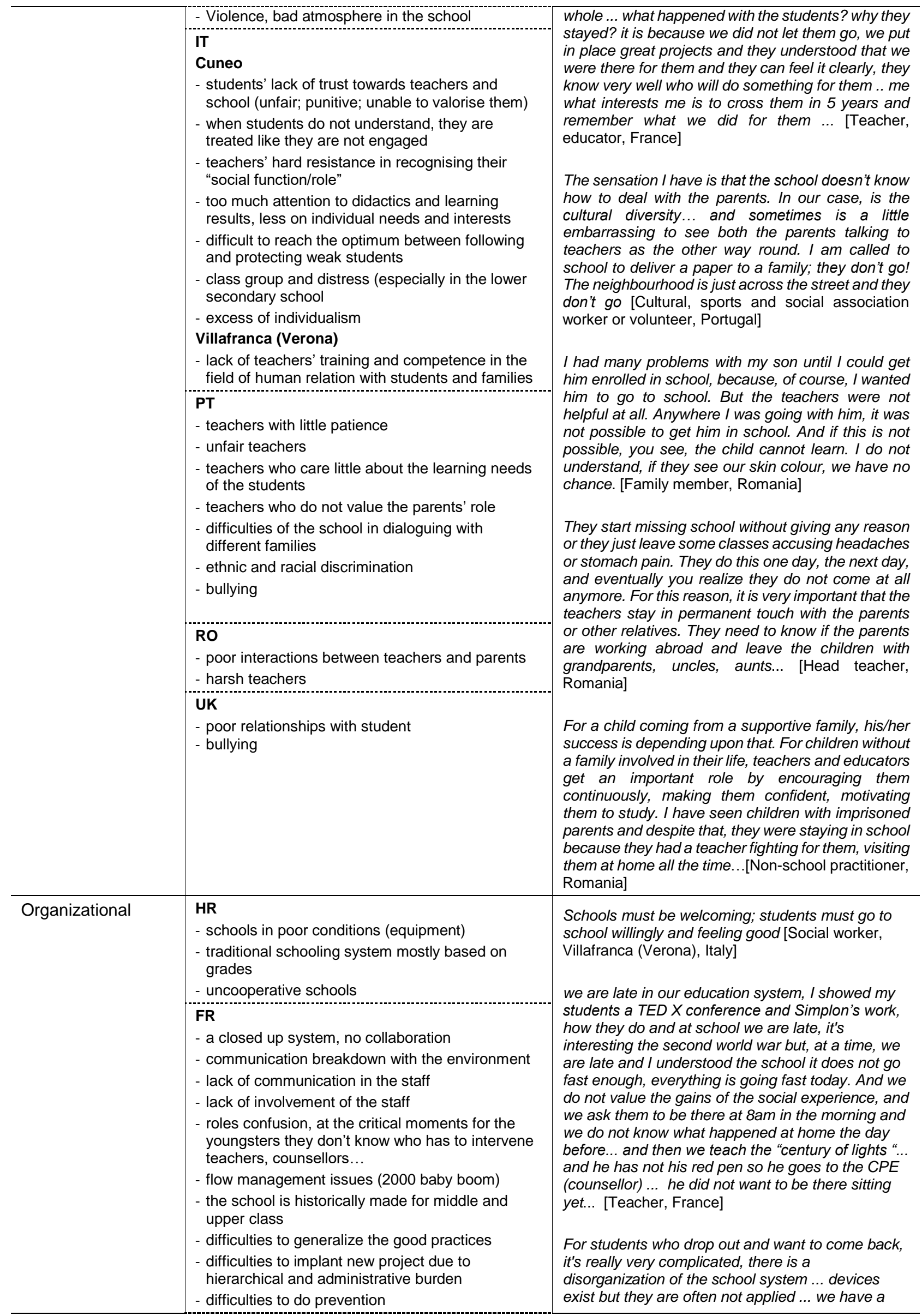




\begin{tabular}{|c|c|c|}
\hline & $\begin{array}{l}\text { IT } \\
\text { Cuneo } \\
\text { - overcrowded classrooms } \\
\text { - overloaded teachers (too many things to do) } \\
\text { - teachers' strong resistance to change } \\
\text { - very high Head teachers' turnover: lack of } \\
\text { continuity of projects or processes } \\
\text { - exam is too selective at the end of lower } \\
\text { secondary education } \\
\text { - schools are too demanding (too much homework) } \\
\text { - schools more interested in performance than in } \\
\text { education/training } \\
\text { - school seems to be dedicated only to successful } \\
\text { students and avoid those with difficulties } \\
\text { - need of teams with social worker, educational } \\
\text { operator, teachers and psychologist } \\
\text { - low level of collaboration within teachers' group } \\
\text { - lack of cooperation among education levels } \\
\text { (lower and upper general secondary school) } \\
\text { - lack of coordination: a unique institutional figure is } \\
\text { needed at school } \\
\text { - lack of team working in vocational guidance } \\
\text { actions } \\
\text { - slowness in sending alerts related to drop out } \\
\text { - lower secondary school not ready to face first } \\
\text { symptoms of distress } \\
\text { - the professionalism of non-school practitioners is } \\
\text { not recognised } \\
\text { - teachers' job insecurity and frustration } \\
\text { Villafranca (Verona) } \\
\text { - incompatibility between job schedule of parents } \\
\text { and hours of availability of teachers } \\
\text { - lack of inclusion of some students in their class } \\
\text { and school (migrants, new comers, older students } \\
\text { who are repeating school years, etc. } \\
\text { - schools are not able to cooperate with "external } \\
\text { educational agencies" }\end{array}$ & $\begin{array}{l}\text { reference school dropout at home it's a CPE } \\
\text { (counsellor) but he did not do the job, there was a } \\
\text { census of dropouts but no follow up this year, we } \\
\text { have a new director who chose to share the work } \\
\text { between the three CPE, it's better because it's a lot } \\
\text { of work for one " [teacher, librarian, France] }\end{array}$ \\
\hline & $\begin{array}{l}\text { PT } \\
\text { - instability/teaching staff turnover } \\
\text { - outdated internal regulations } \\
\text { - earliness in retentions, which generates } \\
\text { demotivation } \\
\text { - lack of operational assistants in schools } \\
\text { - concentration of students with the same socially } \\
\text { vulnerable profile in the same school } \\
\text { - lack of knowledge regarding the students' } \\
\text { universe and disrespect regarding their autonomy }\end{array}$ & \\
\hline & $\begin{array}{l}\text { RO } \\
\text { - lack of school counselling ( } 800 \text { pupils allocated to } \\
1 \text { school counsellor) } \\
\text { - lack of public funds for school improvement }\end{array}$ & \\
\hline & $\begin{array}{l}\text { UK } \\
\text { - class size too big to teach } \\
\text { - ratio of students: teachers too large }\end{array}$ & \\
\hline \multirow[t]{3}{*}{ Curricular } & $\begin{array}{l}\text { HR } \\
\text { - extensive curricula }\end{array}$ & \multirow{3}{*}{$\begin{array}{l}\text { It is very important to give motivation to students } \\
\text { through extra-school activities: external inputs are } \\
\text { productive and have positive insights on school } \\
\text { results too, where the risk of low self-esteem is } \\
\text { spread. [vocational and training institution } \\
\text { representative, Cuneo, Italy] }\end{array}$} \\
\hline & $\begin{array}{l}\text { FR } \\
\text { - lack of concrete information on the jobs, } \\
\text { professions, trainings content.... }\end{array}$ & \\
\hline & $\begin{array}{l}\text { IT } \\
\text { Cuneo } \\
\text { - no connection between school contents and the } \\
\text { real world }\end{array}$ & \\
\hline
\end{tabular}




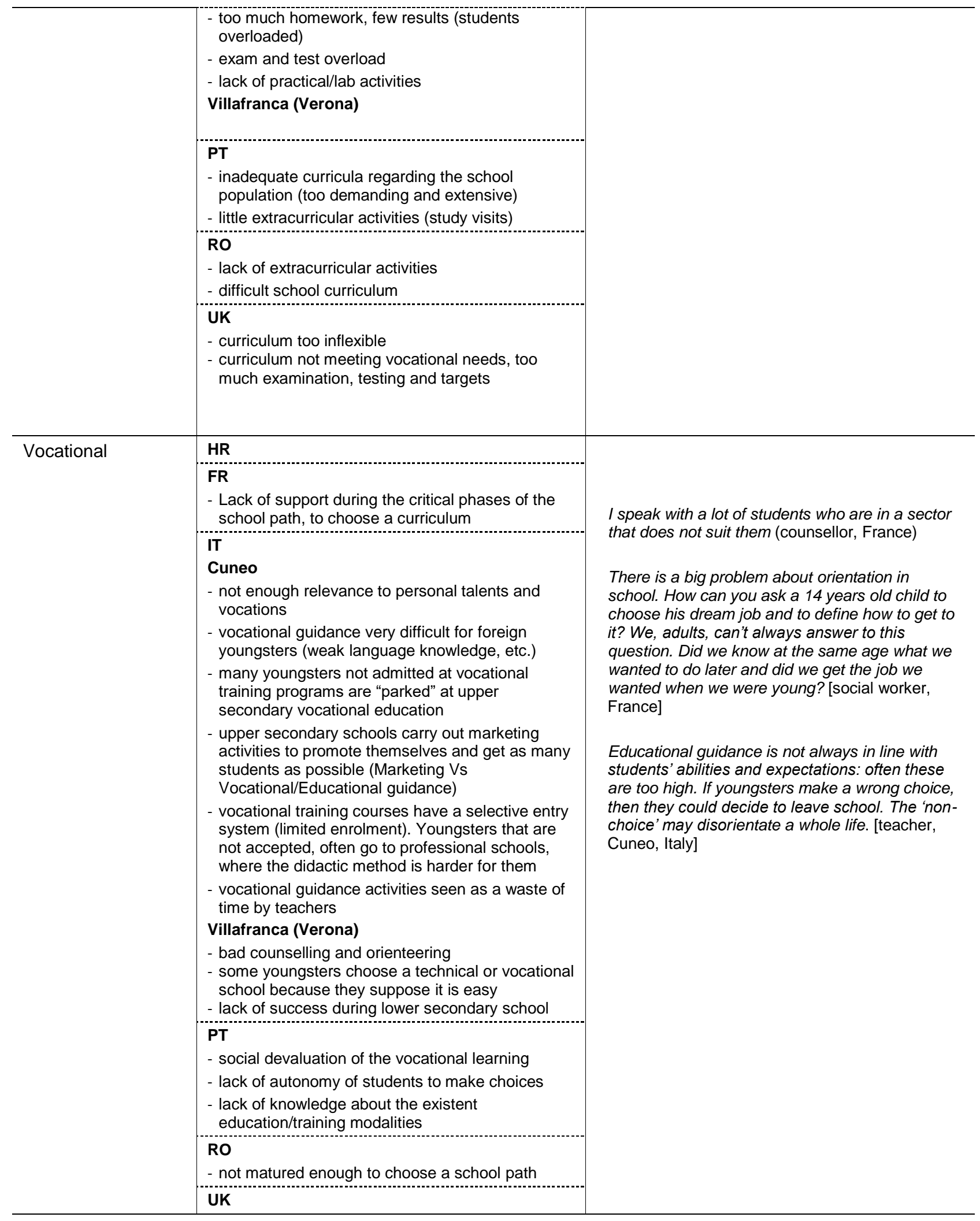

Several community factors (see Table 4.9) are identified by stakeholders in every country as conducting to ESL. We can analytically separate them from previous factors, although having impact on students, families and the school. They correspond to conditions of existence and consist, so say the ones that cross all countries: poverty/economic deprivation, long term or 
current unemployment, social marginality/drug traffic/easy money/violence/danger in the neighbourhoods (later not identified in the UK), low skilled populations.

The lack of confidence or mistrust regarding school and other institutions is a common feature underlined in Italy and Portugal as generating failure.

Other aspect is the dropout of friends as triggering ESL (in Croatia, Italy in both territories and in Romania this factor was focused). Speaking of following bad examples, or role models, in Italy, France and in Romania this dimension came out from the speeches: in the first two cases, both the inexistence of examples of education in the neighbourhood who represent a figure of identification, and the choices of role models associated to sport, businesses, stars; in the second, only this second situation of taking as role models rich people promoted by the media and with low levels of education.

The absence of perspectives for young people, stemming from this overall picture of the conditions of existence was highlighted by the stakeholders in Italy and in Portugal.

We should focus on the importance of a 'learning community': not only teachers, but the whole community should aim at giving youngsters the idea that studying and learning have effects on their personal growth but also on their social identification. To do this, even the involvement of enterprises is essential. [Researcher, Cuneo, Italy] 
Table 4.9 Community factors explaining disengagement and ESL (Stakeholders)

\begin{tabular}{|c|c|c|}
\hline Community factors & Community factors in each country & Quotes from all partners \\
\hline \multirow[t]{3}{*}{$\begin{array}{l}\text { Conditions of } \\
\text { existence }\end{array}$} & $\begin{array}{l}\text { HR } \\
\text { - poverty and poor living conditions } \\
\text { - social disorder within community } \\
\text { - high unemployment rate } \\
\text { - job opportunities - close to the state border - } \\
\text { emigration and/or further education in } \\
\text { neighbouring countries } \\
\text { - lack of professional services for youngsters } \\
\text { - dystopia in the society } \\
\text { - no database of prevention } \\
\text { institutions/organisations } \\
\text { - dropout of friends }\end{array}$ & \multirow{3}{*}{$\begin{array}{l}\text { There is another scourge, it is the absence of social } \\
\text { mix, classes garbage, ghettoized... [counsellor, } \\
\text { France] } \\
\text { We are overwhelmed by social problems, } \\
\text { psychoaffective ...for girls there are pregnancies } \\
\text { that force to stop schooling but I do not see a } \\
\text { difference between girl and boy ... there are mostly } \\
\text { families who accumulate difficulties [nurse, France] } \\
\text { I think that this crisis question... there is no } \\
\text { employment, so as of some age they acknowledge } \\
\text { that and it undermines [the engagement]. As I } \\
\text { already said, most parents have low skills. The } \\
\text { perspectives are not many, so they think to } \\
\text { themselves: 'why am I going to study? After that I } \\
\text { will not have a job'. So there is a lot of that, also." } \\
\text { [Family member, Portugal] } \\
\text { the social mix is important because with the middle } \\
\text { classes come other conceptions of school, of } \\
\text { success by knowledge, by school ... often our } \\
\text { students arrive with a relatively weak schooling and } \\
\text { for them the social success do not really go to } \\
\text { school [teacher, librarian, France] } \\
\text { We should focus on the importance of a 'learning } \\
\text { community': not only teachers, but the whole } \\
\text { community should aim at giving youngsters the } \\
\text { idea that studying and learning have effects on } \\
\text { their personal growth but also on their social } \\
\text { identification. To do this, even the involvement of } \\
\text { enterprises is essential. [researcher, Cuneo, Italy] }\end{array}$} \\
\hline & $\begin{array}{l}\text { FR } \\
\text { - high level of poverty } \\
\text { - violent neighbourhood } \\
\text { - noisy neighbourhood } \\
\text { - emptiness } \\
\text { - drug traffic, delinquency, easy money } \\
\text { - unemployment } \\
\text { - discriminations on the employment field } \\
\text { - feeling of discrimination } \\
\text { - no example of success by education in the } \\
\text { neighbourhood, in the society } \\
\text { - no hope in education } \\
\text { - feeling of abandonment by the state } \\
\text { - feeling of relegation } \\
\text { - harassment } \\
\text { - no network or a not efficient network for } \\
\text { education } \\
\text { - no example of success by education in the } \\
\text { family, the neighbourhood, the persons who } \\
\text { represent a authority (figure of identification) } \\
\text { - model of success is not in studies (sport, } \\
\text { business, stars, people...) }\end{array}$ & \\
\hline & $\begin{array}{l}\text { IT } \\
\text { Cuneo } \\
\text { - absence of role models } \\
\text { - common correlation between school success and } \\
\text { failure in finding a job } \\
\text { - unemployment } \\
\text { - the current uncertain social and economic } \\
\text { situations do not offer a future to youngsters } \\
\text { - high rate of employment in the province of Cuneo: } \\
\text { no need to study longer } \\
\text { - Lack of confidence in institutions } \\
\text { - Lack of a common system/action against ESL } \\
\text { - lack of concrete answers } \\
\text { - high incidence of dropout in the community } \\
\text { - crisis of social, ethical and inclusive values } \\
\text { Villafranca (Verona) } \\
\text { - social marginality } \\
\text { - lack of networking among all actors that should } \\
\text { fight against ESL and implement youth policies } \\
\text { - lack of educators and adults that can be an older } \\
\text { point of reference for young people who are a } \\
\text { mess } \\
\text { - the high level of unemployment (among young } \\
\text { people without specialization) provokes an } \\
\text { increasing number of NEETS, who fall in a loop of } \\
\text { demotivation towards life and very low self- } \\
\text { esteem }\end{array}$ & \\
\hline
\end{tabular}




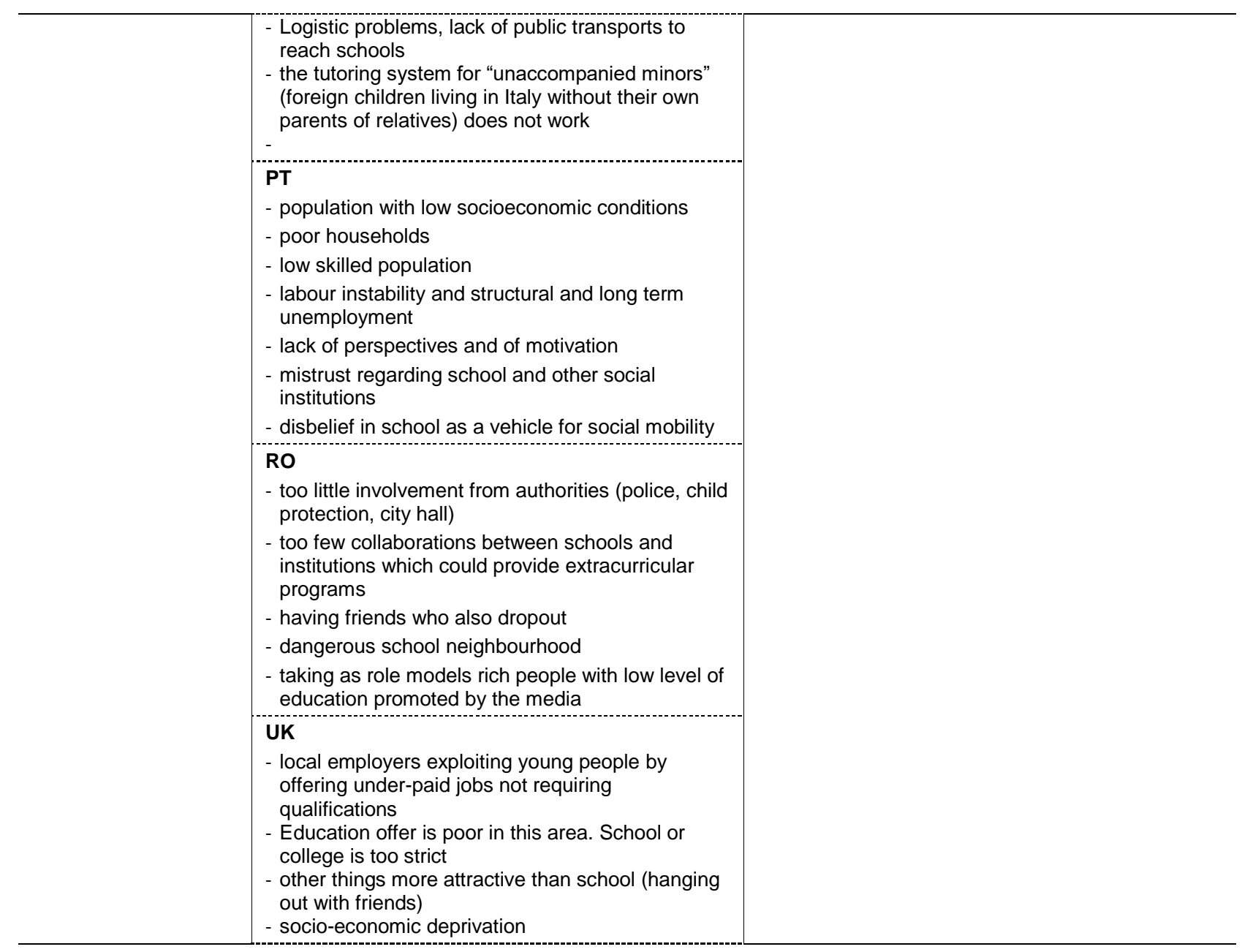




\section{IDEAS FOR ACTION: RECOMMENDATIONS FROM PARTICIPANTS}

Young people and stakeholders were asked in the interviews and focus group to reflect on recommendations to reduce early school leaving and improve school success. The recommendations were, in the analysis, grouped in four categories according to the leading role in implementing or developing each recommendation: students, family, school, community. The detailed recommendations of young people and adults, by partner's country, and by category, are shown in tables 5.1 and 5.2 at the end of this chapter.

The recommendations of both young and adult participants were quite similar and even complementary. For this reason, they are not distinguished in the presented analytical synthesis.

In what regards family, the main recommendations were:

- to reinforce presence of families in schools;

- to give families the skills to support and accompany youngsters in school and help to build their confidence;

- to support families and students with school duties and other kinds of support;

- to educate and help families to discover their role in valuing school and education;

- to provide financial aid to families, to award more students with scholarships, free books and free transport;

- to intensify family-school ties, through activities that show positive examples of the students' work and performance;

- to provide information to families about the education tracks available to their children.

Among the recommendations towards schools and education systems identified by youngsters and stakeholders in all countries, many hold similar objectives. Summing up these shared recommendations, we highlight:

- to adapt curricula to young people, making it more attractive, shorter, less demanding, with dynamic projects and activities;

- to reinforce practical classes;

- to increase extra-curricular activities;

- to diversify the composition of classes;

- to improve relationships between students and teachers; 
- to develop and improve relationships between the school and the parents, with the school being open to them in a perspective of mutual cooperation and friendly exchange of knowledge and experiences;

- to implement more and better school/career guidance;

- to improve communication between members of the school staff;

- to tackle bullying and all forms of violence;

- to create and develop interdisciplinary teams (with social workers, psychologist, youth workers);

- to change school organization and pedagogies;

- to cooperate with the school surroundings and context;

- to work on the school internal relationships;

- to cooperate with families;

- to individualize and make more flexible the school path.

Regarding the recommendations specifically targeted to teachers, the main recommendations are:

- to get teachers to explain better;

- to invest in teachers that could build closer relationships with students and are able to motivate;

- to make teachers developing relationships with family;

- to improve teachers' training;

- to increase awareness of social difficulties of the students among teachers;

- to develop innovative pedagogies, personalise strategies and increase cooperative learning methods.

In what regards community, we unfold the overall set of recommendations:

- to build and develop effective networks of stakeholders;

- to create a network of services working with youth;

- to create ways of shifting from school to jobs;

- to create awareness campaigns on the importance of school education;

- to create conditions for the interaction between pupils and adults who have a good career reached through education; 
- to promote social and large visibility to youngsters of success trajectories and paths due to education;

- to fight against unemployment, poverty and discrimination;

- to fight against drugs, violence and crime.

We can also analyse these recommendations using another dimension: the underlying type of action in each. As already stated in some European reports, effective actions against early school leaving need to encompass a combination of prevention, intervention and compensation actions and policies (European Commission, 2017; Council of the European Union, 2011; European Commission, 2013). ${ }^{56}$ The measures recommended by the young people and adults consulted in the research cover those three domains. However, they focus mainly on intervention and compensation.

Prevention focuses on processes leading to early school leaving. Successful prevention of early school leaving ponders the requirements for successful schooling, such as, according to the respondents:

a) articulation - developing comprehensive education strategies involving several professionals, partners and entities;

b) precocity - deploying earlier measures in the educational systems; focusing on early stages of education;

a) connection - creating stronger and meaningful connections between students and teachers, improving teachers' attitudes towards the pupils, preparing the teachers to interact with young people and becoming more respectful and caring;

c) belonging - forming sense of belonging and preventing alienation and lack of identification, particularly in large school complexes;

b) focus - targeting and focusing specific groups, particularly in those students at higher risk of early school leaving (such as children who are socioeconomically deprived and/or have a migrant or Roma background, or with special educational needs);

\footnotetext{
56 European Commission (2017), European Semester thematic factsheet Early school leavers. Council of the European Union (2011), Council Recommendation of 28 June 2011 on policies to reduce early school leaving (2011/C 191/01), Official Journal of the European Union, C 191, 1 July 2011. European Commission (2013), Reducing early school leaving: Key messages and policy support. Final report of the Thematic Working Group on Early School Leaving.
} 
c) guidance - developing better guidance systems, helping young people understand their own strengths, talents, different study options and employment prospects; provide young people with the information they need to make informed education and career choices; and offer quality and up to date guidance information at an early educational stages, bearing in mind particular needs and circumstances;

d) diversifying school staff - including non-teacher school staff such as psychologists, social workers, attendance counsellors, child and youth workers, educational assistants to support student learning and school climate;

e) participation - actively involving pupils and parents in decisions towards the school and its operational processes and organization, valuing young people's opinions.

f) relevance - designing relevant and coherent curricula, in such a way that it reflects the different affinities of the pupil, takes into account different starting points, and is adapted to the pupil's ambitions; to connect the curricula and the educational activities with "real life"; to use the skills that pupils have already acquired in their everyday lives as a reference to build the process of teaching, and to teach towards resources, more than on deficits.

g) innovation -teaching models and pedagogies should be newer, meaning changes and improvement in the learning environment; preparing teachers with the skills to adopt inclusive and student-focused methods; increasing time in school activities outside the classroom; creating practical laboratories.

Intervention addresses emerging difficulties and seeks to prevent early school leaving. It applies to all pupils, but is particularly relevant to those at risk of early school leaving. Intervention includes measures such as:

a) personalization and diversification - implementing early warning systems capable of triggering personalised prevention and intervention measures; empowering teachers to identify different learning styles and the pupils' needs;

b) positive climate - promoting positive and protected school climate (avoidance of physical violence and bullying); establishing good relationships and positive interactions capable of reduce fear of failure and stress; preparing teachers with conflict resolution skills to promote a positive classroom climate; 
c) cooperation - promoting cooperation and relationships between schools, parents, peers, decision makers, teachers; establishing interdisciplinary teams and 'professional communities'; strengthening the links between persons interested in the ESL problem;

d) continuous education for education staff - offering continuous professional development of teaching staff; supporting teachers with training in dealing with the high diversity of classrooms; prepare teachers to work with other professionals and partners to prevent ESL;

e) cross-sector approaches -to tackle early school leaving, these approaches mean involving the local education system, employers, labour market services, social services, health services and community organisations and connect school and non-school actors and activities, such as new types of teaching and tutoring (in-school) and out-of-school activities and partnerships (work experience, leisure activities, mentoring, ...)

Compensation measures provide education and training opportunities for those youngsters who have dropped out. They are meant to reintegrate youngsters back into education and training and to facilitate their passage to secure and meaningful employment. Therefore, they are measures related to flexibility and information.

a) Flexibility - creating flexible alternative quality pathways to gaining the qualifications necessary for transitions to further education or employment.

b) Information - developing better information systems about re-engagement and qualification options.

Finally, more detailed recommendations of young people and adults, by country and by category, are shown in the following tables 5.1 and 5.2 . 
Table 5.1 Young people's recommendations by country and category

\begin{tabular}{|c|c|}
\hline Countries & Recommendations to what or whom are targeted \\
\hline HR & $\begin{array}{l}\text { School } \\
\text { - More opportunities for work and employment - education needs a more up to date curriculum } \\
\text { - Right to choose subjects } \\
\text { - School as place of connections } \\
\text { - Learning useful and practical skills } \\
\text { Teachers } \\
\text { - Relations between teachers and students should be improved } \\
\text { Community } \\
\text { - A proper and official network or service of institutions working with youth and youngsters should be set up } \\
\text { - More projects and activities should be carried out to improve the infrastructure for education to offer a range } \\
\text { of activities and social engagement of youngsters in rural areas } \\
\text { More scholarships should be given; free books, free public transport }\end{array}$ \\
\hline FR & $\begin{array}{l}\text { Family } \\
\text { - Parents involved in education } \\
\text { - Projects together } \\
\text { - Parent-child play group } \\
\text { - Confidence building } \\
\text { School } \\
\text { - Adapting courses to pupils } \\
\text { - Doing more activities outside school and digital projects } \\
\text { - Reducing courses and homework (sometimes, there's no link with the discipline) } \\
\text { - Favouring success by new methods } \\
\text { - To avoid repetitive programs without interest } \\
\text { - To prevent bullying } \\
\text { - To show the school's good sides } \\
\text { - Let young people choose what they really want (orientation) } \\
\text { - Less pupils in the classroom } \\
\text { - Proposing support to young people } \\
\text { - Changing the way of orientation } \\
\text { - More contacts between school staff and parents } \\
\text { - Opening school to parents } \\
\text { - Do not make parents feel guilty } \\
\text { Teachers } \\
\text { - Taking time to explain } \\
\text { - Listening and talking more to young people } \\
\text { - To explain differently } \\
\text { - Using more discussion instead of punishment } \\
\text { - No humiliations and favouritism } \\
\text { - Changing the way of evaluating by including the pupil's progress } \\
\text { - Favour links between teachers and pupils } \\
\text { Community } \\
\text { - Fighting against crime, drugs, ... } \\
\text { - To not ghettoize districts } \\
\text { - To respect more the youngsters } \\
\text { - Supporting and building capacity in the schools } \\
\text { - To reduce unemployment } \\
\text { - Opening school to the labour market and vice versa } \\
\text { - More support from the government } \\
\text { - }\end{array}$ \\
\hline IT & $\begin{array}{l}\text { Cuneo } \\
\text { Family } \\
\text { - Poor family financial support } \\
\text { School } \\
\text { - More cooperation between school and families } \\
\text { - More efficient career/school guidance } \\
\text { - Organise more and more "school-job alternation" activities (internships in enterprises) }\end{array}$ \\
\hline
\end{tabular}




\begin{tabular}{|c|c|}
\hline & $\begin{array}{l}\text { - Psychological youth and family support } \\
\text { Villafranca (Verona) } \\
\text { School } \\
\text { - More activities of "alternation school-job" (internships in enterprises) } \\
\text { - More workshops and practical activities } \\
\text { - More ICTs and innovative methods } \\
\text { - Topics and contents more relevant for young people's life } \\
\text { - Change the students' evaluation system: it should be less competition-oriented and more supportive } \\
\text { - Enhance the "second chance" school system: many people dropped out - like us - can be reintroduced in } \\
\text { formal education when they are older } \\
\text { - Peer learning }\end{array}$ \\
\hline PT & $\begin{array}{l}\text { Family } \\
\text { - To reinforce the presence of more vulnerable families and tutors (for them to be present, to support and } \\
\text { follow the youngsters when doing homework) } \\
\text { - To give families the skills to support and accompany youngsters regarding school } \\
\text { School } \\
\text { - To implement artistically, sport and school stimulating, dynamic and attractive projects and activities, that } \\
\text { offer visibility to the school and students and would help to build competences, confidence and self-esteem } \\
\text { - To organize mixed classes (with students both with more difficulties and with less difficulties); } \\
\text { - To decrease the workload of the vocational and professional courses } \\
\text { - To value the vocational and training courses } \\
\text { - To bet in shorter courses } \\
\text { - Be receptive to students' opinions (e.g. creating a suggestions box) } \\
\text { - To reinforce the practical classes } \\
\text { Teachers } \\
\text { - To bet in tutorials and on accompanying students on a close basis } \\
\text { - To bet in proximate teachers with adequate profiles, who would be able to motivate and to chat about future } \\
\text { possibilities of life } \\
\text { - To promote the qualification and improve the quality of the staff. }\end{array}$ \\
\hline RO & $\begin{array}{l}\text { Family } \\
\text { - Parents' involvement in children's education } \\
\text { - Better relationship between children and parents } \\
\text { - Family counselling } \\
\text { School } \\
\text { - More attractive classes } \\
\text { - School curriculum based on critical thinking and acquiring competences } \\
\text { Teachers } \\
\text { - Kind and involved teachers } \\
\text { Community } \\
\text { - Awareness campaigns on the importance of school education } \\
\text { - Interaction between pupils and adults with a good career reached through education } \\
\text { - Financial aid from the state in order for youngsters to stay in school }\end{array}$ \\
\hline UK & $\begin{array}{l}\text { School } \\
\text { - Tackle bullying } \\
\text { - Clamp down on bullying } \\
\text { - School be more flexible in curriculum offer (not just academic) } \\
\text { - Provide bespoke courses to match students' interests. } \\
\text { - Provide consistent support } \\
\text { - School should be more flexible to accommodate student's choices } \\
\text { - Relax school uniform rules } \\
\text { - Clear rules, consistently applied } \\
\text { - School providing pastoral support } \\
\text { - School providing work-placement opportunities. } \\
\text { - Schools being a safe place } \\
\text { - Students see link between learning and work. Tolerance } \\
\text { - Secure peer friendships for every student } \\
\text { - Understand mental health and emotional stresses, listen to students - don't assume and label }\end{array}$ \\
\hline
\end{tabular}




\begin{tabular}{l|l} 
- Get students to stay on task \\
Teachers \\
- Teachers be more understanding of things that are not just educational targets \\
- Reduce pressure at school, teachers be more understanding of individuals' needs, mentors needed to stop \\
students from dropping out. \\
- Teachers should understand students' emotional needs better. \\
- Get teachers to explain better \\
- Provide lessons that are not boring \\
- Teachers advocate for students \\
Community \\
- Get rid of drugs
\end{tabular}

Table 5.2 Stakeholders' recommendations by country and category

\begin{tabular}{|c|c|}
\hline Countries & Recommendations to what or whom are targeted \\
\hline HR & $\begin{array}{l}\text { Family } \\
\text { - Family has the key role in motivating and decision making } \\
\text { School } \\
\text { - School and teachers have an important role, but less influence } \\
\text { - School and parents need to cooperate more closely } \\
\text { - Teachers and educators have to be more socially responsible and cooperative, opened to new skills and } \\
\text { knowledge improvement/upgrading } \\
\text { - Continuous statistics that accompany students through their education throughout their lives } \\
\text { - Verification and sanctions for not achieved goals and tasks in education strategies } \\
\text { Teachers } \\
\text { - School and teachers have an important role, but less influence } \\
\text { - Head teachers and professional services need to be more supportive to teachers } \\
\text { - Continue to implement teaching assistants' services in the schools } \\
\text { Community } \\
\text { - The red tape (bureaucracy) } \\
\text { - Organization of half-day stays for children in each neighbourhood } \\
\text { - Implement parents' schools before through - mobile teams that would be accessible to everyone, before } \\
\text { involving children in schools } \\
\text { - Networking }\end{array}$ \\
\hline FR & $\begin{array}{l}\text { School } \\
\text { Change school organization } \\
\text { - Underlined and generalize the good educational practice } \\
\text { - Clarified the school missions, the roles of the school staff } \\
\text { - Work on the relation with the students } \\
\text { - Implement a watchfulness process to intervene at the right time } \\
\text { - Develop small or medium size school } \\
\text { - Avoid categorizing the children ("hyperactive", "terrible", "poor", "shy",...) } \\
\text { - Reinforce the all school staff training } \\
\text { Change the pedagogy } \\
\text { - Make understand the sense of the school } \\
\text { - Fighting against turn-over of school staff } \\
\text { - Develop alternative pedagogies } \\
\text { - Adapting methods to students } \\
\text { - Work with the project methodology } \\
\text { - Introduce more workshops } \\
\text { - Introduce coaching at school } \\
\text { - Change the evaluation system } \\
\text { - Value social skills } \\
\text { - Underline the success of the students }\end{array}$ \\
\hline
\end{tabular}




\begin{tabular}{|c|c|}
\hline & 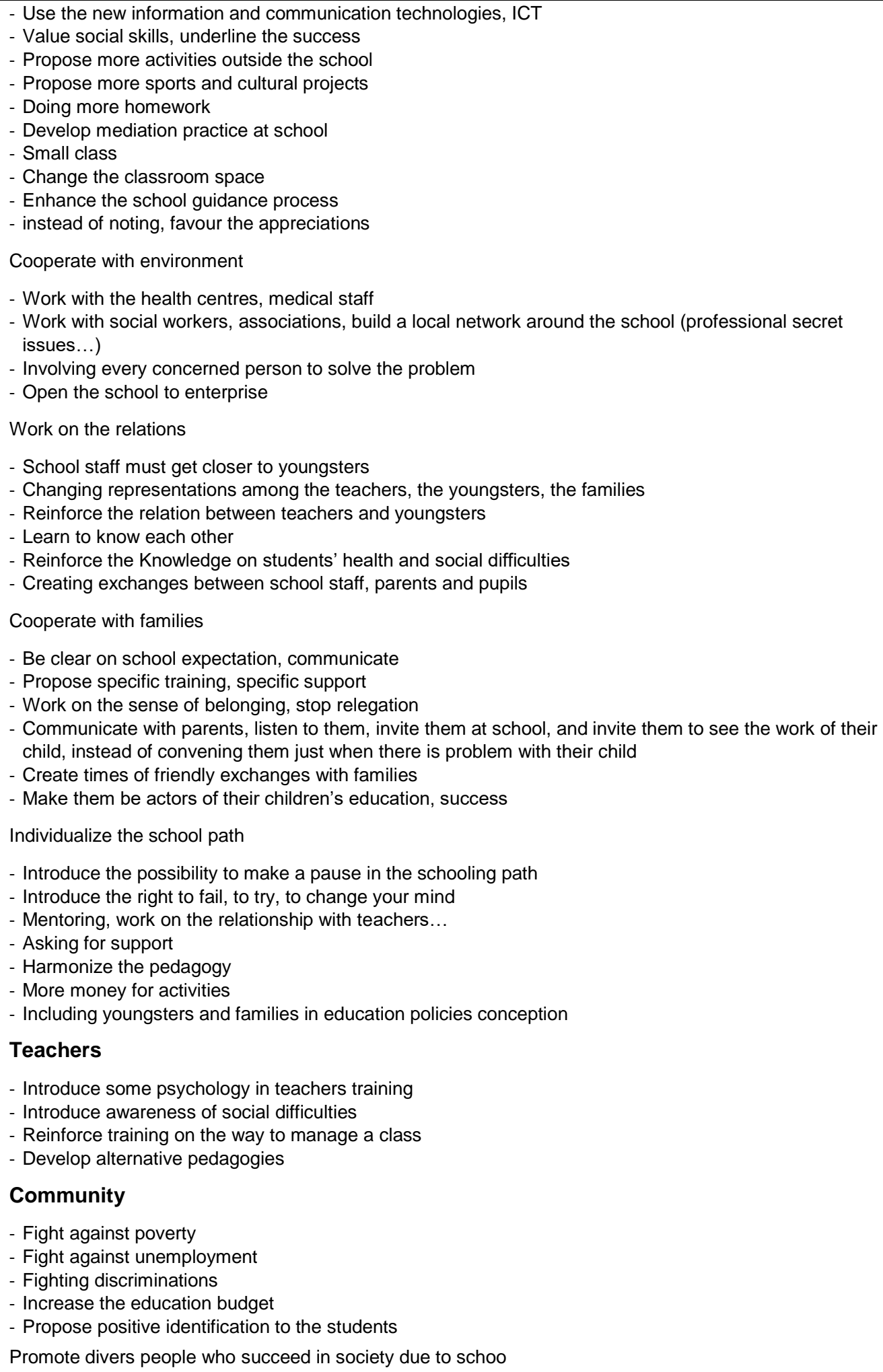 \\
\hline IT & $\begin{array}{l}\text { Cuneo } \\
\text { Family } \\
\text { - To foster support to families } \\
\text { - Help families in discovering school value and importance } \\
\text { FAMILY-SCHOOL RELATION: } \\
\text { - Involving families for prevention, by primary school } \\
\text { - More family-teachers dialogue is needed }\end{array}$ \\
\hline
\end{tabular}




\section{School}

- A stronger connection between lower and upper secondary school (system change suggestion: a training address for the three-year period and a two-year merged period)

- Connection and vertical curriculum among different school grades

- Schools system reform: re-organisation of the workload

- More attention to teachers' wellbeing (overloaded, stressed by job insecurity)

- Vocational guidance more focused on individual needs and talents | More effective preventive actions: if vocational guidance and choices are well based, the risk of drop out is reduced.

- Giving motivation to students through extra-school experience activities (practical and social/voluntary activities to discover personal talent)

- Promoting students' visits to work places

- Mapping of projects: good practices exchange

- Good projects: counselling offices at school, support on studying methods, etc.

- Financial resources are needed for continuous work

- Language courses for foreign students; Specific tools/actions for foreign students

- Prevention: more financial resources, more coordinated and continuative projects

\section{Teachers}

\section{TEACHERS' ROLE:}

- Direct and personal contact with dropped out students

- Teachers long-life learning on pedagogical aspects and disabilities

- Task force at secondary school

- Working to create a good environment in classroom

- Peer tutoring

- Peer education

\section{TEACHING METHODS:}

- Personalised strategies

- More attention to different intelligences

- Inclusive didactic method (active lecture, not frontal)

- Teaching workshops

- Cooperative Learning methods

- More labs, workshops and practical activities

- Personalised teaching and labs are needed; towards new didactics?

\section{TEAM WORK:}

- Need of an inter-institutional team and dialogue on ESL, school distress and specific cases (periodica boards, meetings, reports) and on vocational guidance

- Cooperation among the teachers' board

- Institutional agreements among schools

- To formalise the presence of an educator or a counsellor within the schools (for individual or group activities)

- Involvement of all actors (institutions, schools, social partners, families, voluntary association, ...)

- Training and exchange programs among teachers of different levels of education (Lower and Upper secondary general education)

\section{Community}

- Building up a common issue among actors, continuity of actions.

\section{Villafranca (Verona)}

\section{Family}

- To create new services for families' support

- To support poor students with free provisions of books and other didactic materials

\section{School}

- The two first years of higher secondary school should have a uniform structure, and the choice of a more academic or more practical education, as well the choice of a more specific field of subjects, should be postponed at the moment in which pupils are $15-16$ years old.

- To leave schools open during the afternoon and to promote a wide range of activities and workshops for youngsters. This can require the provision of canteen too.

- Schools should be for students a positive, calm and relaxing environment. It's necessary to avoid the "performance anxiety

- Lower and higher secondary school should be a place of learning and support to personal fulfillment of all students, more than a place of meritocracy. Selection of best students, in the contemporary society, can happen later, at University.

- To involve families in school life 


\begin{tabular}{|c|c|}
\hline & $\begin{array}{l}\text { - To involve sport coachers in the fight against ESL. } \\
\text { - To improve "relational climate" at school (good relations among peers and between students and } \\
\text { teachers) } \\
\text { - To improve the quality of school buildings: school should be a beautiful and comfortable place } \\
\text { Teachers } \\
\text { - Learning innovative approaches, in order to increase students' motivation. } \\
\text { - Head teachers should play a strong role in motivating teachers towards change and improvement, both in } \\
\text { the field of positive relations with students and in the field of didactic innovation } \\
\text { - To experiment the "case manager": an expert who is in charge of supporting and tutoring of an individual } \\
\text { student "off the rails", able to put into connection all involved actors. } \\
\text { - To develop reward schemes for the best teachers } \\
\text { Community } \\
\text { - Effective networking among schools, local institutions, social services, associations, etc. Even the so called } \\
\text { "fourth sector" (networks of relatives, friends, neighbors) must be activated in order to support the most } \\
\text { fragile youngsters } \\
\text { - To invent and practice new ways of alternation school-job, in order to reduce the number of NEETS and try } \\
\text { to recover them through practical and satisfying activities } \\
\text { - To involve demotivated students and NEETS in volunteering activities for the community. }\end{array}$ \\
\hline PT & 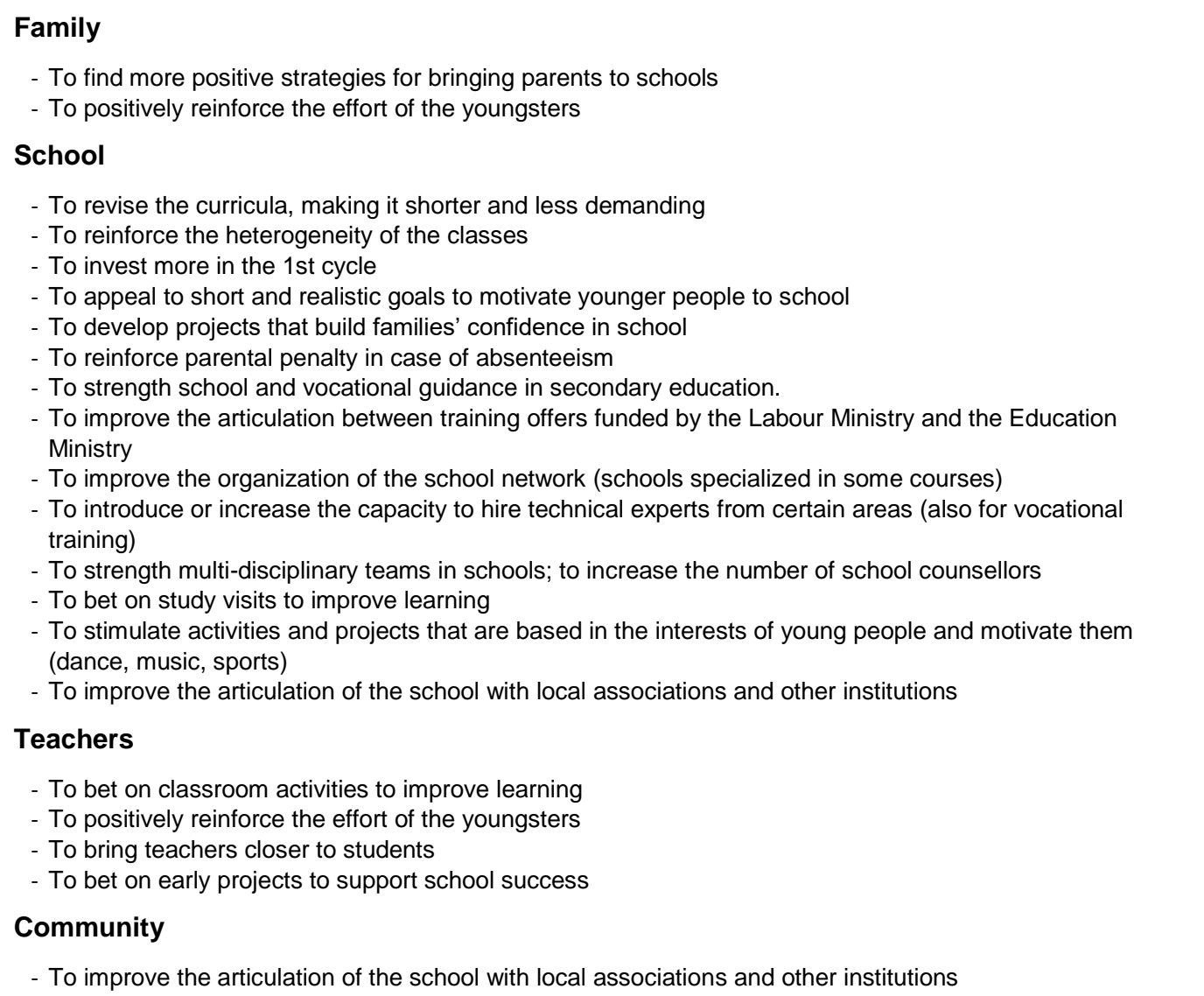 \\
\hline RO & $\begin{array}{l}\text { Family } \\
\text { - A good collaboration between teachers and parents } \\
\text { - Financial help for disadvantaged families in order to encourage school attendance } \\
\text { School } \\
\text { - After school program in every school (free access } \\
\text { - Extracurricular activities } \\
\text { - School / professional orientation programs for pupils } \\
\text { - School curriculum containing practical activities, not only theory } \\
\text { - Fewer pupils allocated to } 1 \text { school counsellor } \\
\text { - School involvement in informing parents on the importance of education } \\
\text { - Rewards for pupils with good results (scholarships, trips etc.) }\end{array}$ \\
\hline
\end{tabular}




\begin{tabular}{|c|c|}
\hline & $\begin{array}{l}\text { Teachers } \\
\text { - A good collaboration between teachers and parents } \\
\text { - Training programs for teachers in order to learn new teaching methods } \\
\text { - Rewards for teachers who support disadvantaged pupils to start / continue school } \\
\text { Community } \\
\text { - A better cooperation between institutions with various expertise areas } \\
\text { - A clear methodology for the situations where children do not attend school (prevention, intervention, } \\
\text { punishment. }\end{array}$ \\
\hline UK & $\begin{array}{l}\text { Family } \\
\text { - Parents can influence strongly } \\
\text { - Every student needs a 'safe person' to support them } \\
\text { School } \\
\text { - Tailor school to pupil not curriculum } \\
\text { - Reduce workload so more personal and pastoral care for pupils } \\
\text { - Provide support workers } \\
\text { - Reduce class sizes } \\
\text { - Make curriculum meaningful to students } \\
\text { - Schools should be more flexible } \\
\text { - Provide 1:1 support when needed } \\
\text { - Build relationships with every student to secure their respect } \\
\text { - Provide a quiet room if students want it } \\
\text { Teachers } \\
\text { - Teachers should support every child, not just high achievers } \\
\text { - Teachers should tune into students' needs and interests } \\
\text { Community } \\
\text { - All stakeholders need to support students. } \\
\text { - Work closely with local employers }\end{array}$ \\
\hline
\end{tabular}




\section{REFLECTION AND LESSONS LEARNED}

In this report we have described the aims, the applied methodologies and research process of the study of the causes and characteristics of early school leaving, failure and school dropout in 6 European countries. We have reported the contexts for the situation of ESL in each participating country and described a set of local initiatives and practices focused in the phenomenon.

We then have examined key findings from the interviews and focus groups conducted with 291 young people and also with 36 family members, 101 education and training practitioners, 70 non-school practitioners and 9 other stakeholders. In this examination we have identified a group of factors leading to failure and ESL.

Throughout a set of life histories of 29 young people with different profiles of school experience we have analysed how those factors interconnect in the individual trajectories. In a final chapter we presented the recommendations told by youngsters, adults and stakeholders, regarding prevention of ESL, promotion of school success and dropout combat in the European countries involved in the research.

Overall, what can we conclude about the causes of early school leaving and dropping out at a local level?

Based on listening to 291 youngsters and 216 adults involved in the education dynamics in the different territories where the research was developed, it was possible to identify aspects related to 4 types of factors in the origin of failure and school leaving: individual, family, school and community. Early school leaving is a complex, multi-dimensional phenomenon with numerous causes and consequences.

With respect to individual factors, we find aspects connected with (de)motivation and inadequate attitudes, (excess of) responsibilities and financial constraints, lack of autonomy and health challenges.

Concerning family factors, the analysis has shown how dropout is result of fundamental inequities. Prevailing social conditions of these youths' impact on their academic path, especially problems related with lack of economic resources in their households, but also family structure, family relationships and family difficulties in engaging with education and school. 
School related factors are the most numerous of all factors identified by the research participants, whether young people or adults. Most often school-related characteristics are revealed as determinants of dropout over and above family-related, individual-related and other motives. The relationship between teachers and pupils, the pedagogies used and the school management approaches seem to have a significant impact on students' engagement.

Finally, community factors, connected with social contexts, sociability networks, neighbourhood characteristics, resources and institutions are less present in the narratives and reflections of the research participants. Peers' negative influence, the absence of positive role models and the prevalence of moral values that undervalue school as a mobility opportunity, are the most mentioned aspects.

In the 29 life histories of the European youngsters, we give them voices. In those, we could contact, first and foremost, with the diversity and complexity of the youngsters' trajectories. Starting from different profiles, national origins, ages and experiences, the youngsters' trajectories are complex, since a large group of factors intervene together in the production of failure (as well as of success).

Different country settings enrich the analytical perspective. It means diverse territories, therefore different educational systems, different levels of social development and of levels of school's capacity to manage and compensate the youngsters' resources deprivation.... Romanian examples show how the access to education is not assured for all youngsters. Italian histories, mostly from youngsters from the middle class with skilled parents, move the discussions to the inside of the education system. Even when the family resources are steady and assured, the massive school organization, and an aggressive school environment, trigger their harmful effects. Vulnerability and several types of abuses (from peers, parents or teachers), invisibility, isolation or demotivation in students are some of those effects.

Croatian, Portuguese and French examples show the school's incapacity to manage and compensate the youngsters' resources deprivation. They also show the difficulties youngsters have in choosing and crossing school tracks - they are multiple and mismatched with their needs and vocational orientations. These examples highlight the important role the external organizations have in providing support to youngsters and their families. Included in these organizations are social-therapeutic communities, social and school inclusion projects based in arts, and community associations. Those institutions seem to be not only contributing in a more 
significant way then schools, to the processes of vocation and development self-discovery, but also shaping a large support network that counteract the isolation so many times expressed in the collected life histories.

Local initiatives and practices to tackle ESL and promote success at school initiatives reported are very different from country to country, although overall can contribute, again in different ways (more direct or indirectly), to that aim.

In Croatia, the ESL is being publically discussed by stakeholders. There is a project underway, aimed at engaging young people and the NEET group in this effort. The methodology consists in public policies, employment and education programs.

In France, there are national strategies both preventing ESL and facilitating and supporting early leavers' return to school. There is also a project underway, which helps youngsters who want to get sustainable professional trajectories. The project is developed outside schools.

Italy reported local and territorial initiatives, which are all towards ESL in different phases of the school path (from first years, to secondary school). In common, the initiatives have the aim of motivating students (through pedagogy, extra-curricular activities, orientation, internships).

Portugal presented one national policy to promote school success and three local initiatives. All the local initiatives are situated in the community or in a close cooperation between schools and the community. The local initiatives work on the domains of self-esteem reinforcement and on motivation.

Romania reported initiatives that have different targets regarding ages (from 4 to 17), parents and students (one school for parents is mentioned) and ethnic origins (Roma or not). It is also included an initiative towards the improvement of school equipment.

All initiatives from the UK are targeted to the community and intent do tackle people and community poverty. The priorities are providing information to protect the most vulnerable people and communities and maximize the wellbeing opportunities for individuals.

How, then, can ESL and dropping out be reduced? School related factors have a large set of recommendations listed, mainly associated with strengthening teachers' training concerning relational and pedagogical issues, with the need to provide personalised and flexible supports, and with developing strong relationships between students and staff. Also, it is recommended to 
ensure there is flexibility in the curricula and in vocational offers, both aiming to meet individual needs.

There are aspects in the relational and pedagogical domain that must be improved and reinforced in the initial and continued teachers' training. It is also very important to surround young people with extra supports. In the systemic point of view, smaller schools, smaller classroom groups and reinforced teams of technical staff working in complementarity with teachers are absolutely key to customise school experience to the needs of the youngsters, to prevent disengagement of pupils and to support the development of actions that also mean compensatory solutions.

Overall, in a cross-cutting analysis of the data collected, we highlight three important aspects.

First, school path is determinant in the representation youngsters have from themselves. Repeating grades impacts very negatively on students' engagement with school, and multiple repetitions detach youngsters from their peers, discourage them and disable them for action, and do not seem to have any benefits. When the school does not give back to the youngster a good image from her/himself, and when it does not incorporate mistake as a natural part of the learning, then it generates a negative impact in all other dimensions of the youngster life; this largely determine and block future opportunities.

Secondly, as various life histories reveal, it is important to know the feelings of lack of sense in school experience many youngsters have. The artificiality, big abstractionism and not being grounded in reality, which are features that mark contemporaneous dynamics of teaching and learning, seem to be a strong obstacle to school success and to the effective involvement of youngsters on that dynamics.

Abandoning or interrupting school can be self-protecting. It is, in most cases, a rational strategy of searching an alternative activity that may give a better image of her/himself. Different from the school integration, the integration in the labour market seems, at least at first, to provide autonomy, independency or financial support (often very important in the family context), and is reality grounded. In some cases, it leads youngsters to reflect about school and to a return to the system - the education process may acquire a higher instrumental value and, finally, a sense.

If after abandoning or suspending there is no labour integration, the everyday life of the youngster turns into an emptiness, without challenges or possibilities of development and learning. Given the importance of school experience in the lives of young people, exiting this 
dynamics (often an attempt of self-protection and self-esteem rehabilitation) makes the youngsters to stay closed in the household. Or leaves them exposed to sociability spaces that are socially homogenous and tied to addicting consumptions and to informal economy. In those circumstances, community institutions could have a crucial action in finding ways to provide occupation and support.

Thirdly, and lastly, classroom is still an important and key place in school education dynamics and in the school success production. Life histories show us the centrality of the relational dimension, mainly regarding teacher and pupil. In most of them we find the narratives of teachers who built a closer relationship with the youngsters, therefore making the difference in their trajectories. However, several cases are reported in which these relationships were not good and triggered disabling vulnerabilities in the youngsters' lives.

We are generally achieving the EU targets for education in the Europe 2020 strategy, but targets and statistics hardly tell us about the long lasting effects of low achieving and dropout. Youngsters voices were clear in the life histories that were shown - low achieving is lived for a long time in silence and isolation, and drop out is very often a letting go from a very hard and violent experience within an impersonal, inflexible, complex and unarticulated school system.

The problem of early school leaving implies more than the notion of students failing to achieve academically and graduating from school. The issues may be, more precisely, not only how to better prepare them for schooling, but how to attune parents, schools and communities more to their diverse needs.

Finally, we close the report highlighting the 10 most valuable lessons learned from the research findings.

\section{Benefiting all students}

Initiatives to prevent or mitigate early school dropouts benefit all students. All students, not only those at-risk, will benefit from safe and warm learning environments in which teachers believe in students and in their ability to learn and do not give up on them. Also, a school where there is an enriched and challenging curriculum that is relevant to students' lives, the activities are inspiring, there are personalized mentoring and tutoring, and democratic decisions where students have a voice. This school is connected to a local network and is open to the community and its institutions. 


\section{Valuing education as a means of personal and social development}

The value of education is not self-evident for students struggling with poverty and low school performance. A culture of learning and understanding the value of bettering oneself needs to be fostered at an earlier stage in life. In low-income households where adults are less likely to hold high school diplomas or degrees of higher education, students lack positive academic role models. It is important to create a network of positive role models to inspire, with their stories, aspirational self-perceptions that include education paths into young people experiencing demotivation and living in difficult social environments.

\section{Transforming assessment of learning gaps and avoiding repetition}

Grade repetition should be discouraged. Our research shows the consequences of grade repetition and the academic and socio-emotional effects of retention on students. Repetition is detrimental for the students; it impacts negatively on students' attitudes towards school. The school path is determinant in the representation youngsters have from themselves. Multiple repetitions distance youngsters from their peers, discourages them and disables them for action, undermining and blocking future aspirations. It is important to raise awareness among school actors about the costs and negative impact of repetition on students. As already recommended by OECD, effective strategies to address learning gaps could alternatively include: automatic promotion, but with support; responding appropriately to continuous and comprehensive assessment during the school year; providing early, regular and timely support; or strengthening students' knowledge and metacognitive skills, among other actions and approaches. ${ }^{57}$

\section{Granting autonomy and responsibility to students}

Autonomy is put forward as ideal, and in school settings everyone is expected to be responsible and to choose his or her destiny. However, the educational systems do not give the youth all they need to acquire this autonomy. Education processes are mostly passive and over controlled by parents, teachers and adults. When students understand their role as agents over their own feelings, beliefs, thoughts and learning attitudes, they are more likely to take responsibility for their learning. To be autonomous learners, however, students need to have some actual choice and control. To help students develop the capacity to make choices for themselves, teachers need

57 OECD (2012), Equity and Quality in Education: Supporting Disadvantaged Students and Schools, OECD Publishing. 
to help students understand their learning interests, dispositions to be active and autonomous learners and capacities or strengths in various content or skill areas.

\section{Decreasing the generation gap between students and teachers}

Teaching staff continues to grow older, increasing the generation gap against students who are increasingly technologically wired. This means that teachers are increasingly unable to meet student needs and are sometimes required to teach subjects outside their expertise. Teachers are less ready for innovation and further detached from the world and culture of their students. Actions in this domain can include increasing teachers' ICT skills, improving teachers' professional development, producing appropriate software and courseware. It should also include increasing the youth culture awareness among adults, and an "intercultural" teachers' training based on contents that approaches and establishes bridges between the cultures of young people and adults.

\section{Focusing on relationships}

Unjustified authoritarian behaviour undermines students' agency and is a cause of anxiety and demotivation. Blaming and punitive approaches lead to an exacerbation of the education problems. New kinds of interaction and relationship are needed in schools. Effective changes include: establishing a caring school climate that promotes autonomy; giving positive feedback; not openly humiliating students who perform poorly; identifying and developing young people's special interests and skills. Dropout programs often focus too narrowly on changes in individual students, without considering broader peer and school influences. Educators are often concerned about the impact of student poverty and academic capability on dropout rates in their schools; however, our research shows that climate of teasing and bullying in the schools causes ESL and deserves serious consideration.

\section{Promoting innovation from a bottom up approach}

Traditional pedagogical approaches 'one-size-fits-all', class-based, emphasizing memorization or the application of simple procedures, where traditional roles prevail - teachers teach and students learn, permeable to authoritarian teaching and passive learning -, must be changed. Other pedagogical approaches are needed, such as collaborative learning, 'learning coaches', transformed learning environments able to encompass customized learning for each student, 
gaming, online laboratories, real-time assessment, blended learning, hybrid learning, flipped classrooms, among others. ${ }^{58}$ Moreover, to overcome some problems regarding teaching and learning, it is necessary to implement a dynamic of innovation. Schools cannot be left alone to face change and implement innovation; they need support of policies, but also from other actors and stakeholders. Bottom up, participatory, voluntary approaches are required to make effective change happen.

\section{Listening to young people}

Overall, this research has also showed how important it is to listening to the young people. Schools, parents and local communities should establish flexible and open, regular, communication channels and take time to understand the circumstances affecting young people at risk or who have already stopped attending school. EU Commission Thematic Working Group on early school leaving report (2013) stresses how important it is to "ensure their voices are taken into account". It's very important to include their voices in discussions about policies, programs, and community activities in this field, namely involving peers and youth itself in the designing and implementation of solutions. All the youngsters should be consulted, not only the ones having regular education paths, since young people facing challenges, low performance or at risk of ESL have rich and resourceful insights that are keys for identifying problems and solutions.

\section{Partnering for education success}

Institutions and community projects other than school are making a difference in ESL prevention and mitigation. They are contributing in a significant way to the processes of vocation and development self-discovery; giving sense to educational experience; providing personalized support and shaping large support networks that counteract student isolation. Life histories have demonstrated that students who leave school are often struggling with overwhelming life circumstances. They leave school not because of a particular event or factor, but because conditions accumulate in ways that push school further down their list of priorities. The young people affected by multiple adverse life events need early attention from peers, family members,

\footnotetext{
58 See OECD (2016), Innovating Education and Educating for Innovation: The Power of Digital Technologies and Skills, Paris, OECD Publishing; Paniagua, A. \& D. Istance (2018), Teachers as Designers of Learning Environments: The Importance of Innovative Pedagogies, Educational Research and Innovation, Paris, OECD Publishing; or Scott, C. L. (2015), The Futures of Learning 3: What kind of pedagogies for the 21st century? UNESCO Education Research and Foresight, Paris.
} 
school professionals, youth workers, neighbours, and other adults and stakeholders. This attention could make a difference and prevent dropout. Genuine inter-professional collaboration is needed for early school leaving prevention, namely involving multiple institutions and multidisciplinary teams of care workers, counsellors, nurses, speech and language therapists, social workers, occupational therapists, mediators, mentors, among others. Efforts are required to support inter-professional collaborations and overcome resistance.

\section{Easing the return to education}

Young people who leave high school also need to have, and be informed about, approaches of reintegration into education. For the young people it seems easier to leave school than to reintegrate. The examination of the existent formal policies related to re-entry education deserves stronger attention. 


\section{AnNEXES}

Annex 1 - Template for semi-structured, in-depth interview with young people Annex 2 - 2 Template for focus group of young people Annex 3 - Template for focus group of actors and stakeholders Annex 4 - Output 1 Final Report Template 


\section{Annex 1 Template for semi-structured, in-depth interview with young people}

Interview notes [to be completed by the interviewer]

Date: Time: Location:

Methodological notes

[Any interruptions? Reasons for interruptions. How was the schedule? Attitude? Quality of interaction?]

Name:

Country of birth:

Profile [student; NEET; ESL...]:
Date of birth:

Duration [of the interview]

\section{Questions for all}

- How would you describe your present school/the last school you attended? Is it a good school? Why? Do you feel you belong/belonged there?

- Tell me about your pre-school/elementary/ high school experience. What are you most positive and most negative memories?

- How did you get on with your schoolmates? And your teachers?

- Have you any special teachers? Describe what you liked most about them.

- Describe your grades while in pre-school/elementary/ high school (e.g., good, average, poor).

- Were you ever disciplined or suspended school while in elementary/ high school? If so, why?

- Describe your attendance (e.g., good, average, poor). Were you often absent? Why?

- Were you ever held back in a particular grade? Which? When? Why? How did that make you feel?

- Have you ever changed schools or courses? When? Why? What was the impact of these changes? Positive? Negative?

- Do you find learning useful? Why?

- What are your future education plans? How far do you want to go?

- Did you want the same five years ago? Have your aspirations changed? Why?

- What are your main interests in everyday life? What do you like to do most?

- What are you most proud of?

- How many people live in your house? Do you have siblings? [or grandparents, parents and siblings]

- What level of education did they reach?

- $\quad$ Do they work? If so, what is their main job? If they not, please describe their last main job.

- Are they retired? Unemployed? Have a long-term illness? Disabled? Students?

- Did you ever move house during your schooling? How many times? In which grade?

- How do/did your parents get involved in your education? Do they usually go to school meetings? And other activities in school? How did your parents communicate with teachers? When?

- What do/did your parents do at home to encourage you and help you study?

- If you had low performance at school, how did your parents react?

- Do you have any responsibilities at home? What about your siblings?

- Describe your daily routine on a normal school day.

- What is your relationship with your parents like?

- What is the highest level of education that your parents would ideally like you to achieve? 
- What is the highest level of education that your parents realistically expect you to achieve?

- Describe a regular weekend. What do you usually do? With whom?

- Have you ever done volunteer work?

- Have you ever been involved in civic, religious, recreational musical or sports activities?

- How did you reconcile these activities with school?

- Who are your best friends? Where did you meet them? (school, near home, other places)

- Describe the grades that your closest friends got at school (e.g., good, average, poor)

- Did you have friends who dropped out of school? What are they doing now? Are they working?

- Describe your closest friends' aspirations.

- Have you any work experience? Describe it (motivation, duration, field, how you spent your pay, feelings towards it)

- What would your dream job be? What kind of job do you realistically think you will get?

- Do the school courses you are taking prepare you for that job?

- What do you think could be done to prevent ESL?

- What do you think could be done to convince students to remain in school? What do you think might prevent someone from dropping out?

- What do you think could be done to convince students to go back to school after a period of absence?

- Who should be involved in these solutions?

- Is there anything else you would like to say?

\section{Additional questions to students at risk of becoming early school leavers}

- What factors are causing you to consider leaving school early?

- What are your main problems? (difficult subjects; relationship with school friends, lack of interest in studying...)

- What/who would help convince you to stay at school?

- Do you think that a decision to drop out of school or leave your course might affect your earnings for the rest of your life?

- How does the school organisation try to meet your needs?

- Did you receive any support from the school? (e.g. remedial classes, tutoring, psychological support ...)

- Do you feel that attending school regularly would increase your chances of getting a good job?

- Do you feel teachers are interested in your decisions and want to help you achieve what you want in life?

\section{Additional questions to ESL youngsters}

- Was dropping out of school a good or bad decision for you? Explain why.

- Why did you drop out of school? What were your main reasons?

- How long did it take you to reach this decision?

- How old were you when you dropped out?

- What was the most critical moment in the process of dropping out?

- Did your decision have the effect you thought it would?

- When you think back, describe any specific events that led to your dropping out of school.

- Would you do anything differently if you had the chance?

- What do you think could have prevented you from dropping out?

- How do you feel the decision to drop out of education or leave your course will affect your earnings in later life?

- Had anyone in your family ever dropped out? Who and why?

- How did your parents react to your quitting school?

- How did your brothers and sisters react to your quitting school?

- How did your teachers react when they learned that you were dropping out? 
- How did the school organisation try to meet your needs?

- Apart from your teachers did you have contacts with other education experts inside or outside the school?

- What were your relationships with your school friends like?

- How did your school friends react when they found out that you were dropping out?

- Did you have friends who also dropped out of school?

- What are they doing now? Are they working? Are they doing any kind of training?

- How did your friends react to your quitting school?

\section{Additional questions to Youngsters that re-engaged in schooling}

- Was dropping out of school a good or a bad decision for you? Explain why.

- Why did you drop out of school? What were your main reasons?

- How long did it take you to reach this decision?

- How old were you when you dropped out?

- What was the most critical moment in the process of dropping out?

- Did your decision have the effect you thought it would?

- When you think back, describe any specific events that led to your dropping out.

- Would you do anything differently if you had the chance?

- What do you think could have prevented you from dropping out?

- How do you feel the decision to drop out of education or leave your course will affect you in later life?

- How did your parents react to you quitting school?

- How did your brothers and sisters react to you quitting school?

- Had anyone in your family ever dropped out? Who and why?

- How have your teachers helped you?

- How does the school organisation meet your needs?

- Apart from your teachers, does anyone else help you at school?

- What are your relationships with your school friends like?

- Did anyone encourage you to re-engage in school? Who? Why?

- When did you decide to go back?

- Did any person or event speed up the process?

- Did going back to school change anything in your life? What? 


\section{Annex 2 Template for focus group of young people}

Focus group notes [to be completed by the facilitator]

Date: Time: Location:

Methodological notes

[Any interruptions? Reasons for interruptions. How was the schedule? Attitude? Quality of interaction?]

Number of participants Duration [of the focus group]

Profile of the participants [student representatives, student; NEET; ESL...]:

\section{Questions}

- What do you think are the main reasons why students leave school?

- Does family have anything to do with it?

- What kind of family resources and attitudes are needed to keep students at school?

- What do you think parents could do to improve students' success?

- Can certain types of school lead more easily to ESL?

- Can certain types of relationship with teachers lead to ESL? How can it be prevented?

- What do you think are the main characteristics of a remarkable teacher? And the opposite?

- In your opinion, what is needed to be a good student?

- Why do students miss school? How can it be prevented?

- How do you think schools can increase student's sense of belonging?

- Can certain relationship with schoolmates lead to dropout student dropping out? How can it be prevented?

- What do you think could be done in schools to prevent ESL?

- Do you think young people's friendships can influence school results? How?

- Do you think community organisations can help prevent ESL? How? Please describe some specific projects/initiatives you know of.

- Is dropping out of school a good or bad decision? Explain.

- Do you know any ESL youngsters? Can you describe why they dropped out? What do think was the most critical moment in the process of dropping out?

- How do you feel the decision to drop out of education will affect youngsters in later life?

- What do you think could be done to prevent ESL?

- What do you think could be done to convince students to remain in school? - What do you think could prevent someone from dropping out?

- What do you think could be done to convince students to re-engage with school after a period of absence?

- Who should be involved in these solutions?

- Is there anything else you would like to say? 


\title{
Annex 3 Template for focus group of actors and stakeholders
}

\author{
Focus group notes [to be completed by the facilitator] \\ Date: Time: Location: \\ Methodological notes \\ [Any interruptions? Reasons for interruptions, How was the schedule? Attitude? Quality of interaction?]
}

\begin{abstract}
Number of participants Duration [of the focus group]
Participants' profile [head teachers; representatives of vocational training institutions; teachers; public officials, local government officials; leaders of associations; researchers; youth workers, family members ...]:
\end{abstract}

\section{Questions for all}

- Are home situations and family contexts important in explaining ESL? Why? Give some examples.

- What are the impacts of ESL on families?

- What do you think could be done with families to prevent ESL?

- What are the main challenges when working with ESL students' families?

- Is parents' emotional and affective support important in preventing ESL?

- What is the outlook for ESL in this region? Why?

- What are the main reasons for ESL in this region?

- What are the main actors and institutions involved in ESL prevention? Are any other institutions needed?

- What initiatives have been tested and with what results?

- What are the impacts of ESL on the region?

- What do think are the main factors that might increase students' success?

- What are the main school factors leading to ESL?

- What are the impacts of ESL on schools?

- Who are the main school actors involved in ESL prevention? Are any other actors needed?

- What do you think could be done in schools to prevent ESL?

- What are the impacts of ESL on the community?

- What are the main community actors involved in ESL prevention? Are any other actors needed?

- What do you think could be done in the community to prevent ESL?

- What do you think could be done individually to prevent ESL?

- What do you think could be done to convince students to stay at school? And to re-engage with school after a period of absence?

- What do you think might prevent someone from dropping out?

- What are the best practices and initiatives? And the worst?

- Who should be involved in these solutions?

- Is there anything else you would like to say?

\section{Additional questions to education and training practitioners}


- What do you think are the main ways to improve students' success?

- How has school success been promoted in school? Please give some examples.

- How do you identify a young person in danger of dropping out? Give some examples.

- What do you think are the main strategies currently used in schools to identify students at risk of ESL? Do they work well? What has not worked and why?

\section{Additional questions family members (of ESL or disengaged students)}

- Do you think school is important? How important is school in young people's lives? Does school prepare young people for life?

- What do you think of your child's school? Has it got better or worse?

- What were the signs suggesting your child was disengaging from school?

- Who did you talk to at the school about your child's disengagement? What did the school do?

- What more could the school have done to help the situation?

- Did any external organisations apart from the school help you with the situation? 
Annex 4 Output 1 Final Report Template (next page) 


\title{
Erasmus+
}

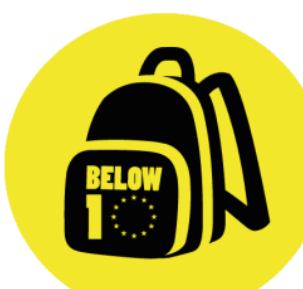

\author{
BELOW 10
}

\section{Output 1 Final Report Template}

Country/region:

Partner:

Please indicate the name of the territories/regions where research was carried out:

Please indicate the period during which the investigation was carried out:

Date of the report:

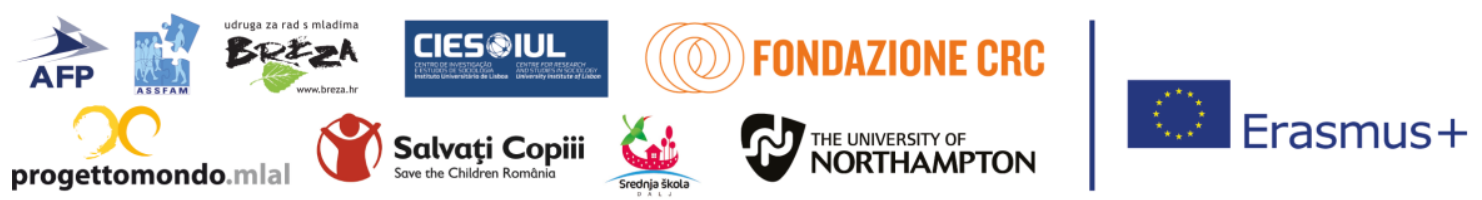


A1. Early school leaving and early leavers - national and local official definitions

A2. Importance of ESL prevention and student re-engagement on national and local education agenda

A3. Recent national ESL statistics (national and local)

A.4 Consulted reports, documents and studies (references list, including Author name, date of publication, title, source, city, publisher...)

Example

Downes, P. (2013). Developing a Framework and Agenda for Students' Voices in the School System across Europe: from diametric to concentric relational spaces for early school leaving prevention. European Journal of Education, 48(3), pp. 346-362. 
Table A5. National and local policies and initiatives on ESL prevention and student re-engagement (maximum 3 initiatives)

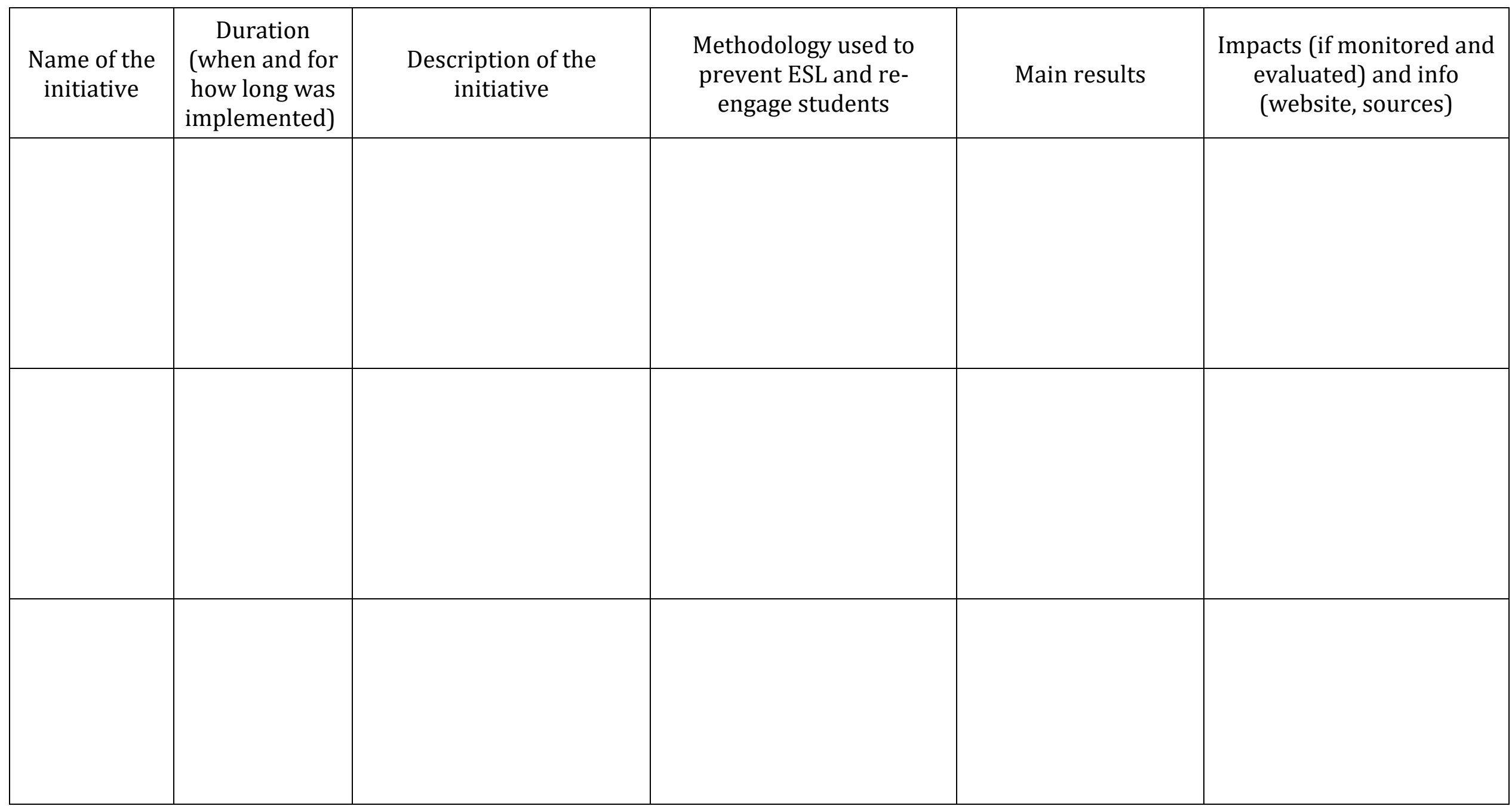


a) Please fill the complementary excel file describing each adult that was involved in the research.

b) According with the data collected from interviews and focus groups with adults/stakeholders, please list (use a bulleted list):

B1. Individual factors explaining disengagement and ESL

B2. Family factors explaining disengagement and ESL

B3. School factors explaining disengagement and ESL

B.4 Community factors explaining disengagement and ESL 


\section{B.5 Significant quotes}

\section{Example 59}

"Those who dropout, many do it because of economic factors, yes. Although education is free, is never completely free and they then end up having to buy the public transport pass, meals and although most subjects do not have manuals, they will also have to buy the copies. So is never completely free." [Teacher, Portugal]
1. “...." [stakeholder category, country]
2. “....." [stakeholder category, country]
3. “...." [stakeholder category, country]
4. $\quad \ldots$

B6. Recommendations of adults/stakeholders on actions to reduce ESL

\footnotetext{
59 Please use one of the following categories when identifying the stakeholder/adult: adults who have been ESL; cultural, sports and social association worker or volunteer; educational assistant; family member; head of association; head teacher; local employment officer; local government official; other non-school practitioner; other school practitioner; other; parents' association member; public official; researcher; school counsellor; school mentor/tutor; social worker; teacher; trainer; vocational training institutions representative; youth worker or volunteer.
} 
a) Please fill the complementary excel file describing each young person that was involved in the research.

b) According with the data collected from interviews and focus groups with young people, please list (use a bulleted list):

C1. Individual factors explaining disengagement and ESL

C2. Family factors explaining disengagement and ESL

C3. School factors explaining disengagement and ESL

C4. Community factors explaining disengagement and ESL 


\section{C5. Significant quotes}

\section{Example 60}

"I always had the bad luck to stay in the worst classes. Basically it was where the ruffians were at the time. That influenced everyone, and then they ended up influencing me too." [João, 18, employed Early School Leaver, Portugal]

1. “....." [fictitious name, age, profile, country]

2. “....” [fictitious name, age, profile]

3. “...." [fictitious name, age, profile]

4. $\quad \ldots$

C6. Recommendations of young people on actions to reduce ESL

\footnotetext{
${ }^{60}$ Please use the following categories/profiles when identifying the young person: early school leaver not in employment, education or training (NEET); employed Early School Leaver; young person at high risk of early school leaving; young person who have returned to school or training after ESL or suspending; young person enrolled in education or vocational training; other.
} 


\section{Box no 1}

\section{Fictitious name:}

Profile (early school leaver not in employment, education or training (NEET); employed early school leaver; young person at high risk of early school leaving; young person who have returned to school or training after ESL or suspending; young person enrolled in education or vocational training):

\section{Title of the life history:}

Tell the youngster's history. Support the narrative with small direct quotes when relevant. Keep it as short as possible without forfeiting value or uniqueness. Please see example given during Northampton meeting. Please use the following structure:

Who is the youngster?

What he/she currently does and what kind of person are she/he?

How was the school path?

In what she/he context?

Future aspirations

Recommendations - How can school be better?

Source: Life history interview conducted in [region], [country], [date] 


\section{Box no 2}

\section{Fictitious name:}

Profile ((early school leaver not in employment, education or training (NEET); employed early school leaver; young person at high risk of early school leaving; young person who have returned to school or training after ESL or suspending; young person enrolled in education or vocational training)):

\section{Title of the life history:}

Tell the youngster's history. Support the narrative with small direct quotes when relevant. Keep it as short as possible without forfeiting value or uniqueness. Please see example given during Northampton meeting. Please use the following structure:

Who is the youngster?

What he/she currently does and what kind of person are she/he?

How was the school path?

In what she/he context?

Future aspirations

Recommendations - How can school be better?

Source: Life history interview conducted in [region], [country], [date] 


\section{Box no 3}

\section{Fictitious name:}

Profile (early school leaver not in employment, education or training (NEET); employed early school leaver; young person at high risk of early school leaving; young person who have returned to school or training after ESL or suspending; young person enrolled in education or vocational training):

\section{Title of the life history:}

Tell the youngster's history. Support the narrative with small direct quotes when relevant. Keep it as short as possible without forfeiting value or uniqueness. Please see example given during Northampton meeting. Please use the following structure:

Who is the youngster?

What he/she currently does and what kind of person are she/he?

How was the school path?

In what she/he context?

Future aspirations

Recommendations - How can school be better?

Source: Life history interview conducted in [region], [country], [date] 


\section{Box no 4}

\section{Fictitious name:}

Profile (early school leaver not in employment, education or training (NEET); employed early school leaver; young person at high risk of early school leaving; young person who have returned to school or training after ESL or suspending; young person enrolled in education or vocational training):

\section{Title of the life history:}

Tell the youngster's history. Support the narrative with small direct quotes when relevant. Keep it as short as possible without forfeiting value or uniqueness. Please see example given during Northampton meeting. Please use the following structure:

Who is the youngster?

What he/she currently does and what kind of person are she/he?

How was the school path?

In what she/he context?

Future aspirations

Recommendations - How can school be better?

Source: Life history interview conducted in [region], [country], [date] 


\section{Box no 5}

\section{Fictitious name:}

Profile (early school leaver not in employment, education or training (NEET); employed early school leaver; young person at high risk of early school leaving; young person who have returned to school or training after ESL or suspending; young person enrolled in education or vocational training):

\section{Title of the life history:}

Tell the youngster's history. Support the narrative with small direct quotes when relevant. Keep it as short as possible without forfeiting value or uniqueness. Please see example given during Northampton meeting. Please use the following structure:

Who is the youngster?

What he/she currently does and what kind of person are she/he?

How was the school path?

In what she/he context?

Future aspirations

Recommendations - How can school be better?

Source: Life history interview conducted in [region], [country], [date] 